Prepared in cooperation with the National Park Service

\title{
Review of Available Water-Quality Data for the Southern Colorado Plateau Network and Characterization of Water Quality in Five Selected Park Units in Arizona, Colorado, New Mexico, and Utah, 1925 to 2004
}

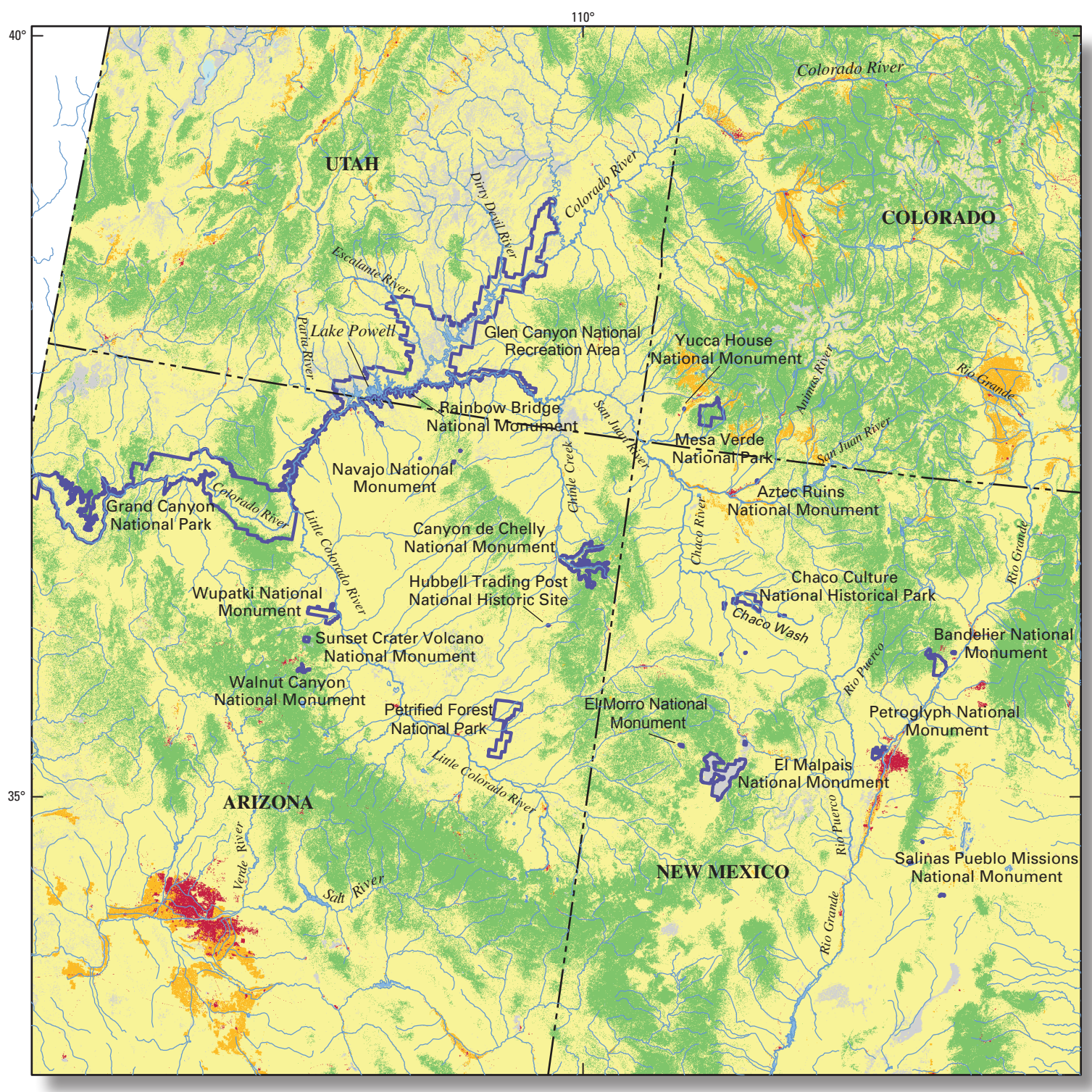

Scientific Investigations Report 2008-5130 



\section{Review of Available Water-Quality Data for the Southern Colorado Plateau Network and Characterization of Water Quality in Five Selected Park Units in Arizona, Colorado, New Mexico, and Utah, 1925 to 2004}

By Juliane B. Brown

Prepared in cooperation with the National Park Service

Scientific Investigations Report 2008-5130 


\section{U.S. Department of the Interior DIRK KEMPTHORNE, Secretary}

\section{U.S. Geological Survey \\ Mark D. Myers, Director}

\section{U.S. Geological Survey, Reston, Virginia: 2008}

For product and ordering information:

World Wide Web: http://www.usgs.gov/pubprod

Telephone: 1-888-ASK-USGS

For more information on the USGS - the Federal source for science about the Earth, its natural and living resources, natural hazards, and the environment:

World Wide Web: http://www.usgs.gov

Telephone: 1-888-ASK-USGS

Any use of trade, product, or firm names is for descriptive purposes only and does not imply endorsement by the U.S. Government.

Although this report is in the public domain, permission must be secured from the individual copyright owners to reproduce any copyrighted materials contained within this report.

Suggested citation:

Brown, J.B., 2008, Review of available water-quality data for the Southern Colorado Plateau Network and characterization of water quality in five selected park units in Arizona, Colorado, New Mexico, and Utah, 1925 to 2004: U.S. Geological Survey Scientific Investigations Report 2008-5130, 118 p. 


\section{Contents}

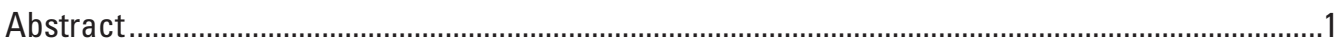

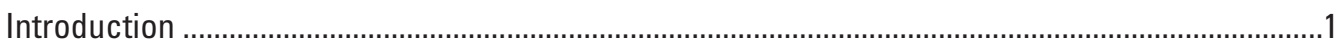

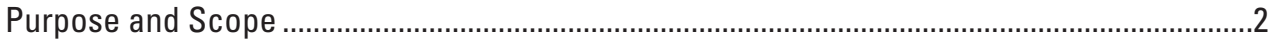

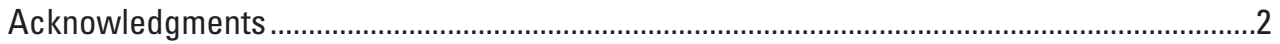

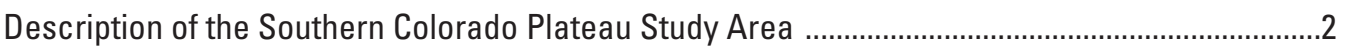

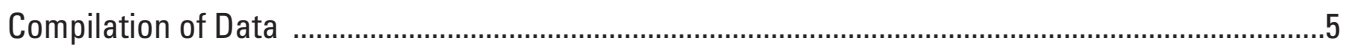

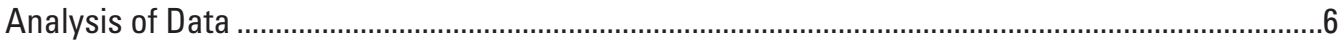

Computation of Descriptive Statistical Measures ………………………………….............

Comparison to State Water-Quality Standards...........................................................................

Overview of Water Quality and Southern Colorado Plateau Network Park Units ...............................7

Available Water-Quality Data for Parks .................................................................................

Water-Quality Issues Identified by Parks ………………........................................................

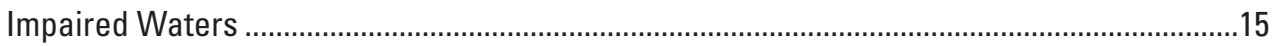

Characterization of Water Quality for Five Southern Colorado Plateau Network Park Units ........15

Bandelier National Monument, New Mexico …………….....................................................16

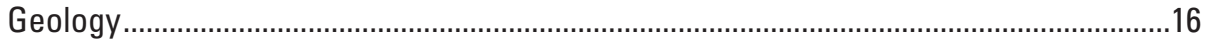

Water Resources ..................................................................................................

Available Water-Quality Data .......................................................................................

Characterization of Water Quality...................................................................................

Surface-Water Quality .............................................................................................

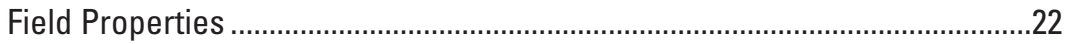

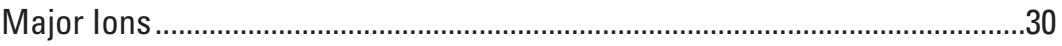

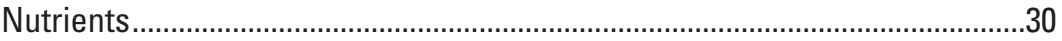

Other Constituents .......................................................................................

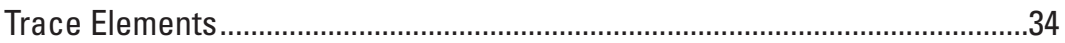

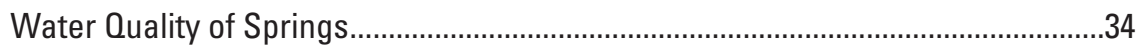

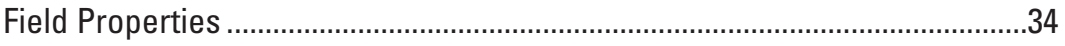

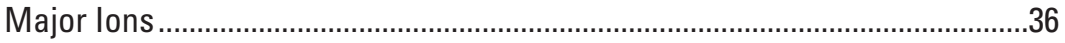

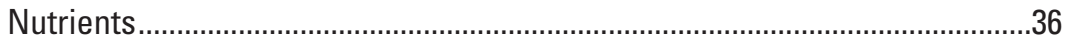

Trace Elements, Radionuclides, and Volatile Organic Compounds ................37

Summary of Surface-Water and Springs Characterization and Considerations

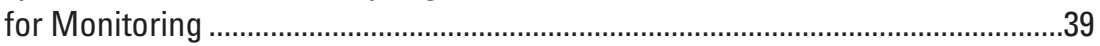

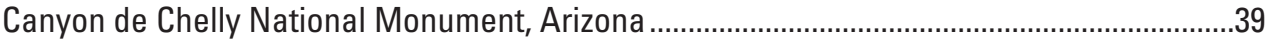

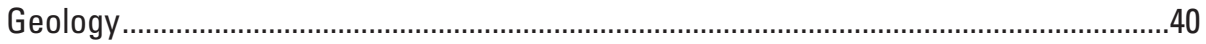

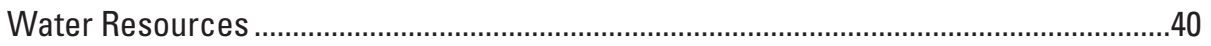

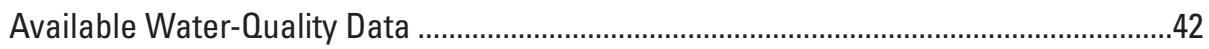

Characterization of Water Quality..............................................................................

Field Properties ................................................................................................

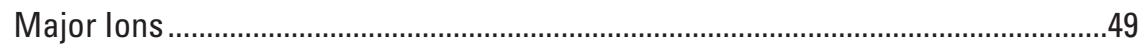

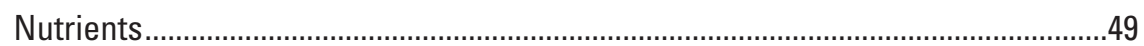

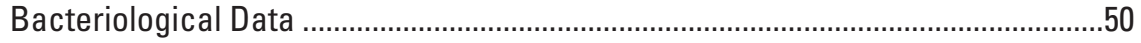

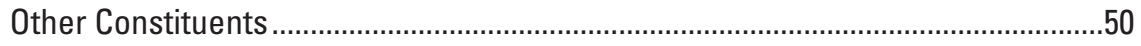

Trace Elements .................................................................................................... 
Summary of Surface-Water Characterization and Considerations for Monitoring........51

Chaco Culture National Historical Park, New Mexico ........................................................51

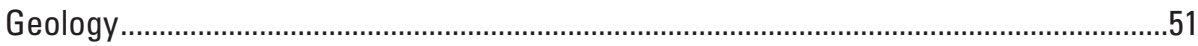

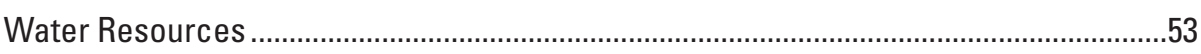

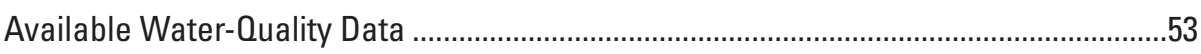

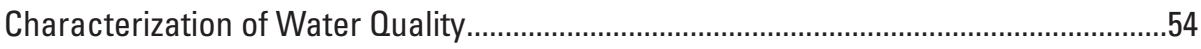

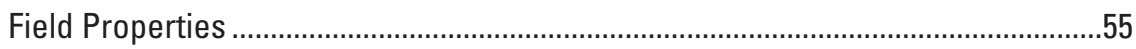

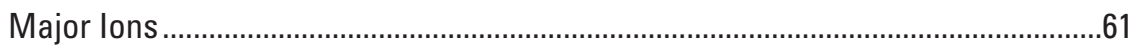

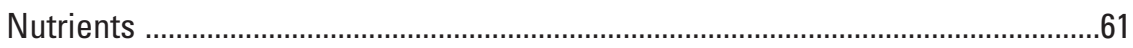

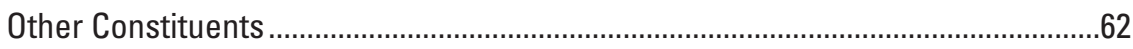

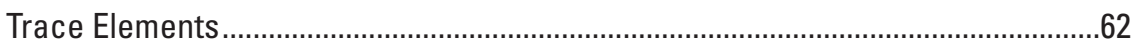

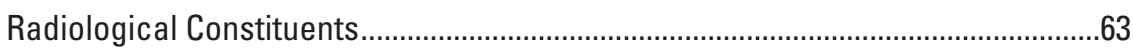

Summary of Surface-Water Characterization and Considerations for Monitoring........63

Glen Canyon National Recreation Area, Arizona and Utah .....................................................63

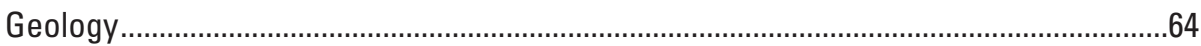

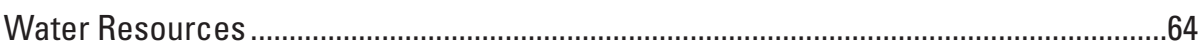

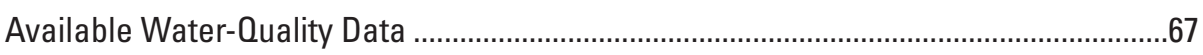

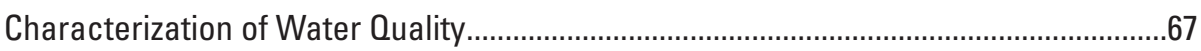

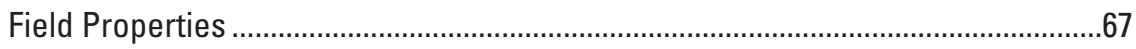

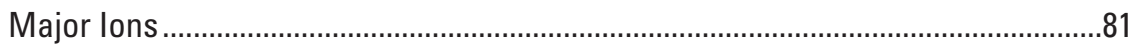

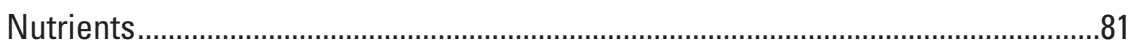

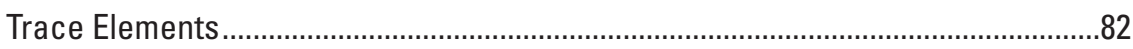

Organic, Pesticide, and Wastewater Compounds ..................................................84

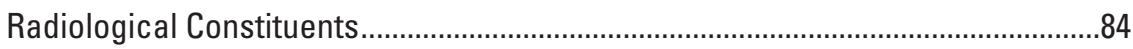

Summary of Surface-Water Characterization and Considerations for Monitoring ........84

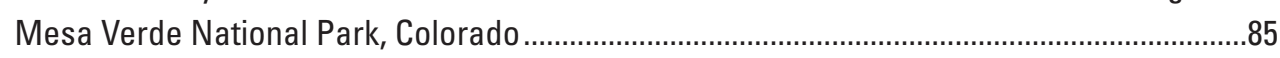

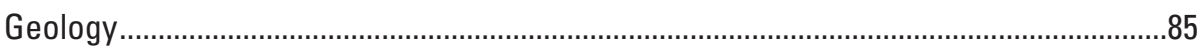

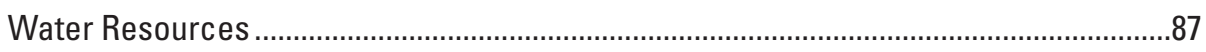

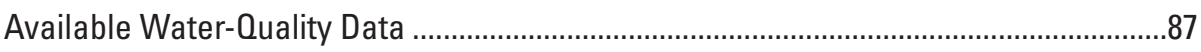

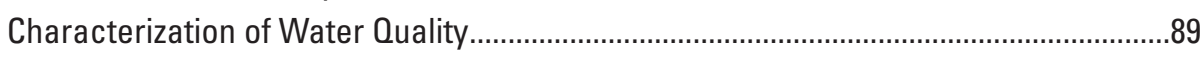

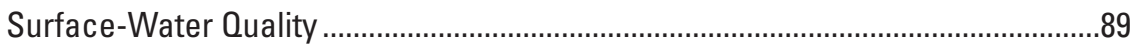

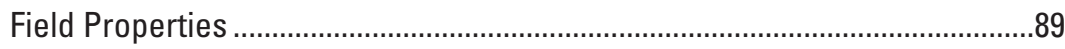

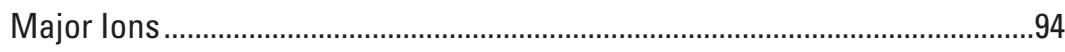

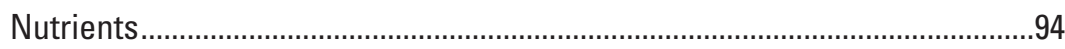

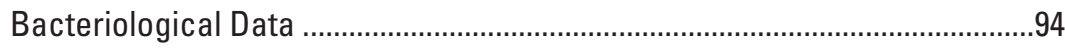

Trace Elements ..........................................................................................

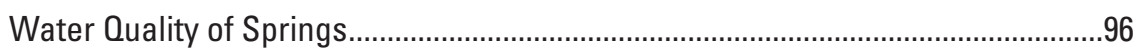

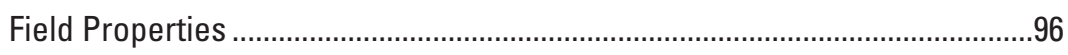

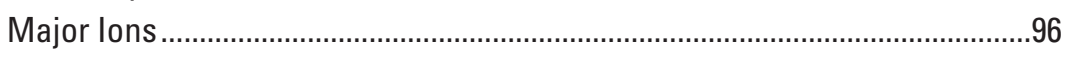

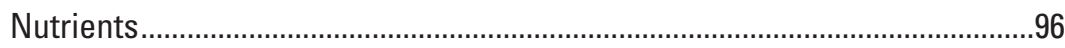

Bacteriological Data .................................................................................98

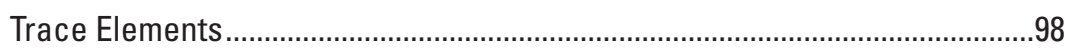

Summary of Surface-Water and Springs Characterization and Considerations for

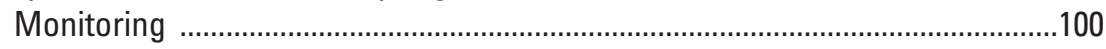

Synthesis of Surface-Water Characterization and Implications for Future Water-Quality

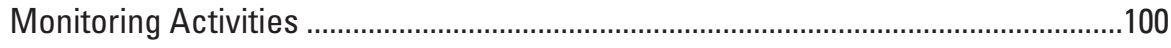


References Cited.

Appendix. Overview of Water-Quality Properties of Interest to Southern Colorado Plateau Net-

work Park Units

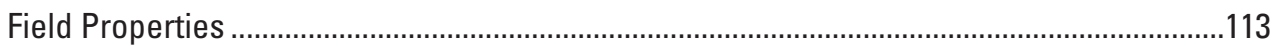

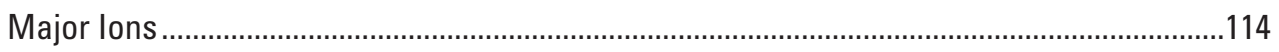

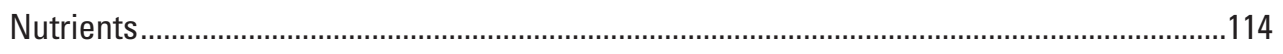

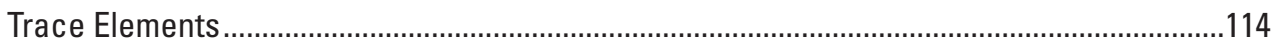

Solids (Suspended and Dissolved) .................................................................................115

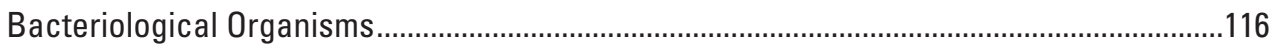

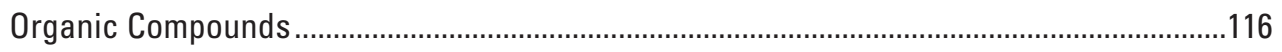

Radiological Constituents...........................................................................................116

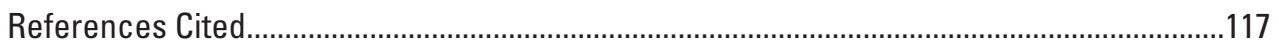

\section{Figures}

1. Map showing Southern Colorado Plateau Network showing park boundaries, land cover, and principal surface-water bodies

2. Map showing Bandelier National Monument, New Mexico, and locations of water-quality sampling sites

3. Graph showing water sample counts, number of sites, and period of record for Alamo Creek, Capulin Creek, and the Rito de los Frijoles in Bandelier National Monument, New Mexico, 1957 to 2001

4. Graph showing water sample counts and period of record of Apache, Basalt, Frijoles, and Turkey Springs in Bandelier National Monument, New Mexico, 1951 to 1998

5. Piper diagram showing water types for Alamo Creek, Capulin Creek, and the Rito de los Frijoles in Bandelier National Monument, New Mexico, 1957 to 2001..........31

6. Piper diagram showing water types for Basalt, Turkey, Apache, and Frijoles Springs in Bandelier National Monument, New Mexico, 1965 to 1978.

7. Map showing Canyon de Chelly National Monument, Arizona, and locations of water-quality sampling sites.

8. Graph showing total number of stream and reservoir samples collected for bacteriological data, trace elements, nutrients, and field properties, number of sites, and period of record, Canyon de Chelly National Monument, Arizona, 1967 to 2003

9. Piper diagram showing water types for headwater creeks, headwater lakes, and Chinle Wash, Canyon de Chelly National Monument, Arizona, 1967 to 2003.

10. Map showing Chaco Culture National Historical Park, New Mexico, and locations of water-quality sampling sites.

11. Graph showing total number of stream samples (and sites) collected for field properties, nutrients, trace elements, and radiological constituents, Chaco Culture National Historical Park, New Mexico, 1976 to 1983.

12. Piper diagram showing water types of contributing washes (Escavada, Fajada, and Gallo Washes), Chaco Wash and the Chaco River, and Kim-me-ni-oli Wash, Chaco Culture National Historical Park, New Mexico, 1976 to 1983

13. Map showing Glen Canyon National Recreation Area, Arizona and Utah, and locations of water-quality sampling sites. 
14. Graph showing total number of sites and samples for field properties and major ions, nutrients, and trace elements collected from selected streams, excluding the Colorado and San Juan Rivers, and unnamed waters, flowing into and within Glen Canyon National Recreation Area, Arizona and Utah, 1947 to 2003.

15. Graph showing total number of water samples collected from the Dirty Devil, Escalante, and Paria Rivers for field properties, major ions, nutrients, and trace elements, Glen Canyon National Recreation Area, Arizona and Utah, 1947 to 2003........72

16. Piper diagram showing water types of the Dirty Devil, Escalante, and Paria Rivers, Glen Canyon National Recreation Area, Arizona and Utah, 1947 to 2003.

17. Map showing Mesa Verde National Park, Colorado, and locations of water-quality sampling sites

18. Piper diagram showing water types for selected upstream from and inpark Mancos River sites, Mesa Verde National Park, Colorado, 1975 to 1998. . .95

19. Piper diagram showing water types for the four springs with five or more major ion samples in Mesa Verde National Park, Colorado, 1977 to 1998

\section{Tables}

1. National Park Service units in the Southern Colorado Plateau Network, including acreage, State, and visitation statistics

2. Selected aquatic-life stream-segment numeric water-quality standards for selected field properties and constituents for Southern Colorado Plateau parks

3. Numbers of streams, springs, lakes (includes reservoirs, ponds or pools), and ground-water sites and water samples collected within Southern Colorado Plateau Network park boundaries and period of record, 1925 to 2003

4. Number of water samples by site type and constituent class for sites within Southern Colorado Park Network park boundaries, 1925 to 2003

5. Summary of water-quality stressors by park identified by Southern Colorado Plateau Network park personnel during Phase I and Phase II of the Inventory and Monitoring Program activities

6. Stream and spring sites with water-quality data in or upstream from Bandelier National Monument, New Mexico, 1951 to 2001

7. Statistical summary of water-quality data and exceedances of water-quality standards at selected Alamo Creek sampling sites located in and upstream from Bandelier National Monument, New Mexico, 1977 to 2001

8. Statistical summary of water-quality data and exceedances of water-quality standards at selected Capulin Creek sampling sites located in Bandelier National Monument, New Mexico, 1977 to 2001

9. Statistical summary of water-quality data and exceedances of water-quality standards in selected Rito de los Frijoles (Upper and Lower Frijoles Creek) sampling sites located in Bandelier National Monument, New Mexico, 1957 to 2001

10. Organic compounds and pesticides detected in bed-sediment and fish tissue samples from November 9, 1992, sampling event at site 308, Frijoles Creek below Frijoles Falls, in the Lower Rito de los Frijoles in Bandelier National Monument, New Mexico. 
11. Statistical summary of water-quality data and exceedances of water-quality standards in Apache, Basalt, Frijoles, and Turkey Springs in Bandelier National Monument, New Mexico, 1951 to 1998

12. Summary of trace-element and radionuclide values greater than the censoring level for Basalt Spring from August 14, 1997, sample in Bandelier National Monument, New Mexico

13. Stream and lake sites with water-quality data in, near, or upstream from Canyon de Chelly National Monument, Arizona, 1967 to 2003

14. Statistical summary of water-quality data and exceedances of water-quality standards in selected surface-water sampling sites located in, near, and upstream from Canyon de Chelly National Monument, Arizona, 1967 to 2003

15. Stream sites with water-quality data in, upstream from, and downstream from Chaco Culture National Historical Park, New Mexico, 1976 to 1983

16. Statistical summary of water-quality data and exceedances of water-quality standards at selected stream sampling sites located in, upstream from, and at the downstream boundary of Chaco Culture National Historical Park, New Mexico, 1976 to 1983

17. Summary of temperature, precipitation, and snowfall records from six climate stations near Glen Canyon National Recreation Area, Arizona and Utah, 1901 to 2006

18. Summary of real-time streamflow gages of major perennial rivers flowing into and out of Glen Canyon National Recreation Area, Arizona and Utah 66

19. Selected stream sites with water-quality data in or upstream from Glen Canyon National Recreation Area, Arizona and Utah, 1947 to 2003

20. Statistical summary of water-quality data and exceedances of water-quality standards for selected stream sampling sites in the Dirty Devil, Escalante, and Paria Rivers located in and upstream from Glen Canyon National Recreation Area, Arizona and Utah, 1947 to 2003.

21. Statistical summary of water-quality data and aquatic-life or secondarycontact recreation exceedances for evaluated tributaries that flow into the Escalante River or Lake Powell, Glen Canyon National Recreation Area, Utah, 1979 to 2003

22. Pesticide compounds with values above censoring levels from samples collected in 1985, 1986, and 2002 in the Escalante and Paria Rivers, Glen Canyon National Recreation Area, Arizona and Utah

23. Mancos River and spring sites with water-quality data in, upstream from, and downstream from Mesa Verde National Park, Colorado, 1971 to 2002

24. Period of record and sample counts for sites with water-quality data on the Mancos River in and near Mesa Verde National Park, Colorado, 1971 to 2002

25. Period of record and sample counts for springs in Mesa Verde National Park, Colorado, with water-quality data, 1977 to 1998

26. Statistical summary of water-quality data and exceedances of water-quality standards in selected Mancos River sites located directly upstream from or within Mesa Verde National Park, Colorado, 1975 to 1998

27. Statistical summary of water-quality data and exceedances of water-quality standards for selected springs in Mesa Verde National Park, Colorado, 1977 to 1998

28. Summary of water-quality standard exceedances by park for stream sites for five Southern Colorado Park Network park units, Arizona, Colorado, New Mexico, and Utah, 1988-2003 


\section{Conversion Factors, Abbreviations of Units of Measure, and Horizonal and Vertical Datum}

Inch/Pound to SI

\begin{tabular}{|c|c|c|}
\hline Multiply & By & To obtain \\
\hline \multicolumn{3}{|c|}{ Length } \\
\hline inch & 2.54 & centimeter $(\mathrm{cm})$ \\
\hline inch & 25.4 & millimeter $(\mathrm{mm})$ \\
\hline foot $(\mathrm{ft})$ & 0.3048 & meter $(\mathrm{m})$ \\
\hline mile (mi) & 1.609 & kilometer $(\mathrm{km})$ \\
\hline \multicolumn{3}{|c|}{ Area } \\
\hline acre & 4,047 & square meter $\left(\mathrm{m}^{2}\right)$ \\
\hline acre & 0.004047 & square kilometer $\left(\mathrm{km}^{2}\right)$ \\
\hline hectare (ha) & 2.471 & acre \\
\hline square mile $\left(\mathrm{mi}^{2}\right)$ & 259.0 & hectare (ha) \\
\hline \multicolumn{3}{|c|}{ Volume } \\
\hline acre-foot (acre-ft) & 1,233 & cubic meter $\left(\mathrm{m}^{3}\right)$ \\
\hline \multicolumn{3}{|c|}{ Concentration Unit } \\
\hline micrograms per kilogram $(\mu \mathrm{g} / \mathrm{Kg})$ & 1 & parts per billion (ppb) \\
\hline micrograms per liter $(\mu \mathrm{g} / \mathrm{L})$ & 1 & parts per billion (ppb) \\
\hline$\underline{\text { milligrams per liter }(\mathrm{mg} / \mathrm{L})}$ & 1 & parts per million (ppm) \\
\hline \multicolumn{3}{|c|}{ Flow rate } \\
\hline foot per year (ft/yr) & 0.3048 & meter per year (m/yr) \\
\hline cubic foot per second $\left(\mathrm{ft}^{3} / \mathrm{s}\right)$ & 0.02832 & cubic meter per second $\left(\mathrm{m}^{3} / \mathrm{s}\right)$ \\
\hline cubic foot per second $\left(\mathrm{ft}^{3} / \mathrm{s}\right)$ & 448.83 & gallons per minute (gpm) \\
\hline \multicolumn{3}{|c|}{ Radioactivity } \\
\hline picocurie per liter $(\mathrm{pCi} / \mathrm{L})$ & 200 & millirem per year $(\mathrm{mrem} / \mathrm{yr})$ \\
\hline
\end{tabular}

Temperature in degrees Celsius $\left({ }^{\circ} \mathrm{C}\right)$ may be converted to degrees Fahrenheit $\left({ }^{\circ} \mathrm{F}\right)$ as follows:

$$
{ }^{\circ} \mathrm{F}=\left(1.8 \times{ }^{\circ} \mathrm{C}\right)+32
$$

Temperature in degrees Fahrenheit $\left({ }^{\circ} \mathrm{F}\right)$ may be converted to degrees Celsius $\left({ }^{\circ} \mathrm{C}\right)$ as follows:

$$
{ }^{\circ} \mathrm{C}=\left({ }^{\circ} \mathrm{F}-32\right) / 1.8
$$

Specific conductance is given in microsiemens per centimeter at 25 degrees Celsius $\left(\mu \mathrm{S} / \mathrm{cm}\right.$ at $\left.25^{\circ} \mathrm{C}\right)$.

Concentrations of chemical constituents in water are most often given either in milligrams per liter (mg/L) or micrograms per liter ( $\mu \mathrm{g} / \mathrm{L})$.

One microequivalent per liter ( $\mu \mathrm{eq} / \mathrm{L}$ ) or one milliequivalent per liter (meq/L) is equal to one thousand milligram-equivalents per one thousand milliliters $(\mathrm{meq} / \mathrm{mL})$. Chemical analyses of solutes in a sample are expressed in unit concentrations that are chemically equivalent in terms of atomic or molecular weight and electrical charge.

Water year is the period from 0ctober 1 to September 30 of the following year.

Horizontal coordinate information, where available, is referenced to the North American Datum of 1927 (NAD 27) or North American Datum of 1983 (NAD 83).

Vertical coordinate information, where available, is referenced to the National Geodetic Vertical Datum of 1929 (NGVD 29) or North American Vertical Datum of 1988 (NAVD88). 


\title{
Additional Abbreviations and Acronyms
}

\author{
ABS, Alkylbenzene sulfonate \\ ANC, Acid neutralizing capacity \\ AZ, Arizona \\ AZDEQ, Arizona Department of Environmental Quality \\ BAND, Bandelier National Monument \\ BOR, Bureau of Reclamation \\ $\mathrm{CACH}$, Canyon de Chelly National Monument \\ CDPHE, Colorado Department of Public Health and Environment \\ CHCU, Chaco Culture National Historical Park \\ $\mathrm{CO}$, Colorado \\ DDT, Dichlorodiphenyltrichloroethane \\ DO, Dissolved oxygen \\ GLCA, Glen Canyon National Recreation Area \\ GRCA, Grand Canyon National Park \\ HQCF, High-quality cold-water fishery \\ $\mathrm{I} \& \mathrm{M}$, Inventory and Monitoring \\ LANL, Los Alamos National Laboratory \\ MCL, Maximum contaminant level \\ MEVE, Mesa Verde National Park \\ MPN, Most probable number \\ NAWQ, National Ambient Water Quality \\ NHS, National Historic Site \\ NM, New Mexico \\ NMED, New Mexico Environment Department \\ NMWQCC, New Mexico Water Quality Control Commission \\ NNEPA, Navajo Nation Environmental Protection Agency \\ NP, National Park \\ NPS, National Park Service \\ NRA, National Recreation Area \\ NTU, Nephelometric turbidity units \\ NWIS, National Water Information System \\ PCB, Polychlorinated biphenyls \\ $\mathrm{SC}$, Specific conductance \\ SCPN, Southern Colorado Plateau Network \\ STORET, Storage and Retrieval System \\ SU, Standard units \\ TMDL, Total maximum daily load \\ TRC, Total residual chlorine \\ TVS, Table value standard \\ USCOE, U.S. Army Corps of Engineers \\ USEPA, U.S. Environmental Protection Agency \\ USFS, USDA Forest Service \\ USGS, U.S. Geological Survey \\ UT, Utah \\ UTDWQ, Utah Division of Water Quality \\ VOC, Volatile organic compounds
}





\title{
Review of Available Water-Quality Data for the Southern Colorado Plateau Network and Characterization of Water Quality in Five Selected Park Units in Arizona, Colorado, New Mexico, and Utah, 1925 to 2004
}

\author{
By Juliane B. Brown
}

\begin{abstract}
Historical water-quality data in the National Park Service Southern Colorado Plateau Network have been collected irregularly and with little followup interpretation, restricting the value of the data. To help address these issues, to inform future water-quality monitoring planning efforts, and to address relevant National Park Service Inventory and Monitoring Program objectives, the U.S. Geological Survey, in cooperation with the National Park Service, compiled, reviewed, and summarized available historical water-quality data for 19 park units in the Southern Colorado Plateau Network. The data are described in terms of availability by major water-quality classes, park unit, site type, and selected identified water sources. The report also describes the geology, water resources, water-quality issues, data gaps, and waterquality standard exceedances identified in five of the park units determined to be of high priority. The five park units are Bandelier National Monument in New Mexico, Canyon de Chelly National Monument in Arizona, Chaco Culture National Historical Park in New Mexico, Glen Canyon National Recreation Area in Arizona and Utah, and Mesa Verde National Park in Colorado. Statistical summaries of water-quality characteristics are presented and considerations for future water-quality monitoring are provided for these five park units.
\end{abstract}

\section{Introduction}

Understanding the condition of natural resources is vital to the National Park Service's (NPS) ability to effectively manage park resources. Park management decisions must be integrated with preservation of the national parks for the enjoyment of future generations. Across the Nation, the NPS is facing increasingly challenging issues such as encroaching development; air- and water-quality concerns; recreational effects within and upstream from park units; surrounding land-use activities such as grazing, agriculture, and mining; loss of species diversity and invasion by nonnative species; fire; and extreme weather-related events. To address management concerns, in 1998 the National Parks Omnibus Management Act (P.L. 105-391) created an inventory and monitoring program of park resources to establish baseline information and to provide information on the long-term trends in the condition of National Park System resources. The purpose of this legislation is to "encourage the publication and dissemination of information derived from studies in the NPS" and to "ensure appropriate documentation of resource conditions in the National Park System."

In 1999, the NPS initiated the Inventory and Monitoring (I\&M) Program in response to the 1998 National Parks Omnibus Management Act to establish natural-resource inventory and monitoring as standard practices within the NPS in order to provide a scientific basis for sound park management. To facilitate collaboration, information sharing, and cost sharing for the I\&M Program, park units linked by geography and shared natural-resource characteristics were grouped into 32 monitoring networks. The networks have been working to develop an ecological monitoring strategy involving a series of planning, design, and implementation activities. This strategy is intended to ensure that long-term monitoring efforts will meet key information needs, produce ecologically relevant and scientifically credible data, and make those data available to resource managers. This information includes historical and current monitoring data, available documentation and literature on each park's natural resources, and an understanding of past and present-day resource-management activities. Identifying and monitoring park vital signs (that is, indicators of resource health) is one of the I\&M Program strategies to ensure that all park units with significant natural resources have the information relevant to making effective decisions regarding resource protection and management. "Park vital signs are selected physical, chemical, and biological elements and processes of park ecosystems that represent the overall health or condition of the park" (National Park Service, 2005b, p. 1). Vital signs are intended to characterize and determine trends in the condition of park natural resources in order to assess the effectiveness of restoration and protection activities 
and management approaches and to provide early warning of potential concerns. As part of the I\&M Program, a comprehensive inventory of natural resources is being conducted by each network to identify and prioritize vital signs.

The Southern Colorado Plateau Network (SCPN) is one of 32 monitoring networks being evaluated as part of the I\&M Program. The SCPN is composed of 19 park units in northern Arizona, southwestern Colorado, northwestern New Mexico, and southern Utah. The SCPN staff, park managers and scientists, and collaborating scientists are working together to identify, evaluate, and rank candidate resource "vital signs" through a comprehensive iterative process. Water quality is one of 16 core vital signs identified as integral to the development of a comprehensive ecological monitoring strategy for selected SCPN parks (Thomas and others, 2006). Historical natural-resource monitoring data, including water-quality data, have been sporadically collected and inconsistently managed and commonly have lacked corresponding interpretation, all of which has limited the usefulness of the data. To help address these issues, to inform future water-quality-monitoring planning efforts, and to address selected I\&M Program objectives, the U.S. Geological Survey (USGS), in cooperation with the National Park Service, compiled, reviewed, and summarized available historical water-quality data for the SCPN park units and surrounding areas.

\section{Purpose and Scope}

This report describes the compilation and synthesis of electronically available water-quality data for the 19 SCPN parks. The report describes the SCPN area and provides an overview of data availability for the 19 SCPN park units. Detailed descriptions of historical data and a characterization of water quality are provided for selected surface waters in five high priority SCPN park units. Sediment or fish tissue data are included in this report because they offer insights into water quality for selected waters. These park units are Bandelier National Monument (BAND), Canyon de Chelly National Monument (CACH), Chaco Culture National Historical Park (CHCU), Glen Canyon National Recreation Area (GLCA), and Mesa Verde National Park (MEVE).

\section{Acknowledgments}

The author wishes to express appreciation to employees of the National Park Service, in particular to Stephen Monroe for his assistance and patience with the focus and content of this report. Additionally, the U.S. Geological Survey (USGS), the U.S. Environmental Protection Agency (USEPA), the New Mexico Environment Department (NMED), and the Navajo Nation Environmental Protection Agency (NNEPA) contributed data to the water-quality database compilation effort. The author also expresses gratitude to USGS employees Katie Walton-Day, Doug Druliner, Jean Dupree, David Litke, and Kirby Wynn for their technical or administrative assistance with selected aspects of this project. Finally, the author thanks Stephen Monroe (National Park Service), Margot Truini (USGS Arizona Water Science Center), and M. Alisa Mast (USGS Colorado Water Science Center) for their thorough and helpful technical reviews of this report, and the USGS publications staff for their assistance in preparing this report for publication.

\section{Description of the Southern Colorado Plateau Study Area}

The SCPN is composed of 19 park units: 3 national parks, 13 national monuments, 1 national historic site, 1 national historical park, and 1 national recreation area, located in northern Arizona, southwestern Colorado, northwestern New Mexico, and southern Utah (fig. 1). The parks, which were established for their unique and significant cultural and (or) natural resources, range in size from about 34 acres to greater than 1.2 million acres and total almost 2.9 million acres (table 1). Increased pressures from surrounding land-use activities coupled with substantial increases in the number of recreational visitors present the parks with numerous resourcemanagement challenges.

Most of the 19 SCPN park units are within the southern Colorado Plateau region, except for BAND, Petroglyph National Monument (PETR), and Salinas Pueblo Missions National Monument (SAPU), which are east of the Colorado Plateau in the neighboring physiographic provinces (Southern Rocky Mountains and Basin and Range) in New Mexico. This wide geographic extent results in ecological gradients ranging from lowland, thinly vegetated deserts to transitional woodland mountain zones to subalpine climate and vegetation zones at the highest elevations (Thomas and others, 2006).

Climate in the area can be described as arid to semiarid and is characterized by periods of drought, irregular precipitation, high evapotranspiration rates, high ground-level solar radiation, relatively warm to hot growing seasons, and long winters with sustained periods of freezing temperatures. Generally, precipitation decreases with decreasing elevation and summer precipitation decreases from the southeast part of the Plateau to the northwest (Thomas and others, 2006).

The SCPN is characterized by unpredictable and generally sparse seasonal, annual, and decadal precipitation; relatively high and low seasonal temperature extremes; high evapotranspiration rates; and monsoonal flash-floods (Thomas and others, 2006). This aridity, although interrupted by periods of flooding, results in water being a critical, limiting factor in ecological processes affecting soil moisture, type and distribution of flora and fauna, stream channel geomorphology, and surface conditions throughout the Colorado Plateau area.

Thomas and others (2004) provide a detailed overview of the Colorado Plateau landforms and geology. The Colorado Plateau is formed by undeformed, slanted, multilayered blocks of sedimentary rock that range from Precambrian to Tertiary 


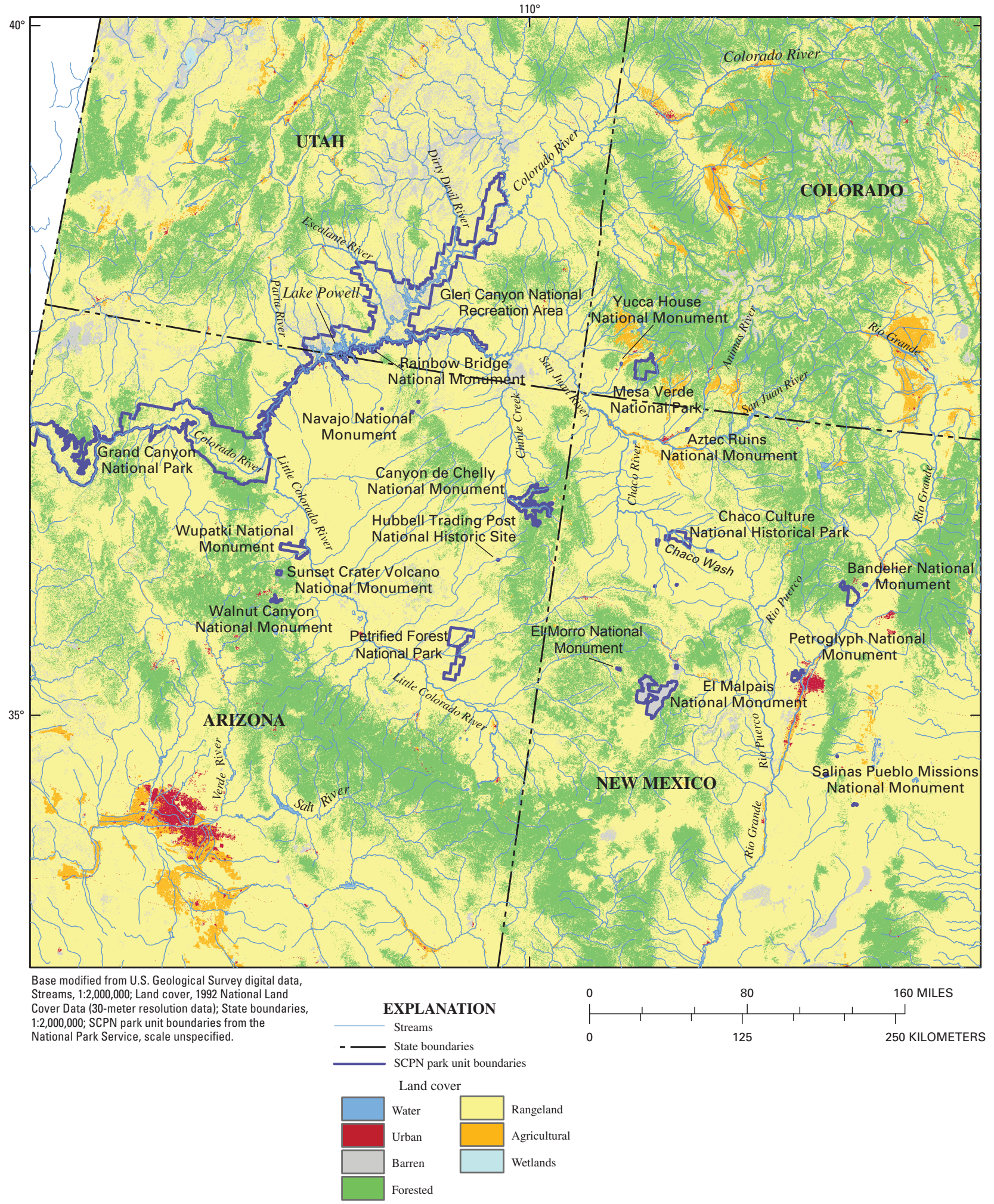

Figure 1. Southern Colorado Plateau Network (SCPN) showing park boundaries, land cover, and principal surface-water bodies. 
Table 1. National Park Service units in the Southern Colorado Plateau Network, including acreage, State, and visitation statistics.

[AZ, Arizona; CO, Colorado; NM, New Mexico; UT, Utah; --, no data available; park units detailed in this report shown in bold]

\begin{tabular}{|c|c|c|c|c|c|}
\hline $\begin{array}{l}\text { SCPN } \\
\text { park }\end{array}$ & $\begin{array}{c}\text { Park } \\
\text { abbreviation }\end{array}$ & State & Acres $^{1}$ & $\begin{array}{c}\text { Number of } \\
\text { recreational } \\
\text { visitors in } 2005^{2}\end{array}$ & $\begin{array}{l}\text { Percent change in number } \\
\text { of visitors from first } \\
\text { recorded year to } 2005 \\
\text { (Number of visitors in } \\
\text { first year, first year) }\end{array}$ \\
\hline Aztec Ruins National Monument & AZRU & NM & 257 & 44,050 & $607(6,234,1923)$ \\
\hline Bandelier National Monument & BAND & NM & 32,831 & 250,161 & $5,908(4,164,1932)$ \\
\hline $\begin{array}{l}\text { Canyon de Chelly National } \\
\text { Monument }\end{array}$ & $\mathrm{CACH}$ & $\mathrm{AZ}$ & 83,840 & 830,253 & $196,177(423,1931)$ \\
\hline $\begin{array}{l}\text { Chaco Culture National } \\
\text { Historical Park }\end{array}$ & $\mathrm{CHCU}$ & $\mathrm{NM}$ & 32,840 & 45,539 & $2,177(2,000,1925)$ \\
\hline El Malpais National Monument & ELMA & $\mathrm{NM}$ & 109,612 & 116,194 & $393(23,546,1988)$ \\
\hline El Morro National Monument & ELMO & $\mathrm{NM}$ & 1,040 & 51,825 & $2,491(2,000,1920)$ \\
\hline $\begin{array}{l}\text { Glen Canyon National } \\
\text { Recreation Area }\end{array}$ & GLCA & AZ/UT & $1,239,764$ & $1,908,726$ & $872(196,400,1964)$ \\
\hline Grand Canyon National Park & GRCA & $\mathrm{AZ}$ & $1,180,863$ & $4,401,522$ & $11,561(37,745,1919)$ \\
\hline $\begin{array}{l}\text { Hubbell Trading Post } \\
\text { National Historic Site }\end{array}$ & HUTR & $\mathrm{AZ}$ & 160 & 95,676 & $91(50,200,1968)$ \\
\hline Mesa Verde National Park & MEVE & $\mathrm{CO}$ & 51,891 & 498,333 & $622,816(80,1908)$ \\
\hline Navajo National Monument & NAVA & $\mathrm{AZ}$ & 360 & 54,688 & $85,350(64,1920)$ \\
\hline Petrified Forest National Park & PEFO & $\mathrm{AZ}$ & 109,002 & 598,378 & $19,846(3,000,1919)$ \\
\hline $\begin{array}{l}\text { Petroglyph National } \\
\text { Monument }\end{array}$ & PETR & NM & 2,929 & 102,623 & $51(68,065,1992)$ \\
\hline Rainbow Bridge National Monument & RABR & UT & 160 & 81,206 & $57,087(142,1923)$ \\
\hline $\begin{array}{l}\text { Salinas Pueblo Missions } \\
\text { National Monument }\end{array}$ & SAPU & $\mathrm{NM}$ & 985 & 34,810 & $3,381(1,000,1925)$ \\
\hline $\begin{array}{l}\text { Sunset Crater Volcano } \\
\text { National Monument }\end{array}$ & SUCR & $\mathrm{AZ}$ & 3,040 & 229,913 & $9,097(2,500,1934)$ \\
\hline Walnut Canyon National Monument & WACA & $\mathrm{AZ}$ & 3,289 & 128,275 & $1,183(10,000,1934)$ \\
\hline Wupatki National Monument & WUPA & $\mathrm{AZ}$ & 35,422 & 219,480 & $43,796(500,1925)$ \\
\hline Yucca House National Monument & YUHO & $\mathrm{CO}$ & 34 & -- & -- \\
\hline
\end{tabular}

${ }^{1}$ From National Park Service, Land Resources Division, 2006.

${ }^{2}$ From National Park Service, Public Use Statistics Office (2006) for recreation visitors only. 
in age. The youngest (Tertiary) rocks are found in the northern and eastern boundary, where the Rocky Mountains adjoin the Colorado Plateau, and the oldest (Precambrian) rocks are found along the southern and western boundary, where the Plateau adjoins the Basin and Range Province. Bare rock covers extensive areas of the Colorado Plateau's surface. Common structural features across the Plateau include basins, monoclines (the most common structural feature), fault blocks, salt structures, igneous domal uplifts, and upwarps.

Within the Colorado Plateau, the largest and most extensive water resource is the Colorado River, which flows through Grand Canyon National Park (GRCA) and Glen Canyon National Recreation Area (GLCA). Lake Powell in GLCA is the largest surface-water body on the plateau (fig. 1). Major tributaries that drain from the east to the Colorado River from areas surrounding and including most of the SCPN park units include the Little Colorado and San Juan Rivers. On the far eastern side of the SCPN, the areas of four park units-BAND, El Malpais National Monument (ELMA), PETR, and SAPU_-drain into the Rio Grande Basin. Rivers bound four park units in the network, including Aztec Ruins National Monument (AZRU; Animas River), BAND (Rio Grande), MEVE (Mancos River), and Wupatki National Monument (WUPA; Little Colorado River). Parks supporting small perennial drainages include BAND (Capulin Creek, Rito de los Frijoles, and Alamo Creek), CACH (Tsaile Creek, Wheatfields Creek, Coyote Wash, and Black Rock Canyon), Navajo National Monument (NAVA; Keet Seel Canyon), and SAPU (Cañon Espinoso and Cañon Sapato). Numerous perennial tributaries to the Colorado River flow through GLCA and GRCA as well. Parks with significant intermittent or ephemeral drainages are CHCU (Chaco Wash), Hubbell Trading Post National Historic Site (HUTR; Pueblo Colorado Wash), and Petrified Forest (PEFO; Little Colorado River). Wildlife and vegetation at El Morro National Monument (ELMO) are sustained by tinajas (that is, natural ephemeral water holes usually found in rock hollows or unconsolidated material and periodically filled by rain or snow), potholes (that is, small depressional wetlands), and small pools. ELMO, Sunset Crater National Monument (SUCR), and PETR are dry most of the time. A vast network of perennial, intermittent and ephemeral springs, pools, washes, and streams sustain the larger water bodies and their associated riparian corridor; these areas collectively support the diverse flora and fauna throughout the region. The intermittent and ephemeral features typically flow during spring runoff or following rainfall. Unique and significant water-dependent features such as hanging gardens and cottonwood stands are supported by springs. Many of these water bodies, including many of the intermittent and ephemeral washes and arroyos, have been altered to enhance streambank stability, channel flow, water storage, and stormflow drainage (Thomas and others, 2006).

Ground water is a critical resource in this region and provides the source water for springs that, in turn, provide critical support for flora and fauna, contribute to stream baseflow (for perennial waters), and provide water supplies for multiple park units. Three principal aquifers, the Coconino (C aquifer), Redwall-Muav, and Navajo (N aquifer), are particularly important to several SCPN parks. The C aquifer, which is an extensive, regional aquifer underlying more than $27,000 \mathrm{mi}^{2}$ of the Little Colorado River Basin (and parts of the Salt and Verde River Basins) in north-central Arizona and which is principally contained in the water-bearing Coconino Sandstone rock unit, provides the water supplies to HUTR, PETR, SUCR, Walnut Canyon National Monument (WACA), and WUPA (Thomas and others, 2006; Hart and others, 2002). The Redwall-Muav aquifer, which underlies the $\mathrm{C}$ aquifer, is the principal watersupply source to GRCA (Bills and others, 2007). The N aquifer is the main water source in the Black Mesa area in the Navajo and Hopi Indian Reservations in northeastern Arizona and provides the water supply for NAVA (Thomas and others, 2006; Eychaner, 1983).

\section{Compilation of Data}

The NPS Southern Colorado Plateau Network and the USGS cooperated in acquisition, organization, management, and synthesis of available water-quality data associated with the waters of the SCPN parks as part of the I\&M Program activities. Electronically available water-quality data were retrieved (as recently collected as January 2004) for sampling sites located within, adjacent to, and upstream from the 19 park areas. A relational water-quality $\mathrm{Microsoft}^{\odot}$ Access database houses the compiled historical water-quality data (on file at National Park Service office, Southern Colorado Plateau I\&M Network, Northern Arizona University, Flagstaff, Arizona).

The sources of data compiled for the SCPN water-quality database include Federal (USGS, USEPA, NPS, U.S. Department of Agriculture Forest Service [USFS], Bureau of Reclamation [BOR], U.S. Army Corps of Engineers [USCOE]), State (Colorado Department of Public Health and Environment [CDPHE], Utah Division of Water Quality [UTDWQ], Arizona Department of Environmental Quality [ADEQ], and NMED), Tribal agencies (NNEPA), and volunteer monitoring organizations (Colorado Division of Wildlife Colorado River Watch). The data consist of water-quality and water-quantity information for streams, springs, lakes (including ponds, lakes, and reservoirs), diversions and outfalls, and ground water. Most of the data were obtained in electronic format from the USEPA Modernized Storage and Retrieval System (Modern STORET) and Legacy Data Center (Legacy STORET) databases (http://www.epa.gov/storet/dbtop.html, last accessed April 13, 2007) and the USGS National Water Information System (NWIS) database (http://nwis.waterdata.usgs.gov/usa/ nwis/rt, last accessed April 13, 2007).

Within the boundaries of the 19 park areas, water-quality data were retrieved for 602 sites: 160 streams or rivers, 160 springs, 207 ponds, lakes or reservoirs, 70 water wells, 3 outfalls, and 2 diversions. Where available, additional data 
were retrieved for sites adjacent to and upstream from the park boundaries. Approximately 2,306 different field properties or constituents were included in the retrieval. The period of record, data collected, and sampling agencies varied among water-quality sites, and many sites had data for only one or a few samples. Sampling methodology, analytical methods, and quality assurance were not available for much of the historical data, which limited data comparability and interpretation.

Several important water-quality datasets were not included in the data compilation effort due to the scope of the project. These datasets include the GRCA and GLCA data collected as part of the Grand Canyon Monitoring and Research Center that are not included in STORET or NWIS, and data collected by the Los Alamos National Laboratory in and near BAND. Data-collection activities, subsequent to the SCPN data compilation efforts, including Level 1 Water-Quality Inventory sampling in 13 SCPN parks in 2005 and 2006 (Macy and Monroe, 2006), also were not incorporated into the database or this report. Historical water-quality data available for individual parks are documented in the Baseline Water Quality Data Inventory and Analysis ("Horizon") Reports (http://wwwl.nature.nps.gov/water/horizon.cfm, last accessed April 9, 2007). However, due to differences in the approach and timing of the SCPN data compilation effort, datasets associated with Horizon reports were not used as source data for the SCPN database.

\section{Analysis of Data}

To more directly address water-quality vital sign monitoring planning goals of the SCPN, substantially fewer sites and field properties or constituents are evaluated for and presented in this report; data from wells, diversions, canals, and most lakes or reservoirs were not analyzed for this report. Evaluation of data availability (that is, identification of data-rich compared to data-poor areas for each park) was conducted prior to data analysis. The field properties analyzed for this report are acid neutralizing capacity, dissolved oxygen, $\mathrm{pH}$, specific conductance, turbidity, and water temperature. Constituent classes analyzed include major ions, nutrients, trace elements, and bacteriological data. Selected additional constituent classes (for example, pesticides) are mentioned where relevant to a particular park's available water-quality data. Streamflow data are summarized, where available.

Data analysis consisted of evaluating a subset of the compiled water-quality data, checked against additional data-quality criteria, with a focus on data from sites located within park boundaries for water bodies of interest identified by SCPN personnel as high priority. Data analysis included the nondetect (that is, unquantified) data. Prior to analysis, unquantified data were reassigned to a numeric censoring level based on information available from each analysis of sample for a given constituent. The values (hereinafter referred to as "censoring levels") used to recensor these nondetect data were based on one of several descriptors historically used to explain unquantified data, including analytical detection limits, long-term method detection limits, lower quantification limits, practical quantitation limits, or minimum, interim, or laboratory reporting levels. Data analysis methods included computation of summary statistics and comparison of data to State water-quality standards and (or) selected Federal water-quality criteria. Additional analyses included the use of trilinear (Piper) diagrams to characterize the chemical composition of selected water bodies and comparison of relative concentrations of selected constituents between sampling sites. Water-quality data are strongly site-dependent, and results are assessed within this context, especially when a water body is characterized on the basis of a small number of sampling points. Of the more than 180,000 traceelement results in the compiled SCPN water-quality dataset, representing 40 trace elements, many had too few samples to support statistical analyses when constituent descriptors, including sample fraction (for example, filtered or unfiltered) and speciation (for example, iron III, chromium VI) and geographic factors, including site type, park association, and water body, were considered.

A basic data-quality assessment check of results in the SCPN database was performed to identify potential outliers and unreasonable results. This assessment considered the typical range of values used by the USEPA since 1983 to assess data in Legacy STORET (National Park Service, 1997). The USGS NWIS Water-Quality User Manual also was consulted for evaluating properties and constituents that can be recensored (that is, assigned the value of "less than the censoring level") if the stored value is zero, and for properties and constituents that allow negative values (U.S. Geological Survey, 2006). Errantly zero or negative results were identified and recensored or quarantined (that is, removed from the database and excluded from subsequent analysis), as appropriate. Obviously errant data were quarantined from the database (for example, $\mathrm{pH}=-12$ ).

An additional data-quality check included comparison of "total" (unfiltered) and "dissolved" (filtered) concentrations of selected constituents in water samples collected from spring and stream sites within park boundaries as well as from major or important water bodies in and near park units. Constituents evaluated for quality-control checks of total and dissolved concentrations include selected major ions (calcium, magnesium, sodium, and sulfate), nutrients (nitrate and phosphorus), and trace elements (aluminum, cadmium, copper, selenium, and zinc). Values affected by censoring and results where one or both values in a pair were zero were excluded. Generally, few of the potential results were paired, which limited the usefulness of this analysis as an approach to quality check the overall dataset.

Major-ion balance was computed for each sample with adequate data to check the accuracy of major constituent analyses. Ion balance (IB) is a charge balance of cations (C), including calcium, magnesium, potassium, and sodium, and anions (A), including bicarbonate or carbonate, chloride, 
fluoride, nitrates [nitrate and nitrite], and sulfate in a water sample. The ion balance, in milliequivalents per liter $(\mathrm{meq} / \mathrm{L})$, is calculated by using the following equation: IB $=100 \times(\Sigma \mathrm{C}-\Sigma \mathrm{A}) /(\Sigma \mathrm{C}+\Sigma \mathrm{A})$. Samples with major-ion imbalances exceeding 15 percent were excluded from the analyses (Katherine Walton-Day, U.S. Geological Survey, oral commun., 2006). Historical data collected before March 1983 did not include adequate information to calculate a charge balance on samples.

A water-quality value identified as suspect by any quality-assurance measure was considered individually and collectively (relative to other samples collected from or near the site), taking into consideration the sampling season, site location, and available historical data. Results were flagged in the database if they exceeded one or more of these criteria. Overall, the data available for these evaluations were few. Only a few hundred paired or grouped values were available for comparison, but thousands of data results were available for one or more constituents with unpaired or nongrouped values. Few of the water bodies of interest summarized for this report were identified as having poor data quality; many of them, however, lacked sufficient data to be evaluated. Generally, the results of the data-quality checks indicate acceptable quality with few exceptions.

\section{Computation of Descriptive Statistical Measures}

The minimum, median, and maximum values were identified or computed for the selected evaluated waters in BAND, $\mathrm{CACH}, \mathrm{CHCU}, \mathrm{GLCA}$, and MEVE parks. All median values were computed using S-Plus 6.1 for Windows Professional Edition $^{\odot}$ (Insightful Corporation, 2007).

For censored data, medians were computed using a logprobability regression method, which is considered a robust technique even if the data are not log-normally distributed (Helsel and Cohn, 1988). This method does not compute a value when the percentage of censored values exceeds 95 percent, or if there are fewer than three uncensored values, or if all of the uncensored values are equal. Constituents that were measured below the censoring level for all samples were not included in the descriptive statistical summaries.

\section{Comparison to State Water-Quality Standards}

For the purpose of identifying the levels (measurements, concentrations, or values) of potential or actual water-quality field properties or constituents of concern to individual parks and the SCPN network, results of analyses of samples collected since 1987 (recent data) were compared to State standards or Federal criteria. A summary of selected aquaticlife numeric water-quality standards for Arizona, Colorado, New Mexico, and Utah is provided in table 2.

In most cases, chronic aquatic-life and (or) primaryor secondary-recreation standards were used to evaluate water-quality data collected in evaluated waters due to the importance of ecological integrity and recreation to the NPS. Occasionally, domestic water-supply, drinking-water, or livestock watering standards were used for comparing water quality of springs or other water-quality data to State standards when no aquatic-life or recreation standards applied. Exceedances in this report are defined as reported values greater than the established water-quality standard, which may not conform directly to State-specific approaches for evaluating water bodies for standards exceedances. Where insightful, exceedances for data collected prior to 1988 are identified within the text to indicate historical exceedance patterns, but these data are not included in the exceedance information on the summary tables.

Numeric standards for trace elements vary by State, and selected trace-element criteria - table value standards (TVS) are computed based on the hardness of the water at a given site (table 2). Not all trace elements are regulated. Where no applicable State standards have been established, select Federal criteria were used for comparison purposes to identify field properties and constituents of potential ecological concern. These criteria include the USEPA National Recommended Nutrient Criteria for Ecoregions II and III for total nitrogen and total phosphorus (U.S. Environmental Protection Agency, 2002), and the National Ambient Water Quality criteria (NAWQ) or secondary chronic (Tier II) values for selected unregulated trace elements (Suter and Tsao, 1996). The concentrations of the selected unregulated trace elements are compared to the NAWQ criteria or the Tier II values as two toxicological benchmarks useful for screening constituents for possible aquatic-ecological effects. In this report, comparisons to the chronic NAWQ criteria were completed for all detected trace elements without applicable State chronic aquatic-life numeric standards or TVS. If State and NAWQ criteria were not available for a trace element, the chronic Tier II value was evaluated relative to reported values.

\section{Overview of Water Quality and Southern Colorado Plateau Network Park Units}

\section{Available Water-Quality Data for Parks}

Water-quality data available for SCPN parks varies by park, site type (for example, stream, spring, or lake), field properties measured, analyses of constituents, frequency of collection, and period of record. Out of the 19 SCPN park units, historical water-quality data were collected in 13 parks at one or more stream sites; in 11 parks at one or more springs; at 14 parks with one or more ground-water sites; and at 7 parks with one or more lake, reservoir, pond, or pool sites (table 3). Park units were classified as "data rich" or "data 
Table 2. Selected aquatic-life stream-segment numeric water-quality standards for selected field properties and constituents for Southern Colorado Plateau parks.

[AM 1/3, not to exceed arithmetic mean once in 3 years; dav, day-average; fil, filtered; H, naturally high; Inst, instantaneous; L, naturally low; lk, lake; N, nitrogen; NTU, nephelometric turbidity units; sp, spawning; st, stream; Temp, temperature; tr, total (unfiltered) recoverable; TVS, table value standard; --, no applicable standard; $24 \mathrm{GMM}$, geometric mean maximum 24 hours apart; $\mu \mathrm{S} / \mathrm{cm}$, microsiemens per centimeter]

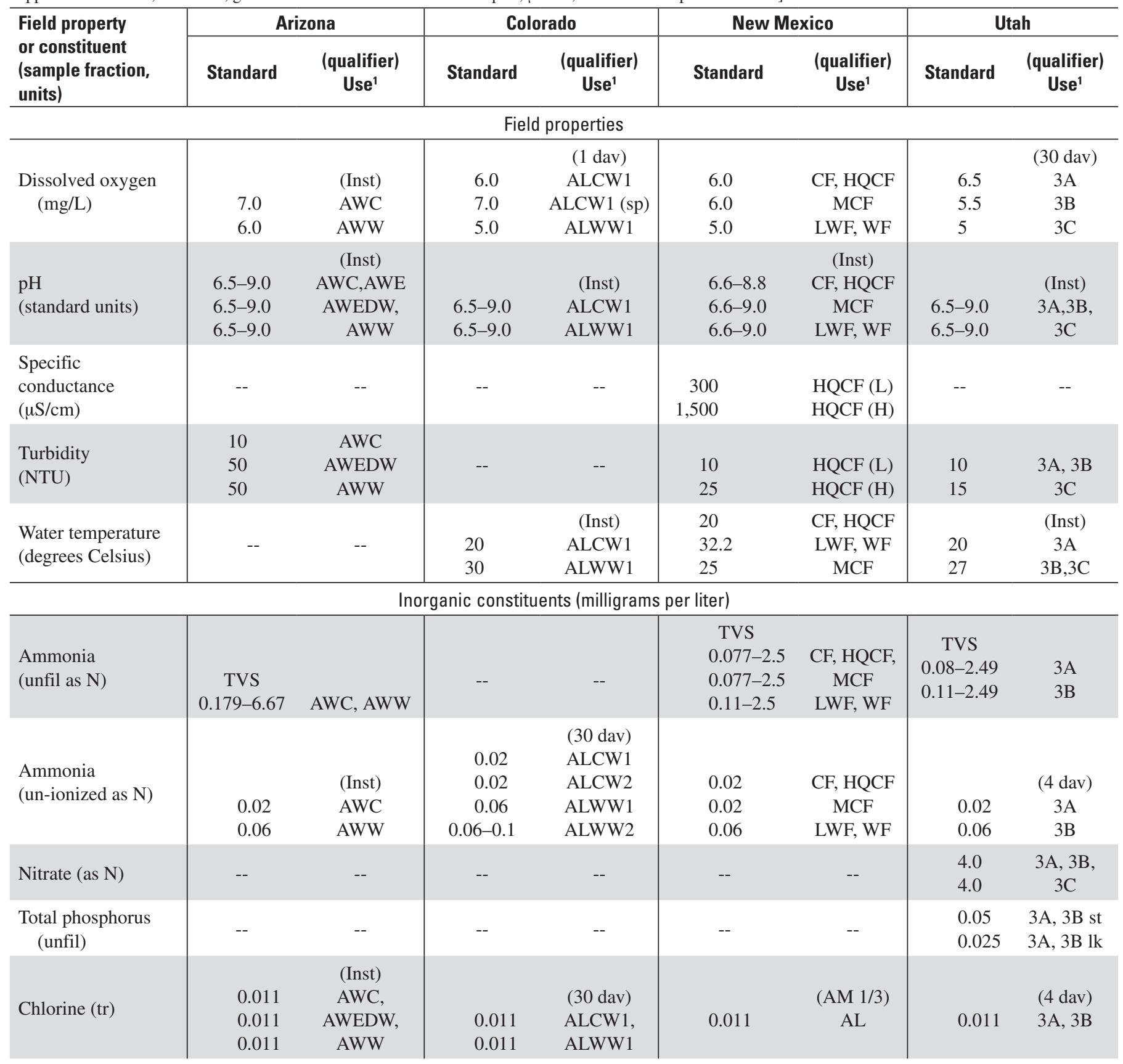


Table 2. Selected aquatic-life stream-segment numeric water-quality standards for selected field properties and constituents for Southern Colorado Plateau parks.-Continued

[AM 1/3, not to exceed arithmetic mean once in 3 years; dav, day-average; fil, filtered; H, naturally high; Inst, instantaneous; L, naturally low; lk, lake; N, nitrogen; NTU, nephelometric turbidity units; sp, spawning; st, stream; Temp, temperature; tr, total (unfiltered) recoverable; TVS, table value standard; --, no applicable standard; 24 GMM, geometric mean maximum 24 hours apart; $\mu \mathrm{S} / \mathrm{cm}$, microsiemens per centimeter]

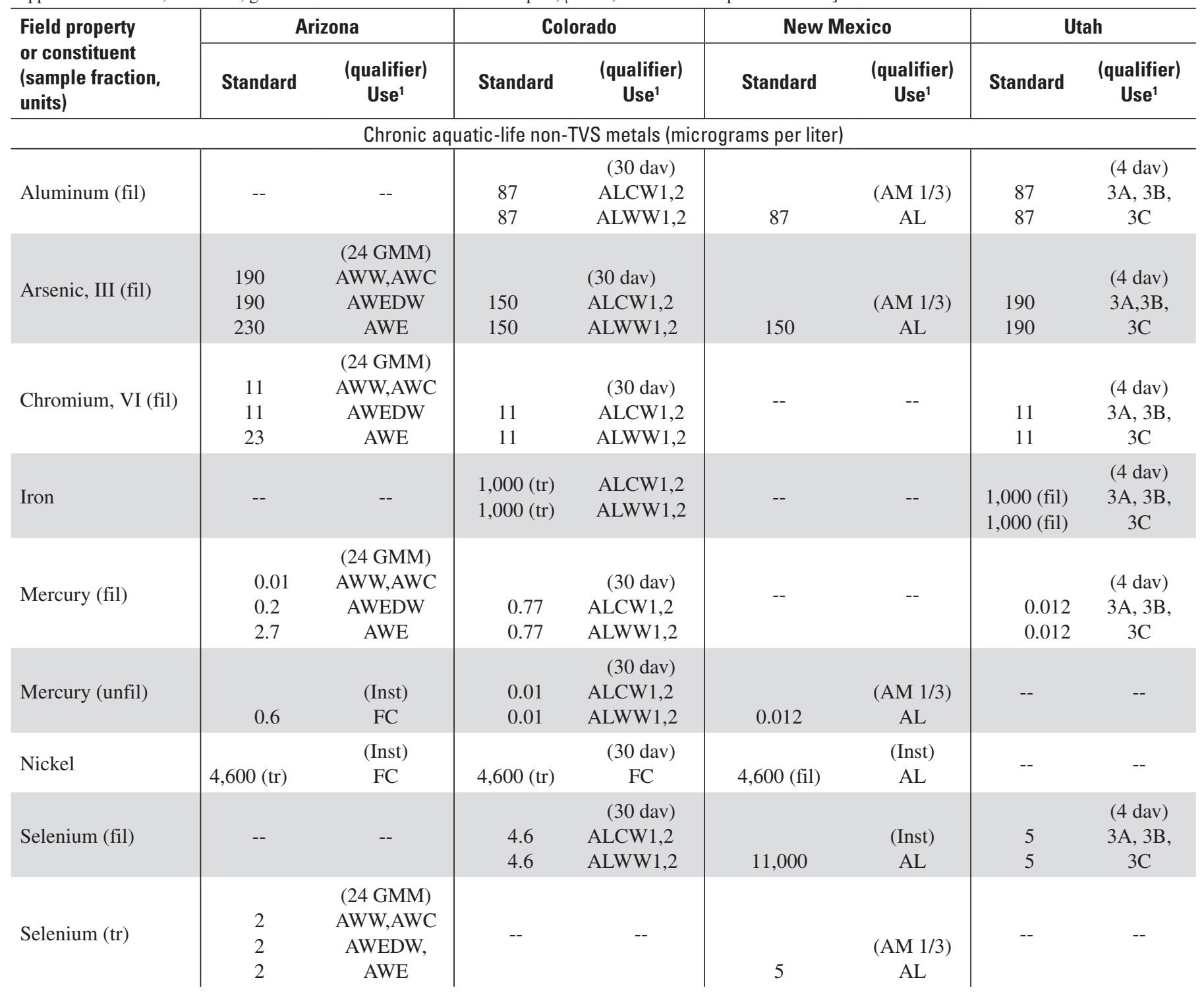


Table 2. Selected aquatic-life stream-segment numeric water-quality standards for selected field properties and constituents for Southern Colorado Plateau parks.-Continued

[AM 1/3, not to exceed arithmetic mean once in 3 years; dav, day-average; fil, filtered; H, naturally high; Inst, instantaneous; L, naturally low; lk, lake; N, nitrogen; NTU, nephelometric turbidity units; sp, spawning; st, stream; Temp, temperature; tr, total (unfiltered) recoverable; TVS, table value standard; --, no applicable standard; $24 \mathrm{GMM}$, geometric mean maximum 24 hours apart; $\mu \mathrm{S} / \mathrm{cm}$, microsiemens per centimeter]

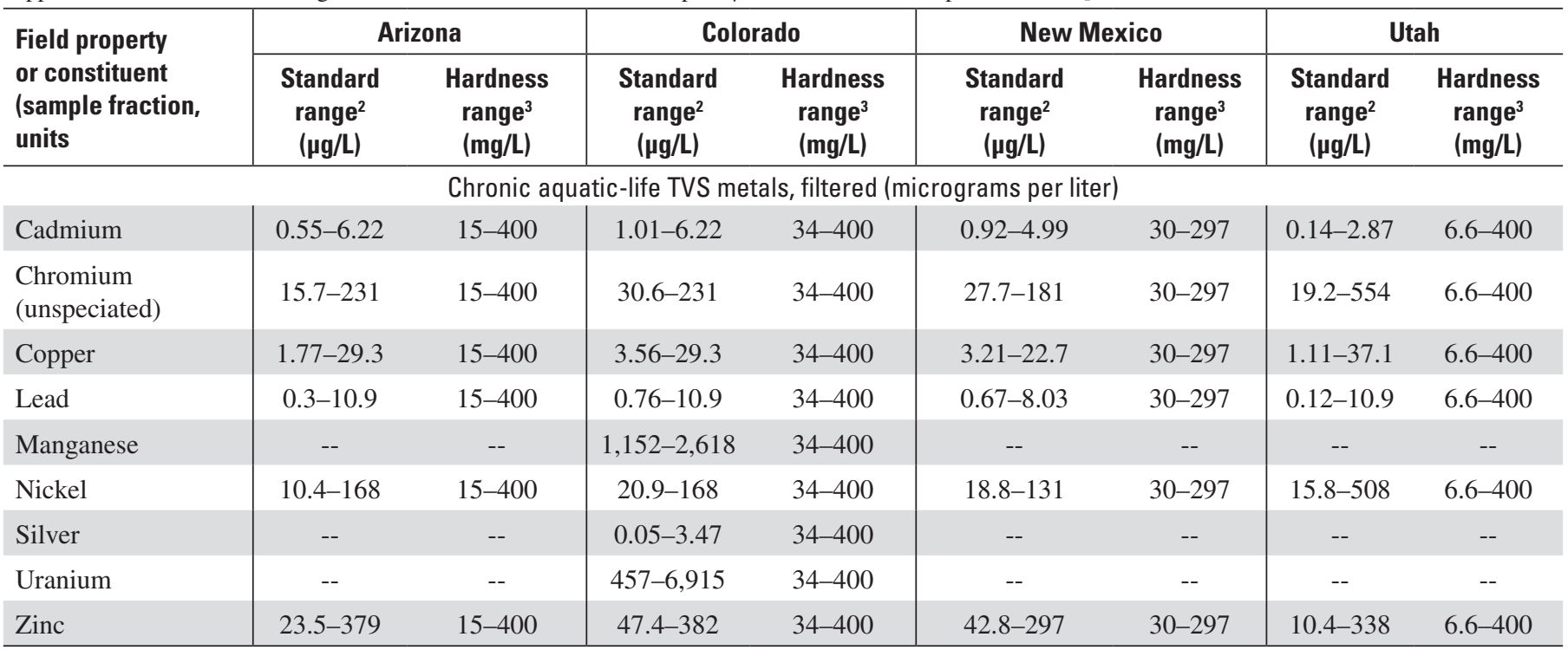

${ }^{1}$ Designated beneficial use codes for aquatic life used in the table are defined, by State, as follows:

Arizona - FC, fish consumption; AWW, aquatic and wildlife warm water; AWEDW, aquatic and wildlife effluent-dependent water; AWE, aquatic and wildlife ephemeral; AWC, aquatic and wildlife cold water (State of Arizona, 2002). Colorado - ALCW1,2, aquatic-life cold-water classes 1 and 2; ALWW1,2, aquatic-life warm-water classes 1 and 2; FC, fish consumption (Colorado Department of Public Health and Environment, 2005). New Mexico - MCF, marginal cold-water fishery; LWF, limited warm-water fishery; HQCF, high-quality cold-water fishery; AL - aquatic life; WF - warm-water fishery; CF - coldwater fishery (State of New Mexico, 2002). Utah - 3A, aquatic-life cold; 3B, aquatic-life warm; 3C, aquatic-life support (Utah Department of Environmental Quality, 2005).

${ }^{2}$ Ranges provided are for all aquatic-life uses combined for each State.

${ }^{3}$ Hardness values used to compute site-specific table value standards. Hardness values were capped at $400 \mathrm{mg} / \mathrm{L}$ based on State regulations; therefore, where 15 -year mean hardness is computed to be higher than $400 \mathrm{mg} / \mathrm{L}$, the hardness value was set to $400 \mathrm{mg} / \mathrm{L}$. All other hardness values are based on 15 -year arithmetic mean of available data for a given site. TVS only computed for sites with actual hardness data available for consideration.

poor" based on the number and type of samples and the period of record. This type of classification provides a general categorization of available water-quality data for individual parks. Data-poor parks are those with fewer than 10 samples for any given site type (table 3). Data-rich parks included parks with greater than 100 water-quality samples for any given site type (table 3). The earliest and latest sampling date should not be construed to suggest that there are monitoring data available during the entire period between these dates; however, it does provide an idea of how long the park unit has been conducting water-quality monitoring as part of its resource-management activities.

A summary of available water-quality data is presented by site type and constituent class in table 4 . This summary shows that most of the data collected falls within four analytical classes: field properties, major ions, nutrients, and trace elements. It also is evident that most data are for stream and spring sites. The exception is GLCA, which has a large amount of lake data. By this approach, only four parks have a data-rich history (that is, greater than 100 samples for a given constituent or field property and site type) for one or more site types and one or more constituent classes; these parks are BAND, CHCU, GLCA, and GRCA (fig. 1).

\section{Water-Quality Issues Identified by Parks}

As part of the Phase I and II activities of the NPS I\&M Program, park personnel identified water-quality resource concerns in and surrounding each park unit. These concerns are summarized in table 5 and are based on information contained in the Phase I and II SCPN reports (Thomas and others, 2003; Thomas and others, 2004). Water-quality stressors identified most frequently include erosion, extreme weather events, water withdrawals, trespass grazing, urban development, and invasive exotics. 
Table 3. Numbers of streams, springs, lakes (includes reservoirs, ponds, or pools), and ground-water sites and water samples collected within Southern Colorado Plateau Network park boundaries, and period of record, 1925 to 2003.

[No., number; -, no sites or samples; nonbold text indicates data-poor parks for site types with fewer than 10 samples; bold text indicates datarich parks for site types with 100 or more samples]

\begin{tabular}{|c|c|c|c|c|c|c|c|c|c|}
\hline \multirow{2}{*}{$\begin{array}{l}\text { Park } \\
\text { (table 1) }\end{array}$} & \multicolumn{2}{|c|}{ Streams } & \multicolumn{2}{|c|}{ Springs } & \multicolumn{2}{|c|}{$\begin{array}{l}\text { Lakes, reservoirs, } \\
\text { ponds, or pools }\end{array}$} & \multicolumn{2}{|c|}{$\begin{array}{l}\text { Ground } \\
\text { water }\end{array}$} & \multirow{2}{*}{$\begin{array}{l}\text { Period of } \\
\text { record }\end{array}$} \\
\hline & $\begin{array}{l}\text { No. of } \\
\text { sites }\end{array}$ & $\begin{array}{c}\text { No. of } \\
\text { samples }\end{array}$ & $\begin{array}{l}\text { No. of } \\
\text { sites }\end{array}$ & $\begin{array}{c}\text { No. of } \\
\text { samples }\end{array}$ & $\begin{array}{l}\text { No. of } \\
\text { sites }\end{array}$ & $\begin{array}{c}\text { No. of } \\
\text { samples }\end{array}$ & $\begin{array}{l}\text { No. of } \\
\text { sites }\end{array}$ & $\begin{array}{c}\text { No. of } \\
\text { samples }\end{array}$ & \\
\hline AZRU & - & - & - & - & - & - & 1 & 1 & 1990 \\
\hline BAND & 28 & 1,116 & 6 & 154 & 1 & 9 & - & - & 1951-2001 \\
\hline $\mathrm{CACH}$ & 4 & 13 & - & - & 3 & 19 & 2 & 3 & 1949-2003 \\
\hline $\mathrm{CHCU}$ & 8 & 748 & - & - & - & - & 14 & 26 & 1956-1987 \\
\hline ELMA & 3 & 3 & 10 & 16 & 1 & 1 & 6 & 6 & 1978-1995 \\
\hline ELMO & 2 & 2 & - & - & 10 & 29 & 2 & 2 & 1962-1996 \\
\hline GLCA & 59 & 4,685 & 43 & 73 & 178 & 3,330 & 22 & 72 & 1926-2003 \\
\hline GRCA & 49 & 4,009 & 54 & 129 & - & - & 1 & 1 & 1925-2003 \\
\hline HUTR & 3 & 18 & 1 & 5 & - & - & 1 & 1 & 1949-2003 \\
\hline $\mathrm{MEVE}^{1}$ & 2 & 2 & 37 & 103 & 17 & 28 & - & - & 1975-1998 \\
\hline NAVA & - & - & 4 & 10 & - & - & 2 & 4 & 1962-2002 \\
\hline PEFO & 1 & 3 & - & - & - & - & 5 & 17 & 1969-2000 \\
\hline PETR & 2 & 6 & - & - & - & - & 2 & 3 & 1957-1993 \\
\hline RABR & - & - & - & - & - & - & - & - & - \\
\hline SAPU & 4 & 6 & 5 & 14 & 1 & 1 & 4 & 4 & 1950-2001 \\
\hline SUCR & - & - & - & - & - & - & - & - & - \\
\hline WACA & - & - & 1 & 2 & - & - & 3 & 9 & 1970-2002 \\
\hline WUPA & 1 & 1 & 3 & 6 & - & - & 4 & 14 & 1954-2002 \\
\hline YUHO & - & - & 1 & 4 & - & - & - & - & 2002-2003 \\
\hline
\end{tabular}

${ }^{1}$ MEVE is only park with samples from diversions (two sites; four samples) and outfalls (three sites, seven samples) located inside the park boundary. 
Table 4. Number of water samples by site type and constituent class for sites within Southern Colorado Park Network park boundaries, 1925 to 2003.

[GW, ground water; LK, lake, reservoir, pond or pool; SP, springs and seeps; ST, stream; VOCs, volatile organic compounds; WWCs, wastewater compounds; sample counts for park sites with greater than 100 samples in a given class shown in bold; sample counts for park sites with fewer than 10 samples in a given class shown in grey text; RABR and SUCR had zero samples for all site types and constituent classes]

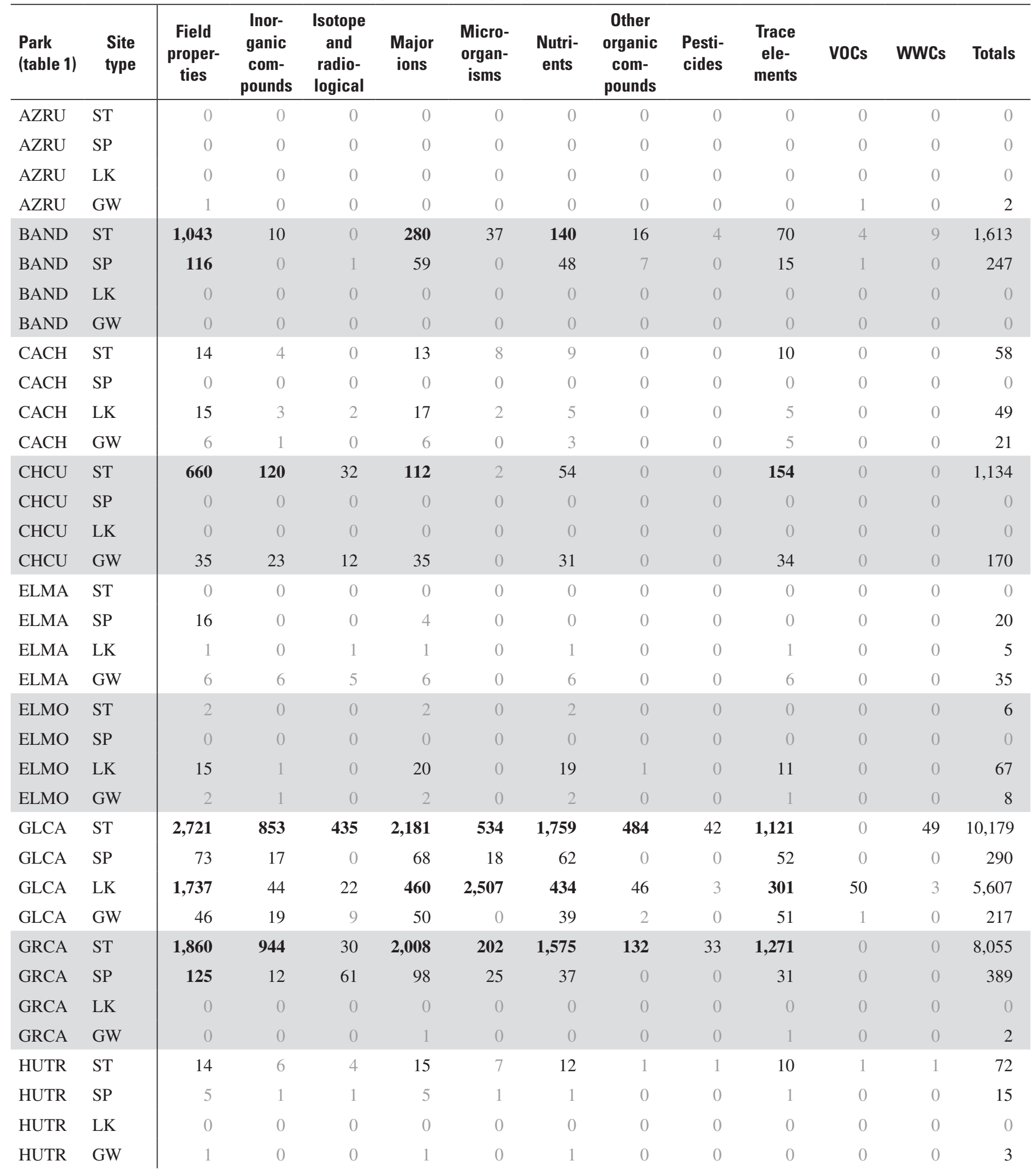


Table 4. Number of water samples by site type and constituent class for sites within Southern Colorado Park Network park boundaries, 1925 to 2003. - Continued

[GW, ground water; LK, lake, reservoir, pond or pool; SP, springs and seeps; ST, stream; VOCs, volatile organic compounds; WWCs, wastewater compounds; sample counts for park sites with greater than 100 samples in a given class shown in bold; sample counts for park sites with fewer than 10 samples in a given class shown in grey text; RABR and SUCR had zero samples for all site types and constituent classes]

\begin{tabular}{|c|c|c|c|c|c|c|c|c|c|c|c|c|c|}
\hline $\begin{array}{l}\text { Park } \\
\text { (table 1) }\end{array}$ & $\begin{array}{l}\text { Site } \\
\text { type }\end{array}$ & $\begin{array}{c}\text { Field } \\
\text { proper- } \\
\text { ties }\end{array}$ & $\begin{array}{c}\text { Inor- } \\
\text { ganic } \\
\text { com- } \\
\text { pounds }\end{array}$ & $\begin{array}{l}\text { Isotope } \\
\text { and } \\
\text { radio- } \\
\text { logical }\end{array}$ & $\begin{array}{c}\text { Major } \\
\text { ions }\end{array}$ & $\begin{array}{c}\text { Micro- } \\
\text { organ- } \\
\text { isms }\end{array}$ & $\begin{array}{l}\text { Nutri- } \\
\text { ents }\end{array}$ & $\begin{array}{c}\text { Other } \\
\text { organic } \\
\text { com- } \\
\text { pounds }\end{array}$ & $\begin{array}{l}\text { Pesti- } \\
\text { cides }\end{array}$ & $\begin{array}{l}\text { Trace } \\
\text { ele- } \\
\text { ments }\end{array}$ & VOCs & WWCs & Totals \\
\hline MEVE & ST & 1 & 0 & 0 & 1 & 0 & 1 & 0 & 0 & 1 & 0 & 0 & 4 \\
\hline MEVE & SP & 71 & 67 & 1 & 71 & 31 & 67 & 0 & 0 & 71 & 0 & 0 & 379 \\
\hline MEVE & LK & 18 & 18 & 0 & 18 & 15 & 18 & 0 & 0 & 18 & 0 & 0 & 105 \\
\hline NAVA & ST & 0 & 0 & 0 & 0 & 0 & 0 & 0 & 0 & 0 & 0 & 0 & 0 \\
\hline NAVA & SP & 9 & 5 & 0 & 9 & 9 & 9 & 0 & 0 & 9 & 0 & 0 & 50 \\
\hline NAVA & LK & 0 & 0 & 0 & 0 & 0 & 0 & 0 & 0 & 0 & 0 & 0 & 0 \\
\hline NAVA & GW & 4 & 2 & 0 & 4 & 3 & 4 & 0 & 0 & 3 & 0 & 0 & 20 \\
\hline PEFO & GW & 16 & 14 & 5 & 18 & 0 & 13 & 0 & 0 & 17 & 0 & 0 & 83 \\
\hline PETR & $\mathrm{ST}$ & 6 & 5 & 0 & 2 & 3 & 2 & 2 & 2 & 2 & 2 & 2 & 28 \\
\hline PETR & SP & 0 & 0 & 0 & 0 & 0 & 0 & 0 & 0 & 0 & 0 & 0 & 0 \\
\hline PETR & LK & 0 & 0 & 0 & 0 & 0 & 0 & 0 & 0 & 0 & 0 & 0 & 0 \\
\hline PETR & GW & 3 & 2 & 0 & 3 & 0 & 3 & 0 & 0 & 2 & 0 & 0 & 13 \\
\hline SAPU & ST & 3 & 0 & 0 & 3 & 0 & 3 & 0 & 0 & 0 & 0 & 0 & 9 \\
\hline SAPU & SP & 12 & 0 & 0 & 12 & 0 & 12 & 0 & 0 & 0 & 0 & 0 & 36 \\
\hline SAPU & LK & 1 & 0 & 0 & 1 & 0 & 1 & 0 & 0 & 1 & 0 & 0 & 4 \\
\hline WUPA & SP & 6 & 3 & 0 & 5 & 2 & 4 & 0 & 0 & 3 & 0 & 0 & 23 \\
\hline WUPA & LK & 0 & 0 & 0 & 0 & 0 & 0 & 0 & 0 & 0 & 0 & 0 & 0 \\
\hline WUPA & GW & 10 & 4 & 2 & 14 & 0 & 11 & 2 & 0 & 8 & 2 & 0 & 53 \\
\hline YUHO & ST & 2 & 1 & 0 & 2 & 0 & 2 & 0 & 0 & 1 & 0 & 0 & 8 \\
\hline YUHO & SP & 4 & 4 & 0 & 4 & 0 & 2 & 0 & 0 & 4 & 0 & 0 & 18 \\
\hline YUHO & LK & 1 & 1 & 0 & 1 & 0 & 1 & 0 & 0 & 1 & 0 & 0 & 5 \\
\hline YUHO & $\mathrm{GW}$ & 0 & 0 & 0 & 0 & 0 & 0 & 0 & 0 & 0 & 0 & 0 & 0 \\
\hline \multicolumn{2}{|c|}{ TOTAL } & 8,692 & 2,195 & 626 & 5,627 & 3,409 & 4,403 & 696 & 85 & 3,305 & 65 & 64 & \\
\hline
\end{tabular}


Table 5. Summary of water-quality stressors by park identified by Southern Colorado Plateau Network park personnel during Phase I and Phase II of the Inventory and Monitoring Program activities.

[N, not identified as a stressor; Y, yes, identified as a stressor; parks detailed in this report shown in bold]

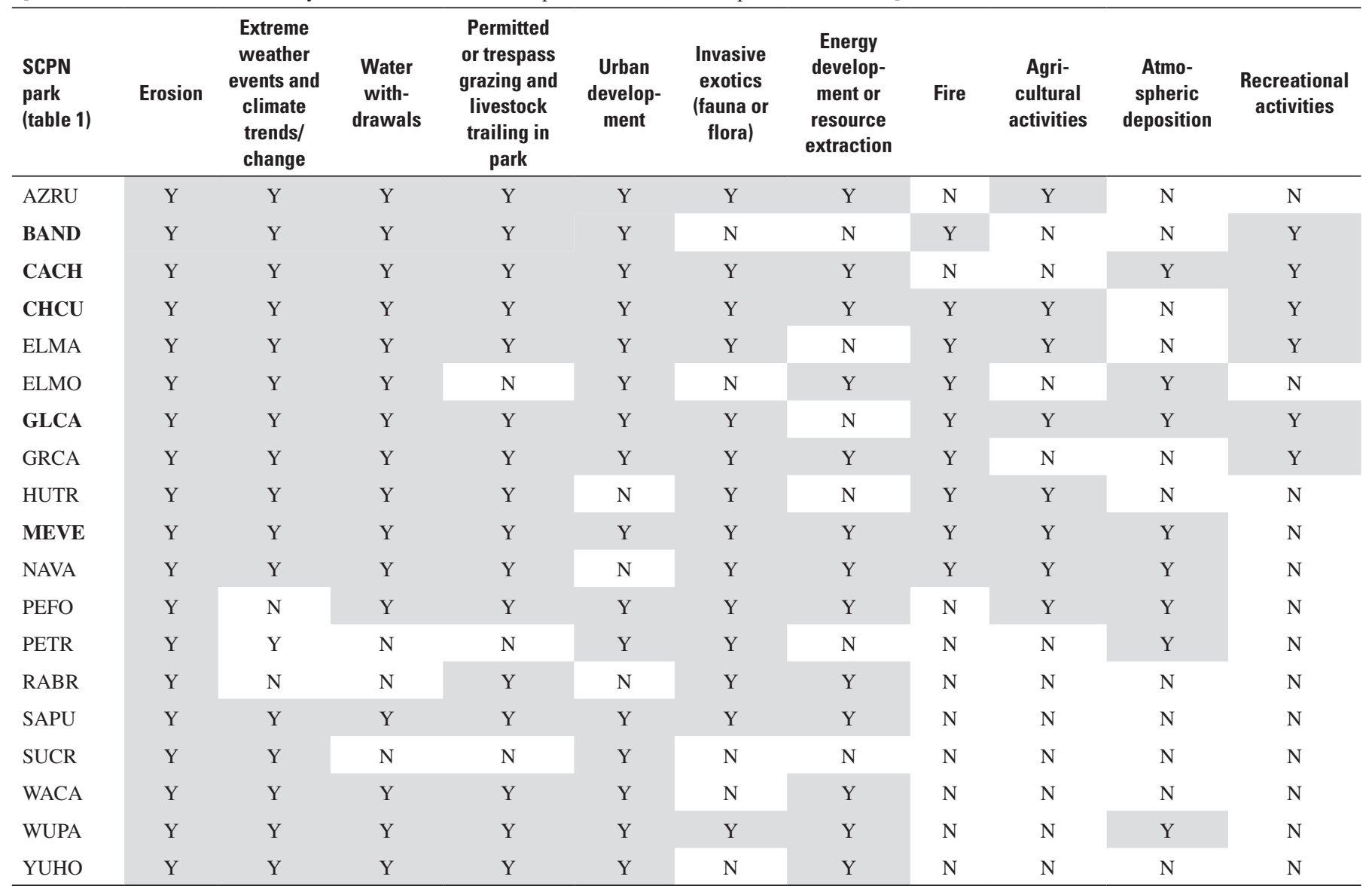




\section{Impaired Waters}

Section 303(d) of the 1972 Clean Water Act requires States, territories, and authorized tribes to develop and prioritize a list of impaired waters that do not currently meet water-quality standards. For listed waters, a TMDL (total maximum daily load) must be developed specifying the maximum loading of a contaminant a waterbody can receive to meet water-quality standards. TMDLs also allocate loads among point- and nonpoint-pollutant sources and background conditions (U.S. Environmental Protection Agency, 2006a).
Chelly National Monument (CACH), Chaco Culture National Historical Park (CHCU), Glen Canyon National Recreation Area (GLCA), and Mesa Verde National Park (MEVE). Values for selected field properties and concentrations of major ions, nutrients, other constituents (bacteria, organic compounds, suspended solids, and suspended sediment), trace elements, and radionuclides were used to characterize water quality for selected sites of interest in each park.

The field properties evaluated in this report are acid neutralizing capacity (ANC), dissolved oxygen (DO), hardness, $\mathrm{pH}$, specific conductance (SC), streamflow, turbidity, and

\section{SCPN park unit and water body}

Reason for 303(d) listing

\begin{tabular}{|c|c|}
\hline Animas River & Sedimentation \\
\hline \multicolumn{2}{|c|}{ Bandelier National Monument } \\
\hline Rito de los Frijoles & $\begin{array}{l}\text { Elevated dichlorodiphenyltrichloroethane (DDT) concentrations, fecal } \\
\text { coliform counts, water temperature, and turbidity levels }\end{array}$ \\
\hline Capulin Creek & Sedimentation, diminished integrity of benthic macroinvertebrates \\
\hline Sandia Canyon & $\begin{array}{l}\text { Presence of polychlorinated biphenols (PCBs), nonsupport of wildlife } \\
\text { habitat }\end{array}$ \\
\hline Los Alamos Canyon & $\begin{array}{l}\text { Elevated selenium concentrations and gross alpha counts, nonsupport } \\
\text { of livestock watering, and wildlife habitat }\end{array}$ \\
\hline Pueblo Canyon & $\begin{array}{l}\text { Elevated concentrations of selenium and mercury, elevated gross } \\
\text { alpha counts, nonsupport of livestock watering, and wildlife habitat }\end{array}$ \\
\hline
\end{tabular}

Glen Canyon National Recreation Area

Paria River (from Utah border to confluence with Colorado River)

Elevated concentrations of suspended sediment

Grand Canyon National Park

Colorado River (from Parashant Canyon to Diamond Creek)

Elevated concentrations of suspended sediment and selenium

Several water bodies in four SCPN park units are considered impaired for one or more causes and currently (2007) are included on the 303(d) list, on the basis of assessments made in 2004. The listed water bodies include:

The development of TMDLs for Capulin Creek and the Rito de los Frijoles was begun in 2005, but the process has not been completed.

\section{Characterization of Water Quality for Five Southern Colorado Plateau Network Park Units}

Water-quality conditions and data availability were evaluated for five SCPN park units in which water quality was identified as a high-priority vital sign. The units evaluated for this report are Bandelier National Monument (BAND), Canyon de water temperature. Of these, $\mathrm{DO}, \mathrm{pH}, \mathrm{SC}$, and water temperature were commonly measured at most sites and were typically collected more frequently and for longer periods of record than any other water-quality property.

The major ions evaluated in this report are bicarbonate, calcium, chloride, fluoride, magnesium, potassium, silica, sodium, and sulfate; ion concentrations are filtered unless specifically stated otherwise. Where adequate data were available, water types are described for selected sites. Major ion data are not included in the summary tables as no water-quality criteria are associated with these constituents.

The nutrients evaluated in this report are ammonia (total and un-ionized), nitrate, nitrate plus nitrite, nitrite, nitrogen (total), orthophosphorus, and total phosphorus. Of these, nitrate and total phosphorus were typically the most frequently sampled constituents. Sample fraction is specified for individual nutrients summarized in this report and can vary by constituent, site, and (or) park unit. Selected nutrients 
(unfiltered and filtered nitrate, nitrite, and orthophosphorus) were aggregated to facilitate analysis following the methodology in Mueller and others (1995).

Data for other constituents, including bacteriological (that is, Escherichia coli, fecal coliform, and total coliform), chlorine, dissolved solids, organic compounds, suspended solids, and suspended sediment are summarized, when available, though samples for these constituents were typically infrequently and irregularly analyzed. Geometric means are reported for bacteriological data. In terms of the SCPN park waters, there were very few analyses of synthetic organic compounds in samples (primarily selected pesticides) collected in or near park areas; therefore, these data are mentioned only within applicable park-specific sections. Additionally, while dissolved and total organic carbon and related data such as chemical and biological oxygen demand were compiled in the SCPN water-quality database, they are not evaluated within this report.

Many trace elements, including aluminum, arsenic, barium, beryllium, cadmium, chromium, copper, iron, lead, manganese, mercury, molybdenum, nickel, selenium, silver, strontium, uranium, and zinc were summarized in this report. For this report, trace elements were selected for analysis based on available data, relative importance of the constituent from a regulatory or aquatic toxicological perspective, and relative importance of the trace element to understanding water-quality conditions at a park or water-source level. When analyzing historical unfiltered trace-element data collected by the USGS (or agencies using the same or similar methods) it is important to consider that sample-collection techniques, including method and equipment, changed in the early 1990s to address contamination concerns following evaluation by the USGS Office of Water Quality (U.S. Geological Survey, 1991). Of particular concern from this evaluation were dissolved (filtered) trace-element concentrations of arsenic, boron, beryllium, cadmium, chromium, copper, lead, mercury, and zinc and possibly aluminum, iron and manganese, which may well be a result of filtration artifacts rather than contamination. Sample fraction is specified for individual trace elements summarized in this report and can vary by constituent, site, and (or) park unit.

Radiological constituents summarized herein include alpha and beta radioactivity, gross alpha and beta radioactivity, plutonium-238, radium-226, radium-226 plus radium-228, strontium-90, tritium, uranium-234, uranium-235, and uranium-238. Radionuclide data were generally collected infrequently.

Data are summarized for selected sites and parks based on availability of water-quality data collected within the last 60 years (1947 to 2004), though the same field properties and constituents were not always measured or analyzed in samples from all sites in or among park units. An overview of the various water-quality field properties and constituents evaluated for this report is provided in the Appendix to provide a background for interpreting the park-specific analyses.

\section{Bandelier National Monument, New Mexico}

Bandelier National Monument (BAND) is in northcentral New Mexico on the eastern slopes of the Sierra de los Valles and Pajarito Plateau (fig. 2). BAND was established in 1916 to recognize an array of archeological, historical, and natural features (Rothman, 1988). The 32,831-acre monument is composed of two areas: the main section is south and southwest of Los Alamos National Laboratory (LANL), and the smaller 800-acre Tsankawi section is southeast of LANL. BAND comprises six canyons, which dissect the Pajarito Plateau in a northwest to southeast direction. The northwestern part of BAND is in the Sierra de los Valles of the Jemez Mountains, the remains of a large volcano known as the Valles Caldera (Wing, 1957; Christensen, 1980). South of the Jemez Mountains lie the San Miguel Mountains, which border the west side of the main monument. The Rio Grande forms the southeastern boundary of the monument and captures all of the drainage from the canyons.

Overall, BAND has a semiarid, temperate, continental mountain climate (Mott, 1999). Climate station 290743 is in BAND at an elevation of 6,060 ft northwest of the visitors' center (fig. 2). The mean annual precipitation is about 15 inches (1941-76) with August typically recorded as the wettest month (2.9 inches) and November the driest (0.65 inch) (Western Regional Climate Center, 2006). Average monthly air temperatures ranged from $28.6^{\circ} \mathrm{F}$ in January to $71.7^{\circ} \mathrm{F}$ in July, with an average annual temperature of $50.2^{\circ} \mathrm{F}$, and with daily extremes ranging from $-32^{\circ} \mathrm{F}$ on January 7,1971 , to $106^{\circ} \mathrm{F}$ on July 8, 1951 (Western Regional Climate Center, 2006).

\section{Geology}

A few principal geological features influence water quality in BAND. The upper surface of the Pajarito Plateau, known locally as the "Bandelier Tuff," was formed from eruption of the Valles Caldera (Purtymun and Adams, 1980). The Bandelier Tuff, up to $200 \mathrm{ft}$ thick, forms the Pajarito Plateau and the monument's cliff-forming units. The Puye Formation, a large alluvial fan complex, underlies most of this unit, and Cerros del Rio basalt underlies the Bandelier Tuff in the eastern part of the Pajarito Plateau near the Rio Grande's White Rock Canyon. The Pajarito Fault, which separates the Jemez Mountains on the west from the Pajarito Plateau on the east and generally trends along the western border of LANL, is a major structural feature in the park that plays a critical role in ground-water movement and is a source of spring discharges in the perennial drainages (Mott, 1999; McCalpin, 2005). Generally geologic sections in BAND show a base layer of lava or basalt overlain by ash-derived Bandelier Tuff, capped by another layer of lava that forms the rimrock of the mesa. In some locations this pattern is repeated several times (that is, lava or basalt is overlain by tuff capped by more lava) and is further complicated by faulting and interim periods of erosion (Wing, 1957). 


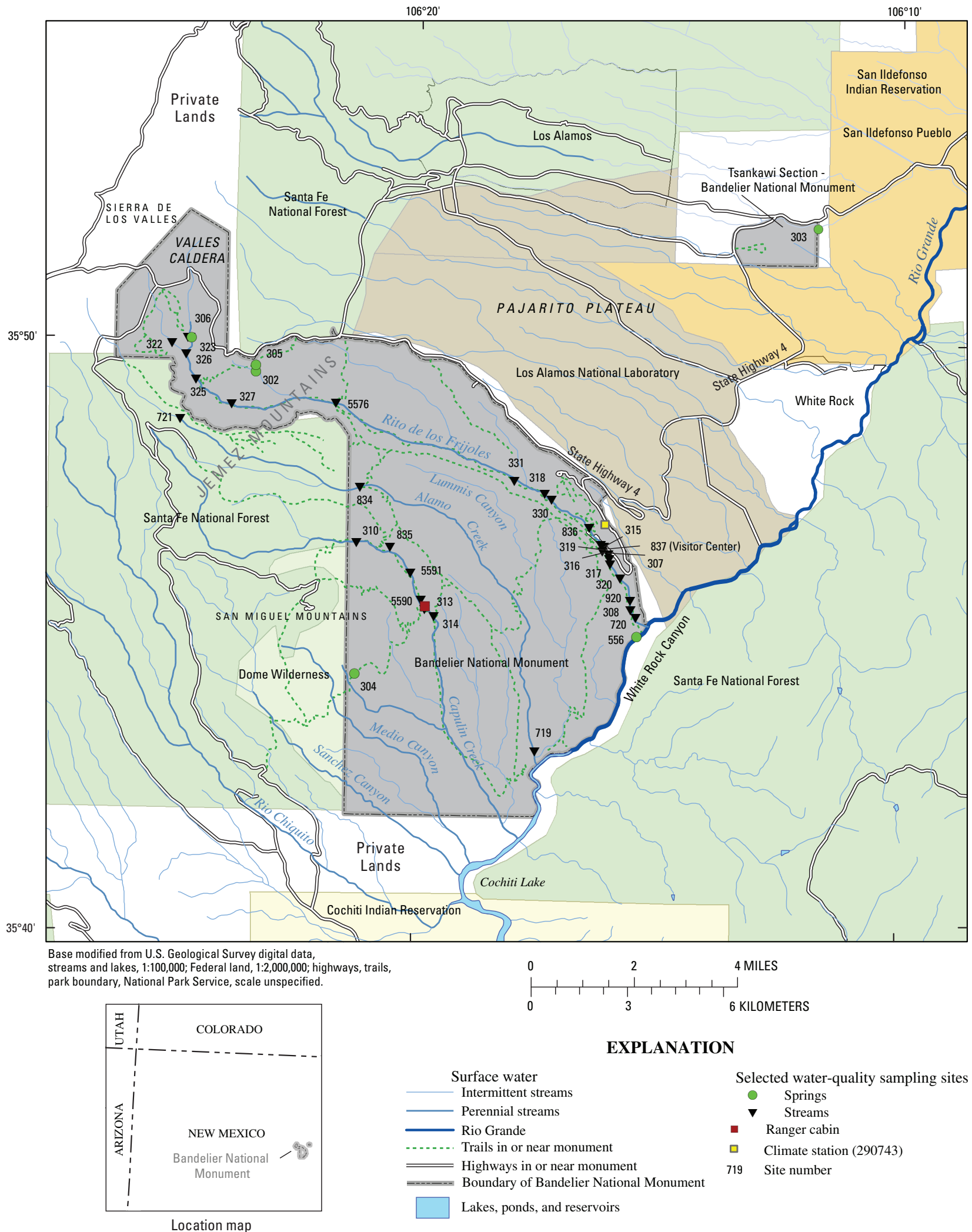

Figure 2. Bandelier National Monument, New Mexico, and locations of water-quality sampling sites. 


\section{Water Resources}

Bandelier National Monument includes the perennial Rito de los Frijoles (Upper and Lower Frijoles Creek) and five other major north-northwest- to south-southeast-draining canyons, including the Lummis, Alamo, Capulin, Medio, and Sanchez Canyons (fig. 2). These canyons receive base flow from springs that discharge along the mountain and plateau interface and drain to the Rio Grande and Cochiti Lake. A 5.5-mi reach of the Rio Grande flows along the southwestern border of the monument; however, only the west bank and associated riparian area are within Bandelier's boundaries.

From March 1983 to September 1996, a streamflowgaging station, USGS station 08313350 , was operated on the Rito de los Frijoles in the monument; the station has since been taken over by LANL (site 307 in fig. 2; table 6). Peakflow data were collected intermittently from this same station, starting in June 1965 and continuing through May 2003. Streamflow at this station generally was highest during April and May (5.80 cubic feet per second, $\mathrm{ft}^{3} / \mathrm{s}$ ) and lowest in July $\left(1.22 \mathrm{ft}^{3} / \mathrm{s}\right)$. The highest annual streamflow was recorded in water year $1987\left(4.49 \mathrm{ft}^{3} / \mathrm{s}\right)$ and the lowest in water year 1996 $\left(0.78 \mathrm{ft}^{3} / \mathrm{s}\right)$. The highest peak flow was recorded on July 21 , 1978 , at $3,030 \mathrm{ft}^{3} / \mathrm{s}$. Average annual runoff, based on 14 years of record, was 1.63 inches from the 17.5-square-mile drainage basin (U.S. Geological Survey, 2001). Typical annual hydrographs for Pajarito Plateau canyons show flashy responses to summer monsoons and snowmelt-driven peaks in mid-spring (Mott, 1999). There are a number of other streamflow-gaging stations operated on the Rito de los Frijoles and Capulin Creek, which are summarized by Mott (1999) and Purtymun and Adams (1980). Evapotranspiration, which is the major water-loss route from the Pajarito Plateau, combined with alluvial sediment storage and downward migration to deeper water-bearing zones limit the amount of streamflow leaving the area's canyons (Mott, 1999). Mott provides an updated discussion of the complex ground-water flow paths in and near the monument and suggests potential flow paths for LANL contaminants that could be affecting the Rito de los Frijoles or possibly Alamo Creek.

Discharge from springs support base flow in the canyons. Four named springs within the park: Basalt (site 303), Turkey (site 304), Apache (site 305), and Frijoles (site 556) Springs, were further analyzed in this report (fig. 2; table 6). Turkey Spring (site 304) discharges from volcanic rocks associated with the Valles Caldera and provides perennial flow of a tributary canyon to Capulin Creek. Discharge from these springs ranges from less than 0.95 gallon per minute (gpm) at Apache Spring to approximately $22.2 \mathrm{gpm}$ at Turkey Spring (Purtymun and Adams, 1980). Two additional springs, Sawyer Spring (site 302), which is very near Apache Spring, and Upper Frijoles East Fork Spring (site 306), which is in the headwaters of the Rito de los Frijoles, were identified during the historical data compilation; however, no information is available on these sites from the park or in the literature. There was only one sample collected in 1961 from site 302 and two samples collected in 1977 and 1978 from site 306 (fig. 2; table 6). The Upper Frijoles East Fork Spring (also called the North Fork Spring of Frijoles Canyon) discharges from a perched aquifer from fractured volcanic rocks associated with the Valles Caldera and contributes to the base flow in the Rito de los Frijoles (Purtymun and Adams, 1980).

Wildfires in 1977 (La Mesa Fire) and 1996 (Dome Fire) each burned more than 15,000 acres in the adjacent Santa Fe National Forest, the Rito de los Frijoles and Capulin Creek drainages, and the surrounding Dome Wilderness area (fig. 2). These fires resulted in flow-regime changes with increased number, magnitude, and frequency of peak flows in the Capulin Creek and Rito de los Frijoles drainages (Veenhuis, 2002). In 2000, the Cerro Grande Fire burned more than 100,000 acres of Santa Fe National Forest, the LANL, and the monument. Aquatic biota shifts to disturbance-tolerant invertebrates and reduced taxa density were documented as a result of the postfire flash flooding associated with these largescale wildfires, and postfire floods in the monument revealed elevated concentrations of selected cations, nutrients (nitrogen and phosphorus), and sediment (Vieira and others, 2004).

Purtymun and Adams (1980) reported elevated concentrations of major constituents (bicarbonate and calcium), trace elements (barium, iron, lead, manganese, and zinc), and phenols in storm runoff in the Rito de los Frijoles drainage following the 1977 wildfire.

Cochiti Lake, at the southeast boundary of the monument on the Rio Grande, is one of the 10 largest earthfill dams in the United States built between 1965 and 1975 for flood and sediment control on the Rio Grande (Public Law 86-645; U.S. Congress, 1960). Cochiti Lake, which is principally within the boundaries of the Pueblo de Cochiti Reservation, also now serves as a perennial source of water for fish, wildlife, and recreation (U.S. Congress, 1964). The flood easement held for the dam by the USCOE allows as many as 361 acres of the monument to be inundated; flooding has occurred in the canyons in BAND several times, including 1979 and 1985. These floods destroyed hiking trails, eroded the shoreline, deposited drift litter (including [human] garbage), threatened and damaged archeological ruins, damaged boundary and drift fences (leading to additional trespass grazing by feral cattle), and damaged riparian vegetation, including the extirpation of six plant species from the park that had been present at Frijoles Spring (Rothman, 1988; Allen and others, 1993). The recreational mandate for the reservoir requires 1,200 acres of open water to be maintained, and the pool levels must be continually readjusted upward because of the expanding sediment delta. This process results in regular flooding and changing ecological characteristics of the reservoir's backwater areas in the monument (Mott, 1999).

According to the State of New Mexico 2004-2006 Integrated Clean Water Act $\S 303(d) / \S 305($ b) report, several streams in the Upper Rio Grande Basin flowing through the monument are listed as impaired on the 303(d) list for one or more water-quality constituents (State of New Mexico, 2004). Capulin Creek is impaired for high-quality cold-water fishery 
Table 6. Stream and spring sites with water-quality data in or upstream from Bandelier National Monument, New Mexico, 1951 to 2001.

[abv, above; blw, below; DD, decimal degrees; E., east; mi, mile; no., number; USFS, USDA Forest Service; USGS, U.S. Geological Survey; W., west; Site no. shown in figure $2 ; *$, site 721 located outside monument boundary; site names retained from original source database]

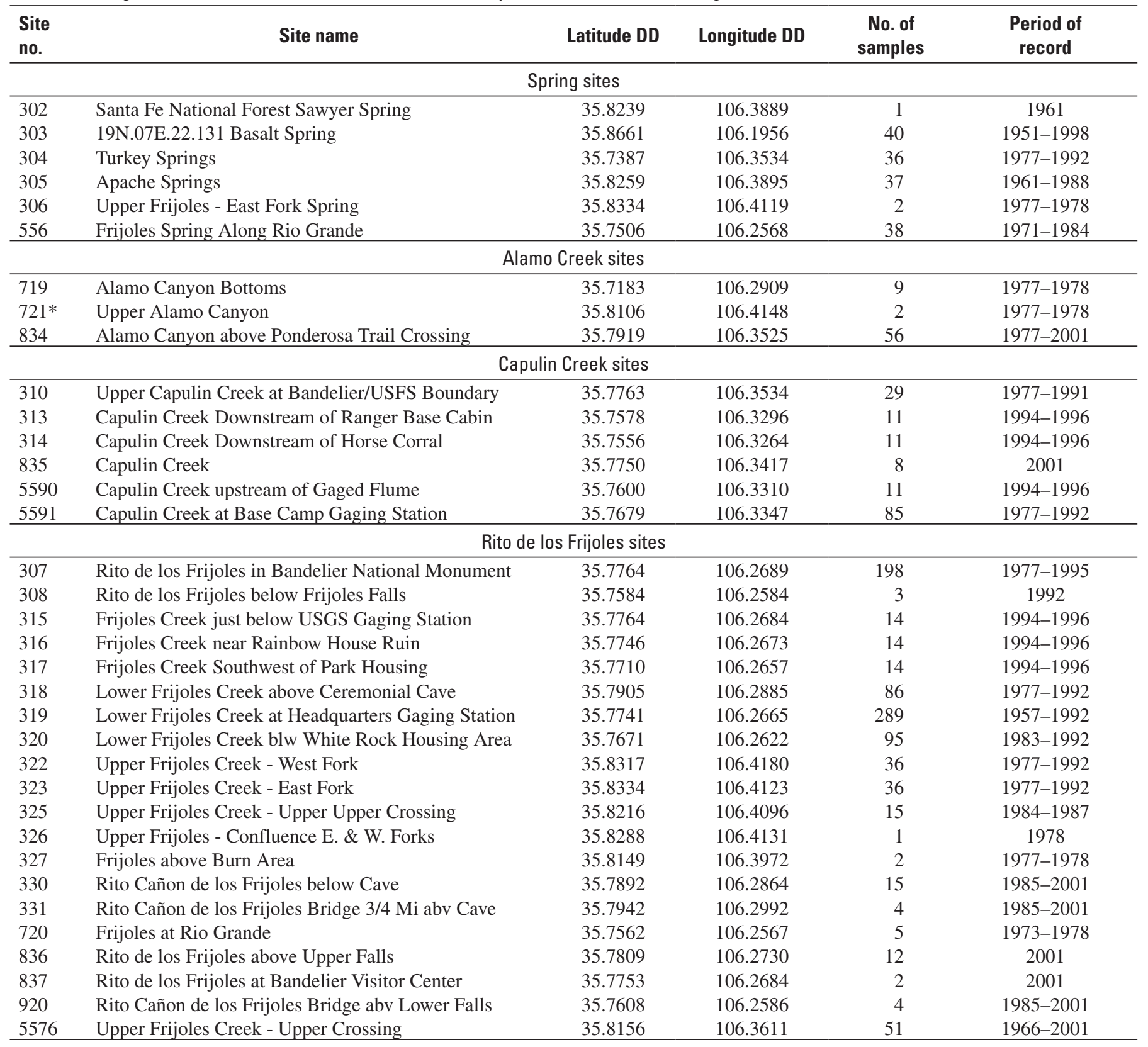


(HQCF) based on benthic-macroinvertebrate bioassessments and sedimentation/siltation, and the Rito de los Frijoles is impaired for HQCF and primary- and secondary-contact recreation from elevated DDT concentrations, fecal coliform counts, water temperature, and turbidity levels. The probable sources of impairment in these canyons are sediment runoff following forest fires, natural sediment sources, recreational activities, and chemical spills (State of New Mexico, 2004). All waterbodies in the Tsankawi unit are on the 303(d) list: Sandia Canyon for not supporting wildlife habitat from PCBs; Los Alamos Canyon for not supporting livestock watering and wildlife habitat from elevated gross alpha counts and selenium concentrations; and Pueblo Canyon for not supporting livestock watering and wildlife habitat from elevated gross alpha counts and concentrations of selenium and mercury. The probable sources of impairment for these canyons include improper waste disposal, the presence of hazardous waste sites, atmospheric deposition, erosion and sedimentation from upland development, natural geologic sources, and runoff from fires (State of New Mexico, 2004).

Additional water-resources issues identified by the I\&M Program include residues from the application of organochlorine pesticides near the headquarters area in the 1950s and 1960s; effects of sedimentation on benthic macroinvertebrate populations in Capulin Creek; ecological effects from inundation by Cochiti Lake; large-scale wildfire effects; water-quality degradation from land disturbance activities outside the park boundary; and effects of road salt and cindering activities on State Highway 4 on the Rito de los Frijoles (Thomas and others, 2006). Visitor effects, internal park development, and trespass livestock and wildlife (elk and deer) over-browsing riparian vegetation are additional concerns (McGarigle, 1998; Mott, 1999; Thomas and others, 2006). Despite the numerous water-quality concerns, the monument's watershed is considered one of its most valuable resources (Thomas and others, 2006).

\section{Available Water-Quality Data}

Water-quality data for 35 sites within the monument boundary were compiled in the SCPN water-quality database, including data for 28 stream sites, 6 springs, and 1 reservoir site. Additional data for the areas upstream and surrounding BAND also were compiled during the database compilation effort, including data for 520 stream sites (including sites from the Rio Grande and Los Alamos Canyon), 128 water wells, 51 lake sites (including Cochiti Lake sites), 42 springs, 10 outfalls, and 2 mines. The BAND sites further discussed in this report include only 29 stream sites (site 721 is upstream from the park boundary) on Alamo Creek, Capulin Creek, and the Rito de los Frijoles, and 4 springs, including Apache, Basalt, Frijoles, and Turkey Springs (fig. 2, table 6).

Most of the historical and recent water samples from Alamo Creek, Capulin Creek, and the Rito de los Frijoles (approximately 75 percent) were collected by the NPS; however, the USGS, USFS, and NMED also collected samples in these canyons. The NPS collected surface-water-quality data as early as 1977 in Alamo and Capulin Creeks and as early as 1957 in the Rito de los Frijoles. The NMED is the only agency that collected water-quality data since 1996, when they sampled all three canyons in 2001. The relative temporal distribution of water samples from sites with available data is illustrated in figure 3 . The Rito de los Frijoles has the longest period of record and the largest number of sites with historical water-quality data in BAND. Samples were collected most frequently in June, July, and August.

Sixty-seven samples were collected from three sites in Alamo Creek (sites 719, 721, and 834; fig. 2; table 6) between 1977 and 2001; most data were collected by the NPS in 1977 (11 samples) following the La Mesa Fire and during a concentrated sampling effort (22 samples) in 1983 (fig. 3). Site 834 is the most frequently and recently sampled site with 56 samples collected over the period 1977 to 2001.

Six sites on Capulin Creek (sites 310, 313, 314, 835, 5590, and 5591; fig. 2; table 6) were sampled by the NPS and NMED between 8 and 85 times from 1977 to 2001 for a total of 155 samples (fig. 3). Sites 310 (Upper Capulin Creek at Bandelier/USFS boundary) and 5591 (Capulin Creek at Base Camp gaging station) had the longest periods of record with samples collected 29 and 85 times, respectively, at various intervals between 1977 and 1992. No water-quality data exist for Capulin Creek downstream from the Ranger Base Cabin (site 313) and old Horse Corral area (near site 314) in the monument (fig. 2). Concentrated sampling efforts occurred in 1983 (site 5591) and 1987 (sites 310 and 5591) with 22 samples collected each of these years in the canyon.

Twenty sites on the Rito de los Frijoles were variously sampled between 1 and 289 times from 1957 to 2001, resulting in 896 samples (fig. 3). Lower Frijoles Creek at Headquarters gaging station (site 319 , fig. 2; table 6) had the longest period of record, with 289 samples collected by the NPS from 1957 to 1964 and from 1971 to 1992 . Most water-quality samples for the Rito de los Frijoles were collected in the upper reaches, or Upper Frijoles Creek (at and upstream from site 5576), and in the lower reaches, or Lower Frijoles Creek, of the canyon (at and downstream from site 331).

The relative temporal distribution of water samples from the evaluated springs is illustrated in figure 4 . Between 36 and 40 samples each were collected by the NPS and USGS at Basalt (site 303), Turkey (site 304), Apache (site 305), and Frijoles (site 556) Springs between 1951 and 1998. For these four springs, a total of 151 samples have been collected.

Information on more than 500 field properties or constituents is available for BAND and includes data from water, bed-sediment, suspended-sediment, and fish-tissue samples. A subset of these data is presented in this report for the selected surface-water canyon and spring sites (Alamo and Capulin Creeks, the Rito de los Frijoles, and Apache, Basalt, Frijoles, and Turkey Springs). The field properties and constituents considered for this report include dissolved oxygen, $\mathrm{pH}$, specific conductance, major ions, nutrients, selected organic compounds and pesticides, selected trace 


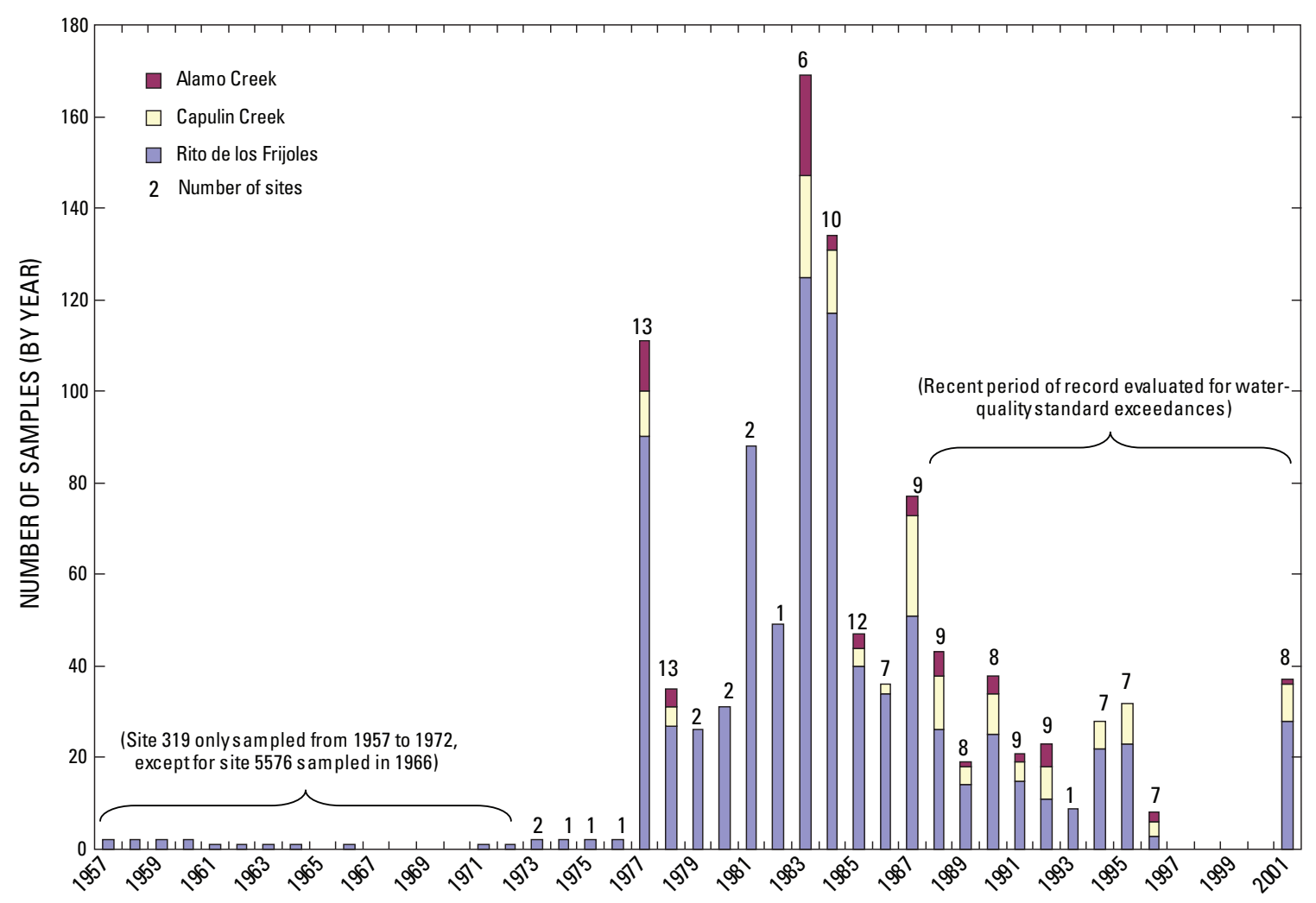

Figure 3. Water sample counts, number of sites, and period of record for Alamo Creek, Capulin Creek, and the Rito de los Frijoles in Bandelier National Monument, New Mexico, 1957 to 2001.

elements (arsenic, barium, cadmium, chromium, copper, iron, lead, manganese, mercury, selenium, silver, uranium, and zinc), suspended sediment (or turbidity as a surrogate), and fecal coliform bacteria.

Most of the data for the evaluated surface-water and spring sites are values of field properties and concentrations of major ions and nutrients. Selected trace elements were sampled between 1 and 29 times at 21 surface-water and spring sites. Radiological constituents were analyzed in one sample from Basalt Spring (site 303). Various organic, pesticide, and (or) wastewater compounds were analyzed once or twice in samples from the Rito de los Frijoles (sites 330, 836, and 837) and from Basalt Spring (site 303), including phenol and alkylbenzene sulfonate (ABS). Samples analyzed for suspended sediment were collected 146 times from 22 surfacewater and spring sites; turbidity was measured 349 times from 18 surface-water and spring sites (excluding Basalt Spring). Samples analyzed for fecal coliform bacteria were collected 38 times from 11 surface-water sites; no samples from springs were analyzed for microorganisms.

Selected sites on Alamo Creek (site 834), Capulin Creek (sites 313, 314, and 5590), and on the Rito de los Frijoles (sites 307, 308, 315, 316, and 317) were measured for instantaneous streamflow, daily discharge, and (or) stream stage. Most of the available instantaneous flow data (195 measurements) are from site 307 , which is near the visitor center in the Rito de los Frijoles drainage, whereas only between one and eight flow measurements were made at all other surface-water sites in the monument. Flow was measured at Basalt Spring (site 303) 19 times.

\section{Characterization of Water Quality}

\section{Surface-Water Quality}

Water-quality data summaries for selected sites on Alamo Creek are provided in table 7, for Capulin Creek in table 8, and for the Rito de los Frijoles (Upper and Lower Frijoles Creek) in table 9. The sites in and upstream from the monument boundary are primarily within the Bandelier Tuff with selected headwater sites flowing through intermediate to siliceous volcanic rocks and (or) the Santa Fe Group (arkosic siltstone and sandstone with clay and pebbly conglomerate), which overlie the Bandelier Tuff, and a few sites near the confluence of the canyon streams with the Rio Grande flowing through the underlying basaltic and andesitic lava flows. 


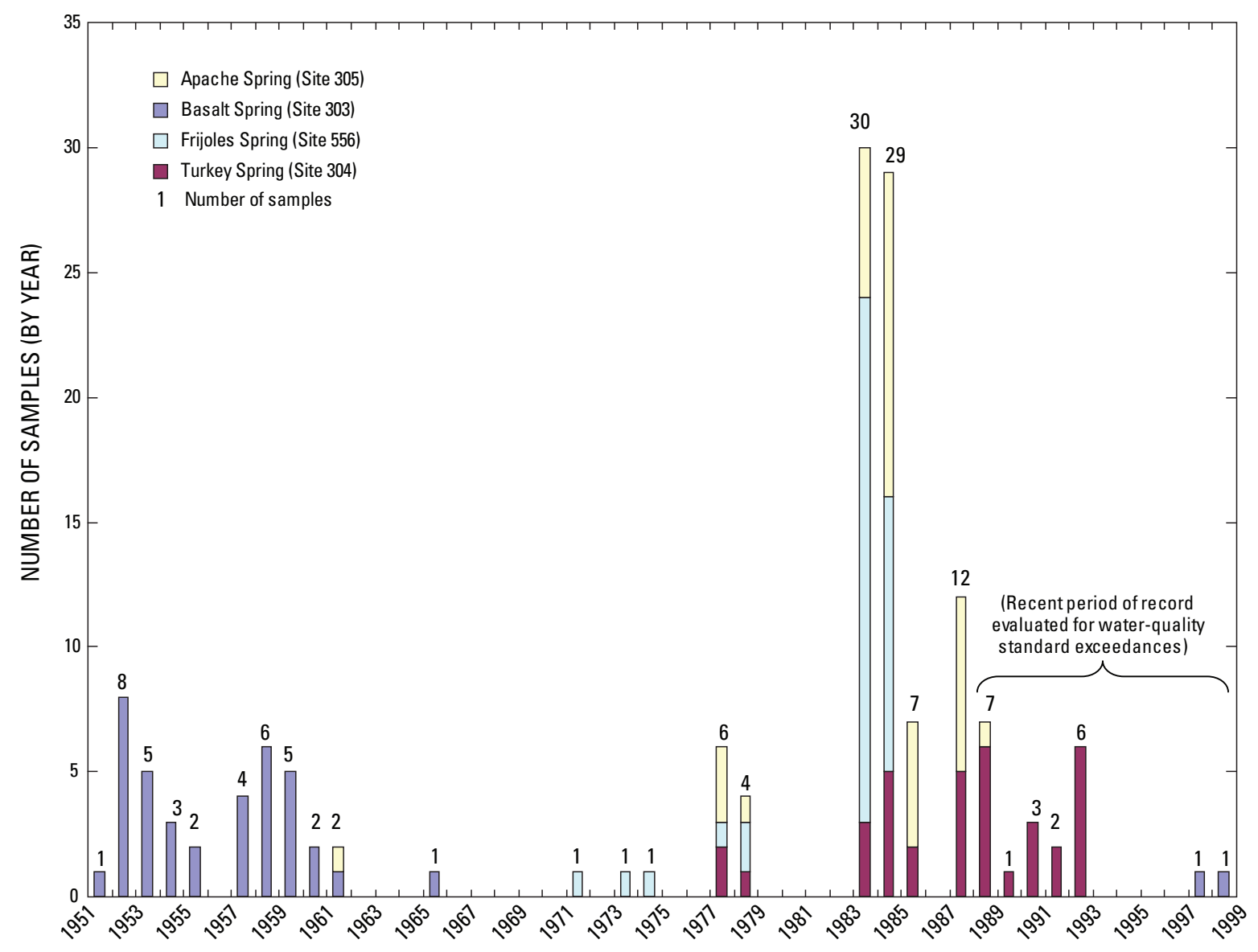

Figure 4. Water sample counts and period of record of Apache, Basalt, Frijoles, and Turkey Springs in Bandelier National Monument, New Mexico, 1951 to 1998.

\section{Field Properties}

Acid neutralizing capacity values ranged from 16.3 to 262 milligrams per liter as calcium carbonate $(\mathrm{mg} / \mathrm{L}$ as $\mathrm{CaCO}_{3}$ ) for sites in Alamo Creek, Capulin Creek, and the Rito de los Frijoles (tables 7, 8, and 9). Generally these waters are neither strongly acidic nor basic and have median ANC values ranging from 35.4 to $56.1 \mathrm{mg} / \mathrm{L}$ as $\mathrm{CaCO}_{3}$ for all three creeks. Concentrations are similar to those measured in the monument's springs. ANC generally decreases with increasing streamflow.

Dissolved oxygen values ranged from 2.7 to $14.3 \mathrm{mg} / \mathrm{L}$ in Alamo Creek, Capulin Creek, and the Rito de los Frijoles (tables 7, 8, and 9). From data collected since 1988, six DO measurements from five sites on Capulin Creek and one DO measurement on the Rito de los Frijoles (site 315) were below the New Mexico Water Quality Control Commission (NMWQCC) HQCF minimum standard of $6 \mathrm{mg} / \mathrm{L}$. Historical data indicate some sites on Alamo Creek, Capulin Creek, and the Rito de los Frijoles have periodically experienced reduced DO conditions, which could be related to one or more factors, including elevated concentrations of nutrients, turbidity levels, water temperature, or salinity, as well as the time of day the samples were collected. There was not a consistent pattern between these water-quality properties and constituents and the low DO measurements to explain the reduced DO conditions.

Measurements of $\mathrm{pH}$ ranged from 5.4 to 9 standard units (SU) in Alamo Creek, Capulin Creek, and the Rito de los Frijoles (tables 7, 8, and 9). Median values were between 7.4 and 7.57 SU for the three creeks. Two recent (since 1988) $\mathrm{pH}$ values for site 5591 in Capulin Creek and eight recent $\mathrm{pH}$ values for sites in Upper (sites 322 and 323) and Lower Frijoles Creek (sites 318,319, and 320) were below the acceptable $6.6 \mathrm{SU}$ (minimum) for an HQCF, as defined by the NMWQCC. One $\mathrm{pH}$ value in Alamo Creek was measured at 6.6 SU (site 834) in June 1990, which is equal to the State's low pH standard.

Specific conductance measurements ranged from 11 to 710 microsiemens per centimeter $(\mu \mathrm{S} / \mathrm{cm})$ in Alamo Creek, Capulin Creek, and the Rito de los Frijoles (tables 7, 8, and 9). In Alamo Creek one historical measurement of $675 \mu \mathrm{S} / \mathrm{cm}$, 
Table 7. Statistical summary of water-quality data and exceedances of water-quality standards at selected Alamo Creek sampling sites located in and upstream from Bandelier National Monument, New Mexico, 1977 to 2001.

[ABS, alkylbenzene sulfonate; AL, aquatic life; ANC, acid neutralizing capacity; col/100 mL, colonies per 100 milliliters; DWS, domestic-water supply; EPA RC II, U.S. Environmental Protection Agency National Recommended Nutrient Criteria for Ecoregion II; fil, filtered; fts, cubic feet per second; GM, geometric mean; HQCF, high quality cold-water fishery; H, high (maximum) standard; I, instantaneous; L, low (minimum) standard; mg/L, milligrams per liter; N, nitrogen; NAWQ, National Ambient Water Quality standard; NMWQCC, New Mexico Water Quality Control Commission; No., number; NTU, nephelometric turbidity units; P, phosphorus; PC, primary contact recreation; POR, period of record; rec, recoverable; SU, standard units; TVS, table value standard; unfil, unfiltered; $\mu \mathrm{S} / \mathrm{cm}$, microsiemens per centimeter; <, less than; --, not available or not computed; bold type indicates exceedance during recent POR]

\begin{tabular}{|c|c|c|c|c|c|c|c|}
\hline \multirow[b]{2}{*}{$\begin{array}{l}\text { Alamo Creek } \\
\text { sites } \\
\text { (see figure } 2 \\
\text { for location } \\
\text { of sites) }\end{array}$} & \multirow[b]{2}{*}{$\begin{array}{c}\text { Field property } \\
\text { or } \\
\text { constituent } \\
\text { (reporting units) }\end{array}$} & \multicolumn{4}{|c|}{$\begin{array}{c}\text { Complete POR } \\
1977 \text { to } 2001^{1}\end{array}$} & \multicolumn{2}{|c|}{$\begin{array}{l}\text { Recent POR } \\
1988 \text { to } 2001^{2}\end{array}$} \\
\hline & & $\begin{array}{l}\text { No. of } \\
\text { analyses/ } \\
\text { No. of } \\
\text { censored } \\
\text { values }\end{array}$ & $\begin{array}{l}\text { Minimum } \\
\text { value }\end{array}$ & $\begin{array}{l}\text { Median } \\
\text { value }\end{array}$ & $\begin{array}{l}\text { Maximum } \\
\text { value }\end{array}$ & $\begin{array}{l}\text { NMWQCC } \\
\text { standard or } \\
\text { Federal } \\
\text { criteria } \\
\text { (Use) }^{3}\end{array}$ & $\begin{array}{l}\text { No. of standard } \\
\text { exceedances/ } \\
\text { No. of analyses/ } \\
\text { No. of sites with } \\
\text { exceedances }\end{array}$ \\
\hline${ }^{4} 719,721$, and 834 & $\mathrm{ANC}(\mathrm{mg} / \mathrm{L} \mathrm{CaCO})_{3}$ & $20 / 0$ & 20.7 & 43.4 & 95 & -- & -- \\
\hline 719 and 834 & Dissolved oxygen (mg/L) & $20 / 0$ & 4.24 & 7.91 & 9.27 & $\begin{array}{c}6 \\
(\mathrm{HQCF})\end{array}$ & $0 / 13 / 0$ \\
\hline 719,721 , and 834 & $\mathrm{pH}(\mathrm{SU})$ & $60 / 0$ & 6.6 & 7.46 & 8.5 & $\begin{array}{c}8.8, \mathrm{H} \\
6.6, \mathrm{~L} \\
(\mathrm{HQCF})\end{array}$ & $\begin{array}{l}\text { 0/19/0, L } \\
0 / 19 / 0, \mathrm{H}\end{array}$ \\
\hline 834 & Streamflow $\left(\mathrm{ft}^{3} / \mathrm{s}\right)$ & $1 / 0$ & 0.43 & 0.43 & 0.43 & -- & -- \\
\hline 719 and 834 & Turbidity (NTU) & $14 / 0$ & 2.6 & 5.6 & 11 & $\begin{array}{c}25, \mathrm{H} \\
10, \mathrm{~L} \\
(\mathrm{HQCF})\end{array}$ & $\begin{array}{l}0 / 14 / 0, \mathrm{H} \\
\mathbf{1 / 1 4 / 1}, \mathbf{L}\end{array}$ \\
\hline 719,721 , and 834 & $\begin{array}{l}\text { Water temperature } \\
\text { (degrees Celsius) }\end{array}$ & $61 / 0$ & 4 & 13 & 28 & $\begin{array}{c}20 \\
(\mathrm{HQCF})\end{array}$ & $0 / 19 / 0$ \\
\hline \multicolumn{8}{|c|}{ Nutrients (aggregated) ${ }^{5}(1977-1996)$} \\
\hline 834 & $\begin{array}{l}\text { Ammonia, unfiltered } \\
(\mathrm{mg} / \mathrm{L} \text { as } \mathrm{N})\end{array}$ & $1 / 0$ & .140 & .140 & .140 & TVS (AL) & $0 / 1 / 0$ \\
\hline \multicolumn{8}{|c|}{ Other constituents (1977-1996) } \\
\hline 834 & $\begin{array}{l}\text { Fecal coliform } \\
\text { (col/100 mL) }\end{array}$ & $1 / 0$ & 23 & 23 & 23 & $\begin{array}{c}\text { 200, GM } \\
400, \mathrm{I} \\
\text { (PC) }\end{array}$ & -- \\
\hline 719 & ABS, unfil rec (mg/L) & $1 / 1$ & $<.005$ & $<.005$ & $<.005$ & -- & -- \\
\hline 719 & Phenols (mg/L) & $3 / 2$ & $<.001$ & -- & .002 & -- & -- \\
\hline
\end{tabular}


Table 7. Statistical summary of water-quality data and exceedances of water-quality standards at selected Alamo Creek sampling sites located in and upstream from Bandelier National Monument, New Mexico, 1977 to 2001.-Continued

[ABS, alkylbenzene sulfonate; AL, aquatic life; ANC, acid neutralizing capacity; col/100 mL, colonies per 100 milliliters; DWS, domestic-water supply; EPA RC II, U.S. Environmental Protection Agency National Recommended Nutrient Criteria for Ecoregion II; fil, filtered; ft ${ }^{3} / \mathrm{s}$, cubic feet per second; GM, geometric mean; HQCF, high quality cold-water fishery; H, high (maximum) standard; I, instantaneous; L, low (minimum) standard; mg/L, milligrams per liter; N, nitrogen; NAWQ, National Ambient Water Quality standard; NMWQCC, New Mexico Water Quality Control Commission; No., number; NTU, nephelometric turbidity units; P, phosphorus; PC, primary contact recreation; POR, period of record; rec, recoverable; SU, standard units; TVS, table value standard; unfil, unfiltered; $\mu \mathrm{S} / \mathrm{cm}$, microsiemens per centimeter; <, less than; --, not available or not computed; bold type indicates exceedance during recent POR]

\begin{tabular}{|c|c|c|c|c|c|c|c|}
\hline \multirow[b]{2}{*}{$\begin{array}{l}\text { Alamo Creek sites } \\
\text { (see figure } 2 \text { for } \\
\text { location of sites) }\end{array}$} & \multirow[b]{2}{*}{$\begin{array}{l}\text { Field property or } \\
\text { constituent } \\
\text { (reporting units) }\end{array}$} & \multicolumn{4}{|c|}{$\begin{array}{c}\text { Complete POR } \\
1977 \text { to } 2001^{1}\end{array}$} & \multicolumn{2}{|c|}{$\begin{array}{l}\text { Recent POR } \\
1988 \text { to } 2001^{2}\end{array}$} \\
\hline & & $\begin{array}{l}\text { No. of } \\
\text { analyses/ } \\
\text { No. of } \\
\text { censored } \\
\text { values }\end{array}$ & $\begin{array}{l}\text { Minimum } \\
\text { value }\end{array}$ & $\begin{array}{c}\text { Median } \\
\text { value }\end{array}$ & $\begin{array}{l}\text { Maximum } \\
\text { value }\end{array}$ & $\begin{array}{l}\text { NMWOCC } \\
\text { standard or } \\
\text { Federal } \\
\text { criteria } \\
(\text { Use })^{3}\end{array}$ & $\begin{array}{c}\text { No. of } \\
\text { standard } \\
\text { exceedances/ } \\
\text { No. of analyses/ } \\
\text { No. of sites with } \\
\text { exceedances }\end{array}$ \\
\hline 719 & Iron, unfil & $3 / 2$ & $<500$ & -- & 620 & $\begin{array}{l}1,000 \text { fil } \\
\text { (NAWQ) }\end{array}$ & -- \\
\hline 719 & Lead, unfil rec & $3 / 3$ & $<25$ & -- & $<30$ & $\begin{array}{l}\text { TVS fil } \\
\text { (AL) }\end{array}$ & -- \\
\hline 719 & Zinc, unfil rec & $3 / 2$ & $<500$ & -- & 58 & $\begin{array}{l}\text { TVS fil } \\
\text { (AL) }\end{array}$ & \\
\hline
\end{tabular}

${ }^{1}$ All available data considered from 1977 to 2001 ; POR varies with constituent and site.

${ }^{2}$ Last 15 years of available data considered for standards exceedance analysis (that is, all samples collected on or after January 1, 1988 through December 31, 2003). At the time of data compilation there were no available data from the source databases collected at these selected sites after 2001. POR varies with constituent and site.

${ }^{3}$ State standards and designated beneficial uses from the New Mexico Water Quality Control Commission (2002). Selected Federal criteria are used when State standards are not established, including the USEPA National Recommended Nutrient Criteria for Ecoregions II and III (U.S. Environmental Protection Agency, 2002), the National Ambient Water Quality Criteria (NAWQ), or the secondary chronic Tier II values (Suter and Tsao, 1996).

${ }^{4}$ Alamo Canyon sites includes sites 721 (in headwaters upstream from monument boundary) and 834 (at upstream monument boundary), and site 719 located downstream near the confluence with the Rio Grande (see fig. 2).

${ }^{5}$ Aggregated nutrients based on Mueller and others (1995); where sample fraction not stated, aggregation includes both filtered and unfiltered concentrations. Zero values were excluded unless converted to a value of less than the censoring level. 
Table 8. Statistical summary of water-quality data and exceedances of water-quality standards at selected Capulin Creek sampling sites located in Bandelier National Monument, New Mexico, 1977 to 2001.

[AL, aquatic life; ANC, acid neutralizing capacity; col/100 mL, colonies per 100 milliliters; DWS, domestic-water supply; EPA RC II, U. S. Environmental Protection Agency National Recommended Nutrient Criteria for Ecoregion II; fil, filtered; $\mathrm{ft}^{3} / \mathrm{s}$, cubic feet per second; GM, geometric mean; HQCF, high quality cold-water fishery; H, high (maximum) standard; I, instantaneous; L, low (minimum) standard; mg/L, milligrams per liter; N, nitrogen; NAWQ, National Ambient Water Quality standard, NMWQCC, New Mexico Water Quality Control Commission; No., number; NTU, nephelometric turbidity units; P, phosphorus; PC, primary contact recreation; POR, period of record; rec, recoverable; SU, standard units; TVS, table value standard; unfil, unfiltered; $\mu \mathrm{S} / \mathrm{cm}$, microsiemens per centimeter; <, less than; --, not available or not computed; bold type indicates exceedance during recent POR]

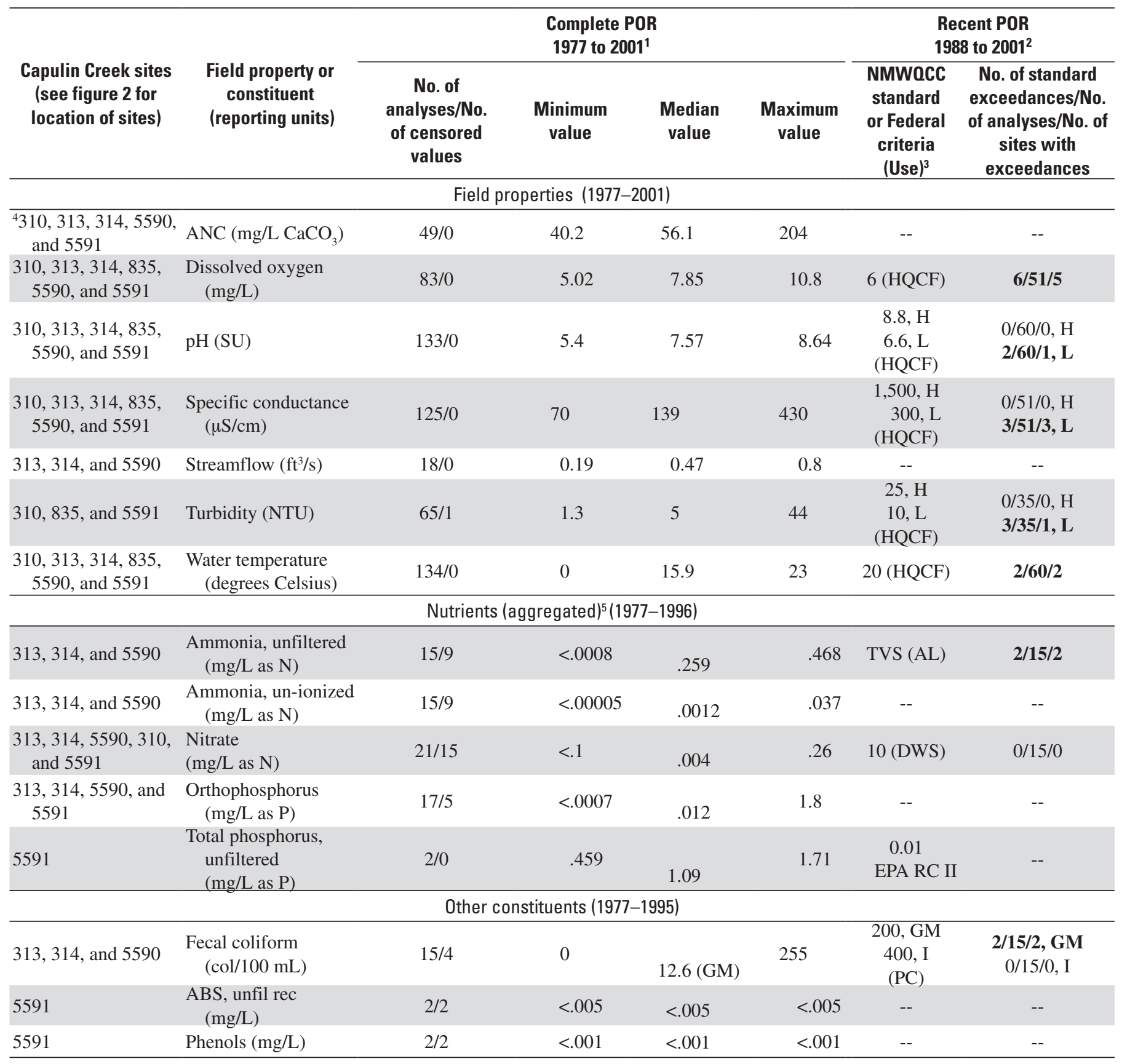


Table 8. Statistical summary of water-quality data and exceedances of water-quality standards at selected Capulin Creek sampling sites located in Bandelier National Monument, New Mexico, 1977 to 2001.-Continued

[AL, aquatic life; ANC, acid neutralizing capacity; col/100 mL, colonies per 100 milliliters; DWS, domestic-water supply; EPA RC II, U. S. Environmental Protection Agency National Recommended Nutrient Criteria for Ecoregion II; fil, filtered; $\mathrm{ft}^{3} / \mathrm{s}$, cubic feet per second; GM, geometric mean; HQCF, high quality cold-water fishery; H, high (maximum) standard; I, instantaneous; L, low (minimum) standard; mg/L, milligrams per liter; N, nitrogen; NAWQ, National Ambient Water Quality standard, NMWQCC, New Mexico Water Quality Control Commission; No., number; NTU, nephelometric turbidity units; P, phosphorus; PC, primary contact recreation; POR, period of record; rec, recoverable; SU, standard units; TVS, table value standard; unfil, unfiltered; $\mu \mathrm{S} / \mathrm{cm}$, microsiemens per centimeter; <, less than; --, not available or not computed; bold type indicates exceedance during recent POR]

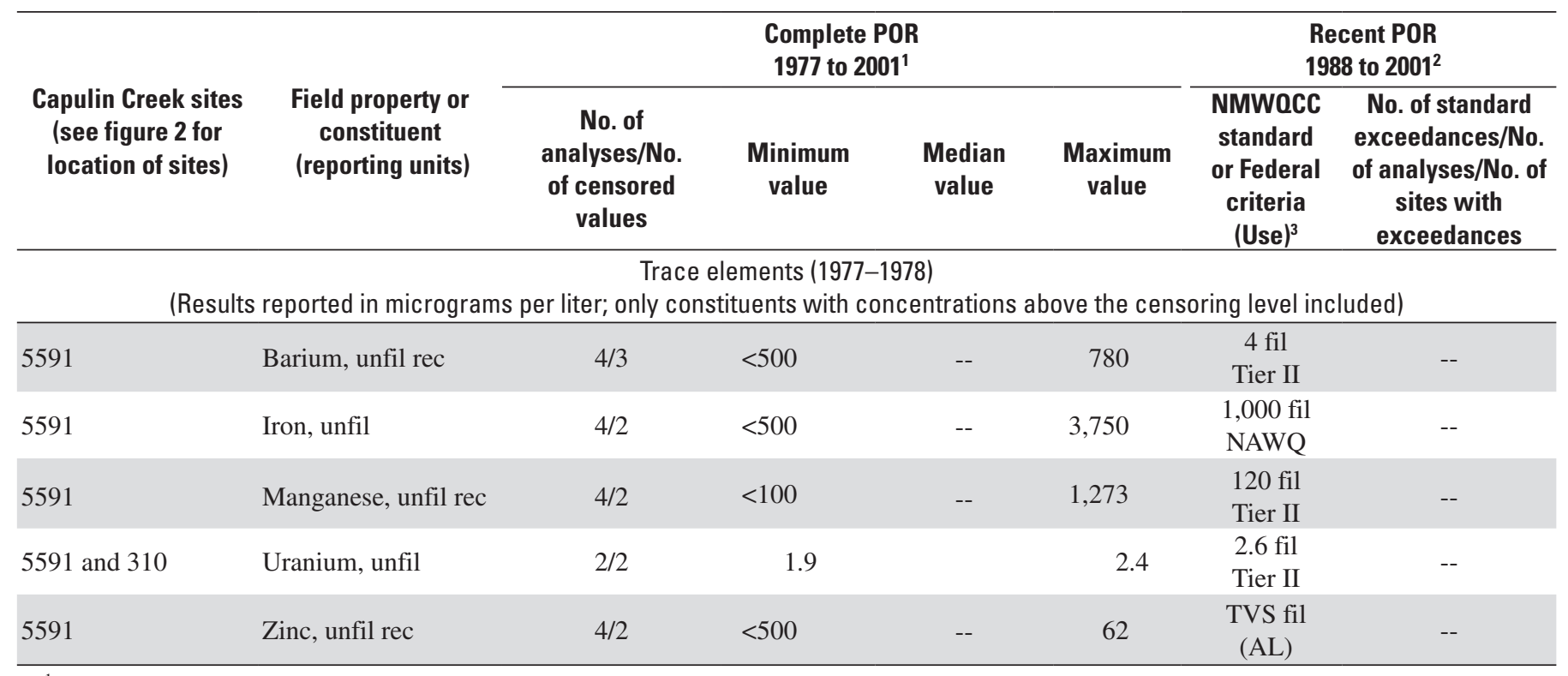

${ }^{1}$ All available data considered from 1977 to 2001 ; POR varies with constituent and site.

${ }^{2}$ Last 15 years of available data considered for standards exceedance analysis (that is, all samples collected on or after January 1, 1988 through December 31, 2003). At the time of data compilation there were no available data from the source databases collected at these selected sites after 2001. POR varies with constituent and site.

${ }^{3}$ State standards and designated beneficial uses from the New Mexico Water Quality Control Commission (2002). Selected Federal criteria are used when State standards are not established, including the USEPA National Recommended Nutrient Criteria for Ecoregions II and III (U.S. Environmental Protection Agency, 2002), the National Ambient Water Quality Criteria (NAWQ), or the secondary chronic Tier II values (Suter and Tsao, 1996).

${ }^{4}$ Capulin Creek sites includes sites 310 (at monument boundary) and 835, gage station site 5591, and sites located downstream from ranger cabin and horse corral, including sites 313 , and 314, and 5590 (see fig. 2).

${ }^{5}$ Aggregated nutrients based on Mueller and others (1995); where sample fraction not stated, aggregation includes both filtered and unfiltered concentrations. Zero values were excluded unless converted to a value of less than the censoring level. 
Table 9. Statistical summary of water-quality data and exceedances of water-quality standards in selected Rito de los Frijoles (Upper and Lower Frijoles Creek) sampling sites located in Bandelier National Monument, New Mexico, 1957 to 2001.

[ABS, alkylbenzene sulfate; AL, aquatic life; ANC, acid neutralizing capacity; $\mathrm{CaCO}_{3}$, calcium carbonate; col/100 mL; colonies per 100 milliliters; DWS, domestic-water supply; EPA RC II, U.S. Environmental Protection Agency National Recommended Nutrient Criteria for Ecoregion II; fil, filtered; GM, geometric mean; HQCF, high quality cold-water fishery; H, high (maximum) standard; I, instantaneous; L, low (minimum) standard; mg/L, milligrams per liter; N, nitrogen; NMWQCC, New Mexico Water Quality Control Commission; No., number; NTU, nephelometric turbidity units; P, phosphorus; PC, primary contact recreation; POR, period of record; rec, recoverable; SU, standard units; TVS, table value standard; unfil, unfiltered; $\mu \mathrm{S} / \mathrm{cm}$, microsiemens per centimeter; $<$, less than; --, not available; bold type indicates exceedance during recent POR]

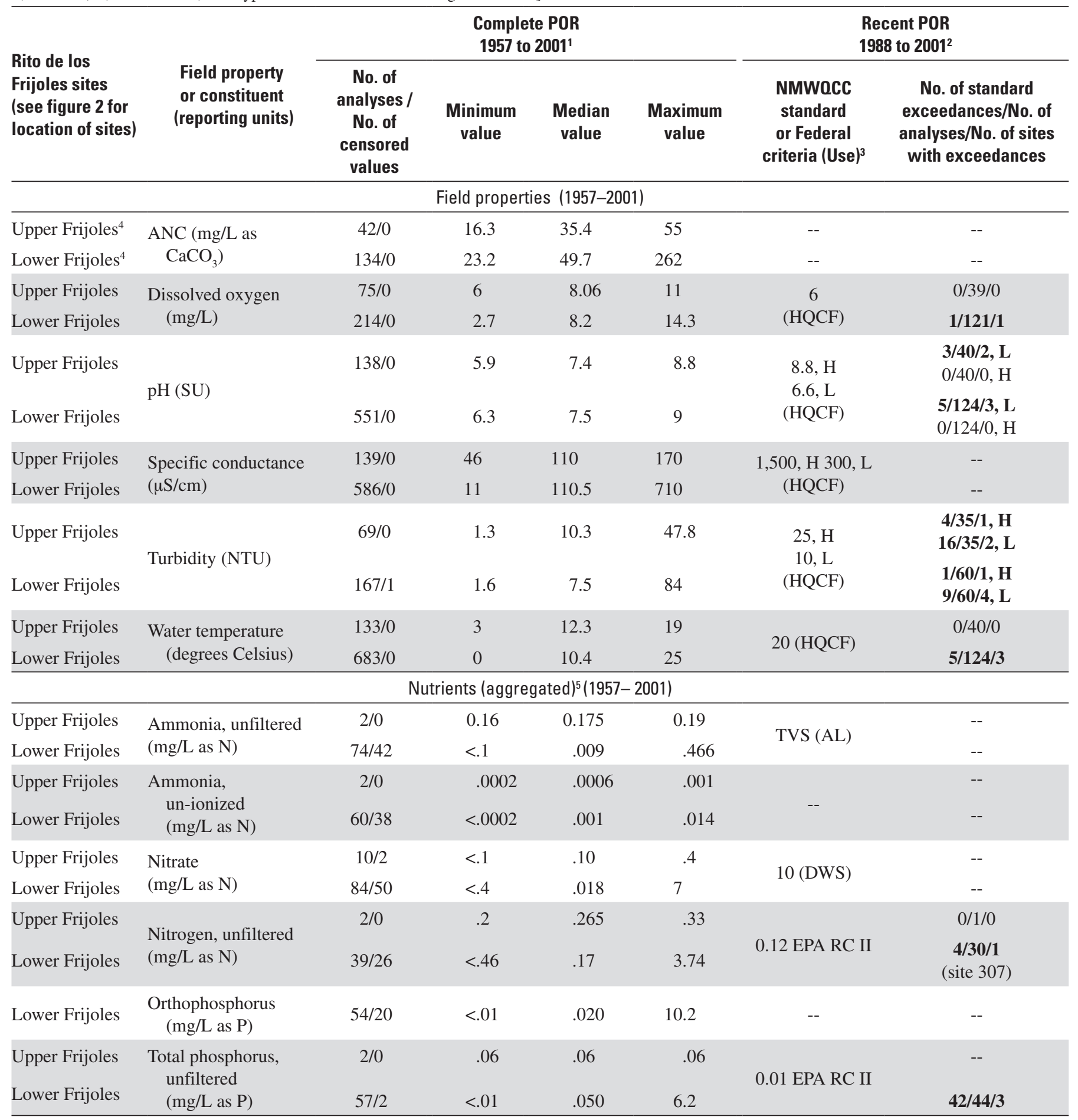


Table 9. Statistical summary of water-quality data and exceedances of water-quality standards in selected Rito de los Frijoles (Upper and Lower Frijoles Creek) sampling sites located in Bandelier National Monument, New Mexico, 1957 to 2001.—Continued

[ABS, alkylbenzene sulfate; $\mathrm{AL}$, aquatic life; $\mathrm{ANC}$, acid neutralizing capacity; $\mathrm{CaCO}_{3}$, calcium carbonate; col/100 mL; colonies per 100 milliliters; DWS, domestic-water supply; EPA RC II, U.S. Environmental Protection Agency National Recommended Nutrient Criteria for Ecoregion II; fil, filtered; GM, geometric mean; HQCF, high quality cold-water fishery; H, high (maximum) standard; I, instantaneous; L, low (minimum) standard; mg/L, milligrams per liter; N, nitrogen; NMWQCC, New Mexico Water Quality Control Commission; No., number; NTU, nephelometric turbidity units; P, phosphorus; PC, primary contact recreation; POR, period of record; rec, recoverable; SU, standard units; TVS, table value standard; unfil, unfiltered; $\mu \mathrm{S} / \mathrm{cm}$, microsiemens per centimeter; $<$, less than; --, not available; bold type indicates exceedance during recent POR]

\begin{tabular}{|c|c|c|c|c|c|c|c|}
\hline \multirow[b]{2}{*}{$\begin{array}{l}\text { Rito de los } \\
\text { Frijoles sites } \\
\text { (see figure } 2 \text { for } \\
\text { location of sites) }\end{array}$} & \multirow[b]{2}{*}{$\begin{array}{l}\text { Field property } \\
\text { or constituent } \\
\text { (reporting units) }\end{array}$} & \multicolumn{4}{|c|}{$\begin{array}{c}\text { Complete POR } \\
1957 \text { to } 2001^{1} \\
\end{array}$} & \multicolumn{2}{|c|}{$\begin{array}{l}\text { Recent POR } \\
1988 \text { to } 2001^{2} \\
\end{array}$} \\
\hline & & $\begin{array}{l}\text { No. of } \\
\text { analyses / } \\
\text { No. of } \\
\text { censored } \\
\text { values } \\
\end{array}$ & $\begin{array}{l}\text { Minimum } \\
\text { value }\end{array}$ & $\begin{array}{l}\text { Median } \\
\text { value }\end{array}$ & $\begin{array}{l}\text { Maximum } \\
\text { value }\end{array}$ & $\begin{array}{c}\text { NMWOCC } \\
\text { standard } \\
\text { or Federal } \\
\text { criteria (Use) }\end{array}$ & $\begin{array}{c}\text { No. of standard } \\
\text { exceedances/No. of } \\
\text { analyses/No. of sites } \\
\text { with exceedances }\end{array}$ \\
\hline Upper Frijoles & Fecal coliform & $1 / 0$ & 2 & 2 & 2 & 200, GM & -- \\
\hline Lower Frijoles & $(\mathrm{col} / 100 \mathrm{~mL})$ & $21 / 3$ & 0 & $30.8(\mathrm{GM})$ & 229 & $\begin{array}{c}400, \mathrm{I} \\
(\mathrm{PC})\end{array}$ & 2/18/2, GM \\
\hline Lower Frijoles & ABS, unfil rec & $3 / 2$ & $<.005$ & -- & .3 & -- & -- \\
\hline Lower Frijoles & $\begin{array}{l}\text { Bis (2-ethylhexyl) } \\
\text { phthalate, unfil rec }\end{array}$ & $4 / 2$ & $<.48$ & -- & 1.38 & $59(\mathrm{AL})$ & $0 / 4 / 0$ \\
\hline Lower Frijoles & $\begin{array}{l}\text { Suspended sediment, } \\
\text { concentration } \\
(\mathrm{mg} / \mathrm{L})\end{array}$ & $194 / 4$ & $<1$ & 22 & 98,800 & -- & -- \\
\hline
\end{tabular}

Trace elements (1971-1995)

(Results reported in micrograms per liter; only constituents with concentrations above the censoring level included; zero values recensored)

\begin{tabular}{|c|c|c|c|c|c|c|c|}
\hline $\begin{array}{l}\text { Upper Frijoles } \\
\text { Lower Frijoles }\end{array}$ & Arsenic, unfil & $\begin{array}{l}1 / 1 \\
7 / 6\end{array}$ & $\begin{array}{l}<5 \\
<1\end{array}$ & $\begin{array}{c}<5 \\
--\end{array}$ & $\begin{array}{l}<5 \\
14\end{array}$ & $\begin{array}{l}150 \text { fil } \\
(\mathrm{AL})\end{array}$ & -- \\
\hline Upper Frijoles & Barium, unfil rec & $1 / 1$ & $<100$ & $<100$ & $<100$ & $\begin{array}{l}4 \text { fil } \\
\text { Tier II }\end{array}$ & -- \\
\hline Upper Frijoles & \multirow{2}{*}{ Cadmium, unfil } & $1 / 1$ & $<1$ & $<1$ & $<1$ & \multirow{2}{*}{$\begin{array}{l}\text { TVS fil } \\
\text { (AL) }\end{array}$} & -- \\
\hline Lower Frijoles & & $6 / 5$ & $<1$ & -- & 2 & & -- \\
\hline \multirow{2}{*}{ Lower Frijoles } & \multirow{2}{*}{$\begin{array}{l}\text { Iron, fil } \\
\text { Iron, unfil rec }\end{array}$} & $29 / 0$ & 73 & 120 & 840 & \multirow{2}{*}{$\begin{array}{l}\text { 1,000 fil } \\
\text { NAWQ }\end{array}$} & $0 / 29 / 0$ \\
\hline & & $9 / 1$ & 360 & 900 & 240,000 & & -- \\
\hline Upper Frijoles & \multirow{2}{*}{ Lead, unfil rec } & $1 / 1$ & $<10$ & $<10$ & $<10$ & \multirow{2}{*}{ TVS fil (AL) } & -- \\
\hline Lower Frijoles & & $12 / 8$ & $<10$ & 3.48 & 1,000 & & -- \\
\hline
\end{tabular}


Table 9. Statistical summary of water-quality data and exceedances of water-quality standards in selected Rito de los Frijoles (Upper and Lower Frijoles Creek) sampling sites located in Bandelier National Monument, New Mexico, 1957 to 2001.—Continued

[ABS, alkylbenzene sulfate; AL, aquatic life; ANC, acid neutralizing capacity; $\mathrm{CaCO}_{3}$, calcium carbonate; col/100 mL; colonies per 100 milliliters; DWS, domestic-water supply; EPA RC II, U.S. Environmental Protection Agency National Recommended Nutrient Criteria for Ecoregion II; fil, filtered; GM, geometric mean; HQCF, high quality cold-water fishery; H, high (maximum) standard; I, instantaneous; L, low (minimum) standard; mg/L, milligrams per liter; N, nitrogen; NMWQCC, New Mexico Water Quality Control Commission; No., number; NTU, nephelometric turbidity units; P, phosphorus; PC, primary contact recreation; POR, period of record; rec, recoverable; SU, standard units; TVS, table value standard; unfil, unfiltered; $\mu \mathrm{S} / \mathrm{cm}$, microsiemens per centimeter; $<$, less than; --, not available; bold type indicates exceedance during recent POR]

\begin{tabular}{|c|c|c|c|c|c|c|c|}
\hline \multirow[b]{2}{*}{$\begin{array}{l}\text { Rito de los } \\
\text { Frijoles sites } \\
\text { (see figure } 2 \text { for } \\
\text { location of sites) }\end{array}$} & \multirow[b]{2}{*}{$\begin{array}{l}\text { Field property } \\
\text { or constituent } \\
\text { (reporting units) }\end{array}$} & \multicolumn{4}{|c|}{$\begin{array}{c}\text { Complete POR } \\
1957 \text { to } 2001^{1}\end{array}$} & \multicolumn{2}{|c|}{$\begin{array}{l}\text { Recent POR } \\
1988 \text { to } 2001^{2}\end{array}$} \\
\hline & & $\begin{array}{l}\text { No. of } \\
\text { analyses / } \\
\text { No. of } \\
\text { censored } \\
\text { values }\end{array}$ & $\begin{array}{l}\text { Minimum } \\
\text { value }\end{array}$ & $\begin{array}{l}\text { Median } \\
\text { value }\end{array}$ & $\begin{array}{l}\text { Maximum } \\
\text { value }\end{array}$ & $\begin{array}{c}\text { NMWQCC } \\
\text { standard } \\
\text { or Federal } \\
\text { criteria (Use) }\end{array}$ & $\begin{array}{c}\text { No. of standard } \\
\text { exceedances/No. of } \\
\text { analyses/No. of sites } \\
\text { with exceedances }\end{array}$ \\
\hline
\end{tabular}

Trace elements (1971-1995)—Continued

(Results reported in micrograms per liter; only constituents with concentrations above the censoring level included; zero values recensored)

\begin{tabular}{|c|c|c|c|c|c|c|c|}
\hline \multirow[b]{2}{*}{ Lower Frijoles } & Manganese, fil & $28 / 0$ & 5 & 9.0 & 21 & \multirow[b]{2}{*}{120 fil Tier II } & $0 / 28 / 0$ \\
\hline & $\begin{array}{c}\text { Manganese, } \\
\text { unfil rec }\end{array}$ & $9 / 3$ & $<100$ & 117 & 14,000 & & -- \\
\hline Lower Frijoles & Mercury, unfil rec & $7 / 7$ & $<.001$ & -- & $<.5$ & $\begin{array}{l}0.012 \text { unfil } \\
\text { (AL) }\end{array}$ & -- \\
\hline Lower Frijoles & Strontium, fil & $2 / 0$ & 48 & 52 & 56 & $\begin{array}{c}1,500 \text { fil } \\
\text { Tier II }\end{array}$ & -- \\
\hline Lower Frijoles & Uranium, unfil & $20 / 14$ & $<1$ & .278 & 6.8 & Tier II & -- \\
\hline Lower Frijoles & Zinc, unfil rec & $10 / 3$ & $<10$ & 62 & 1,200 & TVS fil (AL) & -- \\
\hline
\end{tabular}

${ }^{1}$ All available data considered from 1957 to 2001; POR reflects range for individual sites within this time period.

${ }^{2}$ Last 15 years of available data considered for standards exceedance analysis (that is, all samples collected on or after January 1, 1988 through Decmeber 31, 2003). At the time of data compilation there were no available data from the source databases collected at these selected sites after 2001. Date range varies with constituent.

${ }^{3}$ State standards and designated beneficial uses from the New Mexico Water Quality Control Commission (2002). Selected Federal criteria are used when State standards are not established, including the USEPA National Recommended Nutrient Criteria for Ecoregions II and III (U.S. Environmental Protection Agency, 2002), the National Ambient Water Quality Criteria (NAWQ), or the secondary chronic Tier II values (Suter and Tsao, 1996).

${ }^{4}$ Upper Frijoles includes site 5576 and all sites upstream from it (see fig. 2). Lower Frijoles includes site 331 and all sites downstream from it (see fig. 2).

${ }^{5}$ Aggregated nutrients based on Mueller and others (1995); where sample fraction not stated, aggregation includes both filtered and unfiltered concentrations. Zero values were excluded unless converted to a value of less than the censoring level. 
from site 719, exceeded the NMWQCC low SC standard of $300 \mu \mathrm{S} / \mathrm{cm}$; this value was from a post-La Mesa Fire sample collected in August 1977. In Capulin Creek, the highest individual SC measurements of 420, 420, and $430 \mu \mathrm{S} / \mathrm{cm}$, respectively, were made on July 7, 1996, at sites 313, 314, and 5590, following the April 1996 Dome Fire; these higher values were the only recently measured exceedances of the State's low SC standard. In the Rito de los Frijoles, six historical measurements, ranging from 303 to $710 \mu \mathrm{S} / \mathrm{cm}$ made in July and August 1977 from site 307, exceeded the low SC standard. These elevated SC values were likely related to postfire runoff. Recent (since 1988) SC measurements made in the Rito de los Frijoles did not exceed the State's low or high standards. Specific conductance values were generally more variable in the summer months than they were during the winter months. Specific conductance is influenced by flow and generally decreases with increasing streamflow in the Lower Frijoles.

Turbidity values ranged from 1.3 to 84 nephelometric turbidity units (NTU) in Alamo Creek, Capulin Creek, and the Rito de los Frijoles (tables 7, 8, and 9). In Alamo Creek, one measurement of 11 NTU, made in May 1988, exceeded the NMWQCC HQCF low standard of 10 NTU. In Capulin Creek, three recent (since 1988) measurements exceeded the low turbidity standard. Turbidity is one of the three constituents in the Rito de los Frijoles on the State 303(d) list. Since 1988, 25 measurements made in the Rito de los Frijoles exceeded the low turbidity standard, and 5 measurements exceeded the NMWQCC high turbidity standard of 25 NTU. Measurements collected before 1988 also frequently exceeded these standards in the Rito de los Frijoles. In all three creeks, turbidity measurements are typically highest in the months of March through June during the snowmelt runoff period. No turbidity data were available to assess the effects of fire-related runoff for the sampling events that followed the April 1996 Dome Fire.

Water temperature measurements ranged from 0 to $28^{\circ} \mathrm{C}$ in Alamo Creek, Capulin Creek, and the Rito de los Frijoles (tables 7, 8, and 9). No recent measurements from Alamo Creek exceeded the NMWQCC HQCF standard for water temperature $\left(20^{\circ} \mathrm{C}\right)$; however, four historical measurements made from July to September 1977 at site 719 exceeded this standard following the La Mesa Fire. In Capulin Creek, the HQCF $20^{\circ} \mathrm{C}$ standard was exceeded twice since 1988: one measurement of $22^{\circ} \mathrm{C}$ at site 313 and one measurement of $23^{\circ} \mathrm{C}$ at site 5590, both made in July 1996 following the Dome Fire. Water temperature is one of three properties on the 303(d) list for the Rito de los Frijoles. Water temperature exceeded the HQCF $20^{\circ} \mathrm{C}$ standard for three Lower Frijoles sites (sites 307, 315, and 319) a total of five times between June 1990 and August 1995. These exceedances ranged from 21 to $25^{\circ} \mathrm{C}$. No water temperature standards were exceeded at the Upper Frijoles sites.
Major lons

Runoff, dissolution, and the chemistry of ground water discharging from the volcanic rocks in the canyon are the principal drivers of the concentrations of cations and anions in Alamo Creek, Capulin Creek, and the Rito de los Frijoles. Historical major-ion data for Alamo Creek show that the highest recorded concentrations of filtered chloride and unfiltered calcium, magnesium, and sodium were from the September 1, 1977, sample collected after the La Mesa Fire. Data also are sparse for Capulin Creek with sampling occurring from 1977 to 1978 and from 1994 to 1996 . Review of the Capulin Creek data shows that the highest recorded concentrations of filtered calcium, chloride, magnesium, sodium, and unfiltered sulfate were from the July 1996 sample collected after the Dome Fire. Elevated concentrations of filtered sulfate and unfiltered silica also occurred in the analyses of samples collected following the 1977 La Mesa Fire from Capulin Creek. Elevated historical concentrations of unfiltered calcium, magnesium, nitrate, silica, sodium, sulfate, and filtered chloride are associated with the postfire intensive sampling events that occurred in the Rito de los Frijoles in July 1977 and in June and July 1978. This intensive sampling effort captured runoff from the fire-affected headwaters of the canyon; the elevated concentrations likely reflect the increased contribution of sediment associated with the increased runoff following the fire.

Water type in Alamo Creek, Capulin Creek, and the Rito de los Frijoles can be described as calcium bicarbonate with some magnesium, potassium, sodium, sulfate, and minor contributions of chloride, fluoride and nitrate based on a trilinear (Piper) diagram analysis of available data (fig. 5). This concurs with the Purtymun and Adams (1980) description of water-quality conditions in the canyons as calcium bicarbonate. The geology, dominated by the Bandelier Tuff, contributes to the concentrations of cations and anions measured in the canyons' surface waters.

\section{Nutrients}

Selected available nutrient data for ammonia (unfiltered and un-ionized), nitrate (filtered and unfiltered), total nitrogen (unfiltered), orthophosphorus (filtered and unfiltered), and total phosphorus (unfiltered) are summarized in tables 7, 8, and 9, for Alamo Creek, Capulin Creek, and the Rito de los Frijoles, respectively. In Alamo Creek, samples were collected only one or two times for analysis of unfiltered ammonia, orthophosphorus, and total phosphorus and eight times (two or three times at each site) for analysis of nitrate. In Capulin Creek, samples were collected between 2 and 21 times for analysis of ammonia (unfiltered and un-ionized), nitrate, orthophosphorus, and total phosphorus. Samples were analyzed for ammonia (unfiltered and un-ionized), nitrate, total nitrogen, orthophosphorus, and total phosphorus between 2 and 10 times from sites in the Upper Frijoles and between 39 and 84 times from sites in the Lower Frijoles. 


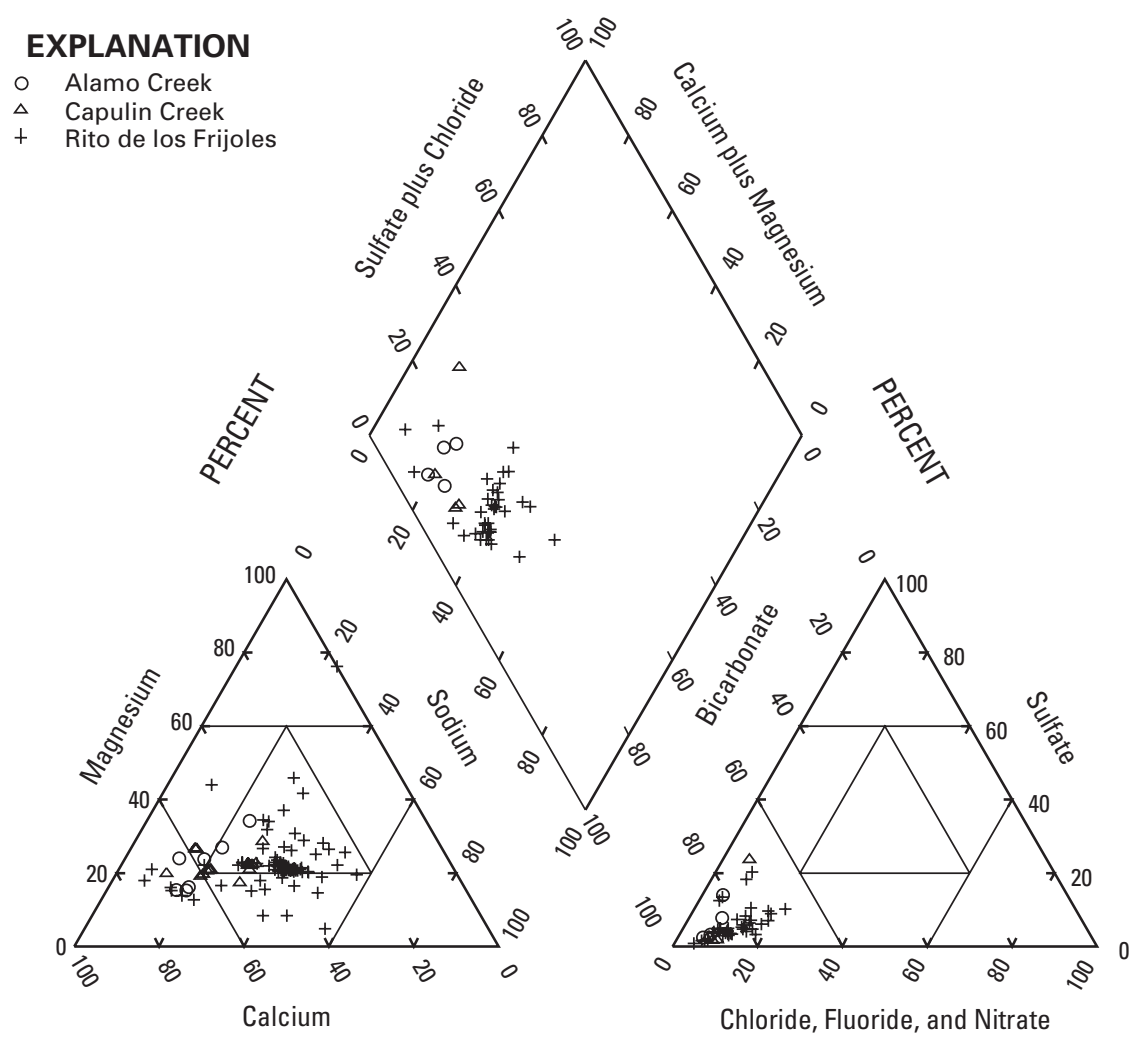

PERCENTAGE OF TOTAL MILLIEQUIVALENTS PER LITER

Figure 5. Water types for Alamo Creek, Capulin Creek, and the Rito de los Frijoles in Bandelier National Monument, New Mexico, 1957 to 2001.

Unfiltered ammonia was measured in a sample from Alamo Creek just one time-at a concentration of $0.140 \mathrm{mg} / \mathrm{L}$ - and ranged from less than 0.0008 to $0.468 \mathrm{mg} / \mathrm{L}$ in Capulin Creek and from less than 0.1 to $0.466 \mathrm{mg} / \mathrm{L}$ in the Rito de los Frijoles. Capulin Creek exceeded the NMWQCC $\mathrm{pH}$ and temperature-based TVS for unfiltered ammonia twice in July 1996 out of 15 samples (once each from sites 313 and 5590); Alamo Creek and the Rito de los Frijoles did not exceed their computed TVS. Unfiltered ammonia concentrations were highest in August 1995 and July 1996 in Capulin Creek and the Rito de los Frijoles. Un-ionized ammonia concentrations ranged from less than 0.00005 to $0.037 \mathrm{mg} / \mathrm{L}$ in Capulin Creek for 15 samples and from less than 0.0002 to $0.014 \mathrm{mg} / \mathrm{L}$ in the Rito de los Frijoles for 62 samples. Unionized ammonia is not regulated in the State of New Mexico.

Eight samples were collected for analysis of nitrate (filtered and unfiltered) from Alamo Creek (7 in 1977 and 1978 and 1 in 1996) and concentrations ranged from less than 0.1 to $0.32 \mathrm{mg} / \mathrm{L} ; 21$ from Capulin Creek and concentrations ranged from less than 0.1 to $0.26 \mathrm{mg} / \mathrm{L}$; and 94 from the Rito de los Frijoles (10 samples from the Upper Frijoles and 84 samples from the Lower Frijoles) and concentrations ranged from less than 0.1 to $7 \mathrm{mg} / \mathrm{L}$. The high nitrate concentration of $7 \mathrm{mg} / \mathrm{L}$ was measured in a sample collected in March 1978 from site 319 and may be related to postfire runoff. All of the historical and recent nitrate values were below the NMWQCC drinking-water standard of $10 \mathrm{mg} / \mathrm{L}$.

Total nitrogen (unfiltered) was measured only in samples collected from the Rito de los Frijoles. Concentrations ranged from less than 0.46 to $3.74 \mathrm{mg} / \mathrm{L}$, though they were generally less than $0.7 \mathrm{mg} / \mathrm{L}$. The high value of $3.74 \mathrm{mg} / \mathrm{L}$ was measured in a June 1985 sample from site 330. No State standards for total nitrogen exist in New Mexico; however, the total nitrogen concentrations exceeded the USEPA-recommended nutrient criteria of $0.12 \mathrm{mg} / \mathrm{L}$ for Ecoregion II four times out of 30 analyses of samples collected from site 307 since 1988 (U.S. Environmental Protection Agency, 2002).

Orthophosphorus was measured in samples from Alamo Creek twice, at concentrations of 0.134 and $0.193 \mathrm{mg} / \mathrm{L} ; 17$ times in samples from Capulin Creek and concentrations ranged from less than 0.0007 to $1.8 \mathrm{mg} / \mathrm{L}$; and 54 times in samples from Lower Frijoles Creek and concentrations ranged from less than 0.01 to $10.2 \mathrm{mg} / \mathrm{L}$. Total phosphorus (unfiltered) was measured once in a 1977 sample collected from Alamo Creek (from site 719) at a concentration of $0.315 \mathrm{mg} / \mathrm{L}$; twice in Capulin Creek in samples from site 5591 in 1977 at concentrations of 0.459 and $1.71 \mathrm{mg} / \mathrm{L}$; and 59 times between 1977 and 2001 in samples from the Rito de los Frijoles (twice 
in Upper Frijoles and 57 times in Lower Frijoles) and concentrations ranged from less than 0.01 to $6.2 \mathrm{mg} / \mathrm{L}$. No State standards for orthophosphorus or total phosphorus exist in New Mexico. In the Rito de los Frijoles, total phosphorus concentrations exceeded the USEPA-recommended nutrient criterion of $0.01 \mathrm{mg} / \mathrm{L}$ for Ecoregion II 42 times out of 44 analyses of samples collected from sites 307, 330, and 836 since 1988; concentrations ranged from 0.02 to $0.146 \mathrm{mg} / \mathrm{L}$, respectively (U.S. Environmental Protection Agency, 2002). Additionally, total phosphorus concentrations exceeded the $0.01-\mathrm{mg} / \mathrm{L}$ criterion in all three creeks in August and September 1977 and in Upper and Lower Frijoles Creek in June 1985. Elevated phosphorus concentrations may be the result of increased sediment transport and ash from the fire-affected watersheds. Possible sources for elevated orthophosphorus concentrations include erosion of phosphorus-rich minerals in soils, particularly weathered apatite, iron or aluminum phosphates, and plagioclase feldspars, which are commonly associated with basalts and other volcanic rocks (Hem, 1989). Other sources of elevated nutrients in the streams could be from human and animal wastes, surface runoff, recreational activities in the drainage basin, and trespass grazing in the monument.

\section{Other Constituents}

Fecal coliform was one of three constituents that resulted in the Rito de los Frijoles being on the State 303(d) list; however, few recent data are available. Recreational activities, including back-country hiking and trespass grazing in the monument, are potential sources of elevated fecal coliform counts in surface water. No coliform data were collected after 1996 in any of the creeks. In Alamo Creek, one sample collected in 1996 from site 834 was analyzed for fecal coliform; in Capulin Creek, 15 samples (5 samples per site) collected from the downstream sites 313, 314, and 5590 in 1994 and 1995 were analyzed for fecal coliform; in the Rito de los Frijoles, 22 samples were analyzed for fecal coliform (one sample from Upper Frijoles and 21 samples from Lower Frijoles Creek) in 1985, 1994, and 1995. A count of 23 colonies per 100 milliliters (col/100 mL) was measured in samples from Alamo Creek; counts ranged from 0 to 255 col/100 mL in samples from Capulin Creek, and in samples from the Rito de los Frijoles, counts ranged from 0 to 229 col/100 mL (tables 7, 8, and 9). In Capulin Creek, counts from two analyses of coliform (234 and $255 \mathrm{col} / 100 \mathrm{~mL}$ measured in samples from sites 313 and 314, respectively) from a July 1994 sampling event exceeded the NMWQCC $200 \mathrm{col} / 100$ $\mathrm{mL}$ standard for primary-contact recreation, which is based on a geometric mean. Counts from two analyses of coliform in samples collected from the Lower Frijoles (sites 315 and 316) narrowly exceeded the State standard with values of 229 and $208 \mathrm{col} / 100 \mathrm{ml}$, respectively.

Organochlorine pesticides, including DDT, were used in BAND (near the developed park headquarters in the Rito de los Frijoles drainage) and in the surrounding Santa Fe National Forest from the late 1940s into the early 1960s (Scurlock,
1998; Mott, 1999). The State of New Mexico has included the Rito de los Frijoles on the 303(d) list for DDT for many years. As part of the USGS National Water-Quality Assessment Program, fish and sediment were sampled in 1997 in the Rio Grande Valley, including one site on the Rito de los Frijoles below Frijoles Falls (site 308; fig. 2). At this site, the study found a greater number of DDT compounds in the bed sediment (a total DDT concentration of $16.4 \mu \mathrm{g} / \mathrm{kg}$ dry weight) and in whole-body rainbow trout (a total DDT concentration of $173 \mu \mathrm{g} / \mathrm{kg}$ wet weight) that exceeded the minimum reporting level than in samples from other sites (table 10; Carter, 1997). Mott (1999) reported that previous studies found DDT concentrations as high as $164 \mathrm{mg} / \mathrm{L}$ adjacent to Rito de los Frijoles Creek near the heaquarters parking lot.

Few data are available on organic compounds in Alamo and Capulin Creeks. In Alamo Creek, ABS was analyzed once in a sample from site 719, and in Capulin Creek, ABS was analyzed twice in 1977 in samples collected from site 5591. All ABS results were below the censoring level (less than $0.005 \mathrm{mg} / \mathrm{L})$. In Alamo Creek, phenols were analyzed three times in samples from site 719 with a concentration range of less than 0.001 to $0.002 \mathrm{mg} / \mathrm{L}$, and in Capulin Creek phenols (unfiltered) were analyzed four times, in 1977 and 1978, in samples from site 5591 following the La Mesa Fire; all phenol results in Capulin Creek were below the censoring level (less than $0.001 \mathrm{mg} / \mathrm{L}$ ). For analyses of samples from the Rito de los Frijoles, organic compounds and pesticides detected in suspended-sediment and fish-tissue samples are summarized in table 10. Fifteen compounds, four that are DDT degradates, were detected in the bed-sediment samples; four DDT degradates were detected in the fish-tissue samples. Of these compounds, six analyses of sediment samples and three analyses of fish tissue samples had concentrations exceeding one or more pollution potential criteria (table 10). Between June and September 2001, four water samples were collected from sites 330,836 , and 837 and analyzed for 85 organic and volatile organic compounds, pesticides, and wastewater compounds. Of these 85 constituents, 2 compounds were detected above their censoring level, including ABS (table 9) and bis (2-ethylhexyl) phthalate (table 10). There is no State surfacewater-quality standard for ABS. The standard for bis (2-ethylhexyl) phthalate is 59 micrograms per liter $(\mu \mathrm{g} / \mathrm{L})$, which is much higher than the detected concentrations.

Suspended sediment related to fire-related runoff events, recreational use in and near creeks, and runoff from nearby State Highway 4 has been identified as a concern in the Rito de los Frijoles. Analyses of suspended sediment from 194 samples ranged from less than 1 to $98,800 \mathrm{mg} / \mathrm{L}$ in samples collected from the Lower Frijoles between 1977 and 1981 and 1993 and 1995 (table 9). The higher concentrations (greater than 1,100 mg/L) were all measured in 1977 and 1978 and are likely related to La Mesa Fire runoff events. No suspendedsediment concentration data were available for sites in the Upper Frijoles. Elevated suspended-sediment concentrations are generally correlated with high stream discharges and high specific conductance. 
Table 10. Organic compounds and pesticides detected in bed-sediment and fish tissue samples from November 9, 1992, sampling event at site 308, Frijoles Creek below Frijoles Falls, in the Lower Rito de los Frijoles in Bandelier National Monument, New Mexico.

[HHO, human health organism; MCL, Maximum Contaminant Level (U.S. National Drinking Water Standards and Health Criteria); nd, none determined; Ppcode, parameter code; RfD, reference dose; $\mu \mathrm{g} / \mathrm{kg} / \mathrm{day}$, micrograms per kilogram per day; $\mu \mathrm{g} / \mathrm{L}$, micrograms per liter; bold concentrations indicate exceedances of pollution potential or criteria]

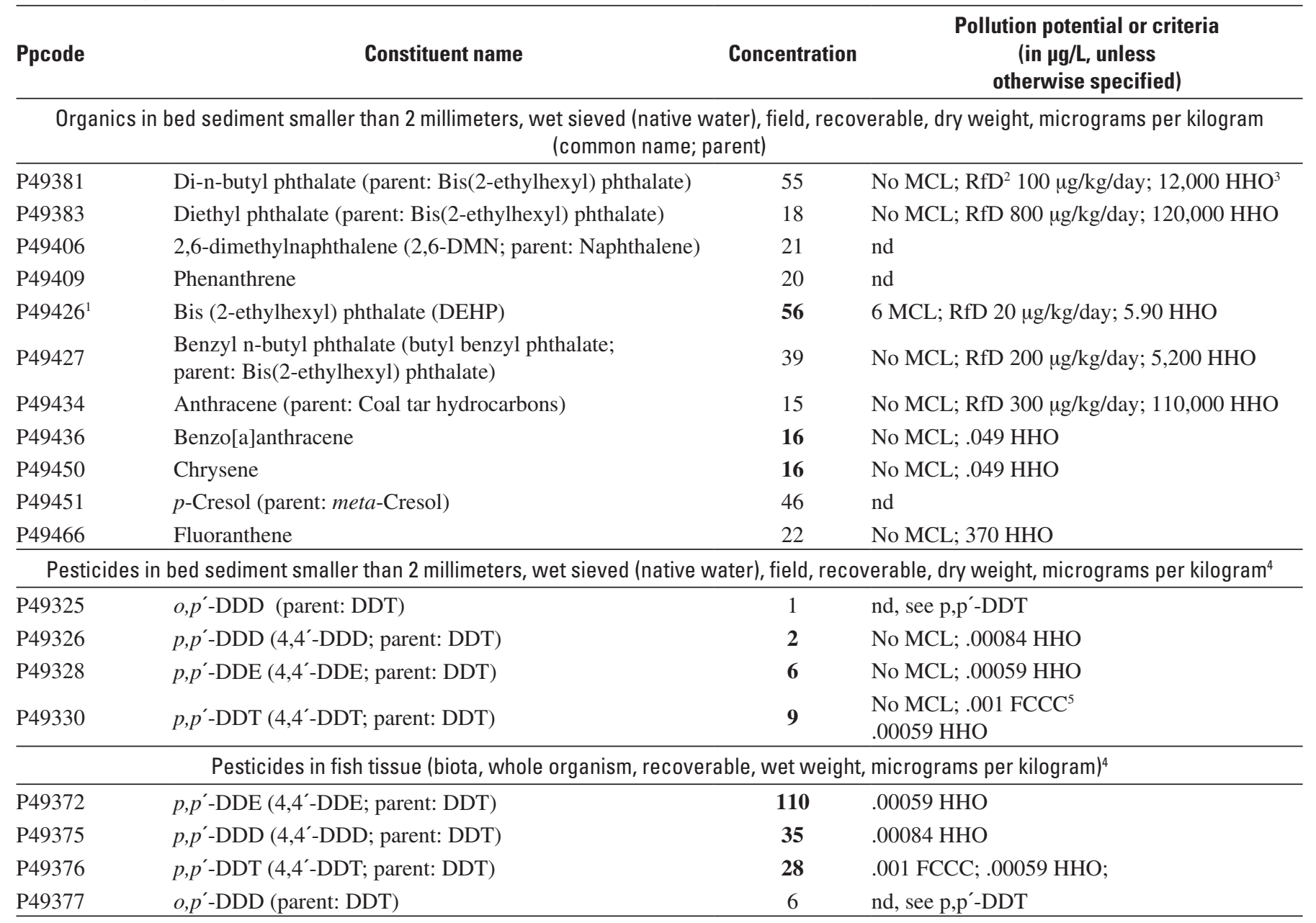

${ }^{1}$ Expected to bioconcentrate in aquatic organisms (U.S. Environmental Protection Agency, 2006b)

${ }^{2}$ The reference dose (RfD) is an estimate of the amount of a given chemical a person can consume each day over a lifetime without incurring "appreciable risk" of negative effects (Pesticide Action Network North America, 2002).

${ }^{3}$ Human health organism (HHO) risk for consumption of an organism with the given concentration based on a probability that the contaminant will cause one new case of cancer in a population of 1,000,000 (Pesticide Action Network North America, 2002).

${ }^{4}$ Total DDT concentrations can be computed by summing the concentrations of $p, p^{\prime}$-DDD, $p, p^{\prime}$-DDE, and $p, p^{\prime}$-DDT.

${ }^{5}$ EPA Freshwater Criterion Continuous Concentration (FCCC) is an estimate of the highest concentration of a pollutant in freshwater to which an aquatic community can be exposed indefinitely (that is, chronic) without resulting in an unacceptable effect (U.S. Environmental Protection Agency, 2006c). 


\section{Trace Elements}

Selected trace-element data are available for sampling sites in Alamo Creek, Capulin Creek, and the Rito de los Frijoles (tables 7, 8, and 9). Very few data are available for Alamo Creek, however, as only two to four samples were collected following the 1977 La Mesa Fire. All Alamo Creek data were collected from site 719 except for three samples for the analysis of uranium, one each of which was collected from sites 719,721 , and 834 . Analyses of samples for unfiltered (or unfiltered recoverable) arsenic, barium, cadmium, copper, lead, mercury, selenium, silver, and filtered hexavalent chromium indicated that concentrations of these metals were all below their respective censoring level. Unfiltered (or unfiltered recoverable) iron (less than 500 to $620 \mu \mathrm{g} / \mathrm{L}$ ), manganese (less than 100 to $100 \mu \mathrm{g} / \mathrm{L}$ ), uranium (2.4 to $3.7 \mu \mathrm{g} / \mathrm{L}$ ), and zinc (less than 500 to $58 \mu \mathrm{g} / \mathrm{L}$ ) were measured at concentrations at or above their respective censoring levels (table 7). No applicable State standards exist for these constituents.

Trace-element data also are very sparse from Capulin Creek; only two to four samples were collected between July 1977 and July 1978 following the 1977 La Mesa Fire. All data were collected from site 5591 except for two samples collected for the analysis of uranium, one each of which was collected from sites 5591 and 310. Analyses of samples for unfiltered (or unfiltered recoverable) arsenic, cadmium, copper, lead, mercury, selenium, silver, and filtered hexavalent chromium indicated that concentrations of these metals were all below their respective censoring level. Unfiltered (or unfiltered recoverable) barium (less than 500 to $780 \mu \mathrm{g} / \mathrm{L}$ ), iron (less than 500 to $3,750 \mu \mathrm{g} / \mathrm{L}$ ), manganese (less than 100 to $1,273 \mu \mathrm{g} / \mathrm{L}$ ), uranium (1.9 to $2.4 \mu \mathrm{g} / \mathrm{L}$ ), and zinc (less than 500 to $62 \mu \mathrm{g} / \mathrm{L}$ ) were measured at concentrations at or above their respective censoring levels (table 8). No applicable State standards exist for these constituents.

Water data for Upper Frijoles Creek are limited to analyses of one sample for a selected suite of unfiltered (or unfiltered recoverable) metals, including arsenic, barium, cadmium, chromium, lead, mercury, selenium, and silver collected June 12, 1985, from site 5576; all results were reported as below their respective censoring levels. Also in Upper Frijoles Creek, four samples for unfiltered uranium from sites 322, 323, 327, and 5576 were collected July 8, 1977, and ranged from 1.9 to $3.4 \mu \mathrm{g} / \mathrm{L}$. In Lower Frijoles Creek, between 3 and 29 samples were collected for various trace elements between 1971 and 1995. The concentrations of chromium (unspeciated and hexavalent), selenium, and silver in these samples were consistently below their censoring level. Maximum observed concentrations of unfiltered (or unfiltered recoverable) barium, iron, lead, and manganese appear to be elevated in some samples; however, no State standards or Federal criteria exist for these constituents (table 9). These elevated values are from 1977 and 1978, following the La Mesa Fire.

For detected trace elements without New Mexico numeric aquatic-life standards or TVS, the concentrations were compared to the chronic NAWQ criteria or Tier II values presented by Suter and Tsao (1996) as toxicological benchmarks useful for screening constituents for aquatic ecological effects. Analyses of samples for filtered iron and manganese were available for Lower Frijoles Creek; all concentrations for these metals were below the respective NAWQ and Tier II criteria (table 9). No filtered trace-element data were available for Alamo or Capulin Creeks.

Most trace-element analyses of water samples from Alamo Creek, Capulin Creek, and the Rito de los Frijoles were made on unfiltered (total or total recoverable) samples. The NMWQCC standards for most metals are typically for filtered constituents; therefore, comparison of the data to State standards was not possible for most metals. Mercury and selenium standards are based on unfiltered concentrations, but all concentrations of these two constituents in all three creeks were below their censoring levels, which were at or greater than the standards.

\section{Water Quality of Springs}

Selected water-quality data from four springs in the monument sampled at the highest frequency and for the longest periods-Apache, Basalt, Frijoles, and Turkey Springs (sites $305,303,556$, and 304, respectively; fig. 2)—are summarized in table 11. Characterization of water quality from sampling sites within the monument is considered relative to specific canyons, probable geologic formation, and land-use factors (for example, monument facilities). Most of the data for Apache, Basalt, and Frijoles Springs (36 out of 37 samples, 38 out of 40 samples, and all 38 samples, respectively) were collected before 1988; therefore, characterization of water quality at these springs is restricted by the historical nature of these data. Within the recent period of record (from 1988 to 1998), 18 of 36 samples were collected from Turkey Spring.

Field properties including ANC, DO (except for Frijoles Spring), pH, SC, turbidity (except for Basalt and Frijoles Springs), and water temperature were measured at all four springs. Samples for analysis of selected organic and radiological constituents (1997 only), nutrients, and trace elements were collected from Basalt Spring in the 1950s and in 1997 and 1998. Apache, Frijoles, and Turkey Springs were each sampled one to six times for analyses of total uranium and nitrate; however, no other samples for the analysis of trace elements or nutrients were collected from these springs. Major ion data were collected from all four springs. Bacteriological data were not collected from any of these springs.

\section{Field Properties}

ANC values ranged between 34.1 and $99 \mathrm{mg} / \mathrm{L} \mathrm{CaCO}_{3}$ and are related to local geology. Generally, ANC measurements were highest at sites 304 (61 to $99 \mathrm{mg} / \mathrm{L}$ ) and 303 (57 to $98 \mathrm{mg} / \mathrm{L}$ ) and lowest at sites 305 (34.1 to $57.5 \mathrm{mg} / \mathrm{L}$ ) and 556 (37.8 to $47.6 \mathrm{mg} / \mathrm{L}$ ).

Dissolved oxygen values ranged from 5.7 to $9.38 \mathrm{mg} / \mathrm{L}$ in Apache, Basalt, and Turkey Springs. From data collected since 
Table 11. Statistical summary of water-quality data and exceedances of water-quality standards in Apache, Basalt, Frijoles, and Turkey Springs in Bandelier National Monument, New Mexico, 1951 to 1998.

$\left[\mathrm{CaCO}_{3}\right.$, calcium carbonate; DMS, domestic water supply; EPA RC, U.S. Environmental Protection Agency National Recommended Nutrient Criteria; fil, filtered; H, high (maximum); HQCF, high quality cold-water fishery; L, low (minimum) standard; mg/L, milligrams per liter; N, nitrogen; NAWQ, National Ambient Water Quality; No., number; NTU, nephelometric turbidity units; P, phosphorus; POR, period of record; rec, recoverable; unfil, unfiltered; $\mu \mathrm{g} / \mathrm{L}$, micrograms per liter; $\mu \mathrm{S} / \mathrm{cm}$, microsiemens per centimeter; <, less than; --, not available; bold type indicates exceedance during recent POR]

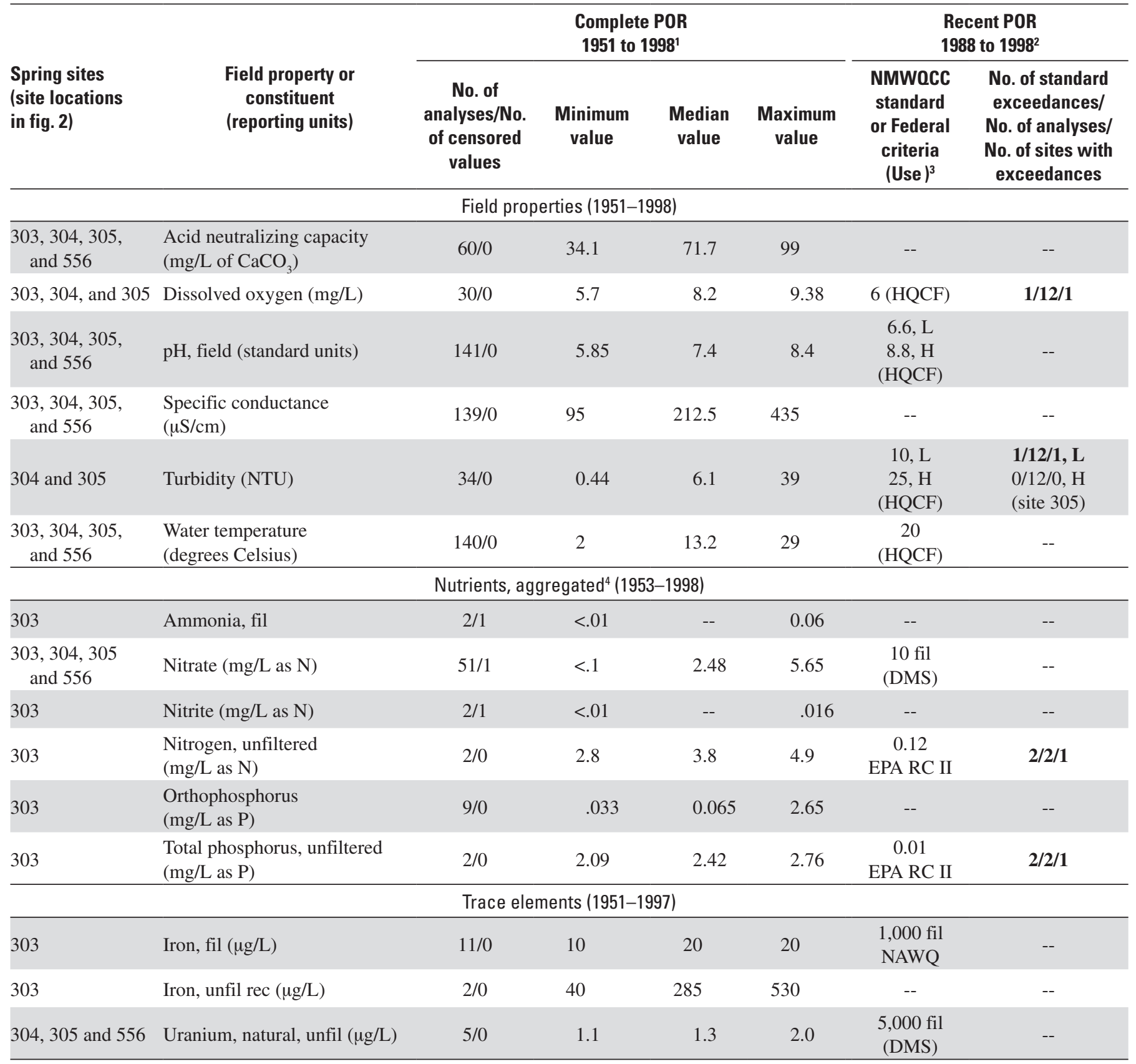

${ }^{1}$ Period of record reflects full range evaluated for all relevant sites within this time period; some sites or constituents may not have had data available for the entire record.

${ }^{2}$ Last 15 years of available data considered for standards exceedance analysis (that is, all samples collected on or after January 1, 1988 through December 31, 2003). At the time of data compilation no data were available from the source databases for the selected sites after 1998.

${ }^{3}$ State standards and designated beneficial uses from the State of New Mexico Water Quality Control Commission (2002). Selected Federal criteria are used when State standards are not established, including the USEPA National Recommended Nutrient Criteria for Ecoregions II and III (U.S. Environmental Protection Agency, 2002), the National Ambient Water Quality criteria (NAWQ), or the secondary chronic Tier II values (Suter and Tsao, 1996).

\footnotetext{
${ }^{4}$ Aggregated nutrients based on Mueller and others (1995); where sample fraction not stated, aggregation includes both filtered and unfiltered concentrations. Zero values were excluded unless converted to a value of less than the censoring level.
} 
1988, one DO measurement from Turkey Spring was below the NMWQCC HQCF minimum standard of $6 \mathrm{mg} / \mathrm{L}$.

No recent (since 1988) $\mathrm{pH}$ values were outside the 6.6 to $8.8 \mathrm{SU}$ range defined by the NMWQCC for a high-quality cold-water fishery (assigned to these springs due to their proximity to the equivalently classified surface waters); however, little to no recent data exist for Apache, Basalt, and Frijoles Springs.

Specific conductance was measured at all four springs and ranged from 95 to $435 \mu \mathrm{S} / \mathrm{cm}$. Most of the SC data for sites 303, 305, and 556 were collected before 1988, though 10 of 28 SC measurements at Turkey Spring were made during the recent period of record. The SC values for Basalt Spring (site 303), though variable, are generally higher than the values for the other springs, while the SC values for Frijoles Spring (site 556) are generally lower than values for the other springs.

Turbidity measurements were available only for Turkey Spring (site 304) and Apache Spring (site 305). Values for site 304 ranged between 0.44 and 7 NTU for 22 samples collected between 1985 and 1992 and were below the NMWQCC 10-NTU low standard for a HQCF. Values from 12 samples collected between 1985 and 1988 from site 305 ranged from 5 to $39 \mathrm{NTU}$; values for 7 samples were equal to or greater than the 10-NTU low standard (only 1 of these collected since 1988). The turbidity of one historical sample, collected in May 1987, from site 305, was measured at 39 NTU and exceeded the State's high turbidity standard of 25 NTU.

Water temperature (along with $\mathrm{pH}$ and $\mathrm{SC}$ ) measurements were made relatively frequently (28 to 40 measurements per spring) at all four springs. Water temperature was highly variable for all four springs and ranged between 2 and $29^{\circ} \mathrm{C}$. The water temperature at site 556 , with a median $19.7^{\circ} \mathrm{C}$ (34 measurements), was generally higher than that at the other three springs, while the water at site 305 had the lowest median temperature, $8.7^{\circ} \mathrm{C}$, based on 35 measurements. No recent data (since 1988) exceeded the NMWQCC HQCF standard of $20^{\circ} \mathrm{C}$; however, five historical measurements, two from site 304 and three from site 556, made in 1984 and 1983, respectively, exceeded this standard (exceedances identified prior to 1988 are not shown on table 11). These differences in temperature may be indicative of the ground-water flow paths and residence times or time of year of sampling.

\section{Major lons}

The volcanic tuff- and basalt-predominated rocks underlying BAND are the principal drivers of major-ion chemistry in Apache, Basalt, Frijoles, and Turkey Springs. Major ion data for Apache, Frijoles, and Turkey Springs are sparse (one to six samples) and were only collected between 1961 and 1978. Between 10 and 39 samples were collected from Basalt Spring (site 303); only one sample collected from this spring in August 1997, during the recent period of record, was analyzed for major ions.
Water types for the four springs ranged from calcium bicarbonate to sodium bicarbonate with varying amounts of other ions (fig. 6). The predominance of bicarbonate is a reflection of the volcanic tuff and (or) basaltic origins of the springs' waters. The water of Frijoles Spring is predominantly sodium bicarbonate, and that of Apache Spring is predominantly bicarbonate with equal relative concentrations of calcium, magnesium, and sodium. Turkey Spring is a calcium bicarbonate water with some chloride, magnesium, and sodium, and Basalt Spring is calcium bicarbonate with some chloride, magnesium, nitrate, sodium, and sulfate. Purtymun and Adams (1980) describe water types for Apache, Frijoles, and Turkey Springs (sites 305, 556, and 304, respectively) and their descriptions generally agree with figure 6 .

Overall, ion concentrations are generally higher in the water of Basalt Spring (site 303) than in the waters of Turkey, Apache, and Frijoles Springs (sites 304, 305, and 556, respectively). Higher ion concentrations at Basalt Spring may be attributable to a longer ground-water residence time and (or) the composition of the underlying formation from which the spring discharges. Purtymun and Adams (1980) suggest that Apache Spring is recharged locally and that the residence time for ground water is about one month. Frijoles Spring, near the mouth of the Rito de los Frijoles, discharges to the Rio Grande. Ground water in the Rio Grande Basin aquifer system near Frijoles Spring (known locally as the main aquifer) is relatively fast moving, with a velocity estimated to be $394 \mathrm{ft}$ per year (Purtymun and Adams, 1980; Robson and Banta, 1995), likely resulting in lower dissolved ion concentrations in this spring due to the short residence time.

\section{Nutrients}

Fifty-one samples from all four springs were analyzed for nitrate (unfiltered and filtered), and concentrations ranged from less than 0.1 to $5.65 \mathrm{mg} / \mathrm{L}$; most of the samples (40) were from Basalt Spring. None of the concentrations exceeded the NMWQCC domestic water-supply standard of $10 \mathrm{mg} / \mathrm{L}$. Measured nitrate concentrations in Apache, Frijoles, and Turkey Springs did not exceed $0.8 \mathrm{mg} / \mathrm{L}$. No other nutrients were analyzed in samples from Apache, Frijoles, and Turkey Springs. In Basalt Spring, samples were analyzed between two and nine times for ammonia (filtered), nitrite (unfiltered and filtered), total nitrogen (unfiltered), orthophosphorus (unfiltered and filtered), and total phosphorus (unfiltered).

No aquatic-life or drinking-water standards exist for total nitrogen in New Mexico; however, the USEPA-recommended criterion for the aggregate nutrient Ecoregion II for total nitrogen in rivers and streams is $0.12 \mathrm{mg} / \mathrm{L}$ (U.S. Environmental Protection Agency, 2002). The two total nitrogen (unfiltered) concentrations measured in Basalt Spring of 2.8 and $4.9 \mathrm{mg} / \mathrm{L}$ both exceed this criterion.

No aquatic-life or drinking-water standards exist for total phosphorus in New Mexico; however, the USEPArecommended criterion for the aggregate nutrient Ecoregion II for total phosphorus in rivers and streams is $0.01 \mathrm{mg} / \mathrm{L}$ 


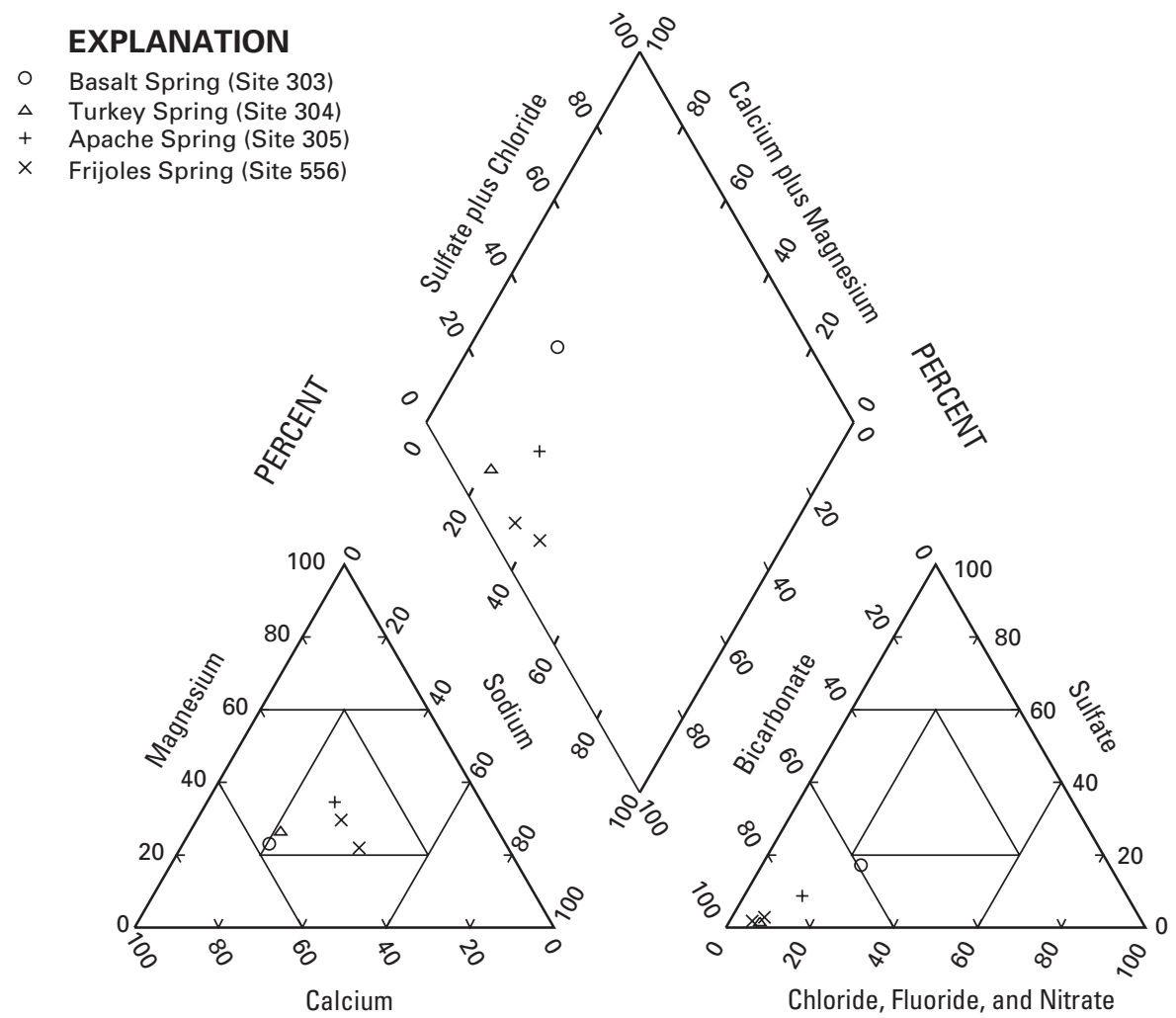

PERCENTAGE OF TOTAL MILLIEQUIVALENTS PER LITER

Figure 6. Water types for Basalt, Turkey, Apache, and Frijoles Springs in Bandelier National Monument, New Mexico, 1965 to 1978.

(U.S. Environmental Protection Agency, 2002). The two total phosphorus (unfiltered) concentrations measured in Basalt Spring in August 1997 and June 1998, 2.09 and $2.76 \mathrm{mg} / \mathrm{L}$, respectively, both exceed this criterion. Elevated phosphorus values may be derived from selected phosphorus-rich minerals, particularly apatite, iron or aluminum phosphates, and plagioclase feldspars that are commonly found associated with basalts and other volcanic rocks (Hem, 1989).

\section{Trace Elements, Radionuclides, and Volatile Organic Compounds}

Filtered and total recoverable iron, the only trace elements analyzed for more than once in samples collected from Basalt Spring, were sampled 11 and 2 times, respectively, between 1951 and 1997. Concentrations of total (recoverable) iron ranged from 40 to $530 \mu \mathrm{g} / \mathrm{L}$, whereas concentrations of filtered iron ranged from 10 to $20 \mu \mathrm{g} / \mathrm{L}$. No standards for iron are established by the NMWQCC, and the iron (unfiltered) concentrations did not exceed the NAWQ criterion of $1,000 \mu \mathrm{g} / \mathrm{L}$.
Total uranium, which can occur naturally, was analyzed in one to three samples from Apache, Frijoles, and Turkey Springs between 1971 and 1977. Concentrations ranged from 1.1 to $2.0 \mu \mathrm{g} / \mathrm{L}$ and were well below the NMWQCC domestic water-supply standard of $5,000 \mu \mathrm{g} / \mathrm{L}$.

On August 14, 1997, USGS collected water samples from Basalt Spring (site 303; fig. 2) for analyses of 23 trace elements, 18 radionuclides, and 13 volatile organic compounds (VOCs). Analyses of these samples indicated that concentrations of 15 of the 23 trace elements and 10 of the 18 radionuclides were above the censoring level (table 12); all other concentrations of trace elements, radionuclides, and VOCs were below censoring levels. None of the detected trace-element concentrations exceeded their respective NMWQCC standard, USEPA maximum contaminant level (MCL), NAWQ criteria, or Tier II values. Values for beta radioactivity and gross beta radioactivity exceeded the MCL of 4 millirems per year $(\mathrm{mrem} / \mathrm{year}$; 1 picocurie per liter $=$ $200 \mathrm{mrem} / \mathrm{yr}$ ). 
Table 12. Summary of trace-element and radionuclide values greater than the censoring level for Basalt Spring from the August 14, 1997, sample in Bandelier National Monument, New Mexico.

[cs, cesium; fil, filtered; ga, gross alpha; MCL, maximum contaminant level (average annual concentrations) from USEPA National Primary or Secondary Drinking Water Regulations; mrem, millirem (to the critical organ); NMWQCC, domestic water-supply standard set by the New Mexico Water Quality Control Commission; Ppcode, parameter code; th, thorium; --, no MCL or NMWQCC standard established; bold type indicates exceedance; 1 picocurie per liter $=200 \mathrm{mrem} / \mathrm{yr}]$

\begin{tabular}{|c|c|c|c|}
\hline Ppcode & Constituent name (reporting units) & $\begin{array}{c}\text { Con- } \\
\text { centration }\end{array}$ & $\begin{array}{c}\text { NMWOCC or Federal } \\
\text { standard }\end{array}$ \\
\hline \multicolumn{4}{|c|}{ Trace elements (micrograms per liter) } \\
\hline P01105 & Aluminum, water, unfiltered, recoverable & 940 & -- \\
\hline P01097 & Antimony, water, unfiltered & 1 & NMWQCC 6 (fil) \\
\hline P01002 & Arsenic, water, unfiltered & 3 & NMWQCC 50 (fil) \\
\hline P71870 & Bromide, water, filtered, milligrams per liter & 0.02 & -- \\
\hline P01037 & Cobalt, water, unfiltered, recoverable & 3.3 & -- \\
\hline P01042 & Copper, water, unfiltered, recoverable & 7.9 & -- \\
\hline P01046 & Iron, water, filtered & 10 & NAWQ (1,000 fil) \\
\hline P01045 & Iron, water, unfiltered, recoverable & 530 & -- \\
\hline P01051 & Lead, water, unfiltered, recoverable & 1 & 50 (fil) \\
\hline P01132 & Lithium, water, unfiltered, recoverable & 20 & -- \\
\hline P01056 & Manganese, water, filtered & 2.8 & Tier II (120 fil) \\
\hline P01055 & Manganese, water, unfiltered, recoverable & 30 & -- \\
\hline P01062 & Molybdenum, water, unfiltered, recoverable & 6 & -- \\
\hline P01067 & Nickel, water, unfiltered & 7.6 & NMWQCC 100 (fil) \\
\hline P01082 & Strontium, water, unfiltered & 90 & -- \\
\hline \multicolumn{4}{|c|}{ Radionuclides (all units in picocuries per liter unless otherwise stated) } \\
\hline P75987 & Alpha radioactivity 2-sigma combined uncertainty, water, filtered, th-230 curve & 1.7 & NMWQCC 15 (ga) \\
\hline P75989 & Beta radioactivity 2-sigma combined uncertainty, water, filtered, cs-137 curve & 4.1 & MCL (4 mrem/yr) \\
\hline P03515 & Gross beta radioactivity, water, filtered, cs-137 curve & 8.8 & MCL (4 mrem/yr) \\
\hline P49939 & Plutonium-238 2-sigma combined uncertainty, water, filtered & 0.01 & -- \\
\hline P76003 & Strontium-90 2-sigma combined uncertainty, water, filtered & 26 & NMWQCC 8 \\
\hline P75985 & Tritium 2-sigma combined uncertainty, water, unfiltered & 26 & NMWQCC 20,000 \\
\hline P07000 & Tritium, water, unfiltered & 60 & NMWQCC 20,000 \\
\hline P75992 & Uranium-234 2-sigma combined uncertainty, water, filtered & .03 & -- \\
\hline P75994 & Uranium-235 2-sigma combined uncertainty, water, filtered & .01 & -- \\
\hline P75991 & Uranium-238 2-sigma combined uncertainty, water, filtered & .03 & -- \\
\hline
\end{tabular}




\section{Summary of Surface-Water and Springs Characterization and Considerations for Monitoring}

For the surface water in BAND, bacteriological contamination from back-country recreational use was identified as a water-quality concern in Alamo and Capulin Creeks and the Rito de los Frijoles. Fecal coliform counts exceeded State standards twice each in Capulin Creek and the Rito de los Frijoles. However, coliform sampling was infrequent, so it is not possible to identify whether these exceedances were isolated occurrences of elevated coliform counts or whether exceedances are a regular occurrence associated with increased visitor numbers or other potential factors. Regular bacteriological sampling would be helpful to identify if coliform exceedances are a chronic occurrence. If sampling indicates a recurring problem, a bacteriological source tracking study could be done to determine if the coliform were of human or animal origin.

Fire-related effects have resulted in altered, degraded water quality in Alamo Creek, Capulin Creek, and the Rito de los Frijoles, which is evidence that postfire runoff control efforts are an important management step that BAND can take when fires occur in the canyons and headwater forests. A plan for monitoring water quality in the monument's creeks following large fires would be useful in identifying key water-quality concerns related to postfire runoff and in monitoring stream recovery; however, a long-term water-quality monitoring plan that incorporates suspended sediment, major ions, nutrients, and trace-element monitoring would be required to compare fire-related effects to baseline water-quality conditions.

Concerns regarding elevated levels of turbidity may be warranted; however, the cause of these elevated values is not clearly established, and natural runoff events may well be a factor in elevated turbidity. Recent (September 2001) sampling did not indicate elevated turbidity levels. No turbidity measurements were available following the 1996 Dome Fire, when fire-related runoff would have been expected to result in increased sediment loads in Capulin Creek.

The few trace-element data do not conform to State requirements for filtered fraction samples (for most constituents); therefore, determination of compliance with State standards is not possible. Censoring levels commonly match or exceed standard levels, which limits the ability to relate traceelement concentrations to regulatory criteria. Trace-element data for Alamo and Capulin Creeks are limited to one to four samples collected in 1977 and 1978 following the La Mesa Fire. Trace-element data for the Rito de los Frijoles is available only through 1995. Current trace-element data analyzed at applicable censoring levels will be required to define and characterize the water-quality conditions in Alamo Creek, Capulin Creek, and the Rito de los Frijoles.

Effects of runoff from State Highway 4 are not evident in the historical water-quality data for the Rito de los Frijoles; however, this may be due to the sampling frequency and timing in relation to potential contributing runoff events. A focused effort would be needed to determine if this concern is a management priority for protecting water quality in the Rito de los Frijoles.

Water-quality data are sparse for Apache, Basalt, Frijoles, and Turkey Springs in BAND. Most of the available data were collected before 1979 . The only spring with recent data is Basalt Spring. The volcanic tuff and (or) basalt underlying most of the monument are the principal drivers controlling the bicarbonate and calcium bicarbonate waters discharging from these springs. Elevated concentrations of nitrogen and phosphorus may be a consequence of local runoff, atmospheric deposition, trespass grazing near springs, or from transport through the aquifer from affected recharge areas outside the park. Elevated phosphorus concentrations at Basalt Spring also may be derived from apatite and related volcanic minerals associated with the underlying basalt. If some or all of these springs are determined by the SCPN and BAND to be a high priority, then regular water-quality sampling, including nutrients, will be needed to establish a current water-quality baseline.

\section{Canyon de Chelly National Monument, Arizona}

Canyon de Chelly National Monument (CACH) is in the high plateau area of the Navajo Nation Reservation in northeastern Arizona. The monument is characterized by a distinct, amorphous, two-fingered canyon (Canyon del Muerto and Canyon de Chelly) carved by erosion from wind and by streams that flow westward from their origins on the northwest slope of the Defiance Plateau (fig. 7). $\mathrm{CACH}$, which encompasses 83,840 acres $\left(130 \mathrm{mi}^{2}\right)$, ranges in elevation from 5,500 to $7,500 \mathrm{ft}$. The monument is bordered on the east by the Chuska Mountains, which trend north-northwest along the Arizona-New Mexico border. The mountains end at Chinle Wash, where the exposed De Chelly Sandstone disappears underground east of Chinle, Arizona (National Park Service, 2005a). The monument was established in 1931 for its extensive archeological remains and is jointly administered by the NPS, which manages the cultural and natural resources and monument visitor services, and the Navajo Nation, which retains control of the surface and subsurface (that is, mineral) uses of the land within the monument. CACH lies entirely within the boundary of the Navajo Indian Reservation, and the canyon floors provide the land for homes, farms, and grazing for approximately 50 Navajo families (Eckert and others, 2003). Agriculture, including alfalfa, squash, corn, and fruit orchards and intensive grazing by sheep, cattle, horses, and goats, has been ongoing for many years in the canyon drainages. A majority of the current activities occur in Canyon del Muerto and in the Tsaile Creek drainage upstream from the monument (Natural Resources Conservation Service, 1999).

$\mathrm{CACH}$ has an arid climate characterized by periods of drought (National Park Service, 2005a). Climate station 021248 is in $\mathrm{CACH}$ at an elevation of 5,610 ft in Monument 
Canyon (fig. 7). Mean annual precipitation is about 9.2 inches (1970-2006) with August the wettest month (1.3 inches) and June the driest (0.3 inch) (Western Regional Climate Center, 2006). July through October comprise the monsoonal season in the monument. Average annual snowfall is 5.7 inches with most snowfall occurring in January (1.8 inches). Average monthly air temperatures ranged from $18.8^{\circ} \mathrm{F}$ in December to $92.4^{\circ} \mathrm{F}$ in July with an average annual temperature of $53.5^{\circ} \mathrm{F}$ and with daily extremes ranging from $-24^{\circ} \mathrm{F}$ on January 3 , 1974 , to $105^{\circ} \mathrm{F}$ on July 2, 2002 (Western Regional Climate Center, 2006). Summer thunderstorms have been estimated to contribute approximately 40 percent of the rainfall in a typical year (Natural Resources Conservation Service, 1999). In the headwaters of the monument in the Chuska Mountains, precipitation in the form of rain and snow is greater than in the canyons. Average annual precipitation in the headwaters area is estimated to be approximately 18 inches total with about 7 to 8 inches from snowfall (Harshbarger and Repenning, 1954).

\section{Geology}

The Organ Rock Formation of the Cutler Group (Early Permian Period) is exposed in some areas of the monument and underlies the predominant De Chelly Sandstone (Baars, 2000; Nations and Stump, 1981). During the middle Permian Period (around 260 million years ago), the distinctive, steeply inclined, crossbedded, wedge-shaped De Chelly Sandstone, which forms the monument's walls, was deposited as windblown dune sands (Baars, 2000). Capping the De Chelly Sandstone in the area of the monument is the Triassic Shinarump Conglomerate, the basal member of the Chinle Formation. Alluvium (unconsolidated sediments) composed mostly of sand is present in the drainage bottoms of CACH (Thomas and others, 2006). The headwaters of the monument's canyons, which begin in the Chuska Mountains, issue from the base of the Chuska Sandstone (Tertiary Period) and the Chinle Formation (Triassic Period). Scattered igneous rocks (plugs, dikes, and lava flows) occur in the Chuska Mountains, resulting in breccia and tuff deposits from which small springs discharge; though these springs are smaller (lower discharge) than those issuing from sandstones, they could contribute to the water-quality signature in selected headwater canyon streams (Harshbarger and Repenning, 1954).

The Organ Rock Formation, principally a red siltstone and shale, is hydrogeologically important because many of the springs discharging within $\mathrm{CACH}$ originate at the Organ Rock-De Chelly contact (Baars, 2000; Stephen Monroe, National Park Service, written commun., 2007). The overlying De Chelly Sandstone is a reddish-orange, well-sorted, fine- to very fine-grained sandstone with some cementation, making it a relatively good aquifer. Locally, the Chinle Formation contains claystone, mudstone, and siltstone, which erode easily, resulting in sediment that is accumulating in Tsaile Lake (Natural Resources Conservation Service, 1999). The Shinarump Conglomerate is a yellowish-gray stratum composed of poorly sorted, moderate- to well-cemented sandstones intermixed with lenses of consolidated gravel and is known for its petrified conifer logs and associated deposits of uranium (Harshbarger and Repenning, 1954; Nations and Stump, 1981). The Chuska Sandstone is a white to gray, medium to fine-grained, moderately sorted sandstone and is the principal aquifer providing base flow to headwater tributaries.

\section{Water Resources}

The monument includes two main canyons (Canyon del Muerto and Canyon de Chelly) and two smaller canyons (Black Rock Canyon and Monument Canyon) along with multiple side canyons and arroyos. The streamflow in these canyons and arroyos is supported by occasional flooding from summer thunderstorms and spring snowmelt-derived runoff (National Park Service, 2005a). Springs that discharge from cliff faces at geologic contacts support intermittent flow within the monument canyons and form unique microenvironments (hanging gardens) of high biodiversity. The main canyons trend westward from the eastern edge of the Defiance Plateau to Chinle Wash located about 10 mi west of the Chuska Mountains (fig. 7). The canyons have steep, vertical walls that range from $30 \mathrm{ft}$ near the mouth of Canyon de Chelly to $1,000 \mathrm{ft}$ deep with an average depth of $700 \mathrm{ft}$ (www2.nature.nps.gov/ geology/parks/cach/index.cfm, accessed February 10, 2006).

Tsaile Creek perennially feeds Canyon del Muerto, and Wheatfields and Whiskey Creeks (which are perennial in the upper reaches) are the principal streams flowing into Canyon de Chelly. All of these drainages originate above 8,000 ft in the Chuska Mountains, an upland area that contains more perennial streams than any other part of the Navajo Nation lands due to relatively high amounts of precipitation (Eckert and others, 2003; Harshbarger and Repenning, 1954). Streams become intermittent or ephemeral in and near the monument. Tsaile Creek is the only perennial stream between the Chuska Mountains and the monument. Riparian areas along the perennial reaches of these streams are especially important for the flora and fauna that inhabit the area, including migratory birds (Thomas and others, 2006). The headwater streams become intermittent as they leave the Defiance Plateau and enter the monument due to evapotranspiration, losses to alluvium and bedrock aquifers, and diversions for agricultural use. Harshbarger and Repenning (1954) identified the point of minimum flow on all streams in the area where the streams enter the canyons of $\mathrm{CACH}$; downstream from this point, streamflow increases due to spring snowmelt runoff, occasional monsoonal rainstorms, and springs discharging along canyon walls. Canyon de Chelly ultimately drains into the San Juan River Basin by way of Chinle Wash.

Streams are incised into the sediments within the canyons and continue to downcut, affecting irrigation diversions, lowering the water table, and favoring the survival and spread of invasive flora species such as tamarisk and Russian olive over native species such as cottonwood and willow. In 2005 the NPS initiated an extensive effort to eradicate these species 

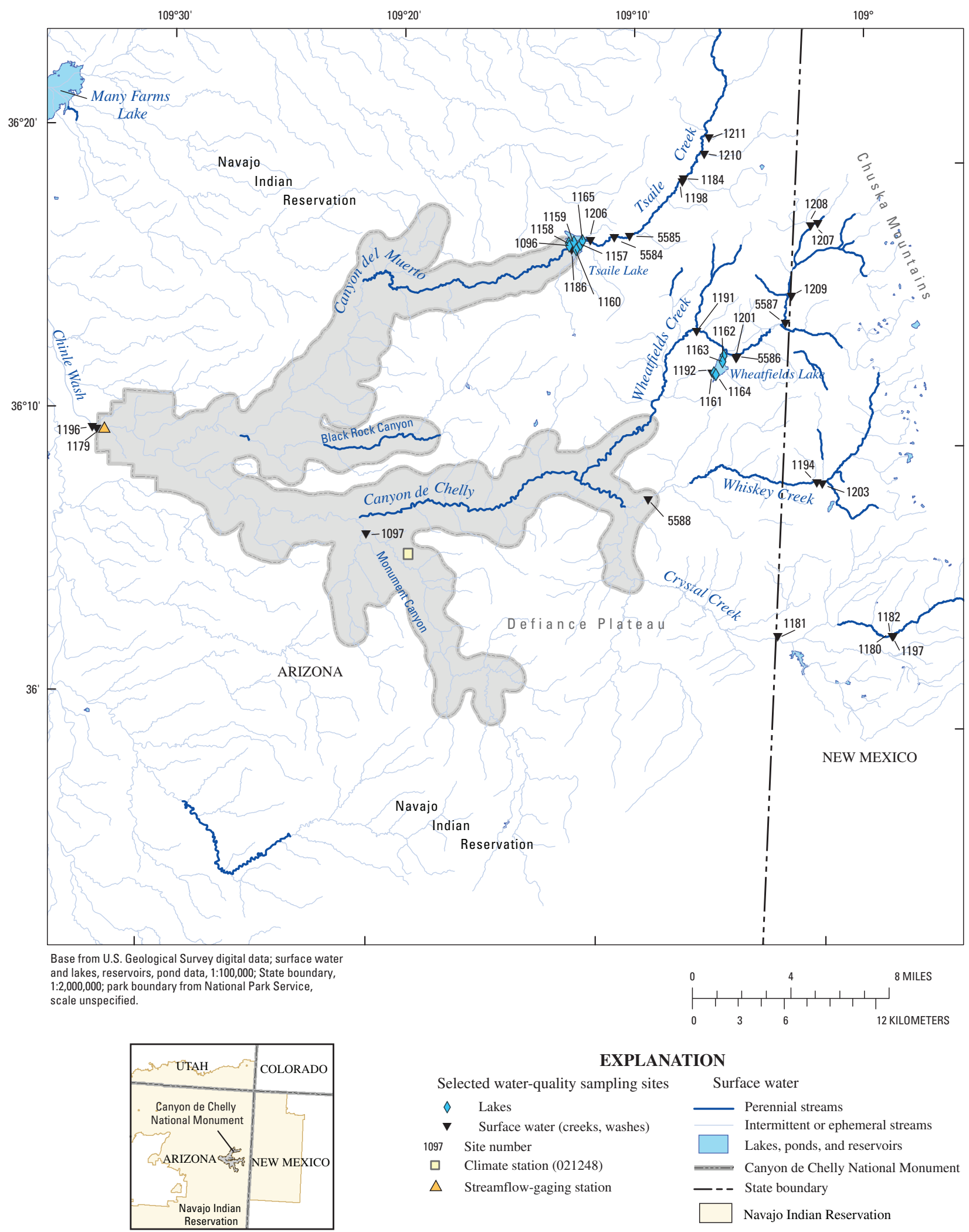

EXPLANATION

Selected water-quality sampling sites Surface water

$\diamond \quad$ Lakes

- Perennial streams

Surface water (creeks, washes)

1097 Site number

ㅁ Climate station (021248)

$\triangle$ Streamflow-gaging station

Intermittent or ephemeral streams

Lakes, ponds, and reservoirs

--.-- Canyon de Chelly National Monument

- - State boundary

Location map

Figure 7. Canyon de Chelly National Monument, Arizona, and locations of water-quality sampling sites. 
from along the riparian corridor in $\mathrm{CACH}$ (National Park Service, 2005a). Subsistence agriculture and grazing occur in the canyon bottoms and rely on the limited water in $\mathrm{CACH}$. Currently (2007) the monument gets its water supply for visitors and employees from a 600-ft supply well at the Visitor's Center that likely draws water from the De Chelly Sandstone aquifer (National Park Service, 2005b; Thomas and others, 2006; Donald Bills, U.S. Geological Survey, written commun., 2006). The sandstone formations (De Chelly Sandstone, Shinarump Conglomerate, and Chuska Sandstone) are the most likely aquifers for additional development along with the alluvial deposits in the stream channels.

Two large earthen storage reservoirs (Tsaile and Wheatfields Lakes) were constructed on the upper canyon rims primarily for recreational and agricultural purposes (fig. 7). Wheatfields Lake, which is adjacent to Wheatfields Creek, was constructed in 1963 and has a storage capacity of 5,700 acre-ft (Natural Resources Conservation Service, 1999). This reservoir is filled by diverted flow from Wheatfields Creek, which accounts for as much as 6 percent of the runoff from the Canyon de Chelly drainage (Eckert and others, 2003). Tsaile Lake is located directly on Tsaile Creek and was constructed in 1964; it has a storage capacity of 3,100 acre-ft and can discharge as much as $52 \mathrm{ft}^{3} / \mathrm{s}$ (Eckert and others, 2003; Natural Resources Conservation Service, 1999). These dams have reduced peak flows during snowmelt, limited the availability of fine-grained sediment (and thus increased the erosive potential of the flows), enabled encroachment of exotic vegetation along stream channels, and resulted in a longer, smaller sustained spring runoff period. The altered runoff period has had a negative effect on the Navajo farmers' ability to access and plant their crops in the upper parts of the canyon (Natural Resources Conservation Service, 1999; National Park Service, 2005b). Eckert and others (2003) determined that the direct effect of Wheatfields Lake on reducing the natural peak flows of Canyon de Chelly was minor and that in larger runoff years the effect from Tsaile Lake also would be minor due to the emergency spillway that flows back into Tsaile Creek when the reservoir is at capacity.

Since December 1999, a streamflow-gaging station (USGS Station 09379025) has been operated near the boundary of $\mathrm{CACH}$ and site 1179 (fig. 7). Mean monthly streamflow ranges from $49.2 \mathrm{ft}^{3} / \mathrm{s}$ in April to $0.14 \mathrm{ft}^{3} / \mathrm{s}$ in November. The highest annual streamflow was recorded in water year $2004\left(14.7 \mathrm{ft}^{3} / \mathrm{s}\right)$ and the lowest was in water year $2002\left(1.25 \mathrm{ft}^{3} / \mathrm{s}\right)$. The highest peak flow was recorded on August 13, 2001, at 1,000 $\mathrm{ft}^{3} / \mathrm{s}$, which was the most recent year continuous streamflow data were available for this station (U.S. Geological Survey, 2001). Typical annual hydrographs for the western drainages flowing from the Defiance Plateau region show snowmelt-driven runoff peaks in midspring; occasional flash-flood responses can result in a secondary peak from summer monsoons. Typical hydrographs also indicate extended periods of very low to no flow.

Navajos have used the Canyon de Chelly area for agriculture since A.D. 1700, which has contributed to the current state of range deterioration and poor condition of the riparian areas upstream from and within the monument. The 1996 Navajo Nation Watershed Prioritization Study ranked Canyon de Chelly watershed as the number one priority out of 18 locally identified watersheds for watershed restoration planning and project development (Natural Resources Conservation Service, 1999).

There are multiple, potential sources of impairment in these canyons. Encroachment of exotic vegetation can threaten plant communities and cultural resources and lower the water table. Diversion structures in the canyon's headwaters that are used to support agriculture reduce the amount of water reaching downstream riparian habitats. Recreational and residential vehicles result in erosion and pollution. Residential and commercial development and mining in the headwaters and near canyon rims can degrade water quality, while agriculture and ranching activities in and upstream from the monument can lead to erosion and elevated nutrient concentrations in streams. Depletion of the ground-water supply, apparent die-off or decline of hanging gardens, and a general lack of coordinated management between the NPS and Navajo Nation regarding the monument's water resources also are contributing to the impairment of CACH water resources (Thomas and others, 2006; Natural Resources Conservation Service, 1999). Despite the numerous water-quality and quantity concerns, the monument's watershed is an important natural and cultural resource to the canyon residents and monument visitors.

\section{Available Water-Quality Data}

Water-quality data from 225 samples were evaluated for this report, which include data for: (1) water flowing into the monument from headwater creeks, including samples from Tsaile, Wheatfields, Whiskey, and Crystal Creeks and Monument Canyon (includes three sites within the park); (2) samples from Tsaile and Wheatfields Lakes upstream from the monument; and (3) samples from Chinle Wash flowing out of the park (fig. 7; table 13). The relative temporal distribution of water samples from sites with available data and the types of analyses conducted on samples are illustrated in figure 8 . The number of analyses by constituent or field property is provided in table 14. The NNEPA collected 77 percent of these samples, the NPS 21 percent, and the USGS 2 percent. For the headwater creeks, there was one sample collected in 1978 from a site in Monument Canyon and 154 samples (from 24 sites in Tsaile, Wheatfields, Whiskey, and Crystal Creeks) collected between 1978 and 2003 by the NNEPA and NPS. Only 10 creek samples (from three sites) were collected within the boundary of $\mathrm{CACH}$; the remaining 144 samples were collected upstream from the monument. From Tsaile and Wheatfields Lakes, there were 66 samples (from 10 sites) collected between 1967 and 2003 by the NNEPA and USGS; 62 of the samples were collected since 1996. In March 1971 the USGS collected one sample from Chinle Wash near the monument boundary. The NNEPA collected three samples (from one site) inside the monument boundary between 1999 and 2003. 
Table 13. Stream and lake sites with water-quality data in, near, or upstream from Canyon de Chelly National Monument, Arizona, 1967 to 2003.

[DD, decimal degrees; m, meters; No., number; NTUA, Navajo Tribal Utility Authority; nr, near; Trib., tributary; Site no. shown in figure 7; *, sites located within the monument boundary; site names retained from original source database]

\begin{tabular}{|c|c|c|c|c|c|}
\hline $\begin{array}{l}\text { Site } \\
\text { no. }\end{array}$ & Site name & $\begin{array}{c}\text { Latitude } \\
\text { DD }\end{array}$ & $\begin{array}{c}\text { Longitude } \\
\text { DD }\end{array}$ & $\begin{array}{c}\text { No. of } \\
\text { samples }\end{array}$ & $\begin{array}{c}\text { Period of } \\
\text { record }\end{array}$ \\
\hline \multicolumn{6}{|c|}{ Headwater creeks } \\
\hline \multicolumn{6}{|c|}{ Crystal Creek sites } \\
\hline 1180 & Crystal Creek & 36.0536 & 108.9610 & 18 & $1995-2003$ \\
\hline 1181 & Crystal Creek & 36.0493 & 109.0444 & 1 & 2000 \\
\hline 1182 & Crystal Creek & 36.0536 & 108.9610 & 3 & 1997-2003 \\
\hline 1197 & Upstream of Bridge near Crystal NM & 36.0536 & 108.9604 & 7 & 1995-1998 \\
\hline \multicolumn{6}{|c|}{ Monument Canyon site } \\
\hline $1097 *$ & N00946 & 36.1000 & 109.3464 & 1 & 1978 \\
\hline \multicolumn{6}{|c|}{ Tsaile Creek sites } \\
\hline 1184 & Tsaile Creek & 36.3175 & 109.1271 & 10 & 1996-1999 \\
\hline $1186 *$ & Tsaile Creek & 36.2739 & 109.2050 & 1 & 2000 \\
\hline 1198 & Tsaile Creek at Forest Road Junction & 36.3160 & 109.1280 & 6 & 1996-1998 \\
\hline 1206 & N01248 & 36.2792 & 109.1928 & 1 & 1978 \\
\hline 1210 & N01266 & 36.3319 & 109.1128 & 1 & 1978 \\
\hline 1211 & N01267 & 36.3414 & 109.1100 & 1 & 1978 \\
\hline 5584 & Tsaile Creek 50 m below N12 Bridge & 36.2812 & 109.1758 & 24 & 1996-2003 \\
\hline 5585 & Tsaile Creek Trib 0.25 Mile upstream from Lake & 36.2826 & 109.1645 & 6 & 1995 \\
\hline \multicolumn{6}{|c|}{ Wheatfields Creek sites } \\
\hline 1191 & Wheatfields Creek & 36.2290 & 109.1124 & 1 & 2000 \\
\hline 1192 & Wheatfields Creek & 36.2050 & 109.1003 & 1 & 2000 \\
\hline 1201 & Wheatfields Creek Gaging Station & 36.2138 & 109.0821 & 6 & 1995-1998 \\
\hline 1207 & N01261 & 36.2942 & 109.0281 & 1 & 1978 \\
\hline 1208 & N01262 & 36.2942 & 109.0333 & 1 & 1978 \\
\hline 1209 & N01263 & 36.2514 & 109.0433 & 1 & 1978 \\
\hline 5586 & Wheatfields Creek, 40 m upstream Wheatfields Lake Diversion & 36.2143 & 109.0819 & 15 & 1995-1998 \\
\hline 5587 & Wheatfields Creek, $100 \mathrm{~m}$ downstream of gage & 36.2372 & 109.0481 & 17 & 1995-2003 \\
\hline \multicolumn{6}{|c|}{ Whiskey Creek sites } \\
\hline 1194 & Whiskey Creek & 36.1424 & 109.0187 & 17 & 1995-2003 \\
\hline 1203 & Upper Whiskey Creek Gaging Station & 36.1421 & 109.0171 & 7 & 1995-1998 \\
\hline $5588 *$ & Whiskey Creek $20 \mathrm{~m}$ upstream Gaging Station & 36.1279 & 109.1417 & 8 & $1995-2000$ \\
\hline \multicolumn{6}{|c|}{ Headwater lakes } \\
\hline \multicolumn{6}{|c|}{ Tsaile Lake sites } \\
\hline $1096 *$ & Tsaile Lake Surface Sample & 36.2750 & 109.2076 & 2 & $1987-1988$ \\
\hline 1157 & Tsaile Lake East Shore - Fecal & 36.2760 & 109.1982 & 2 & 2001-2002 \\
\hline $1158 *$ & Tsaile Lake West Shore - Fecal & 36.2763 & 109.2077 & 2 & 2001-2002 \\
\hline 1159 & Tsaile Lake - Wq_N & 36.2774 & 109.2043 & 15 & 2001-2003 \\
\hline $1160 *$ & Tsaile Lake - Wq_S & 36.2728 & 109.2024 & 15 & 2001-2003 \\
\hline 1165 & Tsaile Lake 1105111001527 & 36.2783 & 109.1979 & 2 & $1967-1970$ \\
\hline \multicolumn{6}{|c|}{ Wheatfields Lake sites } \\
\hline 1161 & Wheatfields Lake - Fecal & 36.2038 & 109.0983 & 4 & $1997-2002$ \\
\hline 1162 & Wheatfields Lake - Fecal & 36.2138 & 109.0919 & 2 & 2001-2002 \\
\hline 1163 & Wheatfields Lake - Wq_N & 36.2106 & 109.0924 & 11 & 2001-2003 \\
\hline 1164 & Wheatfields Lake - Wq_S & 36.2028 & 109.0968 & 11 & 2001-2003 \\
\hline \multicolumn{6}{|c|}{ Chinle Wash sites } \\
\hline $1179 *$ & Chinle Wash & 36.1548 & 109.5385 & 3 & 1999-2003 \\
\hline 1196 & Chinle Creek nr NTUA South Well & 36.1544 & 109.5457 & 1 & 1971 \\
\hline
\end{tabular}




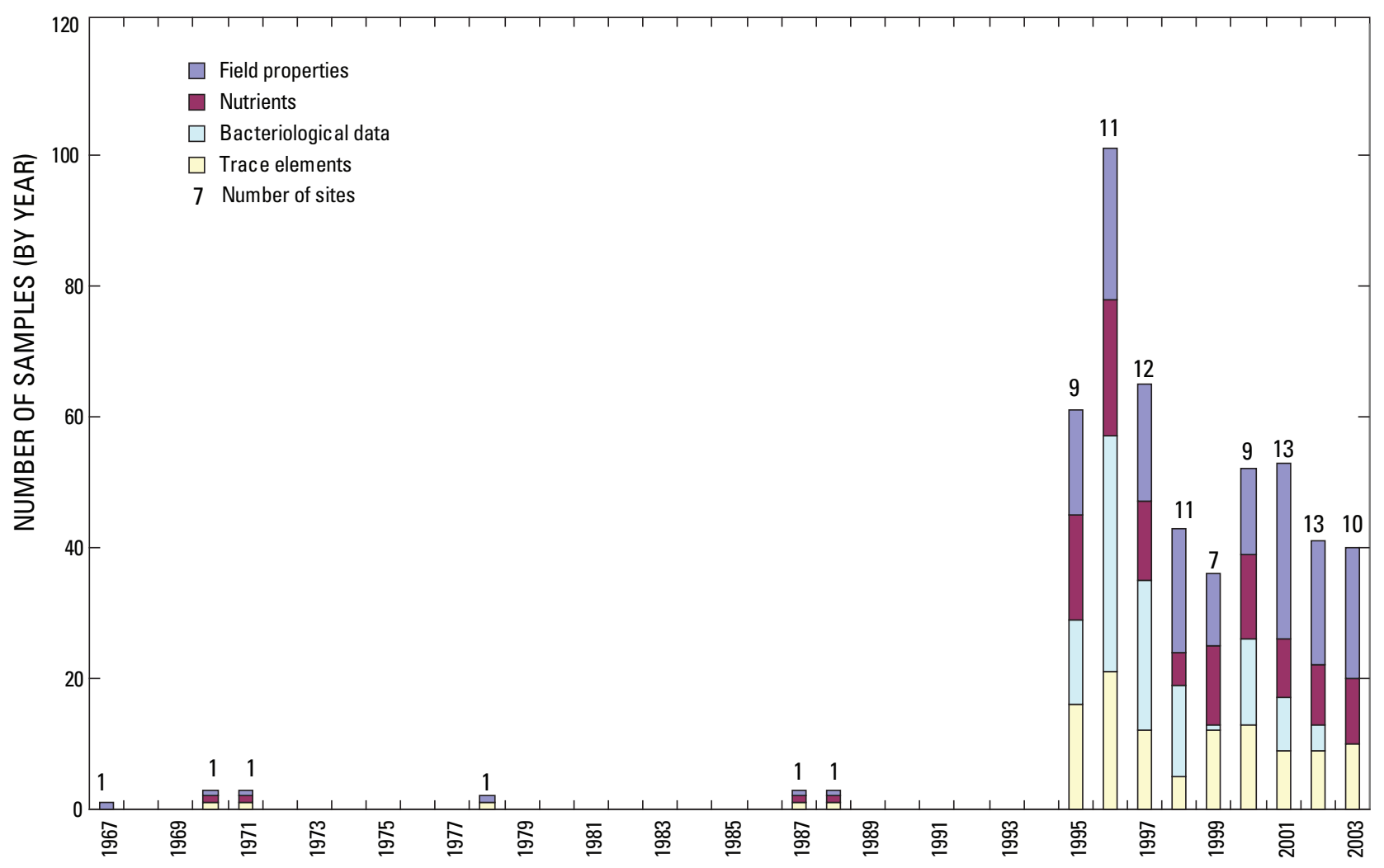

Figure 8. Total number of stream and reservoir samples collected for bacteriological data, trace elements, nutrients, and field properties, number of sites, and period of record, Canyon de Chelly National Monument, Arizona, 1967 to 2003.

Few water-quality data were collected prior to 1995 , and few of the data were collected inside the monument boundary. Only four sites (sites 1180, 1194, 5584, and 5587, fig. 7; table 13) had more than 15 samples collected over the period of record. Monument Canyon has only one historical sample collected in 1978 and very little data (four samples) were collected for Chinle Wash, limiting potential interpretation of these waters.

\section{Characterization of Water Quality}

Selected available water-quality data from headwater creeks, Tsaile and Wheatfields Lakes, and Chinle Wash are summarized in table 14 . Water-quality categories evaluated include field properties, nutrients, bacteriological data, other constituents (chlorine, suspended solids, and dissolved solids), and trace elements.

Surface water in the monument has not been assessed and classified as part of Arizona's 303(d) process, and Tribal Water Quality Standards have not been approved by the USEPA for this area; therefore, all CACH sites were evaluated under the Arizona "tributary rule" for comparison to numeric standards. This rule (Arizona Administrative Code R18-11-105, amended 2002) is used by the State to determine designated uses for waters not specifically listed in the surface-water protection rules. For the water-quality standard exceedance analysis conducted for this report (table 14), all sites evaluated at $\mathrm{CACH}$ within the State boundary were considered intermittent or perennial and above 5,000 ft and, therefore, were designated for aquatic and wildlife cold-water use. Stream sites in New Mexico (far upstream from the monument boundary) were not evaluated for water-quality standard exceedances.

\section{Field Properties}

Acid neutralizing capacity, $\mathrm{DO}, \mathrm{pH}, \mathrm{SC}$, turbidity, and water temperature were measured between 76 and 115 times at 18 headwater creek sites. Tsaile and Wheatfields Lakes had field properties measured between 2 and 47 times at eight sites, with multiple depths measured during a single day's sampling event. Chinle Wash had selected field properties measured only three or four times at two sites. Streamflow was measured 35 times at 10 sites in the headwater creeks but was measured only twice in Chinle Wash. Dissolved oxygen, $\mathrm{pH}$, and turbidity values exceeded the Arizona aquatic cold-water fishery standards in one or all of these waters between 1988 and 2003 (table 14).

Exceedances for low DO, below the aquatic cold-water 7-mg/L standard, were observed in measurements made from all three water groups. Nearly one-half of all Tsaile and Wheatfields Creek measurements (29 of 60 values), 
Table 14. Statistical summary of water-quality data and exceedances of water-quality standards in selected surface-water sampling sites located in, near, and upstream from Canyon de Chelly National Monument, Arizona, 1967 to 2003.

[AWC, aquatic cold water; AZDEQ, Arizona Department of Environmental Quality; col/100 mL, colonies per 100 milliliters; Cr III, chromium III; deg C, degrees Celsius; DWP, drinking-water protected use; EPA RC III, U.S. Environmental Protection Agency National Recommended Nutrient Criteria for Ecoregion III; FBC, full-body contact; FC, fish consumption; fil, filtered; $\mathrm{ft}^{3} / \mathrm{s}$, cubic feet per second; GM, geometric mean; $\mathrm{H}$, high (maximum) standard; I, instantaneous; L, low (minimum) standard; mg/L, milligrams per liter; MPN, most probable number; N, nitrogen; No., number; NTU, nephelometric turbidity units; P, phosphorus; $\mathrm{pCi} / \mathrm{L}$, picocuries per liter; POR, period of record; rec, recoverable; SS, suspended sediment concentrations (at or near baseflow only); SU, standard units; TVS, table value standard; unfil, unfiltered; unsp, unspeciated; $\mu \mathrm{S} / \mathrm{cm}$, microsiemens per centimeter; <, less than; >, greater than; --, not available or not computed; bold type indicates exceedance during recent POR]

\begin{tabular}{|c|c|c|c|c|c|c|c|}
\hline \multirow[b]{2}{*}{$\begin{array}{l}\text { Selected } \\
\text { surface-water } \\
\text { sites (see figure } 7 \\
\text { for location } \\
\text { of sites) }\end{array}$} & \multirow[b]{2}{*}{$\begin{array}{l}\text { Field property } \\
\text { or constituent } \\
\text { (reporting units) }\end{array}$} & \multicolumn{4}{|c|}{$\begin{array}{c}\text { Complete POR } \\
1967 \text { to } 2003^{1}\end{array}$} & \multicolumn{2}{|c|}{$\begin{array}{l}\text { Recent POR } \\
1988 \text { to } 2003^{2} \\
\end{array}$} \\
\hline & & $\begin{array}{l}\text { No. of } \\
\text { analyses/ } \\
\text { No. of } \\
\text { censored } \\
\text { values }\end{array}$ & $\begin{array}{l}\text { Minimum } \\
\text { value }\end{array}$ & $\begin{array}{l}\text { Median } \\
\text { value }\end{array}$ & $\begin{array}{l}\text { Maximum } \\
\text { value }\end{array}$ & $\begin{array}{l}\text { AZDE0 } \\
\text { standard } \\
\text { or Federal } \\
\text { criteria } \\
\text { (Use })^{3}\end{array}$ & $\begin{array}{c}\text { No. of standard } \\
\text { exceedances/ } \\
\text { No. of analyses/ } \\
\text { No. of sites } \\
\text { with ex- } \\
\text { ceedances }\end{array}$ \\
\hline \multicolumn{8}{|c|}{ Field properties (1967-2003) } \\
\hline Headwater creeks ${ }^{4}$ & \multirow{3}{*}{$\begin{array}{l}\text { Acid neutralizing capacity } \\
\quad\left(\mathrm{mg} / \mathrm{L} \mathrm{CaCO}_{3}\right)\end{array}$} & $76 / 0$ & 100 & 160 & 1,100 & \multirow{3}{*}{--} & \multirow{3}{*}{--} \\
\hline Headwater lakes ${ }^{5}$ & & $8 / 0$ & 80 & 110 & 190 & & \\
\hline Chinle Wash & & $4 / 0$ & 98 & 129 & 240 & & \\
\hline Headwater creeks & \multirow{3}{*}{ Dissolved oxygen (mg/L) } & $104 / 0$ & 5.3 & 7.10 & 13.3 & \multirow{3}{*}{$\begin{array}{l}7 \mathrm{~min} \\
(\mathrm{AWC})\end{array}$} & $29 / 60 / 7$ \\
\hline Headwater lakes & & $44 / 0$ & 4.0 & 6.25 & 13.9 & & $33 / 41 / 4$ \\
\hline Chinle Wash & & $3 / 0$ & 6 & 8.26 & 8.62 & & $1 / 3 / 1$ \\
\hline Headwater creeks & \multirow{3}{*}{$\mathrm{pH}(\mathrm{SU})$} & $115 / 0$ & 7 & 8.30 & 9.17 & \multirow{3}{*}{$\begin{array}{c}9, \mathrm{H} \\
6.5, \mathrm{~L} \\
(\mathrm{AWC})\end{array}$} & $\begin{array}{l}\mathbf{3 / 6 4 / 2}, \mathbf{H} \\
0 / 64 / 0, \mathrm{~L}\end{array}$ \\
\hline Headwater lakes & & $47 / 0$ & 8.14 & 8.94 & 9.96 & & $\begin{array}{c}\text { 22/45/3, H } \\
0 / 45 / 0, \mathrm{~L}\end{array}$ \\
\hline Chinle Wash & & $4 / 0$ & 7.4 & 8.08 & 8.32 & & $\begin{array}{l}0 / 3 / 0, \mathrm{H} \\
0 / 3 / 0, \mathrm{~L}\end{array}$ \\
\hline Headwater creeks & \multirow{3}{*}{$\begin{array}{l}\text { Specific conductance } \\
\quad(\mu \mathrm{S} / \mathrm{cm})\end{array}$} & $111 / 0$ & 105 & 334 & 560 & \multirow{3}{*}{--} & \multirow{3}{*}{--} \\
\hline Headwater lakes & & $44 / 0$ & 162 & 179 & 443 & & \\
\hline Chinle Wash & & $4 / 0$ & 219 & 300 & 334 & & \\
\hline Headwater creeks & \multirow{2}{*}{ Streamflow $\left(\mathrm{ft}^{3} / \mathrm{s}\right)$} & $35 / 1$ & $<1$ & 1.54 & 19.4 & \multirow{2}{*}{--} & \multirow{2}{*}{--} \\
\hline Chinle Wash & & $2 / 0$ & 1.56 & 24.8 & 48 & & \\
\hline Headwater creeks & \multirow{3}{*}{ Turbidity (NTU) } & $111 / 0$ & 0.69 & 8.64 & 1,000 & \multirow{3}{*}{$\begin{array}{c}10 \\
(\mathrm{AWC})\end{array}$} & $28 / 63 / 7$ \\
\hline Headwater lakes & & $2 / 0$ & 1.5 & 3.95 & 6.4 & & $0 / 1 / 0$ \\
\hline Chinle Wash & & $3 / 0$ & 1,000 & 1,000 & 1,000 & & $3 / 3 / 1$ \\
\hline Headwater creeks & \multirow{3}{*}{$\begin{array}{l}\text { Water temperature } \\
\qquad(\operatorname{deg} C)\end{array}$} & $113 / 0$ & 1.8 & 17.8 & 29 & \multirow{3}{*}{--} & \multirow{3}{*}{--} \\
\hline Headwater lakes & & $44 / 0$ & 15.8 & 18.1 & 21.4 & & \\
\hline Chinle Wash & & $3 / 0$ & 13.3 & 14.9 & 29.4 & & \\
\hline \multicolumn{8}{|c|}{ Nutrients, aggregated ${ }^{6}(1971-2003)$} \\
\hline Headwater creeks & \multirow{3}{*}{$\begin{array}{l}\text { Ammonia, unfiltered } \\
\text { (mg/L as } \mathrm{N})\end{array}$} & $89 / 68$ & $<.05$ & 0.045 & 1 & \multirow{3}{*}{$\begin{array}{l}\text { TVS } \\
\text { (AWC) }\end{array}$} & $0 / 55 / 0$ \\
\hline Headwater lakes & & $14 / 8$ & $<.5$ & .114 & 0.63 & & $0 / 13 / 0$ \\
\hline Chinle Wash & & $3 / 1$ & $<.5$ & -- & 1.2 & & $0 / 3 / 0$ \\
\hline Headwater creeks & \multirow{2}{*}{$\begin{array}{l}\text { Ammonia, un-ionized } \\
\quad(\mathrm{mg} / \mathrm{L} \text { as } \mathrm{N})\end{array}$} & $24 / 0$ & .0002 & .007 & .247 & \multirow{2}{*}{-- } & \multirow{2}{*}{--} \\
\hline Headwater lakes & & $2 / 0$ & .002 & .009 & .015 & & \\
\hline
\end{tabular}


Table 14. Statistical summary of water-quality data and exceedances of water-quality standards in selected surface-water sampling sites located in, near, and upstream from Canyon de Chelly National Monument, Arizona, 1967 to 2003. -Continued

[AWC, aquatic cold water; AZDEQ, Arizona Department of Environmental Quality; col/100 mL, colonies per 100 milliliters; Cr III, chromium III; deg C, degrees Celsius; DWP, drinking-water protected use; EPA RC III, U.S. Environmental Protection Agency National Recommended Nutrient Criteria for Ecoregion III; FBC, full-body contact; FC, fish consumption; fil, filtered; $\mathrm{ft}^{3} / \mathrm{s}$, cubic feet per second; GM, geometric mean; H, high (maximum) standard; I, instantaneous; L, low (minimum) standard; mg/L, milligrams per liter; MPN, most probable number; N, nitrogen; No., number; NTU, nephelometric turbidity units; P, phosphorus; pCi/L, picocuries per liter; POR, period of record; rec, recoverable; SS, suspended sediment concentrations (at or near baseflow only); SU, standard units; TVS, table value standard; unfil, unfiltered; unsp, unspeciated; $\mu \mathrm{S} / \mathrm{cm}$, microsiemens per centimeter; <, less than; >, greater than; ,-- not available or not computed; bold type indicates exceedance during recent POR]

\begin{tabular}{|c|c|c|c|c|c|c|c|}
\hline \multirow[b]{2}{*}{$\begin{array}{l}\text { Selected } \\
\text { surface-water } \\
\text { sites (see figure } 7 \\
\text { for location } \\
\text { of sites) }\end{array}$} & \multirow[b]{2}{*}{$\begin{array}{l}\text { Field property } \\
\text { or constituent } \\
\text { (reporting units) }\end{array}$} & \multicolumn{4}{|c|}{$\begin{array}{c}\text { Complete POR } \\
1967 \text { to } 2003^{1}\end{array}$} & \multicolumn{2}{|c|}{$\begin{array}{l}\text { Recent POR } \\
1988 \text { to } 2003^{2}\end{array}$} \\
\hline & & $\begin{array}{l}\text { No. of } \\
\text { analyses/ } \\
\text { No. of } \\
\text { censored } \\
\text { values }\end{array}$ & $\begin{array}{l}\text { Minimum } \\
\text { value }\end{array}$ & $\begin{array}{l}\text { Median } \\
\text { value }\end{array}$ & $\begin{array}{l}\text { Maximum } \\
\text { value }\end{array}$ & $\begin{array}{l}\text { AZDEQ } \\
\text { standard } \\
\text { or Federal } \\
\text { criteria } \\
\text { (Use })^{3}\end{array}$ & $\begin{array}{l}\text { No. of standard } \\
\text { exceedances/ } \\
\text { No. of analyses/ } \\
\text { No. of sites } \\
\text { with ex- } \\
\text { ceedances }\end{array}$ \\
\hline \multicolumn{8}{|c|}{ Nutrients, aggregated ${ }^{6}(1971-2003)$-Continued } \\
\hline Headwater creeks & \multirow{3}{*}{ Nitrate $(\mathrm{mg} / \mathrm{L}$ as $\mathrm{N})$} & $91 / 79$ & $<.05$ & .042 & 0.76 & \multirow{3}{*}{$\begin{array}{r}2,240(\mathrm{FBC}) \\
10(\mathrm{DWP})\end{array}$} & $0 / 55 / 0$ \\
\hline Headwater lakes & & $15 / 13$ & $<.05$ & -- & .2 & & $0 / 13 / 0$ \\
\hline Chinle Wash & & $3 / 1$ & $<.2$ & .21 & .26 & & $0 / 3 / 0$ \\
\hline Headwater creeks & \multirow{2}{*}{$\begin{array}{l}\text { Nitrogen, unfiltered } \\
\quad(\mathrm{mg} / \mathrm{L} \text { as } \mathrm{N})\end{array}$} & $51 / 45$ & $<1.7$ & .272 & $>1.9$ & $\begin{array}{c}0.38 \\
\text { EPA RC III }\end{array}$ & $6 / 51 / 4$ \\
\hline Headwater lakes & & $12 / 10$ & $<.95$ & -- & 1.21 & $\begin{array}{l}0.40 \\
\text { EPA RC III }\end{array}$ & $2 / 12 / 2$ \\
\hline Headwater creeks & \multirow{3}{*}{$\begin{array}{l}\text { Orthophosphorus } \\
\qquad(\mathrm{mg} / \mathrm{L} \text { as } \mathrm{P})\end{array}$} & $88 / 29$ & $<.02$ & .08 & 3 & \multirow{3}{*}{--} & \multirow{3}{*}{--} \\
\hline Headwater lakes & & $14 / 9$ & $<.01$ & .031 & .18 & & \\
\hline Chinle Wash & & $3 / 2$ & $<.1$ & -- & .06 & & \\
\hline Headwater creeks & \multirow{3}{*}{$\begin{array}{l}\text { Total phosphorus, } \\
\text { unfiltered (mg/L as } \mathrm{P})\end{array}$} & $90 / 14$ & $<.1$ & .145 & 1.6 & $\begin{array}{l}0.022 \\
\text { EPA RC III }\end{array}$ & $76 / 90 / 17$ \\
\hline Headwater lakes & & $12 / 10$ & $<.2$ & -- & .26 & $\begin{array}{c}0.017 \\
\text { EPA RC III }\end{array}$ & $2 / 12 / 2$ \\
\hline Chinle Wash & & $4 / 0$ & .01 & .785 & 1.6 & $\begin{array}{c}0.022 \\
\text { EPA RC III }\end{array}$ & $3 / 4 / 1$ \\
\hline \multicolumn{8}{|c|}{ Bacteriological data (1995-2001) } \\
\hline Headwater creeks & $\begin{array}{l}\text { Escherichia coli }(\text { E. coli) } \\
\quad(\mathrm{MPN} / 100 \mathrm{~mL})\end{array}$ & $13 / 6$ & 2 & $\begin{array}{c}83 \\
(\mathrm{GM})\end{array}$ & $>1,600$ & $\begin{array}{l}235, \mathrm{I} \\
(\mathrm{FBC})\end{array}$ & $4 / 13 / 4$ \\
\hline Headwater creeks & $\begin{array}{l}\text { Fecal coliform } \\
\quad(\mathrm{col} / 100 \mathrm{~mL})\end{array}$ & $31 / 0$ & 0 & $\begin{array}{c}16.1 \\
(\mathrm{GM}) \\
--\end{array}$ & 500 & -- & -- \\
\hline Headwater creeks & $\begin{array}{l}\text { Total coliform } \\
\quad(\mathrm{col} / 100 \mathrm{~mL}) \\
\end{array}$ & $38 / 3$ & 9.2 & $\begin{array}{c}211 \\
(\mathrm{GM}) \\
\end{array}$ & $>1,600$ & -- & -- \\
\hline \multicolumn{8}{|c|}{ Other constituents (1995-2003) } \\
\hline Headwater creeks & \multirow{2}{*}{$\begin{array}{l}\text { Chlorine, total residual } \\
\text { (mg/L) }\end{array}$} & $13 / 12$ & $<.05$ & -- & .15 & \multirow{2}{*}{.005 (AWC) } & $1 / 13 / 1$ \\
\hline Chinle Wash & & $2 / 2$ & $<.05$ & -- & $<.05$ & & $0 / 2 / 0$ \\
\hline Headwater creeks & \multirow{2}{*}{ Dissolved solids (mg/L) } & $55 / 0$ & 51 & 190 & 330 & \multirow[t]{2}{*}{--} & \multirow[t]{2}{*}{--} \\
\hline Headwater lakes & & $44 / 0$ & 104 & 118 & 292 & & \\
\hline Headwater creeks & \multirow{3}{*}{$\begin{array}{l}\text { Suspended solids (dried at } \\
\quad 110 \mathrm{deg} \mathrm{C}, \mathrm{mg} / \mathrm{L} \text { ) }\end{array}$} & $27 / 10$ & $<10$ & 13.0 & 1,000 & \multirow{3}{*}{$\begin{array}{l}80, \mathrm{SS}^{7} \\
(\mathrm{AWC})\end{array}$} & 2/13/1 \\
\hline Headwater lakes & & $12 / 11$ & $<10$ & -- & 17 & & $0 / 12 / 0$ \\
\hline Chinle Wash & & $2 / 0$ & 1,300 & 1,800 & 2,300 & & $2 / 2 / 1$ \\
\hline
\end{tabular}


Table 14. Statistical summary of water-quality data and exceedances of water-quality standards in selected surface-water sampling sites located in, near, and upstream from Canyon de Chelly National Monument, Arizona, 1967 to 2003.-Continued

[AWC, aquatic cold water; AZDEQ, Arizona Department of Environmental Quality; col/100 mL, colonies per 100 milliliters; Cr III, chromium III; $\operatorname{deg}$ C, degrees Celsius; DWP, drinking-water protected use; EPA RC III, U.S. Environmental Protection Agency National Recommended Nutrient Criteria for Ecoregion III; FBC, full-body contact; FC, fish consumption; fil, filtered; $\mathrm{ft}^{3} / \mathrm{s}$, cubic feet per second; GM, geometric mean; $\mathrm{H}$, high (maximum) standard; I, instantaneous; L, low (minimum) standard; mg/L, milligrams per liter; MPN, most probable number; N, nitrogen; No., number; NTU, nephelometric turbidity units; P, phosphorus; pCi/L, picocuries per liter; POR, period of record; rec, recoverable; SS, suspended sediment concentrations (at or near baseflow only); SU, standard units; TVS, table value standard; unfil, unfiltered; unsp, unspeciated; $\mu \mathrm{S} / \mathrm{cm}$, microsiemens per centimeter; $<$, less than; >, greater than; ,-- not available or not computed; bold type indicates exceedance during recent POR]

\begin{tabular}{|c|c|c|c|c|c|c|c|}
\hline \multirow[b]{2}{*}{$\begin{array}{l}\text { Selected } \\
\text { surface-water } \\
\text { sites (see figure } 7 \\
\text { for location } \\
\text { of sites) }\end{array}$} & \multirow[b]{2}{*}{$\begin{array}{l}\text { Field property } \\
\text { or constituent } \\
\text { (reporting units) }\end{array}$} & \multicolumn{4}{|c|}{$\begin{array}{c}\text { Complete POR } \\
1967 \text { to } 2003^{1}\end{array}$} & \multicolumn{2}{|c|}{$\begin{array}{l}\text { Recent POR } \\
1988 \text { to } 2003^{2}\end{array}$} \\
\hline & & $\begin{array}{l}\text { No. of } \\
\text { analyses/ } \\
\text { No. of } \\
\text { censored } \\
\text { values }\end{array}$ & $\begin{array}{l}\text { Minimum } \\
\text { value }\end{array}$ & $\begin{array}{l}\text { Median } \\
\text { value }\end{array}$ & $\begin{array}{l}\text { Maximum } \\
\text { value }\end{array}$ & $\begin{array}{l}\text { AZDEQ } \\
\text { standard } \\
\text { or Federal } \\
\text { criteria } \\
(\text { Use })^{3}\end{array}$ & $\begin{array}{c}\text { No. of standard } \\
\text { exceedances/ } \\
\text { No. of analyses/ } \\
\text { No. of sites } \\
\text { with ex- } \\
\text { ceedances }\end{array}$ \\
\hline \multicolumn{8}{|c|}{ Trace elements (1970-2003) (Results reported in micrograms per liter) } \\
\hline Headwater creeks & \multirow{3}{*}{ Aluminum, fil } & $27 / 18$ & $<.1$ & .031 & .11 & \multirow{3}{*}{$\begin{array}{c}87 \text { fil } \\
\text { NAWQ }\end{array}$} & \multirow{3}{*}{--} \\
\hline Headwater lakes & & $14 / 4$ & $<.025$ & .040 & 40 & & \\
\hline Chinle Wash & & $2 / 0$ & .08 & .086 & .093 & & \\
\hline Headwater creeks & \multirow{2}{*}{ Arsenic, fil } & $83 / 71$ & $<.003$ & .002 & 4.9 & \multirow{2}{*}{$190(\mathrm{AWC})$} & $0 / 48 / 0$ \\
\hline Headwater lakes & & $14 / 7$ & $<.005$ & .004 & 2 & & $0 / 13 / 0$ \\
\hline \multirow{2}{*}{ Headwater creeks } & Barium, fil & $68 / 6$ & $<.002$ & .12 & 260 & \multirow{4}{*}{$\begin{array}{l}98,000 \text { fil } \\
\text { (FBC) }\end{array}$} & $0 / 40 / 0$ \\
\hline & Barium, unfil rec & $9 / 0$ & 52 & 100 & 190 & & -- \\
\hline Headwater lakes & \multirow{2}{*}{ Barium, fil } & $6 / 0$ & .051 & .20 & 91 & & $0 / 5 / 0$ \\
\hline Chinle Wash & & $2 / 0$ & .099 & .13 & .16 & & $0 / 2 / 0$ \\
\hline Headwater creeks & Cadmium, fil & $81 / 78$ & $<.5$ & -- & .098 & $\begin{array}{c}\text { TVS } \\
\text { (AWC) }\end{array}$ & $0 / 13 / 0$ \\
\hline Headwater creeks & Chromium unsp, fil & $83 / 81$ & $<2$ & -- & 1.6 & $\begin{array}{c}\text { TVS } \\
\text { (AWC, Cr III) }\end{array}$ & $0 / 14 / 0$ \\
\hline \multirow{2}{*}{$\begin{array}{l}\text { Headwater creeks } \\
\text { Headwater lakes }\end{array}$} & \multirow{2}{*}{ Copper, fil } & $77 / 67$ & $<4$ & 2.34 & 15 & \multirow{2}{*}{$\begin{array}{c}\text { TVS } \\
\text { (AWC) }\end{array}$} & $1 / 12 / 1$ \\
\hline & & $14 / 9$ & $<1$ & 1.00 & 11 & & $1 / 13 / 1$ \\
\hline \multirow{2}{*}{ Headwater creeks } & Iron, fil & $39 / 29$ & $<4$ & 7.00 & 100 & \multirow{4}{*}{$\begin{array}{l}1,000 \text { fil } \\
\text { NAWQ }\end{array}$} & \multirow{4}{*}{-} \\
\hline & Iron, unfil rec & $3 / 0$ & 40 & 100 & 180 & & \\
\hline Headwater lakes & \multirow{2}{*}{ Iron, fil } & $3 / 0$ & 24 & 25 & 40 & & \\
\hline Chinle Wash & & $1 / 0$ & 10 & 10 & 10 & & \\
\hline Headwater creeks & Lead, fil & $76 / 74$ & $<2$ & -- & $<50$ & $\begin{array}{c}\text { TVS } \\
\text { (AWC) }\end{array}$ & $0 / 11 / 0$ \\
\hline Headwater creeks & $\begin{array}{l}\text { Manganese, fil } \\
\text { Manganese, unfil rec }\end{array}$ & $\begin{array}{c}39 / 38 \\
3 / 1\end{array}$ & $\begin{array}{l}<1 \\
<5\end{array}$ & -- & $\begin{array}{r}<50 \\
17\end{array}$ & $\begin{array}{c}\text { 196,000 unfil } \\
\text { (FBC) }\end{array}$ & $\begin{array}{c}-- \\
0 / 3 / 0\end{array}$ \\
\hline Headwater lakes & Manganese, fil & $2 / 0$ & 5 & 5 & 5 & $\begin{array}{l}120 \text { fil } \\
\text { Tier II }\end{array}$ & -- \\
\hline Headwater creeks & Mercury, unfil rec & $47 / 46$ & $<.2$ & -- & $<1$ & $\begin{array}{c}420(\mathrm{FBC}) \\
0.6(\mathrm{FC})\end{array}$ & $0 / 26 / 0$ \\
\hline Headwater creeks & Nickel fi & $74 / 66$ & $<4$ & 2.49 & $<50$ & TVS & $0 / 12 / 0$ \\
\hline Headwater lakes & NICKel, III & $14 / 8$ & $<10$ & 1.96 & 4 & (AWC) & $0 / 13 / 0$ \\
\hline
\end{tabular}


Table 14. Statistical summary of water-quality data and exceedances of water-quality standards in selected surface-water sampling sites located in, near, and upstream from Canyon de Chelly National Monument, Arizona, 1967 to 2003.-Continued

[AWC, aquatic cold water; AZDEQ, Arizona Department of Environmental Quality; col/100 mL, colonies per 100 milliliters; Cr III, chromium III; deg C, degrees Celsius; DWP, drinking-water protected use; EPA RC III, U.S. Environmental Protection Agency National Recommended Nutrient Criteria for Ecoregion III; FBC, full-body contact; FC, fish consumption; fil, filtered; $\mathrm{ft}^{3} / \mathrm{s}$, cubic feet per second; GM, geometric mean; H, high (maximum) standard; I, instantaneous; L, low (minimum) standard; mg/L, milligrams per liter; MPN, most probable number; N, nitrogen; No., number; NTU, nephelometric turbidity units; P, phosphorus; pCi/L, picocuries per liter; POR, period of record; rec, recoverable; SS, suspended sediment concentrations (at or near baseflow only); SU, standard units; TVS, table value standard; unfil, unfiltered; unsp, unspeciated; $\mu \mathrm{S} / \mathrm{cm}$, microsiemens per centimeter; <, less than; >, greater than; ,-- not available or not computed; bold type indicates exceedance during recent POR]

\begin{tabular}{|c|c|c|c|c|c|c|c|}
\hline \multirow[b]{2}{*}{$\begin{array}{l}\text { Selected } \\
\text { surface-water } \\
\text { sites (see figure } 7 \\
\text { for location } \\
\text { of sites) }\end{array}$} & \multirow[b]{2}{*}{$\begin{array}{l}\text { Field property } \\
\text { or constituent } \\
\text { (reporting units) }\end{array}$} & \multicolumn{4}{|c|}{$\begin{array}{c}\text { Complete POR } \\
1967 \text { to } 2003^{1}\end{array}$} & \multicolumn{2}{|c|}{$\begin{array}{l}\text { Recent POR } \\
1988 \text { to } 2003^{2}\end{array}$} \\
\hline & & $\begin{array}{l}\text { No. of } \\
\text { analyses/ } \\
\text { No. of } \\
\text { censored } \\
\text { values }\end{array}$ & $\begin{array}{l}\text { Minimum } \\
\text { value }\end{array}$ & $\begin{array}{l}\text { Median } \\
\text { value }\end{array}$ & $\begin{array}{l}\text { Maximum } \\
\text { value }\end{array}$ & $\begin{array}{l}\text { AZDE0 } \\
\text { standard } \\
\text { or Federal } \\
\text { criteria } \\
\text { (Use })^{3}\end{array}$ & $\begin{array}{c}\text { No. of standard } \\
\text { exceedances/ } \\
\text { No. of analyses/ } \\
\text { No. of sites } \\
\text { with ex- } \\
\text { ceedances }\end{array}$ \\
\hline \multicolumn{8}{|c|}{ Trace elements (1970-2003) (Results reported in micrograms per liter)-Continued } \\
\hline Headwater creeks & $\begin{array}{l}\text { Selenium, fil } \\
\text { Selenium, unfil }\end{array}$ & $\begin{array}{l}72 / 67 \\
47 / 44\end{array}$ & $\begin{array}{l}<3 \\
<4\end{array}$ & $\begin{array}{l}1.18 \\
1.54\end{array}$ & $\begin{array}{l}<60 \\
<60\end{array}$ & $\begin{array}{l}5 \text { fil NAWQ } \\
2 \text { unfil rec } \\
\text { (AWC) }\end{array}$ & $\begin{array}{l}0 / 42 / 0 \\
0 / 25 / 0\end{array}$ \\
\hline Headwater creeks & Silver, fil & $77 / 76$ & $<50$ & -- & 25 & $\begin{array}{c}\text { TVS } \\
(\mathrm{AWC})^{7}\end{array}$ & $1 / 12 / 1$ \\
\hline Headwater lakes & Strontium, fil & $2 / 0$ & 240 & 255 & 270 & $\begin{array}{l}\text { 1,500 fil } \\
\text { Tier II }\end{array}$ & -- \\
\hline Headwater creeks & $\begin{array}{l}\text { Uranium, fil } \\
\text { Uranium, fil (pCi/L) }\end{array}$ & $\begin{array}{l}1 / 0 \\
2 / 0\end{array}$ & $\begin{array}{l}.18 \\
1.9\end{array}$ & $\begin{array}{l}-- \\
2.2\end{array}$ & $\begin{array}{l}.18 \\
2.4\end{array}$ & $\begin{array}{c}35 \text { (DWP) } \\
--\end{array}$ & $\begin{array}{c}0 / 1 / 0 \\
--\end{array}$ \\
\hline $\begin{array}{l}\text { Headwater creeks } \\
\text { Headwater lakes }\end{array}$ & Zinc, fil & $\begin{array}{l}78 / 72 \\
13 / 10\end{array}$ & $\begin{array}{l}<5 \\
<10\end{array}$ & $\begin{array}{l}37.7 \\
6.87\end{array}$ & $\begin{array}{c}140 \\
62\end{array}$ & $\begin{array}{c}\text { TVS } \\
\text { (AWC) }\end{array}$ & $\begin{array}{l}0 / 12 / 0 \\
0 / 12 / 0\end{array}$ \\
\hline
\end{tabular}

1 "Complete POR" data include all available data. "Recent POR" data only include exceedance results for sampling sites with data on these same waters located within the State of Arizona (that is, headwater sites located in New Mexico that fall under New Mexico standards are not included in the exceedance analysis). POR varies with constituent and site.

${ }^{2}$ Last 15 years of available data (for sites located within Arizona) considered for standards exceedance analysis (that is, all samples collected on or after January 1, 1988, through December 31, 2003). POR varies with constituent and site.

${ }^{3}$ State standards and designated beneficial uses from the State of Arizona Administrative Code (2002). Selected Federal criteria are used when State standards are not established, including the USEPA National Recommended Nutrient Criteria for Ecoregions II and III (U.S. Environmental Protection Agency, 2002), the National Ambient Water Quality criteria (NAWQ), or the secondary chronic Tier II values (Suter and Tsao, 1996).

${ }^{4}$ Includes available data from sampling sites on Tsaile, Wheatfields, Whiskey, Monument, and Crystal Creeks located within the States of Arizona and New Mexico.

${ }^{5}$ Includes all available data from Tsaile and Wheatfields Lakes; includes data collected from multiple depths sampled on the same day, in some cases, for the same constituent.

${ }^{6}$ Aggregated nutrients based on Mueller and others (1995); where sample fraction not stated, aggregation includes both filtered and unfiltered concentrations. Zero values were excluded unless converted to a value of less than the censoring level.

${ }^{7}$ Suspended-sediment standard used as comparison to suspended-solids data (no suspended-sediment data available for these waters); acute TVS standard used for comparison for filtered silver (no chronic standard established in Arizona). 
one of three Chinle Wash measurements, and 80 percent all Tsaile and Wheatfields Lake measurements (33 of 41 values) were less than $7 \mathrm{mg} / \mathrm{L}$. Low DO values of 4.0 and $5.3 \mathrm{mg} / \mathrm{L}$ were measured in the headwater creeks and lakes. The low DO measurements in the lakes, all made from July through September, were taken at various depths ranging from the surface to a maximum depth of $13.1 \mathrm{ft}$. The lowest DO readings from a given measurement event were generally not correlated with the measurement made at the deepest depth. Low DO, which can stress fish and macroinvertebrate populations, may be a result of high stream temperatures, stratification in lakes and reservoirs that produce anoxic conditions at depth, high salinity, elevated turbidity levels (which reduces photosynthetic activity), atmospheric pressure, and (or) increased organic contaminant concentrations.

Measurements of $\mathrm{pH}$ exceeding the 9-SU aquatic coldwater fisheries standard were observed in 22 of 45 measurements made from the headwater lakes (21 from Tsaile Lake and 1 from Wheatfields Lake) and ranged from 9.11 to $9.96 \mathrm{SU}$. Three measurements from Wheatfields Creek also exceeded the $\mathrm{pH}$ standard of $9 \mathrm{SU}$ and ranged from 9.1 to $9.17 \mathrm{SU}$. The predominantly sandstone-derived calcium bicarbonate and carbonate waters in the creeks and lakes in and upstream from the monument are a potential cause of the elevated $\mathrm{pH}$ values.

Nearly one-half of all recent turbidity measurements (28 of 63) from Tsaile and Wheatfields Creeks exceeded the aquatic cold-water fisheries standard of $10 \mathrm{NTU}$; these elevated turbidity values ranged from 11.8 to 1,000 NTU. No other measurements from headwater streams indicated high turbidity. Elevated turbidity values of 1,000 NTU also were observed for the three recent measurements made at Chinle Wash. Elevated turbidity could be a result of stream channel downcutting and erosion and other sources that can result in increased suspended solids (for example, from erosion of silt and clays, sewage, and algal blooms). Erosion and channel incision have been identified as water-quality concerns by park personnel and documented by the NRCS in previous studies; likewise, the potential for excess nutrients exists in the watershed from overgrazing of riparian areas and encroaching residential development activities (Thomas and others, 2006; Natural Resources Conservation Service, 1999).

While water temperature is not currently regulated by the State of Arizona, water temperatures equal to or exceeding $25^{\circ} \mathrm{C}$ (the standard for a marginal cold-water fishery in New Mexico) were measured in Tsaile Creek, Whiskey Creek, and Chinle Wash. These measurements were made from mid-July to mid-September, when temperatures would be expected to be elevated.

\section{Major lons}

The predominant water type for the surface-water-quality sites is calcium bicarbonate with some carbonate, magnesium, potassium, and sodium (fig. 9). Some samples indicate higher concentrations of magnesium and lower concentrations of calcium in headwater creeks and lakes than in Chinle Wash, which may well be a signature from the Chuska Sandstone source rocks. Generally the waters are of similar water type upstream from, within, and downstream from the monument.

\section{Nutrients}

Samples that were analyzed for selected nutrients, including ammonia (unfiltered and un-ionized), nitrate (unfiltered and filtered), total nitrogen (unfiltered), orthophosphorus (unfiltered and filtered), and total phosphorus (unfiltered) were collected between 24 and 91 times from 17 sites in the headwater creeks. Tsaile and Wheatfields Lakes had nutrients analyzed in 2 to 15 samples from five sites, with multiple depths sampled during a single day's sampling event. Only three or four samples collected from two sites in Chinle Wash were analyzed for nutrients (unfiltered ammonia, nitrate, and orthophosphorus or total phosphorus). No concentrations exceeded the Arizona aquatic cold-water fisheries standards for unfiltered ammonia or nitrate (table 14).

The USEPA-recommended nutrient criteria for total nitrogen are $0.38 \mathrm{mg} / \mathrm{L}$ in rivers and streams and $0.40 \mathrm{mg} / \mathrm{L}$ for lakes and reservoirs in aggregate Ecoregion III. Analyses of six (of 51 analyses) and two (of 12 analyses) total nitrogen (unfiltered) samples collected from the headwater creeks and lakes, respectively, exceeded the recommended criteria, and concentrations ranged from greater than 0.50 to greater than $1.9 \mathrm{mg} / \mathrm{L}$. No total nitrogen data were available to evaluate for Chinle Wash. A majority (45 of 51 analyses for headwater creeks and 10 of 12 analyses for headwater lakes) of the total nitrogen analyses of samples from the headwater creeks and lakes had censoring levels that were greater than the recommended total nitrogen criteria levels.

While Arizona has not established in-stream standards for total phosphorus, the USEPA has recommended that total phosphorus concentrations be less than $0.022 \mathrm{mg} / \mathrm{L}$ in rivers and streams and less than $0.017 \mathrm{mg} / \mathrm{L}$ for lakes and reservoirs for controlling eutrophication in aggregate Ecoregion III, which includes CACH (U.S. Environmental Protection Agency, 2002). Analyses of 76 headwater creek samples (of 90 recent samples) for total phosphorus (unfiltered) had concentrations ranging from 0.041 to $1.6 \mathrm{mg} / \mathrm{L}$, and three analyses of samples from Chinle Wash had total phosphorus (unfiltered) concentrations ranging from 0.65 to $1.6 \mathrm{mg} / \mathrm{L}$, which exceeded the recommended total phosphorus criterion for rivers and streams. Two analyses of samples from Wheatfields Lake (of 12 samples from both reservoirs) exceeded the recommended total phosphorus criterion for lakes and reservoirs.

Elevated nutrient concentrations could be the result of grazing activities in the riparian areas, recreational activity on the reservoirs, natural erosion from sedimentary rocks (phosphorus), agricultural production in the riparian and upland areas, and residential development with individual septic systems encroaching on the monument. 


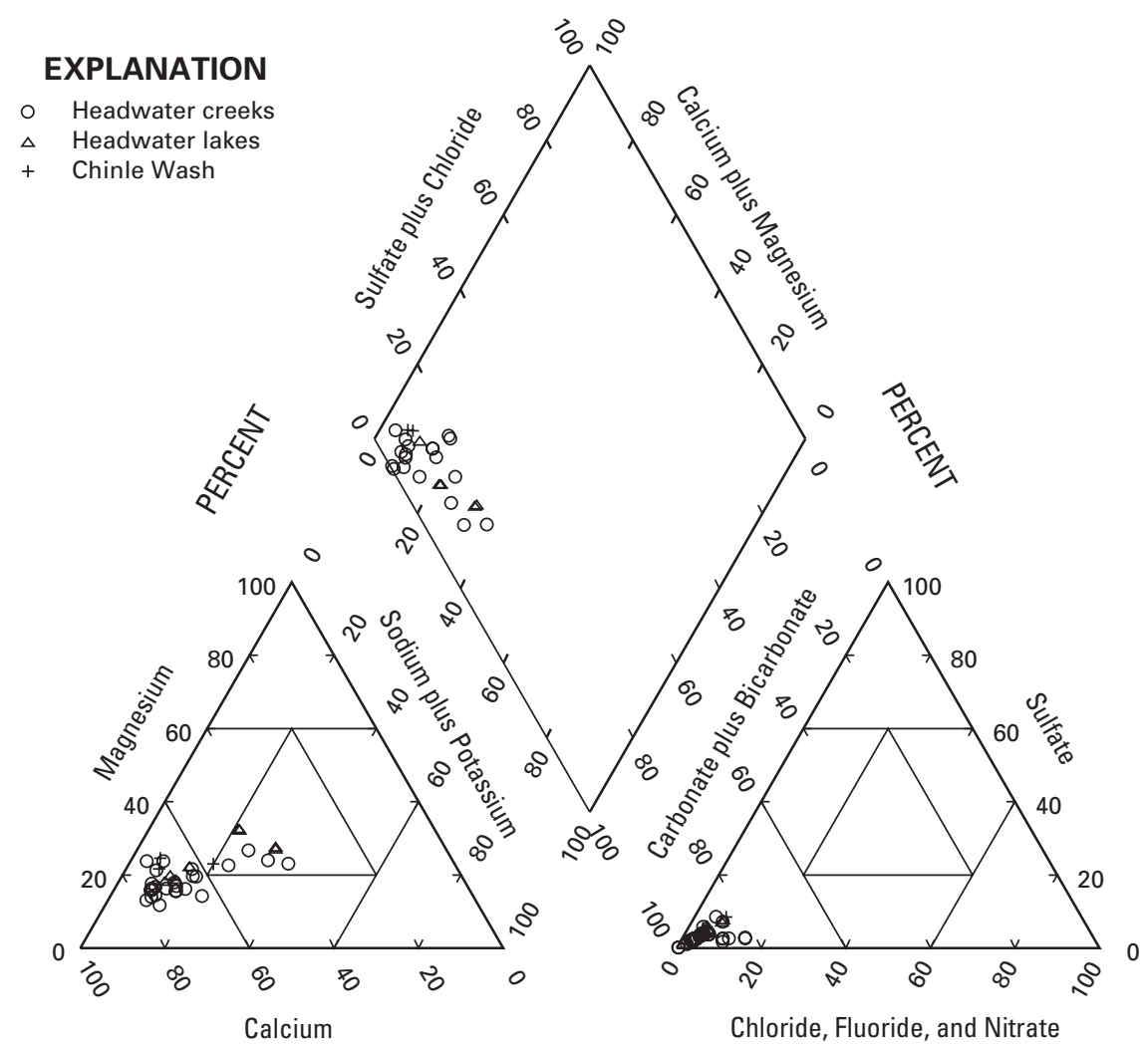

PERCENTAGE OF TOTAL MILLIEQUIVALENTS PER LITER

Figure 9. Water types for headwater creeks, headwater lakes, and Chinle Wash, Canyon de Chelly National Monument, Arizona, 1967 to 2003.

\section{Bacteriological Data}

Samples analyzed for selected bacteria, including Escherichia coli (E. coli), fecal coliform, and total coliform, were collected 13, 31, and 38 times (from 9, 8, and 12 sites, respectively) in headwater creeks. Tsaile and Wheatfields Lakes had nine samples collected and analyzed for fecal coliform. No samples were analyzed for bacteria from Chinle Wash. Four individual E. coli values exceeded the Arizona full-body contact standard of $235 \mathrm{col} / 100 \mathrm{~mL}$ (table 14). No Arizona standards exist for fecal or total coliform, though 1 and 16, respectively, of these results in the headwater creeks were high (equal to or greater than $500 \mathrm{col} / 100 \mathrm{~mL}$ ) indicating bacterial contamination. Contamination can occur from livestock, wildlife, and human activities occurring either directly in the creeks or riparian areas or on upland areas that contribute overland runoff to creeks during rainfall events. The lack of bacteriological data on Chinle Wash prohibits evaluating effects from the Navajo Canyon bottom dwellings and associated residential, grazing, and agricultural activities occurring within the monument.

\section{Other Constituents}

Thirteen samples from headwater creeks and two samples from Chinle Wash were analyzed for total residual chlorine (TRC), which is free available chlorine plus combined available chlorine. One value $(0.15 \mathrm{mg} / \mathrm{L})$ exceeded the Arizona aquatic cold-water fisheries standard set at $0.005 \mathrm{mg} / \mathrm{L}$, which is only three times the censoring level of $0.05 \mathrm{mg} / \mathrm{L}$ and could be attributed to analytical uncertainty. All other values were reported as below the censoring level. Additional analyses for TRC with censoring levels lower than the standard may be warranted. Elevated TRC concentrations may be indications of human contamination from leaking septic tanks (from households using bleach). TRC can be toxic to aquatic life at certain concentrations; toxicity increases with lower values of $\mathrm{pH}$ and (or) increasing temperature (U.S. Environmental Protection Agency Office of Water, 1999). Permissible concentrations and acute and chronic toxic effects of residual chlorine on aquatic organisms were reported by the U.S. Environmental Protection Agency Office of Water (1985).

No State standards for dissolved solids exist in Arizona; however, dissolved solids concentrations above $500 \mathrm{mg} / \mathrm{L}$ exceed the secondary drinking-water regulation guideline. 
Concentrations of dissolved solids represent all dissolved constituents in the water sample and did not approach or exceed $500 \mathrm{mg} / \mathrm{L}$ for any of the data (table 14 ).

Suspended-sediment concentration data were unavailable for any of the waters evaluated for $\mathrm{CACH}$; therefore, available suspended-solids data are summarized in table 14 to describe the extent of suspended material in the headwater creeks and lakes and in Chinle Wash. Concentrations of suspended solids were higher than the Arizona aquatic cold-water fisheries 80-mg/L standard for suspended sediment in four samples (two each in the headwater creeks and Chinle Wash). However, due to differing field sampling and analytical laboratory methodologies, suspended-solids concentrations are generally not comparable to suspended-sediment concentrations and should not be used interchangeably for data collected from natural water. Where sand-sized materials exceed 25 percent of the sediment dry weight, suspended-sediment concentrations tend to be larger than their corresponding suspended-solids values (Gray and others, 2000). Suspendedsolids concentrations were greater than $250 \mathrm{mg} / \mathrm{L}$ from one headwater creek sample $(1,000 \mathrm{mg} / \mathrm{L})$ and the two Chinle Wash samples (1,300 and 2,300 mg/L). Concentrations of suspended solids sampled from the headwater lakes were low (less than 10 to $17 \mathrm{mg} / \mathrm{L}$ ).

\section{Trace Elements}

Many samples that were analyzed for trace elements in headwater creeks and lakes and Chinle Wash had values below the censoring levels (table 14), and values above these levels were well below the applicable numeric criteria or chronic aquatic cold-water computed TVS. One analysis of filtered copper narrowly exceeded the chronic aquatic cold-water computed TVS $(7.16 \mu \mathrm{g} / \mathrm{L})$ in a sample from Tsaile Lake (11 $\mu \mathrm{g} / \mathrm{L}$ ) collected in September 2002; this value also exceeded the acute TVS $(10.5 \mu \mathrm{g} / \mathrm{L})$. One analysis of a sample collected in August 1996 from Tsaile Creek exceeded the acute aquatic cold-water computed TVS for filtered silver of $5.64 \mu \mathrm{g} / \mathrm{L}$ with a measured value of $25 \mu \mathrm{g} / \mathrm{L}$ (all other filtered silver values were nondetect). There is not a chronic aquatic-life TVS for filtered silver in Arizona. No other trace-element concentrations exceeded the numeric standard or calculated TVS.

As additional upland development and mining occur in the headwaters of the monument, monitoring for trace elements would allow the NPS to determine if these upstream activities are affecting water quality. Owing to the lack of data from Chinle Wash, it is not possible to determine if any activities occurring within the monument are contributing to increased trace-element concentrations.

\section{Summary of Surface-Water Characterization and Considerations for Monitoring}

Data available from the headwater creeks and lakes in $\mathrm{CACH}$ indicate reduced dissolved oxygen and elevated $\mathrm{pH}$ and turbidity levels, nutrients (unfiltered nitrogen and phosphorus), bacteriological counts (E. coli), suspended solids, and possibly elevated residual chlorine, though few data were available for this last constituent. Few data were available for Chinle Wash, which limits interpretation of changes in water quality occurring within the monument from natural sources or anthropogenic activities. In order to track changes in water quality and to determine if elevated concentrations are a concern, it would be helpful to incorporate routine stream and lake water-quality monitoring for core field properties and turbidity, coliforms, and nutrients. Analyzing samples for trace elements in Chinle Wash would fill a current data gap and help determine if upstream activities are affecting water quality.

\section{Chaco Culture National Historical Park, New Mexico}

Chaco Culture National Historical Park (CHCU) is a semiarid desert steppe (about 6,200 ft) in the northwestern corner of New Mexico in the center of the San Juan River Basin on the southeastern part of the Colorado Plateau. CHCU is renowned for its unique archeological ruins built between A.D. 850 and 1250. The archeological sites at CHCU are considered sacred homelands of Puebloan people of New Mexico, the Hopi Tribe, the Navajo Nation, and other Native American peoples of the Southwest (National Park Service, [n.d. a]; National Park Service, [n.d. b]). The prominent geomorphic feature of the park and the central feature along which most of the prehistoric sites are located is Chaco Canyon, which drains the valley from southeast to northwest and is characterized by a steep-walled canyon and gentle, sloping mesas (fig. 10). Chaco Wash becomes Chaco River near the park's northwest boundary and eventually flows into the San Juan River.

$\mathrm{CHCU}$ has a semiarid climate and is characterized by spring snowmelt-dominated runoff, a summer monsoonal season, and periods of drought. Climate station 291647 is about 18 mi east of the largest CHCU park unit at an elevation of $6,180 \mathrm{ft}$ (fig. 10). Mean annual precipitation is 8.9 inches (1922-2006) with August the wettest month (1.3 inches) and June the driest ( 0.4 inch) (Western Regional Climate Center, 2006). July through October is the monsoonal season in the park. Average annual snowfall is 14.6 inches. Average monthly air temperatures ranged from $28.2^{\circ} \mathrm{F}$ in January to $72.6^{\circ} \mathrm{F}$ in July, with an average annual temperature of $49.6^{\circ} \mathrm{F}$. Daily extremes ranged from $-38^{\circ} \mathrm{F}$ on December 12,1961 , to $104^{\circ} \mathrm{F}$ on July 26, 1979 (Western Regional Climate Center, 2006).

\section{Geology}

During the Late Cretaceous Period (approximately 75 to 80 million years ago), $\mathrm{CHCU}$ was part of the migrating coastline of the Western Interior Seaway that divided North America into two separate land areas. $\mathrm{CHCU}$ is underlain by Cretaceous sedimentary rocks that were derived from alternating marine and coastal or lowland environments. 


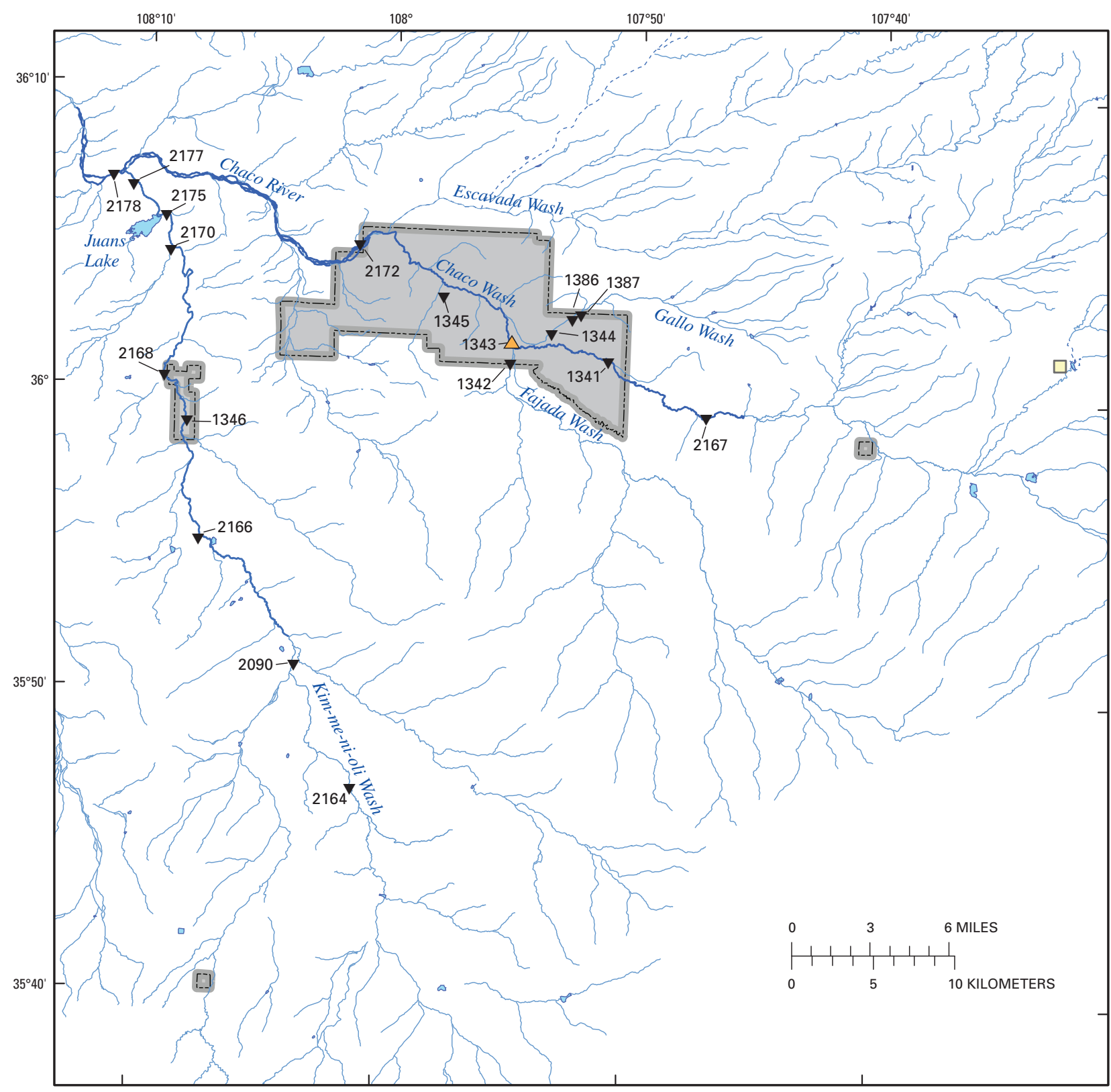

Base from U.S. Geological Survey digital data; surface water and lakes, ponds and reservoirs, 1:100,000; park boundary from the National Park Service, scale unspecified.

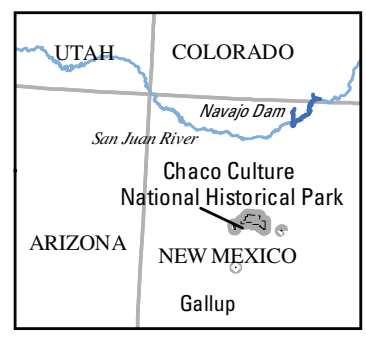

Location map

\section{EXPLANATION}

\begin{tabular}{|c|c|}
\hline Surf & ace water \\
\hline & Other (canals, diversions) \\
\hline & Intermittent or ephemeral \\
\hline & Chaco Wash, Chaco River, and Kim-me-ni-oli Wash \\
\hline & Lakes, ponds and reservoirs \\
\hline----- & Chaco Culture National Historical Park \\
\hline Sele & $\begin{array}{l}\text { ted water-quality sampling sites } \\
\text { Surface water }\end{array}$ \\
\hline 1342 & Site number \\
\hline$\triangle$ & Streamflow-gaging station (09367680) \\
\hline$\square$ & Climate station (291647) \\
\hline
\end{tabular}

Figure 10. Chaco Culture National Historical Park, New Mexico, and locations of water-quality sampling sites. 
Most of the rocks exposed in CHCU are from two subunits of the Mesaverde Group: the Menefee Formation, which is exposed at the edges of the valley floor and throughout the Kim-mi-ni-oli Wash drainage and the overlying Cliff House Sandstone, which forms the high cliffs in the park (Scott and others, 1984). Near the northern boundary of the park, the overlying Lewis Shale and Pictured Cliffs Sandstone are exposed (National Park Service, 2004). Alluvium, composed of fine-grained sediments of varying thickness, overlies the Mesaverde Group formations along Chaco Wash and its tributaries (Garland Moore, National Park Service, Southwest Region, written commun., [1972-1974?]; Martin, 2005).

The Menefee Formation is an erodible gray siltstone and mudstone interbedded with sandstone, carbonaceous shale, and variable amounts of coal (Baars, 2000). The resistant Cliff House Sandstone is a buff-colored marine sandstone interbedded with shales (www.nps.gov/chcu/geology.htm accessed March 13, 2006). The Lewis Shale is a thick black shale interbedded with thin beds of bentonite clay derived from volcanic ash eruptions (Scott and others, 1984; Baars, 2000). Younger Tertiary and Quaternary deposits, which have been mostly eroded away by wind, water, and mass wasting, followed similar flow paths as the present-day Chaco River channel that has been cut down to its current depth of $300 \mathrm{ft}$, leaving a series of alluvial terraces composed of varying amounts of gravel, sand, silt, and clay (Scott and others, 1984).

\section{Water Resources}

CHCU's main drainage, Chaco Wash, becomes Chaco River at the northwestern park boundary. The main canyon tributaries include Escavada, Fajada, and Gallo Washes, and several smaller secondary washes and arroyos (fig. 10). Chaco Wash is a narrow, sinuous channel that has incised into the valley floor by as much as $32 \mathrm{ft}$ since the 1930s (Gellis, 2002). These ephemeral or intermittent drainages cut through various alluvial deposits and support semiriparian vegetation critical for maintaining biodiversity in the region (Garland Moore, National Park Service, Southwest Region, written commun., [1972-1974?]; Scott and others, 1984; Thomas and others, 2006). Few springs are within the park, but these are considered important natural resources because of CHCU's waterlimited environment (Thomas and others, 2006).

Daily streamflow data were collected from 1976 to 1990 , at USGS Station 09367680 Chaco Wash at Chaco Canyon National Monument, New Mexico (site 1343; table 15). Mean monthly discharge range from $13.1 \mathrm{ft}^{3} / \mathrm{s}$ in February to $0.34 \mathrm{ft}^{3} / \mathrm{s}$ in December over the period 1979 to 1990. Peak flows were recorded from 1976 through 2003 with the highest flow recorded on August 23, 2003, at 4,970 ft $3 / \mathrm{s}$. Numerous periods of no flow were recorded during the time this station was operational. Total average annual runoff was 0.09 inch for water years 1983 to 1990 from the $578-\mathrm{mi}^{2}$ drainage basin (U.S. Geological Survey, 2001).
The highly porous and permeable sandstone units of the Mesaverde Group and Pictured Cliff Sandstone can be good sources of ground water (artesian in some cases) though water quality can be unpotable due to high dissolved solids (Baars, 2000; Garland Moore, National Park Service, Southwest Region, written commun., [1972-1974?]). Numerous attempts were made to tap the Chaco Wash alluvium for potable water supply; however, these efforts were largely unsuccessful due to the undesirable quality and yield from these shallow wells (Martin, 2005). The park's water supply is from a 3,095-ft artesian well in the maintenance yard that was drilled into the Gallup Sandstone aquifer in 1972 (Martin, 2005). The NPS currently monitors discharge at Chaco Wash at Chaco Canyon National Monument gaging station (09367680) and shallow ground water using a network of wells at three locations in the park (Stephen Monroe, National Park Service, written commun., 2007).

Mining (coal and uranium) activities along with oil and gas exploration, coal-bed methane extraction, power generation, and associated water and residential development in the area surrounding the park are considered potential concerns for surface- and ground-water quantity and quality in $\mathrm{CHCU}$ (Thomas and others, 2006; Martin, 2005). Coal has been and continues to be surface mined from the Menefee Formation in the vicinity of Gallup, New Mexico (southwest of the park), and from the Fruitland Formation, which overlies the exposed Mesaverde Group formations north of the park (Hejl, 1982; Baars, 2000). Past studies have shown the coal extraction occurring in the Fruitland Formation is hydrogeologically isolated from the park and therefore is not a concern for park resources, except where mining-affected surface runoff could affect water quality in the tributaries flowing into Chaco Wash and the Chaco River (Martin, 2005). Coal-fired electric-power generation in the region has the potential to affect regional precipitation quality (Goetz and others, 1987).

Erosion control is among the most critical resource needs of the park to protect its cultural resources (Thomas and others, 2006). Grazing in the surrounding contributing drainage areas could affect water quality where runoff and erosion occur; however, the main park area has been ungrazed for several years and is representative of desert grassland and semiriparian habitats in the San Juan Basin (Thomas and others, 2006).

\section{Available Water-Quality Data}

Water-quality data from 797 surface-water samples were collected by the USGS between January 1976 and October 1983. To evaluate water quality, the samples were divided into the following three stream groupings: (1) Chaco Wash and Chaco River, which flow through the center of the park; (2) three tributary washes to Chaco Canyon, including Escavada, Fajada, and Gallo Washes; and (3) Kim-me-ni-oli Wash, which flows through the western part of the park. Water-quality data 
Table 15. Stream sites with water-quality data in, upstream from, and downstream from Chaco Culture National Historical Park, New Mexico, 1976 to 1983.

[Br, bridge; DD, decimal degrees; E, east; EB, east boundary; Hwy, highway; KMNO, Kim-me-ni-oli; Lk, lake; Mi, mile; Mon, Monument; Natl, National; NM, New Mexico; No., number; Nr, near; PB, Pueblo Bonito; R, River; SE, southeast; S, south; Vis Ctr, visitor center; Site no. shown in figure 10; *, sites within the park boundary; site names retained from original source database]

\begin{tabular}{|c|c|c|c|c|c|}
\hline $\begin{array}{l}\text { Site } \\
\text { no. }\end{array}$ & Site name & Latitude DD & Longitude DD & $\begin{array}{c}\text { No. of } \\
\text { samples }\end{array}$ & $\begin{array}{c}\text { Period of } \\
\text { record }\end{array}$ \\
\hline \multicolumn{6}{|c|}{ Chaco Wash } \\
\hline $1343 *$ & Chaco Wash at Chaco Canyon National Monument, NM & 36.0287 & 107.9184 & 648 & $1976-1983$ \\
\hline $1345^{*}$ & Chaco Wash nr PB at Bridge at Chaco Canyon Natl Mon, NM & 36.0540 & 107.9651 & 57 & $1981-1983$ \\
\hline 2167 & 20N.09W.03.332 Chaco R 8 Mi SE Vis Ctr Chaco Mon & 35.9892 & 107.7842 & 1 & 1976 \\
\hline 2178 & 22N.13W.26.2314 Chaco R at Hwy 371 Bridge & 36.1139 & 108.1917 & 2 & 1981-1982 \\
\hline \multicolumn{6}{|c|}{ Contributing Washes } \\
\hline \multicolumn{6}{|c|}{$\begin{aligned} \text { Escavada Wash } \\
\end{aligned}$} \\
\hline 2176 & 22N.11W.25.433 Escavada Wash at Hwy 56 Br., NM & 36.1039 & 107.9562 & 10 & 1977-1981 \\
\hline \multicolumn{6}{|c|}{ Fajada Wash } \\
\hline 2169 & 21N.09W.17.233 Gallo Wash at Dike nr Chaco Natl Mon, NM & 36.0522 & 107.8126 & 1 & 1978 \\
\hline \multicolumn{6}{|c|}{ Kim-me-ni-oli Wash } \\
\hline $1346^{*}$ & Kim-me-ni-oli Wash nr Lake Valley, NM & 35.9792 & 108.1381 & 21 & 1978-1983 \\
\hline 2090 & Kim-me-ni-oli Wash nr Crownpoint, NM & 35.8486 & 108.0606 & 15 & $1978-1983$ \\
\hline 2164 & 18N.11W.21.111 KMNO Wash at Hwy 57 Crossing & 35.7834 & 108.0190 & 1 & 1982 \\
\hline 2166 & 20N.12W.33.331 KMNO Wash 6 Mi E Milk Lk, NM & 35.9178 & 108.1267 & 2 & $1981-1982$ \\
\hline 2168 & 21N.12W.31.414 KMNO Wash at Dike & 36.0064 & 108.1531 & 2 & 1981-1982 \\
\hline 2170 & 21N.12W.07.222 KMNO Wash 1.1 Mi S L.V. School, NM & 36.0756 & 108.1501 & 2 & 1981-1982 \\
\hline 2175 & 22N.12W.31.4143 KMNO Wash above Juan Lake & 36.0942 & 108.1548 & 1 & 1981 \\
\hline
\end{tabular}

were not available from other washes and arroyos in CHCU. No water-quality data have been collected in the park since 1983. The relative temporal distribution of water samples from sites with available data and the types of analyses conducted on samples are illustrated in figure 11. The number of analyses by the three stream groupings for individual field properties and constituents is provided in table 16. Between January 1976 and October 1983, 715 samples from six sites were collected from Chaco Wash; eight of these samples were collected outside the park boundary. Ninety-one percent of the samples were collected from Chaco Wash at Chaco National Monument (site 1343, fig. 10; table 15). Twenty-nine samples (from four sites) were collected from the contributing washes, including 10 samples from Escavada Wash between February 1977 and July 1981, 7 samples from Fajada Wash from June 1981 to October 1983, and 12 samples from Gallo Wash from January 1979 through October 1983. Kim-me-ni-oli Wash was sampled 53 times at eight sites from March 1978 to October 1983.
Noticeable data gaps for $\mathrm{CHCU}$ are the lack of recent data for any of the surface-water sites in or near the park. Though a large number (more than 500) of streamflow measurements, water-temperature measurements, and suspended sediment results are available from Chaco Wash, most other field properties and constituents were measured or analyzed much less frequently.

\section{Characterization of Water Quality}

The historical water-quality data available for the three site grouping were assessed according to State standards associated with designated uses assigned by the State of New Mexico, including aquatic-life, warm-water fishery, and livestock-watering standards. Because these historical data (collected between 1976 and 1983) are the only water-quality data available for this area, these data are compared to current water-quality standards even though most of the current (2007) State water-quality standards were not applicable when these 


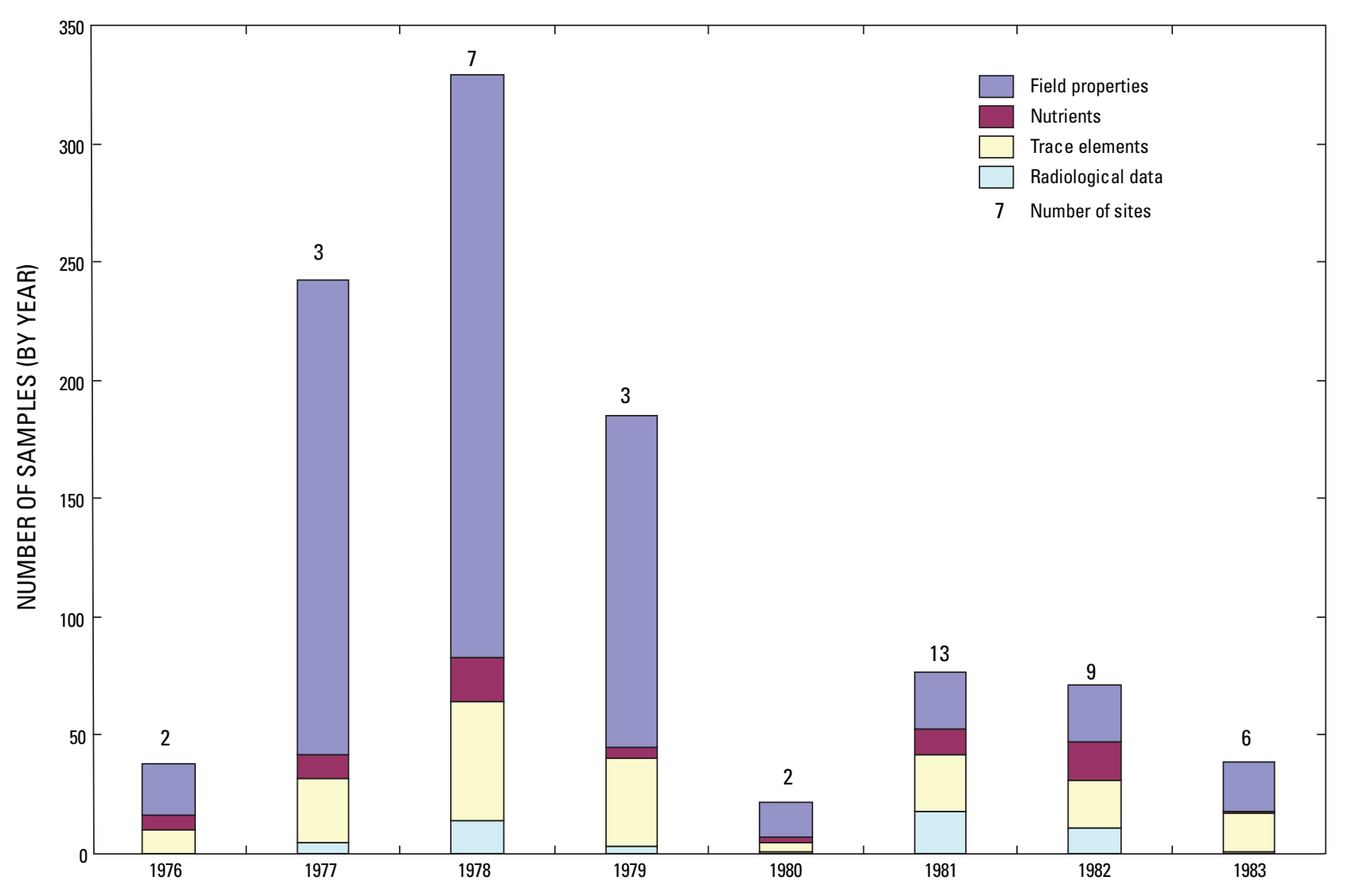

Figure 11. Total number of stream samples (and sites) collected for field properties, nutrients, trace elements, and radiological constituents, Chaco Culture National Historical Park, New Mexico, 1976 to 1983.

samples were collected. Additionally, no fish are currently present in $\mathrm{CHCU}$, which limits the interpretation of historical values that exceed aquatic-life and warm-water fishery standards (Stephen Monroe, National Park Service, written commun., 2007).

\section{Field Properties}

Acid neutralizing capacity, DO, pH, SC, and turbidity were measured in all three site groups (except turbidity, which was not measured in Kim-me-ni-oli Wash) between one and 126 times at 45 sites (table 16). Streamflow and water temperature were measured frequently (533 to 699 times) in Chaco Wash and the Chaco River and 14 to 47 times in the contributing washes (Escavada, Fajada, and Gallo Washes) and Kim-me-ni-oli Wash.

One $\mathrm{pH}$ measurement of $6.3 \mathrm{SU}$ (out of 124 measurements) from Chaco Wash was below the warm-water fisheries standard of 6.6 SU. Measurements of $\mathrm{pH}$ exceeding the aquatic warm-water fisheries standard of $9 \mathrm{SU}$ were observed in 13 of 42 measurements (from six sites) made in Kim-me-nioli Wash and ranged from 9.1 to $9.5 \mathrm{SU}$. Elevated $\mathrm{pH}$ values, which can harm fish, could be the result of weathering of the typically alkaline Menefee Shale and Cliff House Sandstone formations exposed in Chaco Wash and the Chaco River, Kim-me-ni-oli Wash, and contributing arroyos in and upstream from the park.

Specific-conductance measurements (maximum values ranged from 3,250 to $5,000 \mu \mathrm{S} / \mathrm{cm}$ ) were elevated in all three water groups. Elevated specific conductance (salinity) reflects the concentration of major dissolved ions and can influence sensitive aquatic biota. Elevated salinity could be a result of dissolution of mineral salts from soil and bedrock and leaching of mineral salts from upstream mining activities.

Turbidity values (values ranged from 2,200 to 36,000 NTU) were elevated in measurements made in Chaco Wash (three measurements) and Escavada Wash (one measurement). Elevated turbidity values could be a result of stream-channel downcutting and erosion and other sources that can result in increased suspended solids (for example, silts, clays, and sewage). Park personnel have identified erosion as a water-quality concern for $\mathrm{CHCU}$, and the potential for excess nutrients and erosion from trampled riparian areas and washes exists in the watershed from grazing activities occurring outside fenced park boundaries (Thomas and others, 2006). Few turbidity and DO measurements are available to determine if these may be a chronic water-quality concern for the park. 
Table 16. Statistical summary of water-quality data and exceedances of water-quality standards at selected stream-sampling sites located in, upstream from, and at the downstream boundary of Chaco Culture National Historical Park, New Mexico, 1976 to 1983. Conti

[AL, aquatic life; dep, dependent; Contrib., contributing; EPA RC III, U.S. Environmental Protection Agency National Recommended Nutrient Criteria for Ecoregion III; fil, filtered; H, high (maximum) standard; L, low (minimum) standard; LW, livestock watering; mg/L, milligrams per liter; N, nitrogen; NAWQ, National Ambient Water Quality; NMWQCC, New Mexico Water Quality Control Commission (Standard); No., number; NTU, nephelometric turbidity units; P, phosphorus; pCi/L, picocuries per liter; POR, period of record; R., river; rec, recoverable; temp, temperature; TVS, table value standard; TVS 100, table value standard computed at a hardness of $100 \mathrm{mg} / \mathrm{L}$ (provided as a baseline for comparison, site-specific TVS used for exceedance analysis); unfil, unfiltered; unsp, unspeciated; W., wash; WF, warm-water fishery; $\mu \mathrm{S} / \mathrm{cm}$, microsiemens per centimeter; $\mu \mathrm{g} / \mathrm{L}$, micrograms per liter; <, less than; --, not available or not computed; bold type indicates exceedance]

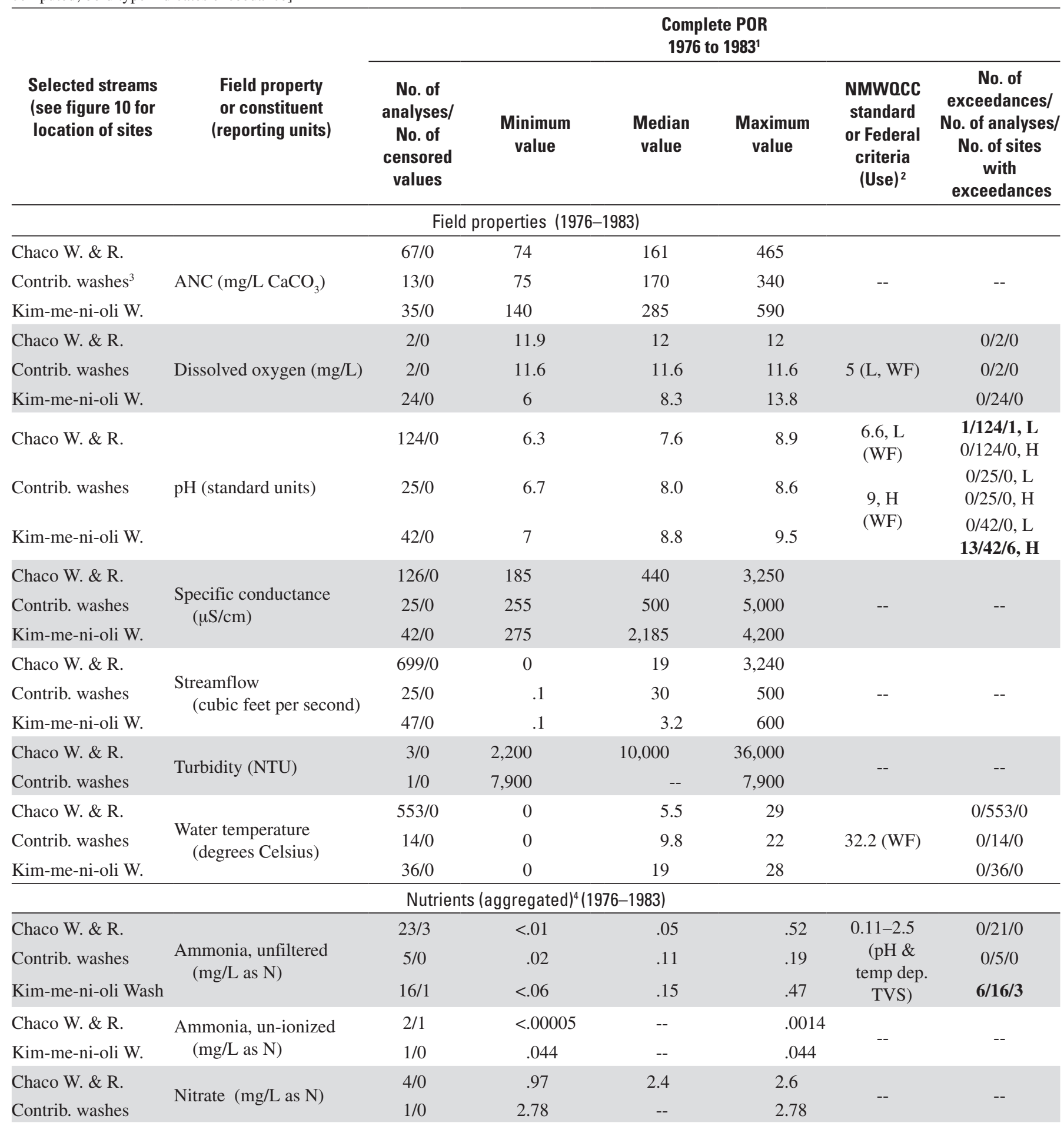


Table 16. Statistical summary of water-quality data and exceedances of water-quality standards at selected stream-sampling sites located in, upstream from, and at the downstream boundary of Chaco Culture National Historical Park, New Mexico, 1976 to 1983. Continued

[AL, aquatic life; dep, dependent; Contrib., contributing; EPA RC III, U.S. Environmental Protection Agency National Recommended Nutrient Criteria for Ecoregion III; fil, filtered; H, high (maximum) standard; L, low (minimum) standard; LW, livestock watering; mg/L, milligrams per liter; N, nitrogen; NAWQ, National Ambient Water Quality; NMWQCC, New Mexico Water Quality Control Commission (Standard); No., number; NTU, nephelometric turbidity units; P, phosphorus; pCi/L, picocuries per liter; POR, period of record; R., river; rec, recoverable; temp, temperature; TVS, table value standard; TVS 100, table value standard computed at a hardness of $100 \mathrm{mg} / \mathrm{L}$ (provided as a baseline for comparison, site-specific TVS used for exceedance analysis); unfil, unfiltered; unsp, unspeciated; W., wash; WF, warm-water fishery; $\mu \mathrm{S} / \mathrm{cm}$, microsiemens per centimeter; $\mu \mathrm{g} / \mathrm{L}$, micrograms per liter; <, less than; --, not available or not computed; bold type indicates exceedance]

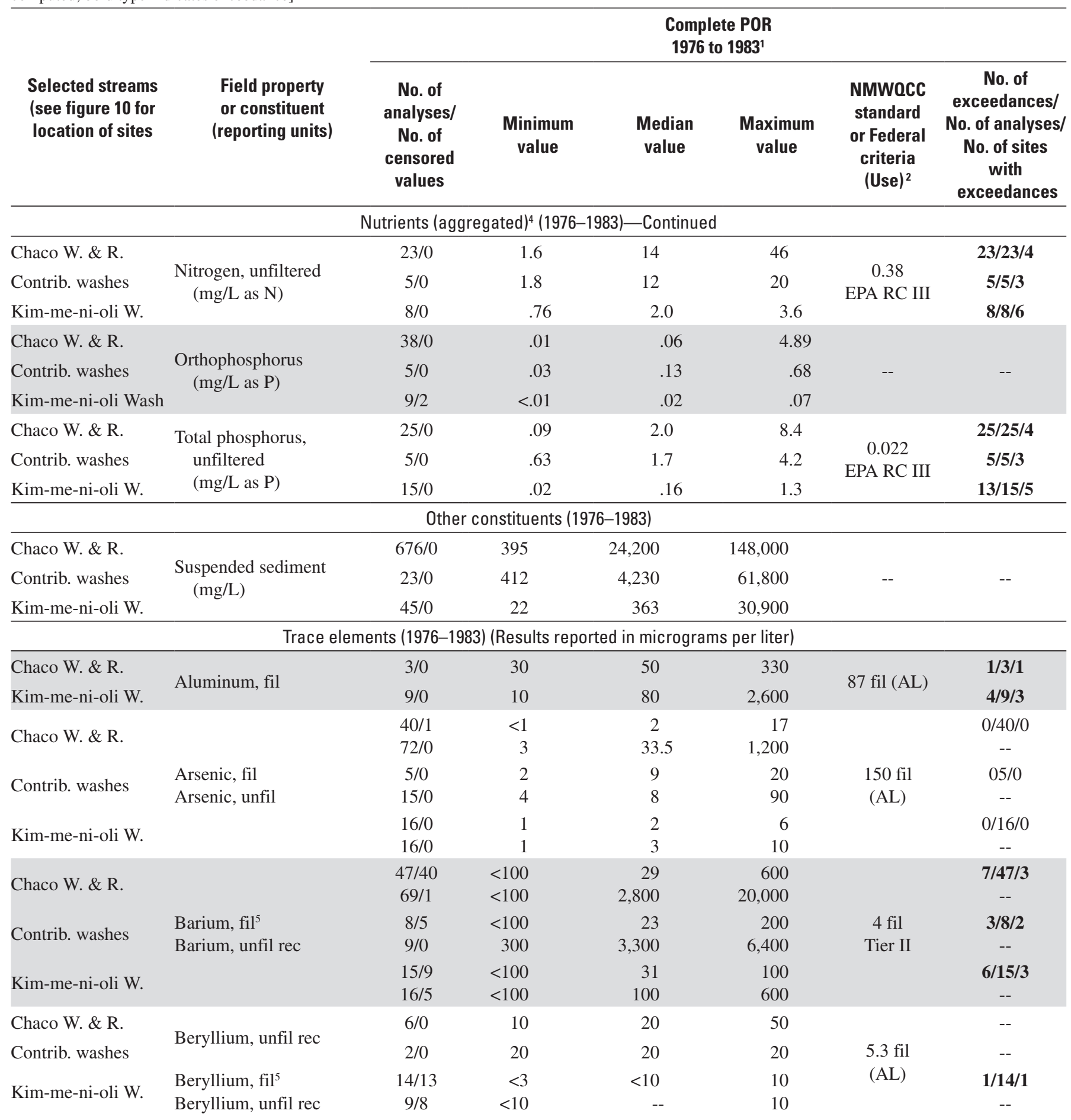


Table 16. Statistical summary of water-quality data and exceedances of water-quality standards at selected stream-sampling sites located in, upstream from, and at the downstream boundary of Chaco Culture National Historical Park, New Mexico, 1976 to 1983. Continued

[AL, aquatic life; dep, dependent; Contrib., contributing; EPA RC III, U.S. Environmental Protection Agency National Recommended Nutrient Criteria for Ecoregion III; fil, filtered; H, high (maximum) standard; L, low (minimum) standard; LW, livestock watering; mg/L, milligrams per liter; N, nitrogen; NAWQ, National Ambient Water Quality; NMWQCC, New Mexico Water Quality Control Commission (Standard); No., number; NTU, nephelometric turbidity units; P, phosphorus; pCi/L, picocuries per liter; POR, period of record; R., river; rec, recoverable; temp, temperature; TVS, table value standard; TVS 100, table value standard computed at a hardness of $100 \mathrm{mg} / \mathrm{L}$ (provided as a baseline for comparison, site-specific TVS used for exceedance analysis); unfil, unfiltered; unsp, unspeciated; W., wash; WF, warm-water fishery; $\mu \mathrm{S} / \mathrm{cm}$, microsiemens per centimeter; $\mu \mathrm{g} / \mathrm{L}$, micrograms per liter; <, less than; --, not available or not computed; bold type indicates exceedance]

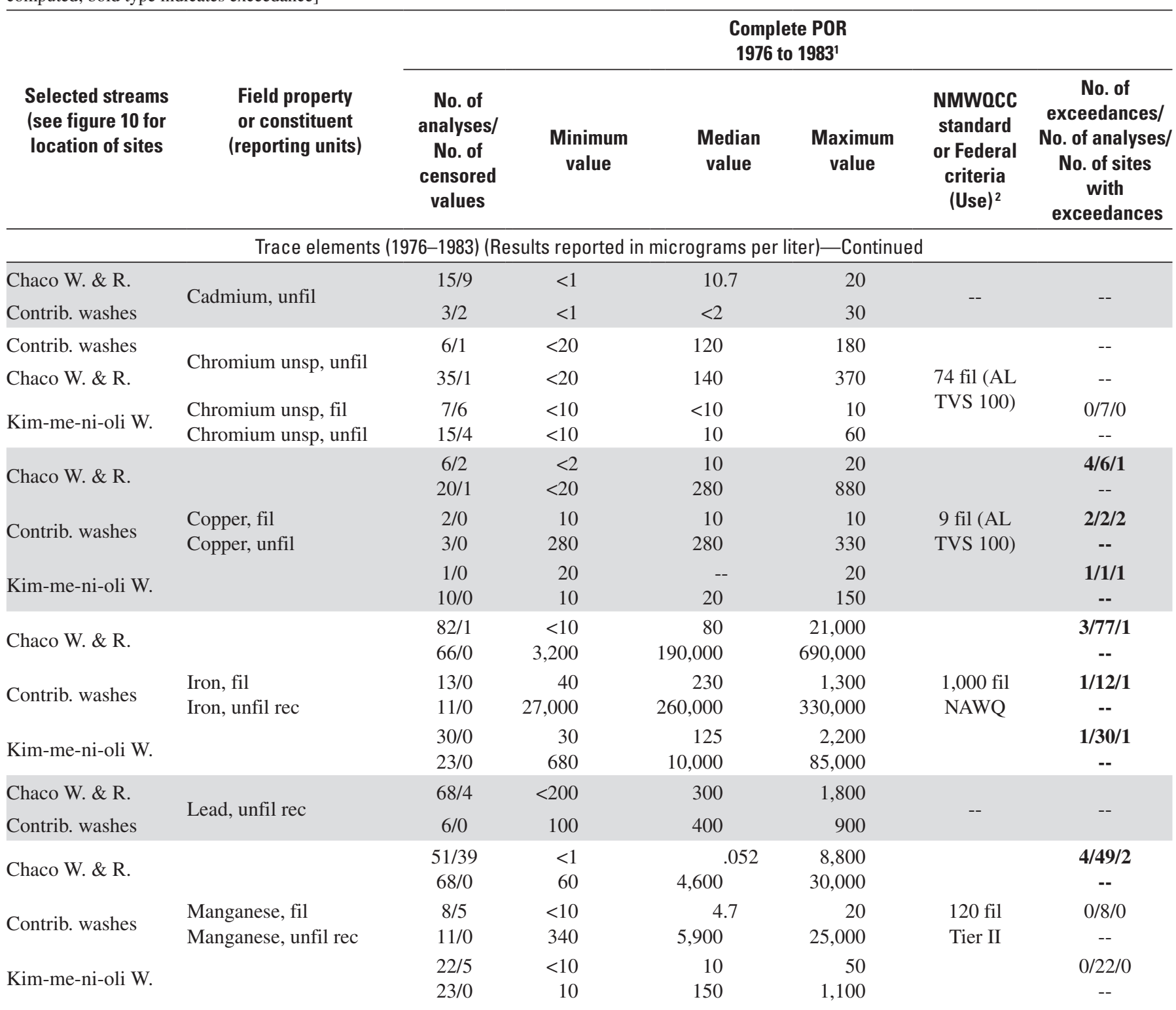


Table 16. Statistical summary of water-quality data and exceedances of water-quality standards at selected stream-sampling sites located in, upstream from, and at the downstream boundary of Chaco Culture National Historical Park, New Mexico, 1976 to 1983. Continued

[AL, aquatic life; dep, dependent; Contrib., contributing; EPA RC III, U.S. Environmental Protection Agency National Recommended Nutrient Criteria for Ecoregion III; fil, filtered; H, high (maximum) standard; L, low (minimum) standard; LW, livestock watering; mg/L, milligrams per liter; N, nitrogen; NAWQ, National Ambient Water Quality; NMWQCC, New Mexico Water Quality Control Commission (Standard); No., number; NTU, nephelometric turbidity units; P, phosphorus; pCi/L, picocuries per liter; POR, period of record; R., river; rec, recoverable; temp, temperature; TVS, table value standard; TVS 100, table value standard computed at a hardness of $100 \mathrm{mg} / \mathrm{L}$ (provided as a baseline for comparison, site-specific TVS used for exceedance analysis); unfil, unfiltered; unsp, unspeciated; W., wash; WF, warm-water fishery; $\mu \mathrm{S} / \mathrm{cm}$, microsiemens per centimeter; $\mu \mathrm{g} / \mathrm{L}$, micrograms per liter; <, less than; --, not available or not computed; bold type indicates exceedance]

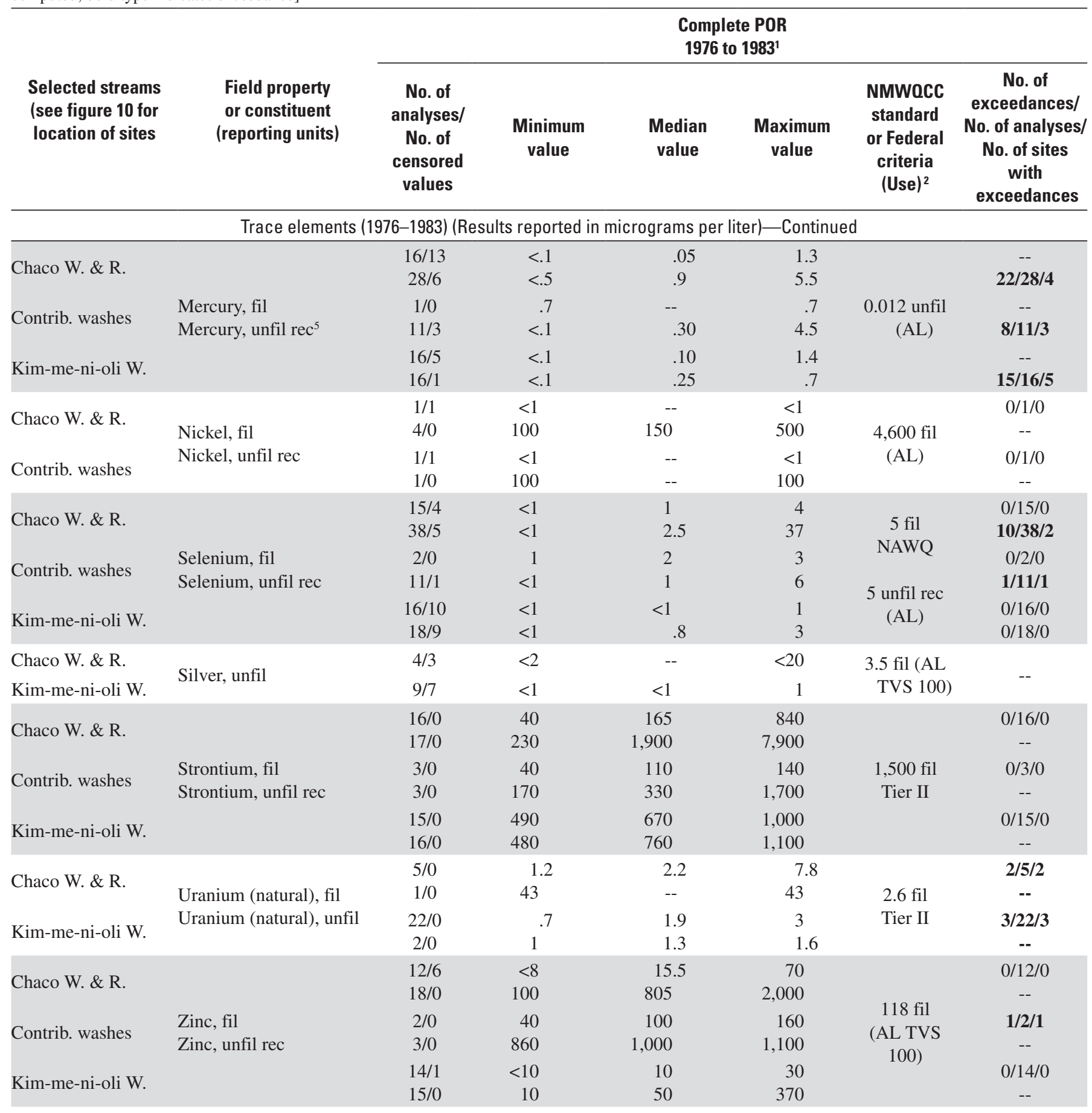


Table 16. Statistical summary of water-quality data and exceedances of water-quality standards at selected stream-sampling sites located in, upstream from, and at the downstream boundary of Chaco Culture National Historical Park, New Mexico, 1976 to 1983._ Continued

[AL, aquatic life; dep, dependent; Contrib., contributing; EPA RC III, U.S. Environmental Protection Agency National Recommended Nutrient Criteria for Ecoregion III; fil, filtered; H, high (maximum) standard; L, low (minimum) standard; LW, livestock watering; mg/L, milligrams per liter; N, nitrogen; NAWQ, National Ambient Water Quality; NMWQCC, New Mexico Water Quality Control Commission (Standard); No., number; NTU, nephelometric turbidity units; P, phosphorus; pCi/L, picocuries per liter; POR, period of record; R., river; rec, recoverable; temp, temperature; TVS, table value standard; TVS 100, table value standard computed at a hardness of $100 \mathrm{mg} / \mathrm{L}$ (provided as a baseline for comparison, site-specific TVS used for exceedance analysis); unfil, unfiltered; unsp, unspeciated; W., wash; WF, warm-water fishery; $\mu \mathrm{S} / \mathrm{cm}$, microsiemens per centimeter; $\mu \mathrm{g} / \mathrm{L}$, micrograms per liter; <, less than; --, not available or not computed; bold type indicates exceedance]

\begin{tabular}{|c|c|c|c|c|c|c|c|}
\hline \multirow[b]{2}{*}{$\begin{array}{l}\text { Selected streams } \\
\text { (see figure } 10 \text { for } \\
\text { location of sites }\end{array}$} & \multirow[b]{2}{*}{$\begin{array}{l}\text { Field property } \\
\text { or constituent } \\
\text { (reporting units) }\end{array}$} & \multicolumn{6}{|c|}{$\begin{array}{c}\text { Complete POR } \\
1976 \text { to } 1983^{1}\end{array}$} \\
\hline & & $\begin{array}{c}\text { No. of } \\
\text { analyses/ } \\
\text { No. of } \\
\text { censored } \\
\text { values }\end{array}$ & $\begin{array}{l}\text { Minimum } \\
\text { value }\end{array}$ & $\begin{array}{l}\text { Median } \\
\text { value }\end{array}$ & $\begin{array}{l}\text { Maximum } \\
\text { value }\end{array}$ & $\begin{array}{l}\text { NMWOCC } \\
\text { standard } \\
\text { or Federal } \\
\text { criteria } \\
\text { (Use) }{ }^{2}\end{array}$ & $\begin{array}{c}\text { No. of } \\
\text { exceedances/ } \\
\text { No. of analyses/ } \\
\text { No. of sites } \\
\text { with } \\
\text { exceedances }\end{array}$ \\
\hline Chaco W. \& R. & Gross alpha radioactivity, & $5 / 2$ & $<2.2$ & 4.1 & 35 & \multirow[b]{2}{*}{$15(\mathrm{LW})$} & $1 / 5 / 1$ \\
\hline Kim-me-ni-oli W. & $\begin{array}{l}\text { natural uranium curve, } \\
\text { fil }(\mathrm{pCi} / \mathrm{L})\end{array}$ & $9 / 6$ & $<2.7$ & 1.1 & 31 & & $2 / 9 / 2$ \\
\hline Chaco W. \& R. & $\begin{array}{l}\text { Gross alpha radioactivity, } \\
\text { natural uranium curve, } \\
\text { fil }(\mu \mathrm{g} / \mathrm{L})\end{array}$ & $9 / 4$ & $<3.2$ & 6.0 & $<51$ & -- & -- \\
\hline Kim-me-ni-oli W. & Radium-228 (pCi/L) & $4 / 4$ & $<2.11$ & -- & $<3.50$ & $30(\mathrm{LW})$ & $0 / 4 / 0$ \\
\hline
\end{tabular}

${ }^{1}$ Period of record reflects full range evaluated for all relevant sites within this time period; some sites or constituents may not have had data available for the entire record. All available data considered; POR varies with constituent and site.

${ }^{2}$ State standards and designated beneficial uses from the State of New Mexico Water Quality Control Commission (2002). Selected Federal criteria are used when State standards are not established, including the USEPA National Recommended Nutrient Criteria for Ecoregions II and III (U.S. Environmental Protection Agency, 2002), the National Ambient Water Quality criteria (NAWQ), or the secondary chronic Tier II values (Suter and Tsao, 1996).

${ }^{3}$ Includes all available data from Escavada, Fajada, and Gallo Washes.

${ }^{4}$ Aggregated nutrients based on Mueller and others (1995); where sample fraction not stated, aggregation includes both filtered and unfiltered concentrations. Zero values were excluded unless converted to a value of less than the censoring level.

${ }^{5}$ Most or all the censoring levels for this constituent exceed the NMWQCC or Federal criteria, and exceedances could be higher because the censoring level is larger than the water-quality standard. 


\section{Major lons}

Chaco Wash, Chaco River, and contributing washes (Escavada, Fajada, and Gallo Washes) are predominantly a sodium bicarbonate water type, and Kim-me-ni-oli Wash is predominantly a sodium sulfate type water (fig. 12). A few analyses of samples for major ions indicate high concentrations of chloride (Kim-me-ni-oli Wash) or calcium (Chaco Wash). Generally the waters are of similar chemical composition upstream and through Chaco Wash and the Chaco River. Kim-me-ni-oli Wash appears to be controlled by different source rock geochemistry that is higher in sodium and sulfate, which is a reflection of the dominant Menefee Formation in this drainage.

\section{Nutrients}

Samples analyzed for nutrients, including ammonia (unfiltered and un-ionized), nitrate (unfiltered and filtered), total nitrogen (unfiltered), orthophosphorus (unfiltered and filtered), and total phosphorus (unfiltered), were collected between one and 38 times from 29 sites in Chaco Wash and the Chaco River, the contributing washes (Escavada, Fajada, and Gallo Washes), and Kim-me-ni-oli Wash. Un-ionized ammonia and nitrate were analyzed from samples only one to four times.

Six analyses of samples (out of 16 samples) from Kim-me-ni-oli Wash exceeded the New Mexico chronic warm-water TVS for unfiltered ammonia (table 16), based on available temperature and $\mathrm{pH}$ data, and were generally associated with higher water temperatures and $\mathrm{pH}$ values.

The USEPA-recommended nutrient criterion for total nitrogen is $0.38 \mathrm{mg} / \mathrm{L}$ in rivers and streams (U.S. Environmental Protection Agency, 2002). All analyses of 36 samples from the three water groups analyzed for total nitrogen (unfiltered) exceeded the recommended criterion, and concentrations ranged from 0.76 to $46 \mathrm{mg} / \mathrm{L}$. Median total nitrogen concentrations from Chaco Wash and the Chaco River were $14 \mathrm{mg} / \mathrm{L}$ and from the contributing washes $12 \mathrm{mg} / \mathrm{L}$, indicating elevated nitrogen in the waters contributing to the Chaco River. The highest overall concentrations (15 samples exceeded $10 \mathrm{mg} / \mathrm{L}$ ) were analyzed in samples from Chaco Wash, Escavada Wash, and Fajada Wash; 12 of these were from Chaco Wash. The three highest values of 34,43 , and $46 \mathrm{mg} / \mathrm{L}$ were each measured in Chaco

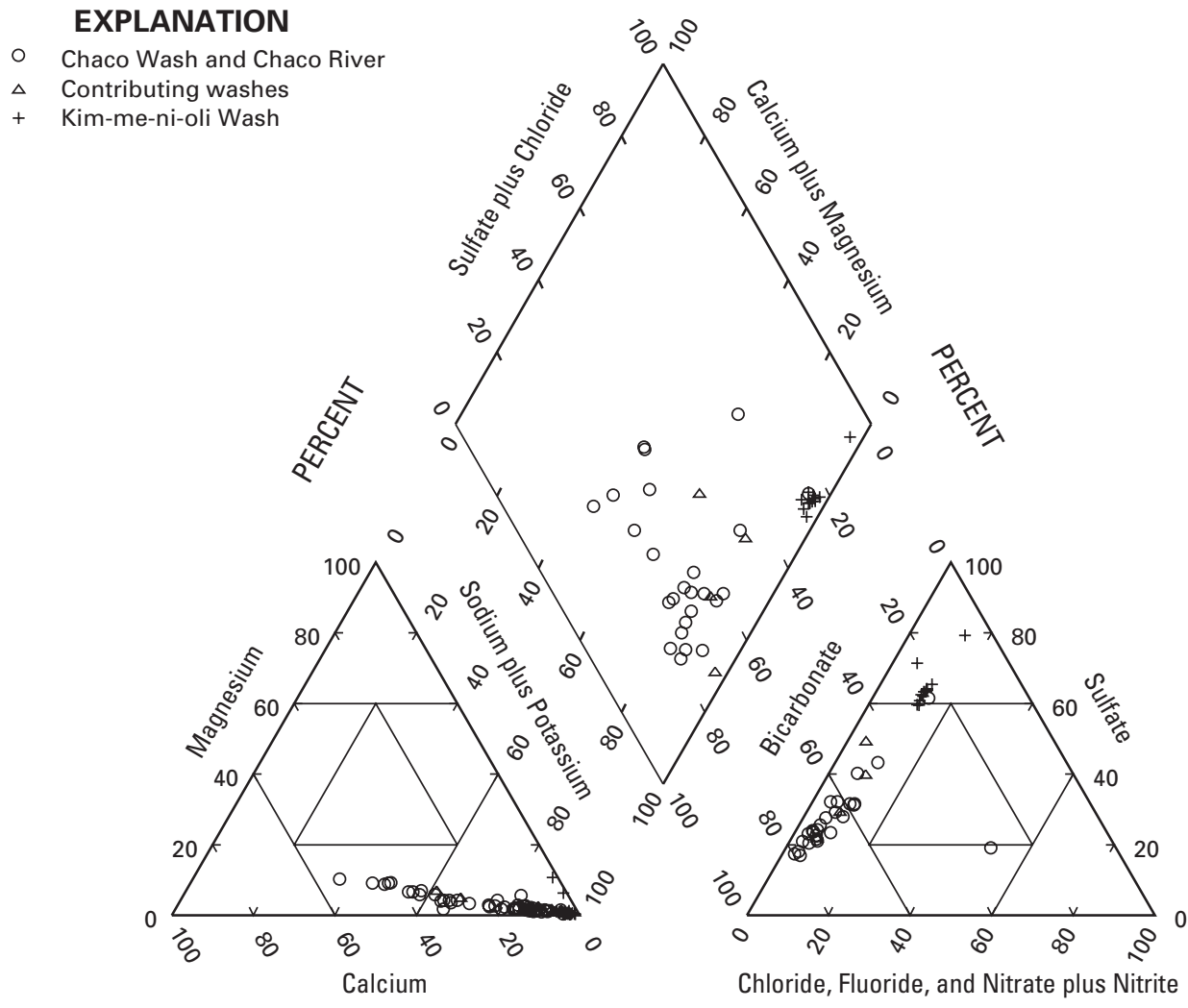

PERCENTAGE OF TOTAL MILLIEQUIVALENTS PER LITER

Figure 12. Water types of contributing washes (Escavada, Fajada, and Gallo Washes), Chaco Wash and the Chaco River, and Kim-me-ni-oli Wash, Chaco Culture National Historical Park, New Mexico, 1976 to 1983. 
Wash; two of these values were associated with suspendedsediment concentrations greater than 23,000 mg/L. Due to the historical nature of these data and lack of corresponding quality-control data, these unusually high values could be the result of laboratory error or reporting error (though they are consistently high), or they may represent actual high concentrations of nitrogen.

While the State of New Mexico has not established instream standards for total phosphorus, the USEPA has recommended total phosphorus concentrations be less than $0.022 \mathrm{mg} / \mathrm{L}$ in rivers and streams for controlling eutrophication in aggregate Ecoregion III, which includes CHCU (U.S. Environmental Protection Agency, 2002). Concentrations of 43 analyses of samples (out of 45 samples from 12 sites) for total phosphorus (unfiltered) exceeded the recommended total phosphorus criterion for rivers and streams, and these elevated concentrations ranged from 0.07 to $8.4 \mathrm{mg} / \mathrm{L}$. The highest overall concentrations (16 samples equal to or greater than $2 \mathrm{mg} / \mathrm{L}$ ) were measured in Chaco Wash and Fajada Wash and were associated with elevated suspended-sediment concentrations (greater than $10,900 \mathrm{mg} / \mathrm{L}$ ).

Elevated concentrations of nutrients could be the result of grazing activities resulting in erosion and runoff in the riparian areas, atmospheric nitrogen deposition (from burning of fossil fuels), or natural weathering of nitrogen-rich or phosphorusrich bedrock (Holloway and Dahlgren, 2002; Gardner, 1990; Chapman, 1998; Paerl, 1997). Excessive levels of nutrients may cause eutrophication, an unhealthy increase in the growth of phytoplankton that can lead to reduced water clarity, low dissolved oxygen, changes in aquatic species composition, and potentially harmful algal blooms (U.S. Environmental Protection Agency, 2001; Galloway and others, 2003).

\section{Other Constituents}

Suspended sediment concentrations (values ranged from 22 to 148,000 $\mathrm{mg} / \mathrm{L}$ ) were elevated in analyses of samples from Chaco Wash (676 analyses) with a median of 24,200 mg/L. Escavada Wash had the highest median suspended sediment value $(43,550 \mathrm{mg} / \mathrm{L})$ while Gallo Wash had the lowest median value $(2,440 \mathrm{mg} / \mathrm{L})$ of the three contributing washes. Concentrations for suspended sediment analyses from Kim-me-ni-oli Wash were all below $5,000 \mathrm{mg} / \mathrm{L}$ for the 36 samples collected after April 1981 while the eight of the 10 samples collected before this time were greater than $5,000 \mathrm{mg} / \mathrm{L}$ (6,630 to $30,900 \mathrm{mg} / \mathrm{L})$. Elevated suspended sediment values could be a result of stream-channel downcutting and erosion and other sources that can result in increased suspended materials (for example, silts and clays). Park personnel have identified erosion as a water-quality concern for $\mathrm{CHCU}$, and the potential for erosion from trampled riparian areas and washes exists in the watershed from grazing activities occurring outside fenced park boundaries (Thomas and others, 2006).

\section{Trace Elements}

Analyses of samples from Chaco Wash and Kim-me-nioli Wash for concentrations of (filtered) aluminum exceeded the New Mexico chronic aquatic-life standard of $87 \mu \mathrm{g} / \mathrm{L}$ one and four times, respectively, and concentrations ranged from 90 to $2,600 \mu \mathrm{g} / \mathrm{L}$ (table 16). One value of 2,600 $\mu \mathrm{g} / \mathrm{L}$ measured in a June 1982 sample from Kim-me-ni-oli Wash exceeded the acute standard of $750 \mu \mathrm{g} / \mathrm{L}$. Filtered aluminum reported in high concentrations could be a result of particulates passing through the filter membrane and may not be a reflection of actual dissolved aluminum in the aquatic system (Hem, 1989).

One filtered beryllium concentration of $10 \mu \mathrm{g} / \mathrm{L}$, from 14 samples collected in Kim-me-ni-oli Wash, exceeded the New Mexico chronic aquatic-life standard of $5.3 \mu \mathrm{g} / \mathrm{L}$. All other values for beryllium were below the censoring levels, which ranged from less than 3 to less than $10 \mu \mathrm{g} / \mathrm{L}$, some of which are higher than the standard.

Seven filtered copper concentrations, four from samples collected in Chaco Wash and one each from samples collected in Fajada, Escavada, and Kim-me-ni-oli Wash, exceeded the New Mexico chronic aquatic-life standard of $9 \mu \mathrm{g} / \mathrm{L}$, based on a TVS of $100 \mathrm{mg} / \mathrm{L}$ hardness, and these elevated concentrations ranged from 10 to $20 \mu \mathrm{g} / \mathrm{L}$. Unfiltered copper concentrations were as high as $880 \mu \mathrm{g} / \mathrm{L}$ in samples from Chaco Wash.

Concentrations of unfiltered mercury exceeded the New Mexico chronic aquatic-life standard of $0.012 \mu \mathrm{g} / \mathrm{L}$ a total of 45 times, and concentrations ranged from less than 0.1 to $5.5 \mu \mathrm{g} / \mathrm{L}$, including 2 exceedances each from analyses of samples collected from Fajada and Escavada Wash, 4 from Gallo Wash, 15 from Kim-me-ni-oli Wash, and 22 from Chaco Wash and Chaco River. The remaining mercury results were below their censoring levels, which ranged from less than 0.1 to less than $0.5 \mu \mathrm{g} / \mathrm{L}$ and which are higher than the standard. Awareness of the bioaccumulative effects of mercury in the environment occurred after these data were collected; this awareness prompted the development of new analytical methods to detect mercury at lower concentrations (Microbac Laboratories, Inc., 2005) and resulted in the current Federal criterion and State aquatic-life standards. These elevated values maybe a result of the surrounding geology or from atmospheric deposition.

Water concentrations exceeded the chronic aquatic-life standard of $5 \mu \mathrm{g} / \mathrm{L}$ for unfiltered recoverable selenium 11 times, and concentrations ranged from 6 to $37 \mu \mathrm{g} / \mathrm{L}$. Ten of these elevated concentrations were from analyses of samples collected from Chaco Wash, and one was from Fajada Wash. Potential selenium sources include the local geology (Menefee Formation and Lewis Shale), leaching from seleniferous soils in the park's drainage area, and perhaps atmospherically deposited coal-fired powerplant ash (Bureau of Indian Affairs, 2007).

For detected trace elements without New Mexico numeric aquatic-life standards or TVS, the concentrations were compared to the chronic NAWQ criteria or Tier II values presented by Suter and Tsao (1996) as toxicological benchmarks useful for screening constituents for aquatic 
ecological effects. These Federal benchmarks were exceeded in analyses of samples for filtered barium (16 times), iron (5 times), manganese (4 times), and uranium (5 times) and were identified as constituents of potential ecological concern (table 16). Filtered iron reported in high concentrations could be a result of particulates passing through the filter membrane and may not be a reflection of actual dissolved iron in the aquatic system (Hem, 1989). The filtered strontium values did not exceed the recommended Tier II criterion.

Unfiltered iron (concentrations ranging from 680 to $690,000 \mu \mathrm{g} / \mathrm{L}$ ) and unfiltered strontium (concentrations ranging from 170 to $7,900 \mu \mathrm{g} / \mathrm{L}$ ) were measured at elevated levels in analyses of samples from all three water groups; however, no State aquatic or human-health standards exist for these constituents (table 16). Iron concentrations increased as suspended-sediment concentrations increased, indicating elevated iron is associated with sediment transport occurring in the drainages. Concentrations of filtered strontium ranged from 40 to $1,000 \mu \mathrm{g} / \mathrm{L}$ in all three water groups and are below the 1,500- $\mu \mathrm{g} / \mathrm{L}$ Tier II criterion. The median value for filtered (dissolved) strontium in major North American rivers was reported to be $60 \mu \mathrm{g} / \mathrm{L}$ by Durum and Haffty (1961), indicating generally elevated concentrations. Potential natural weathering sources for strontium include the minerals strontianite (strontium carbonate) and celestite (strontium sulfate), which could be present in the Menefee Formation and Lewis Shale in the park (Hem, 1989).

\section{Radiological Constituents}

Gross alpha radioactivity was measured in 14 samples; values from one of five analyses of samples from Chaco Wash and two of nine analyses of samples from Kim-me-ni-oli Wash exceeded the 15 picocuries per liter ( $\mathrm{pCi} / \mathrm{L}$ ) standard for livestock watering (table 16). Values exceeding this standard in samples from these washes ranged from 29 to $35 \mathrm{pCi} / \mathrm{L}$. These elevated values may well be a result of naturally occurring radionuclides from the surrounding geology or from atmospheric deposition.

\section{Summary of Surface-Water Characterization and Considerations for Monitoring}

All available water-quality data evaluated for CHCU were collected between 1976 and 1983, which limits interpretation and limits understanding of current water-quality conditions and potential effects. Information on human activities on land surrounding the park prior to and during the sample-collection activities also is sparse, further limiting the ability to interpret these historical data. The contributing washes offered the smallest number of sample results for evaluation, and any differences in water quality related to differences in natural factors or to land-use activities in the three washes could not be ascertained from this small dataset.

Data from Chaco Wash generally indicates higher concentrations of nutrients (unfiltered nitrogen, orthophosphorus, and unfiltered phosphorus) and trace elements. More exceedances of New Mexico water-quality standards were identified in Chaco Wash than in the other evaluated waters in $\mathrm{CHCU}$, which may be a reflection of natural influences from the Lewis Shale and Menefee Formation predominant in the Chaco Wash drainage area or of the current land-use activities. Data from Chaco and Kimme-ni-oli Wash indicate elevated gross alpha radioactivity, which could have resulted from weathering of radioactive minerals from source bedrock or from mining occurring in the contributing area. Concentrations of unfiltered nitrogen and phosphorus were elevated in analyses of samples from all waters evaluated in $\mathrm{CHCU}$ and could be related to atmospheric deposition (nitrogen), bedrock weathering (primarily phosphorus but possibly nitrogen), and upland and semiriparian zone grazing activities.

Historical concentrations of trace elements are elevated for several constituents in one or more analyses of samples from park waters and exceed State criteria for aquatic life for filtered aluminum, beryllium, copper, and zinc and for unfiltered mercury and selenium. All analyses of samples from waters in CHCU had multiple exceedances of the chronic aquatic-life standard for unfiltered mercury. Concentrations of unfiltered selenium also frequently exceeded the State standard in analyses of samples from the contributing washes and Chaco Wash. In addition to the constituent concentrations that exceeded the State standards, concentrations of filtered barium, iron, manganese, and uranium exceeded selected ecological benchmarks and may warrant inclusion in future monitoring efforts. Uranium mining and coalbed methane exploration are actively occurring in the San Juan Basin and in proximity to the park, which could expose trace elements (in mining wastes) to weathering and dissolution. High concentrations of selected trace elements also could be the result of atmospheric deposition or natural bedrock and soil weathering processes, which can be magnified by agricultural irrigation of mineralized soils.

For future water-quality monitoring efforts, it would be useful to include analyses of samples for nutrients, trace elements, and radiological constituents to evaluate if concentrations of these water-quality constituents identified as elevated in the historical data set are currently measurable at levels of ecological concern and to identify if surrounding land-use activities could be affecting park water quality.

\section{Glen Canyon National Recreation Area, Arizona and Utah}

Glen Canyon National Recreation Area (GLCA), which covers more than 1.2 million acres, extends from southeastern Utah more than $180 \mathrm{mi}$ into northeastern Arizona. The main feature of the park, Lake Powell, covers about 13 percent of the park area and terminates at Lees Ferry where the lake outflow becomes the Colorado River again (fig. 13). The dam that created the lake was constructed by the Bureau of Reclamation 
in 1963 and is the only major dam on the main stem of the Colorado River upstream from Lees Ferry. The remaining part of GLCA is a landscape of highly dissected red rock canyons, cliffs, and plateaus. Glen Canyon National Recreation Area was created by Congress in 1972 to "provide for public outdoor recreation use and enjoyment of Lake Powell and lands adjacent thereto in the states of Arizona and Utah and to preserve scenic, scientific, and historic features contributing to public enjoyment of the area" (National Park Service, 2006, p. 1). The Colorado River is the main drainage into Lake Powell, and the Paria, Escalante, San Juan, and Dirty Devil Rivers are major tributaries that flow into GLCA. More than 90 side canyons fed by springs and ephemeral drainages are considered tributaries to the main body of Lake Powell (Hart and others, 2005a).

GLCA has an arid climate with large seasonal variations in temperature and precipitation; generally, rainfall is highest in October and lowest in June, and snowfall predominates in December and January. Due to the large extent of this park, six selected climate stations in and surrounding GLCA were summarized to show the general range and variability of temperatures, precipitation, and snowfall for the area (table 17). On average, the coldest months are December and January and ranges from $12.3^{\circ}$ to $28.5^{\circ} \mathrm{C}$; July is the warmest month on average and ranges from $88.7^{\circ}$ to $103.4^{\circ} \mathrm{C}$. Average monthly precipitation is typically least in June and ranges from 0.15 to 0.47 inch and highest in late summer (July or August) or fall (October) and ranges from 0.74 to 1.19 inches. Mean annual precipitation is between 5.6 and 7.6 inches for all but Escalante (station 422592), which has an average precipitation of approximately 11 inches and is at a higher elevation. Average annual snowfall is low, ranging between 2.1 and 5.8 inches at five of the stations; Escalante recorded an average of 25.6 inches (Western Regional Climate Center, 2006).

\section{Geology}

GLCA was formed by downcutting of the Colorado and San Juan Rivers and their tributaries, which has exposed more than $8,000 \mathrm{ft}$ of bedrock and surficial deposits. The dominant bedrock unit in the park surrounding Lake Powell is the Jurassic Navajo Sandstone. The Navajo Sandstone, Kayenta Formation, and Wingate Sandstone form the red sandstone and mudstone that dominate the Glen Canyon Group (named for exposures in Glen Canyon) resulting in vertical cliffs more than 2,000 ft high (Nations and Stump, 1981; Anderson and others, 2003). The formations exposed in GLCA include the oldest Pennsylvanian formation, the Hermosa Group, followed by the Permian Cutler Group. The successively younger overlying rocks are the Triassic Chinle and Moenkopi Formations, which are in turn overlain by the Glen Canyon Group, followed by the San Rafael Group, Morrison Formation, Cretaceous Tropic Shale and Dakota Sandstone, and finally the Straight Cliffs Formation (Anderson and others, 2003).
The drainages of three perennial rivers analyzed for this section of the report - the Dirty Devil, Escalante, and Paria Rivers - are dominated by the Cutler Group and Moenkopi Formation (from mouth of Dirty Devil River to approximately 15 mi upstream), the Glen Canyon Group, and Quaternary alluvium. The Cutler Group includes very fine- to mediumgrained, quartz sandstone with siltstone and sandy shale, and minor amounts of coarse-grained sandstone, limestone, chert, magnetite, feldspar, or muscovite. The Moenkopi Formation is composed of siltstone, sandstone, claystone, limestone, and conglomerate with minor gypsum deposits. The Glen Canyon Group is a very fine- to medium-grained quartz sandstone with calcareous to iron-rich cements and some minor siltstone and shales (Anderson and others, 2003).

\section{Water Resources}

Major perennial rivers that flow into Lake Powell include the Colorado, Dirty Devil, Escalante, and San Juan Rivers. The Paria River flows into the Colorado River downstream from Glen Canyon Dam. Additional ephemeral streams, canyons, washes, and springs contribute water to GLCA. As of the writing of this report, 185 springs have been identified; it is believed that more than 600 springs may exist within GLCA (Thomas and others, 2006). These water bodies support critical wildlife habitat in the arid landscape, including riparian, wetland, lake, and spring habitats such as hanging gardens. Hanging gardens are well developed in the Navajo Sandstone along the banks of Lake Powell and in side canyons such as the Escalante Canyon (Anderson and others, 2003).

Continuous discharge is measured at multiple streamflow-gaging stations in Utah and Arizona on rivers that flow into and out of Lake Powell and in the larger GLCA area (table 18). Additional streamflow data are collected periodically or have been collected historically through these watersheds contributing to Lake Powell and the Lower Colorado River (U.S. Geological Survey, 2001). Streamflow characteristics are extremely variable between these basins. Winter months show the lowest mean monthly discharge for the Colorado (near Cisco) and San Juan Rivers; whereas, July shows the lowest mean monthly discharge for the Dirty Devil, Escalante, and Paria Rivers. The highest mean monthly discharge was recorded in the summer months, May through August, in all but the Dirty Devil River (March) and the Paria River (January). There is a lengthy record of 55 or more years at most of these stations, except for the Paria River sites, which have only operated as a real-time station since August 2002 and May 2004. The variability at the downstream Colorado River (Lees Ferry) site is minimal due to the carefully controlled releases from Lake Powell. A 2001 study of seepage in the Escalante River basin was completed by Wilberg and Stolp (2005) and concluded that large amounts of surface water are not lost or gained along the 15 evaluated reaches of the Escalante River. The Dirty Devil, Escalante, and Paria Rivers contribute substantially less water than the Colorado and San Juan Rivers when the ranges of minimum 
Table 17. Summary of temperature, precipitation, and snowfall records from six climate stations near Glen Canyon National Recreation Area, Arizona and Utah, 1901 to 2006.

[avg, average; AZ, Arizona; ${ }^{\circ}$, degrees Fahrenheit; max, maximum; min, minimum; precip, precipitation; Sta., station; temp, temperature; UT, Utah; data compiled from the Western Regional Climate Center (2006)]

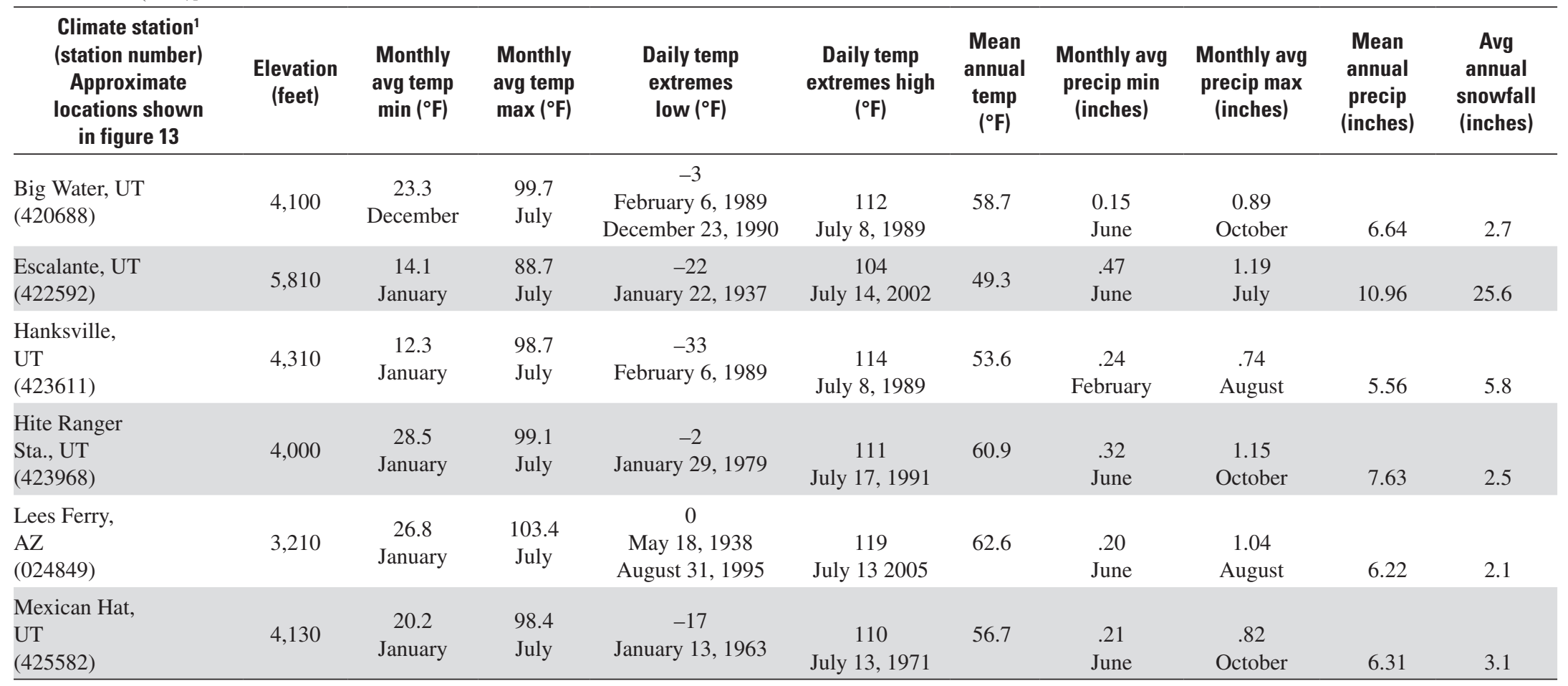

${ }^{1}$ Temperature data collected at Big Water from 1986 through 2006, at Escalante from 1901 through 2006, at Hanksville from 1948 through 2006 , at Hite Ranger Station from 1978 through 2006, at Lees Ferry from 1916 through 2006, and at Mexican Hat from 1948 through 2006. 
Table 18. Summary of real-time streamflow gages of major perennial rivers flowing into and out of Glen Canyon National Recreation Area, Arizona and Utah.

[abv, above; AZ, Arizona; est, estimated; fts/s, cubic feet per second; max, maximum; min, minimum; na, not available; nr, near; R, River; UT, Utah; all statistics from the National Water Information System (U.S. Geological Survey, 2001)]

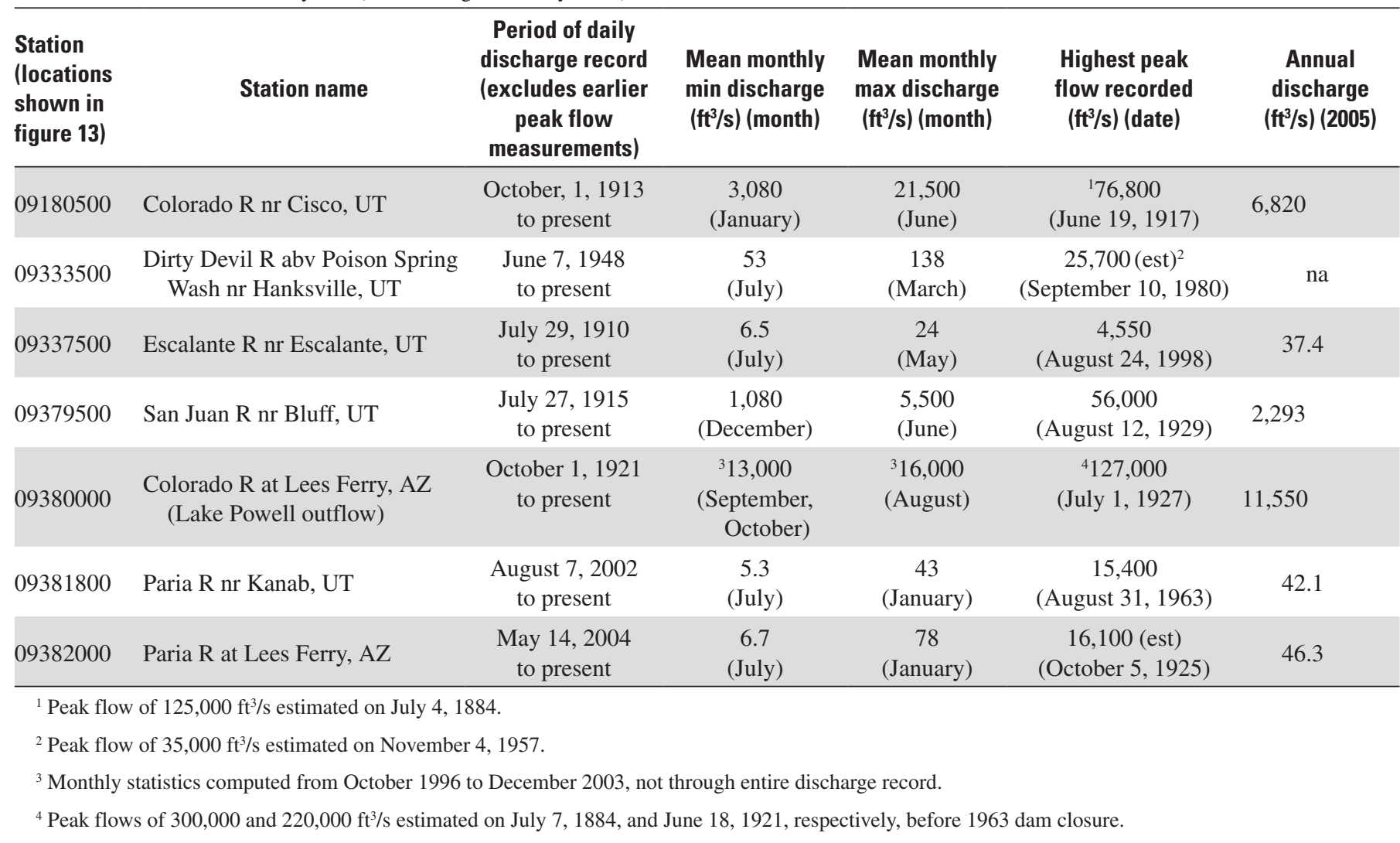

and maximum monthly streamflow among these sites are compared.

Multiple water-resource concerns exist at GLCA. All or parts of 35 grazing allotments that encompass more than $1,429 \mathrm{mi}^{2}$ within GLCA predate the creation of the park area. Cattle can affect riparian areas by trampling vegetation, depositing animal waste, causing streambank collapse and erosion, and damaging or removing native seedlings, which can facilitate the growth of exotic species. Off-road vehicle use in side canyons and in washes contributes to habitat deterioration and increased erosion (Thomas and others, 2006). Natural oil seeps and oil, gasoline, and other fuel-related contamination from personal and commercial watercraft used on Lake Powell affect water quality (Thomas and others, 2006; Hart and others, 2005a). Additionally, improperly disposed human waste can contribute pathogenic microorganisms and nutrients to the water. Upstream and adjacent land-use effects from road construction, grazing, mineral and energy resource extraction and processing, development, and wildfire also are water-resource-related concerns for the park area. Tributaries deposit significant sediment loads to Lake Powell, which can be enriched in nutrients (for example, phosphorus) and may accumulate contaminants, which are then deposited in the lake's deltas.
Hart and others (2005b) reported on sediment chemistry and potential chemical accumulation in Colorado River delta deposits.

The Paria River, from the Utah-Arizona border to the confluence with the Colorado River, was on the 2004 303(d) list in Arizona for suspended sediment and turbidity but was delisted for turbidity due to insufficient supporting data in December 2005 (Arizona Department of Environmental Quality, 2005). Upstream from the park boundary, the Escalante River is on the 2002 303(d) list for temperature for cold-water species of game fish and other aquatic life (beneficial use class 3A) from the confluence with Boulder Creek to the North Creek confluence (Millennium Science \& Engineering, Inc., 2005). Because the monitoring and assessment of water quality in Lake Powell, the Colorado River, and the San Juan River are the focus of other ongoing programs, this report will focus on other waters for the discussion on availability and characterization of water-quality data in GLCA. These other waters include three primary contributing perennial waters to GLCA, the Dirty Devil, Escalante, and Paria Rivers, along with a group of smaller contributing tributaries that flow into the Escalante River or directly into Lake Powell. 


\section{Available Water-Quality Data}

Data from 117 surface-water samples collected by the NPS, ADEQ, USGS, and UTDWQ between October 1947 and June 2003 were evaluated for this report to characterize water quality from samples of water flowing into and within the park in one of five stream groupings: three primary contributing perennial rivers (the Dirty Devil, Escalante, and Paria Rivers) and a composite of samples from a group of smaller tributaries that flow into Lake Powell and the Escalante River (fig. 13; table 19). Although there are additional ephemeral and intermittent streams, washes, and arroyos contributing water to GLCA, no data were available from these other water bodies to evaluate. An additional data reference for the Escalante River drainage basin from September 1909 through December 2002 is the USGS water-quality and streamflow data compilation by Wilberg and Stolp (2005).

The relative temporal distribution of samples and field measurements collected from stream sites flowing into and within the park (excluding the San Juan and Colorado Rivers, unnamed water bodies without data) and types of analyses conducted on samples are illustrated in figure 14. The relative temporal distribution of water samples and field measurements just from the Dirty Devil, Escalante, and Paria Rivers and types of analyses conducted on samples are illustrated in figure 15; the number of measurements of field properties and analyses of samples for major ions, nutrients, trace elements, and radiological constituents collected from these three rivers is summarized, by field property or constituent, in table 20. The number of water samples from the fourth and fifth groups of selected smaller tributaries to Lake Powell and the Escalante River is summarized, by major constituent class, in table 21. Generally, very few historical data are available and included sampling of only one site per year between 1947 and 1968, with no data collected in 1958, 1962, and 1964. During this period of limited sampling only the Paria River was sampled, except from 1951 to 1953 when the Escalante River was sampled. The Dirty Devil River was first sampled in 1969. The largest number of samples and measurements collected from these water bodies in any one year was in 1998 when 480 samples or measurements were collected from 41 sites on 18 different water bodies; 189 of these were collected from the Paria River. Sampling has been extremely variable over this 56-year period as evidenced by figures 14 and 15 .

Noticeable data gaps for GLCA are the lack of historical data between 1954 and 1968, when only a few field properties from only one site were measured. Data were collected less frequently from 1989 to 1994 than in periods directly preceding and following this time (fig. 14). Samples analyzed for trace-element data were collected very infrequently before 1975. The Dirty Devil River was sampled with various frequencies between 1969 and 1991, and it has been sampled only three times since 1991, in 1993, 1997, and 1998.

\section{Characterization of Water Quality}

Water data collected since 1988 from the Dirty Devil, Escalante, and Paria Rivers were assessed according to selected designated uses assigned by the State of Utah, including chronic aquatic-life cold and aquatic-life support exceedances, and secondary-contact recreation standards (table 20). Additionally, applicable sections of the Paria River were assessed according to designated uses assigned by the State of Arizona including chronic aquatic and wildlife warm-water exceedances and full-body contact standards. All historical data from these streams were summarized, including number of analyses, number of censored values, and minimum, maximum, and median values (table 20). Where possible, reported zero values were recensored to applicable censoring levels for determination of median values.

A second data and exceedance summary was compiled for the smaller intermittent or ephemeral tributaries flowing into the Escalante River or Lake Powell with one or more water-quality standard exceedance. Statistical data summaries were based on the complete period of record available and exceedances were based on evaluation of data collected since 1988 (table 21). These 14 waters, all within the Utah portion of GLCA, include five tributaries to the Escalante River (Coyote Gulch, East Moody Canyon, Harris Wash, Silver Falls Creek, and The Gulch) and nine tributaries to Lake Powell (Croton Canyon, Last Chance Creek, Little Valley Wash, North Wash, Tibbet Canyon, Trachyte Creek, Wahweap Creek, Wesses Canyon, and White Canyon Creek) shown in figure 13 and detailed in table 19. These streams all flow into the Escalante River or into Lake Powell (directly or through another tributary); no tributaries flowing into the Dirty Devil or Paria Rivers with exceedances were identified, and no tributaries flowing into the Colorado or San Juan Rivers were evaluated. Additionally, no tributary waters in the Arizona portion of GLCA matched these criteria. This summary includes just the 12 field properties and constituents with one or more State water-quality standard or Federal criterion exceedance (since 1988) identified for these waters; therefore, not all of the available water-quality data from the 14 evaluated tributaries are described in table 21 . The field properties and constituents are dissolved oxygen, $\mathrm{pH}$ (high), water temperature, and unfiltered phosphorus, and eight filtered trace elements: aluminum, barium, copper, iron, lead, manganese, mercury, and selenium. There are other smaller intermittent and ephemeral water bodies with water-quality data that flow into and within GLCA; however, these were not summarized herein because no exceedances were identified.

\section{Field Properties}

Collectively among the Dirty Devil, Escalante, and Paria Rivers, field properties, including DO, $\mathrm{pH}, \mathrm{SC}$, and water temperature, were measured $672,1,007,1,422$, and 1,340 times, 


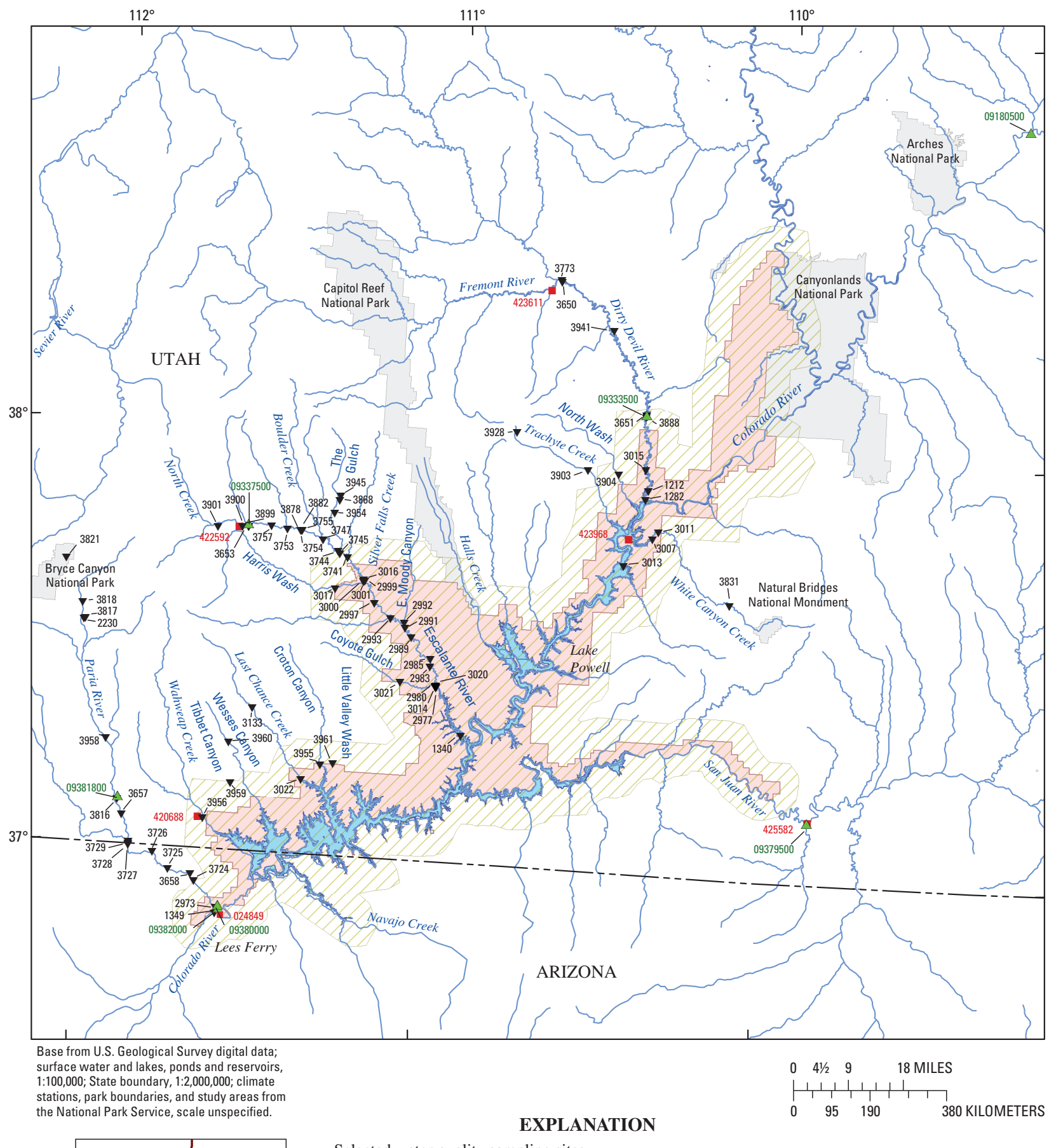

stations, park boundaries, and study areas from

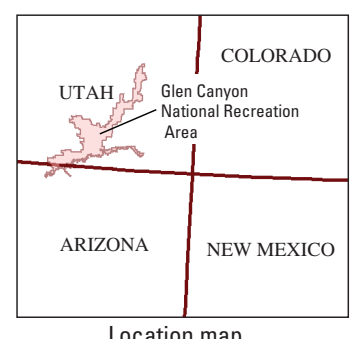

Selected water-quality sampling sites

$\nabla$ Surface water

3831 Site number

- Climate stations

$\triangle \quad$ Streamflow-gaging station

_ Intermittent streams

_ - - State boundary

EXPLANATION

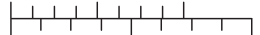

$0 \quad 95 \quad 190 \quad 380$ KILOMETERS

Location map

Figure 13. Glen Canyon National Recreation Area, Arizona and Utah, and locations of water-quality sampling sites. 
Table 19. Selected stream sites with water-quality data in or upstream from Glen Canyon National Recreation Area, Arizona and Utah, 1947 to 2003.

[AZ, Arizona; Cnfl, confluence; DD, decimal degrees; E, East; Mi, mile; Mtn, Mountain; NE, northeast; NNE, north-northeast; no., number; NRA, National Recreation Area; NW, northwest; Rd, road; S, south; Spr, spring; SW, southwest; UT, Utah; W, west; Xing, crossing; Site no. shown in figure 13; *, site located within park boundary; site names retained from original source database]

\begin{tabular}{|c|c|c|c|c|c|}
\hline $\begin{array}{l}\text { Site } \\
\text { no. }\end{array}$ & Site name & Latitude DD & Longitude DD & $\begin{array}{c}\text { No. of } \\
\text { samples }\end{array}$ & Period of record \\
\hline \multicolumn{6}{|c|}{ Dirty Devil River } \\
\hline $1212 *$ & Dirty Devil River near Hite, Utah 1.00 & 37.9158 & 110.3882 & 1 & 1976 \\
\hline $1282 *$ & Dirty Devil River at Lake Powell & 37.8972 & 110.3951 & 2 & 1991 \\
\hline $3015^{*}$ & Dirty Devil Inflow to Lake Powell & 37.9731 & 110.4000 & 1 & 1998 \\
\hline 3650 & Dirty Devil River near Hanksville, Utah & 38.4000 & 110.6840 & 2 & 1975-1976 \\
\hline 3651 & Dirty Devil River above Poison Spr Wash near Hanksville, UT & 38.0942 & 110.4074 & 186 & $1969-1991$ \\
\hline 3773 & Dirty Devil River above Little Meadow near Hanksville & 38.4069 & 110.6849 & 120 & 1973-1976 \\
\hline 3888 & Dirty Devil River above Cnfl / Poison Spring Wash & 38.0975 & 110.4064 & 179 & 1976-1998 \\
\hline 3941 & Dirty Devil River T29S R13E Sec17 NW1/4 NE1/4 & 38.2950 & 110.5186 & 1 & 1986 \\
\hline \multicolumn{6}{|c|}{$\begin{array}{ll}\text { Escalante River } \\
\end{array}$} \\
\hline $1340 *$ & Escalante River at mouth near Escalante, Utah & 37.3142 & 110.9035 & 82 & $1951-1953$ \\
\hline $2977 *$ & Escalante River at Coyote Gulch & 37.4280 & 110.9804 & 1 & 2001 \\
\hline $2980^{*}$ & Escalante River above Stevens Canyon & 37.4361 & 110.9818 & 1 & 2001 \\
\hline $2983 *$ & Escalante River above Fools Canyon & 37.4672 & 111.0018 & 1 & 2001 \\
\hline $2985^{*}$ & Escalante River 3.7-Miles above Fools Canyon & 37.4864 & 111.0027 & 1 & 2001 \\
\hline $2989 *$ & Escalante River above Scorpion Gulch & 37.5289 & 111.0629 & 1 & 2001 \\
\hline $2992 *$ & Escalante River below Moody Creek & 37.5655 & 111.0865 & 1 & 2001 \\
\hline $2993 *$ & Escalante River above 25-Mile Wash & 37.5794 & 111.1290 & 1 & 2001 \\
\hline $2997 *$ & Escalante River above Fence Canyon & 37.6128 & 111.1791 & 2 & $1981-2001$ \\
\hline $2999 *$ & Escalante River above Harris Wash & 37.6628 & 111.2157 & 10 & $2001-2003$ \\
\hline $3014 *$ & Escalante River above Lake Powell & 37.4319 & 110.9836 & 33 & $1997-2003$ \\
\hline 3653 & Escalante River near Escalante, UT & 37.7780 & 111.5746 & 160 & 1969-2001 \\
\hline 3741 & Escalante River above Horse Canyon & 37.7186 & 111.2674 & 1 & 2001 \\
\hline 3744 & Escalante River above The Gulch & 37.7253 & 111.2974 & 2 & 2001 \\
\hline 3747 & Escalante River above Boulder Creek & 37.7569 & 111.3502 & 2 & $1981-2001$ \\
\hline 3753 & Escalante River above Sand Creek & 37.7750 & 111.4579 & 1 & 2001 \\
\hline 3754 & Escalante River above Calf Creek & 37.7755 & 111.4185 & 1 & 2001 \\
\hline 3755 & Escalante River below Calf Creek & 37.7764 & 111.4163 & 3 & $2001-2002$ \\
\hline 3757 & Escalante River above Mamie Creek & 37.7805 & 111.5060 & 2 & $1981-2001$ \\
\hline 3878 & Escalante River below Cnfl / Calf Creek & 37.7764 & 111.4158 & 19 & $1976-1978$ \\
\hline 3882 & Escalante River above Cnfl / Calf Creek & 37.7756 & 111.4183 & 139 & $1978-2003$ \\
\hline 3899 & Escalante River below Cnfl / Pine Creek & 37.7781 & 111.5739 & 10 & 1982-1984 \\
\hline 3900 & Escalante River NE of Escalante at River Ford & 37.7767 & 111.5928 & 9 & $1980-1982$ \\
\hline 3901 & Escalante River $3.5 \mathrm{mi} \mathrm{W}$ of Town at Weir Gage & 37.7725 & 111.6661 & 50 & $1980-2003$ \\
\hline \multicolumn{6}{|c|}{ Paria River } \\
\hline $1349 *$ & Paria River at Lees Ferry, AZ & 36.8722 & 111.5946 & 1,395 & $1947-2000$ \\
\hline 2230 & Paria River at Rd Xing near Cannonville, Utah & 37.5283 & 112.0441 & 1 & 1974 \\
\hline $2973 *$ & Cmpar000.55 & 36.8643 & 111.5965 & 12 & $1998-2000$ \\
\hline 3657 & Paria River at White House Ruins near Glen Canyon, UT & 37.0753 & 111.8905 & 27 & 1977-1979 \\
\hline 3658 & Paria River below Water Pockets Gulch near Page, AZ & 36.9464 & 111.6763 & 26 & 1977-1979 \\
\hline 3724 & Cmpar007.95 & 36.9319 & 111.6643 & 12 & $1998-2000$ \\
\hline 3725 & Cmpar013.79 & 36.9566 & 111.7430 & 12 & $1998-2000$ \\
\hline 3726 & Cmpar022.37 & 36.9952 & 111.7928 & 13 & 1998-2000 \\
\hline 3727 & Cmpar029.87 & 37.0009 & 111.8643 & 12 & $1998-2000$ \\
\hline
\end{tabular}


Table 19. Selected stream sites with water-quality data in or upstream from Glen Canyon National Recreation Area, Arizona and Utah, 1947 to 2003.-Continued

[AZ, Arizona; Cnfl, confluence; DD, decimal degrees; E, East; Mi, mile; Mtn, Mountain; NE, northeast; NNE, north-northeast; no., number; NRA, National Recreation Area; NW, northwest; Rd, road; S, south; Spr, spring; SW, southwest; UT, Utah; W, west; Xing, crossing; Site no. shown in figure 13; *, site located within park boundary; site names retained from original source database]

\begin{tabular}{|c|c|c|c|c|c|}
\hline $\begin{array}{l}\text { Site } \\
\text { no. }\end{array}$ & Site name & Latitude DD & Longitude DD & $\begin{array}{l}\text { No. of } \\
\text { samples }\end{array}$ & Period of record \\
\hline \multicolumn{6}{|c|}{ Paria River-Continued } \\
\hline 3728 & Cmpar029.90 & 37.0019 & 111.8646 & 12 & $1998-2000$ \\
\hline 3729 & Cmpar030.00 & 37.0014 & 111.8656 & 12 & $1998-2000$ \\
\hline 3816 & Paria River at US89 Xing & 37.1075 & 111.9061 & 122 & $1976-2003$ \\
\hline 3817 & Paria River at Kodachrome Basin Rd Xing & 37.5281 & 112.0434 & 30 & $2000-2003$ \\
\hline 3818 & Paria River at U12 Xing & 37.5675 & 112.0506 & 41 & $1981-2003$ \\
\hline 3821 & Paria River $3 \mathrm{Mi}$ NNE of Tropic & 37.6664 & 112.1089 & 9 & 1997-1998 \\
\hline 3958 & Paria River at Old Town Site & 37.2505 & 111.9535 & 59 & $1998-2003$ \\
\hline \multicolumn{6}{|c|}{ Tributaries to the Escalante River } \\
\hline \multicolumn{6}{|c|}{ Coyote Gulch } \\
\hline $3020 *$ & Coyote Gulch above Escalante River & 37.4286 & 110.9808 & 3 & 1998-1999 \\
\hline $3021 *$ & Coyote Gulch at NRA Fence & 37.4275 & 111.0872 & 13 & $1998-2003$ \\
\hline \multicolumn{6}{|c|}{ East Moody Canyon } \\
\hline $2991 *$ & East Moody Canyon at mouth & 37.5583 & 111.0835 & 1 & 2001 \\
\hline \multicolumn{6}{|c|}{ Harris Wash } \\
\hline $3000 *$ & Harris Wash at mouth & 37.6633 & 111.2160 & 2 & 2001 \\
\hline $3016^{*}$ & Harris Wash above Cnfl/ Escalante River & 37.6636 & 111.2156 & 8 & $2002-2003$ \\
\hline $3017 *$ & Harris Wash at NRA Fence & 37.6400 & 111.2992 & 3 & $1998-2000$ \\
\hline \multicolumn{6}{|c|}{ Silver Falls Creek } \\
\hline $3001 *$ & Silver Falls Creek at mouth & 37.6669 & 111.2121 & 1 & 2001 \\
\hline \multicolumn{6}{|c|}{$\begin{array}{lr} & \text { The Gulch } \\
\end{array}$} \\
\hline 3745 & The Gulch at mouth near Confluence with Escalante & 37.7255 & 111.2974 & 3 & $1998-2001$ \\
\hline 3868 & The Gulch Creek in Long Canyon at Burr Trail Xing & 37.8558 & 111.3086 & 100 & $1980-2003$ \\
\hline 3945 & The Gulch above Cnfl/ Steep Creek & 37.8633 & 111.3117 & 5 & $1998-2000$ \\
\hline 3954 & The Gulch at Roundy Cabin & 37.8194 & 111.3208 & 3 & $1998-2000$ \\
\hline \multicolumn{6}{|c|}{ Tributaries to Lake Powell } \\
\hline \multicolumn{6}{|c|}{$\begin{array}{ll}\text { Croton Canyon } \\
\end{array}$} \\
\hline 3955 & Croton Canyon 1/3 Mi below Grand Bench Rd Xing & 37.2275 & 111.3144 & 17 & $1998-2002$ \\
\hline \multicolumn{6}{|c|}{ Last Chance Creek } \\
\hline $3022 *$ & Last Chance at Burning Hills Rd Xing & 37.1842 & 111.3678 & 37 & $1998-2003$ \\
\hline 3133 & Last Chance Creek at Smokey Mtn Rd Xing & 37.3467 & 111.5256 & 1 & 1998 \\
\hline \multicolumn{6}{|c|}{ Little Valley Wash } \\
\hline 3961 & Little Valley Wash at Grand Bench Rd Xing & 37.2331 & 111.2778 & 21 & $1998-2002$ \\
\hline \multicolumn{6}{|c|}{ North Wash } \\
\hline $3013 *$ & North Wash above Lake Powell & 37.7364 & 110.4500 & 11 & $1997-1998$ \\
\hline 3904 & North Wash below Hog Springs & 37.9592 & 110.4808 & 11 & 1997-1998 \\
\hline \multicolumn{6}{|c|}{ Tibbet Canyon } \\
\hline 3959 & Tibbet Canyon $2 \mathrm{Mi}$ above Cnfl/ Warm Creek & 37.1728 & 111.5769 & 5 & 1998-2002 \\
\hline \multicolumn{6}{|c|}{$\begin{array}{lr} & \text { Trachyte Creek } \\
\end{array}$} \\
\hline 3903 & Trachyte Creek at U276 Xing above Cnfl / Black Creek & 37.9581 & 110.5725 & 19 & $1985-1998$ \\
\hline 3928 & $\begin{array}{l}\text { Slate C 1mi above Salt Flat at Road Xing 32S R10E } \\
\text { Sec10SW1/4NE1/4 }\end{array}$ & 38.0403 & 110.7919 & 7 & $1980-1996$ \\
\hline
\end{tabular}


Table 19. Selected stream sites with water-quality data in or upstream from Glen Canyon National Recreation Area, Arizona and Utah, 1947 to 2003.-Continued

[AZ, Arizona; Cnfl, confluence; DD, decimal degrees; E, East; Mi, mile; Mtn, Mountain; NE, northeast; NNE, north-northeast; no., number; NRA, National Recreation Area; NW, northwest; Rd, road; S, south; Spr, spring; SW, southwest; UT, Utah; W, west; Xing, crossing; Site no. shown in figure 13; *, site located within park boundary; site names retained from original source database]

\begin{tabular}{|c|c|c|c|c|c|}
\hline $\begin{array}{l}\text { Site } \\
\text { no. }\end{array}$ & Site name & Latitude DD & Longitude DD & $\begin{array}{c}\text { No. of } \\
\text { samples }\end{array}$ & Period of record \\
\hline \multicolumn{6}{|c|}{ Tributaries to Lake Powell-Continued } \\
\hline \multicolumn{6}{|c|}{ Wahweap Creek } \\
\hline 3956 & Wahweap Creek at Warm Creek Rd Xing & 37.0808 & 111.6508 & 59 & $1998-2003$ \\
\hline \multicolumn{6}{|c|}{ Wesses Canyon } \\
\hline 3960 & Wesses Canyon at Cow Camp & 37.2619 & 111.5897 & 5 & 1998-2002 \\
\hline \multicolumn{6}{|c|}{ White Canyon Creek } \\
\hline $3007 *$ & White Canyon at mouth & 37.8053 & 110.3683 & 3 & $1979-1980$ \\
\hline $3011 *$ & White Canyon Creek above Lake Powell & 37.8200 & 110.3508 & 12 & 1997-1998 \\
\hline 3831 & White Canyon Creek E of Fry Canyon & 37.6564 & 110.1278 & 11 & 1997-1998 \\
\hline
\end{tabular}

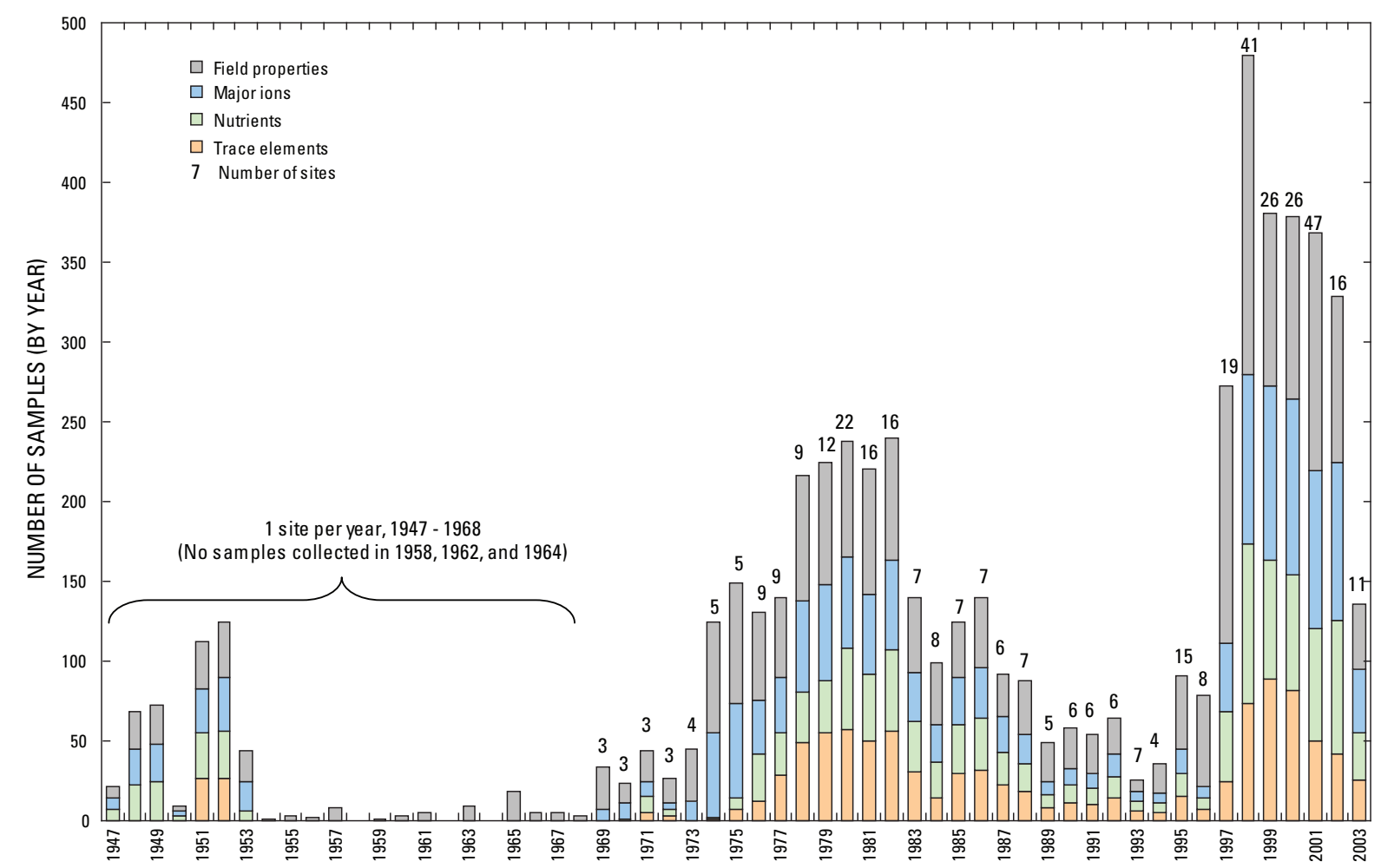

Figure 14. Total number of sites and samples for field properties and major ions, nutrients, and trace elements collected from selected streams, excluding the Colorado and San Juan Rivers, and unnamed waters, flowing into and within Glen Canyon National Recreation Area, Arizona and Utah, 1947 to 2003. [Water sources represented in graph include Bullfrog Creek, Coyote Gulch, Croton Canyon, Dark Canyon, Dark Canyon Creek, Dirty Devil River, East Moody Canyon, Escalante River, Fence Canyon, Fools Canyon, Fortymile Gulch, Grand Gulch, Gypsum Canyon, Halls Creek, Harris Wash, Horse Canyon, Kane Gulch, Lake Canyon, Last Chance Creek, Lime Creek, Little Valley Wash, Maidenwater Creek, Moqui Canyon, Neon Canyon, North Wash, Paria River, Pennell Creek, Red Canyon, Ruin Canyon, Scorpion Gulch, Silver Falls Creek, Stevens Canyon, Stillwater Canyon, The Gulch, Tibbet Canyon, Trachyte Creek, Twentyfive Mile Wash, Wahweap Creek, Warm Creek, Wesses Canyon, White Canyon Creek]. 


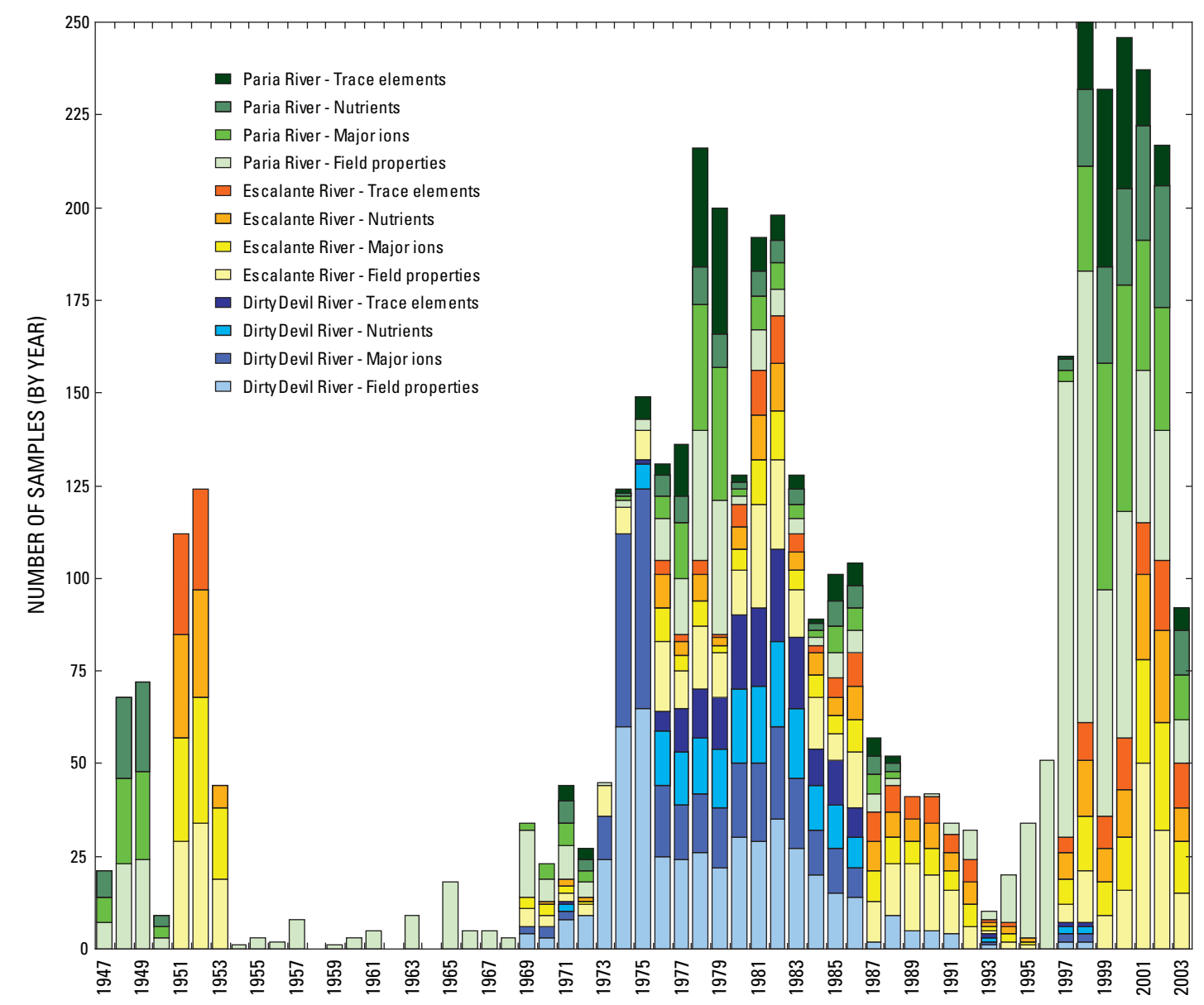

Figure 15. Total number of water samples collected from the Dirty Devil, Escalante, and Paria Rivers for field properties, major ions, nutrients, and trace elements, Glen Canyon National Recreation Area, Arizona and Utah, 1947 to 2003.

respectively, between 1947 and 2003. Hardness and turbidity also were measured throughout this period in all three rivers, though less frequently. Streamflow was measured frequently in the Paria River (1,153 times) and at about the same frequency as the other field properties in the other two rivers. Measured values of $\mathrm{DO}, \mathrm{pH}$, turbidity, and water temperature exceeded the Utah or Arizona aquatic-life or recreationalcontact standards in one or all of these waters between 1988 and 2003 (table 20). For the 14 evaluated tributaries summarized in table 21, measurements of $\mathrm{DO}, \mathrm{pH}$, and water temperature were made much less frequently, and most streams or washes were sampled fewer than 20 times, except for The Gulch (sampled between 93 and 102 times), Last Chance Creek (sampled between 18 and 44 times), and Wahweap Creek (sampled between 35 and 57 times). These three field properties were exceeded between one and eight times in these tributary waters.
Six out of 117 DO measurements (sites 3882 and 3901) did not meet the Utah minimum DO standard of $6.5 \mathrm{mg} / \mathrm{L}$ in the Escalante River and one out of 109 measurements exceeded this standard at site 3958 in the Paria River. Between one and three values exceeded the aquatic-life warm-water DO standard of $5.5 \mathrm{mg} / \mathrm{L}$ out of 68 measurements (from five streams) in the evaluated tributaries. The Arizona aquatic and wildlife warm-water standard of $6 \mathrm{mg} / \mathrm{L}$ was not met for 20 out of 71 measurements (sites 2973, 3724, 3725, 3726, 3727, 3728, and 3729) in the Paria River. Low DO concentrations can be a sign of elevated concentrations of organic compounds or nutrients or high turbidity levels and can be harmful to biological community function and health below $5 \mathrm{mg} / \mathrm{L}$ (Chapman, 1998).

$\mathrm{A} \mathrm{pH}$ value exceeding the aquatic and wildlife warmwater and full-body contact standards of $9 \mathrm{SU}$ in Arizona was observed once at site 3727 out of 71 measurements in the Paria River. Historical pH measurements made before 1988, but 
Table 20. Statistical summary of water-quality data and exceedances of water-quality standards for selected stream-sampling sites in the Dirty Devil, Escalante, and Paria Rivers located in and upstream from Glen Canyon National Recreation Area, Arizona and Utah, 1947 to 2003 .

[ac sol, acid soluble; AWW, aquatic and wildlife warm water (AZ); AZ, Arizona; AZDEQ, Arizona Department of Environmental Quality; deg C, degrees Celsius; EPA RC III, U.S. Environmental Protection Agency National Recommended Nutrient Criteria for Ecoregion III; FBC, full-body contact (AZ); fil, filtered; H, high (maximum) standard; L, low (minimum) standard; mg/L, milligrams per liter; N, nitrogen; No., number; NTU, nephelometric turbidity units; P, phosphorus; POR, period of record; R, River; rec, recoverable; TVS, table value standard; TVS 100, table value standard computed at a hardness of $100 \mathrm{mg} / \mathrm{L}$ (provided as a baseline for comparison, site-specific TVS used for exceedance analysis); unfil, unfiltered; unsp, unspeciated; UT, Utah; UTDEQ, Utah Department of Environmental Quality; $\mu \mathrm{S} / \mathrm{cm}$, microsiemens per centimeter; <, less than; --, not available or not computed; 2B, secondary-contact recreation (UT); 3A, aquatic-life cold (UT); 3C, aquatic-life support (UT); 30d, 30-day average; III, chromium III; *, extreme outlier excluded; bold type indicates exceedance during recent POR]

\begin{tabular}{|c|c|c|c|c|c|c|c|}
\hline \multirow{2}{*}{$\begin{array}{l}\text { Selected } \\
\text { streams } \\
\text { (see fig. } 13 \text { for } \\
\text { location of } \\
\text { streams) }\end{array}$} & \multirow[b]{2}{*}{$\begin{array}{l}\text { Field property } \\
\text { or constituent } \\
\text { (reporting units) }\end{array}$} & \multicolumn{4}{|c|}{$\begin{array}{c}\text { Complete POR } \\
1947 \text { to } 2003^{1} \\
\end{array}$} & \multicolumn{2}{|c|}{$\begin{array}{l}\text { Recent POR } \\
1988 \text { to } 2003 \\
\end{array}$} \\
\hline & & $\begin{array}{c}\text { No. of } \\
\text { analyses/No. } \\
\text { of censored } \\
\text { values }\end{array}$ & $\begin{array}{l}\text { Minimum } \\
\text { value }\end{array}$ & $\begin{array}{l}\text { Median } \\
\text { value }\end{array}$ & $\begin{array}{l}\text { Maximum } \\
\text { value }\end{array}$ & $\begin{array}{l}\text { UTDEQ or AZDEO } \\
\text { standard or } \\
\text { Federal criteria } \\
(\text { Use })^{2}\end{array}$ & $\begin{array}{l}\text { No. of exceedances/ } \\
\text { No. of analyses/ } \\
\text { No. of sites with } \\
\text { exceedances (Use) }\end{array}$ \\
\hline \multicolumn{8}{|c|}{ Field properties (1947-2003) } \\
\hline Escalante R & Dissolved oxygen (mg/L) & $211 / 0$ & 4.8 & 8.5 & 13.57 & 6.5 (UT 3A,30d) & $\begin{array}{l}0 / 14 / 0(3 \mathrm{C}) \\
\mathbf{6 / 1 1 7 / 2 ( 3 A )}\end{array}$ \\
\hline Paria R & Dissolved oxygen (mg/L) & $314 / 0$ & 3.9 & 8.3 & 14.8 & 6 (AZ AWW) & $\begin{array}{c}\text { 1/109/1 (3A) } \\
\text { 20/71/7 (AWW) }\end{array}$ \\
\hline Dirty Devil R & $\begin{array}{l}\text { Hardness, unfil } \\
\qquad\left(\mathrm{mg} / \mathrm{L} \text { as } \mathrm{CaCO}_{3}\right)\end{array}$ & $141 / 0$ & 340 & 670 & 1,900 & -- & -- \\
\hline Dirty Devil R & $\mathrm{pH}$ (standard units) & $306 / 0$ & 6.5 & 8.0 & 9.1 & \multirow{2}{*}{$\begin{array}{l}6.5, \mathrm{~L} \\
9, \mathrm{H} \\
(\mathrm{UT} 2 \mathrm{~B}, 3 \mathrm{~A}, 3 \mathrm{C})\end{array}$} & $\begin{array}{l}0 / 5 / 0, \mathrm{~L}(2 \mathrm{~B}, 3 \mathrm{C}) \\
0 / 5 / 0, \mathrm{H}(2 \mathrm{~B}, 3 \mathrm{C})\end{array}$ \\
\hline Escalante R & $\mathrm{pH}$ (standard units) & $316 / 0$ & 6.58 & 8.2 & 10.2 & & $\begin{array}{l}0 / 157 / 0, \mathrm{~L}(2 \mathrm{~B}) \\
0 / 157 / 0, \mathrm{H}(2 \mathrm{~B}) \\
0 / 132 / 0, \mathrm{~L}(3 \mathrm{~A}) \\
0 / 132 / 0, \mathrm{H}(3 \mathrm{~A})\end{array}$ \\
\hline Paria R & $\mathrm{pH}$ (standard units) & $385 / 0$ & 6 & 8.2 & 9.7 & $\begin{array}{l}6.5, \mathrm{~L} \\
9.0, \mathrm{H} \\
(\mathrm{AZ} \text { AWW, } \\
\quad \text { FBC) }\end{array}$ & $\begin{array}{c}\text { 0/166/0, L (2B,3C) } \\
\text { 0/166/0, H }(2 \mathrm{~B}, 3 \mathrm{C}) \\
\text { 0/71/0, L (AWW,FBC) } \\
\mathbf{1 / 7 1 / 1 , ~ H ~ ( A W W , F B C ) ~}\end{array}$ \\
\hline Escalante R & \multirow{2}{*}{$\begin{array}{l}\text { Streamflow (cubic feet } \\
\text { per second) }\end{array}$} & $342 / 0$ & 0 & 12 & 322.6 & \multirow[t]{2}{*}{--} & \multirow[t]{2}{*}{--} \\
\hline Paria R & & $1,153 / 0$ & 0 & 17 & 6,270 & & \\
\hline
\end{tabular}


Table 20. Statistical summary of water-quality data and exceedances of water-quality standards for selected stream-sampling sites in the Dirty Devil, Escalante, and Paria Rivers located in and upstream from Glen Canyon National Recreation Area, Arizona and Utah, 1947 to 2003.-Continued

[ac sol, acid soluble; AWW, aquatic and wildlife warm water (AZ); AZ, Arizona; AZDEQ, Arizona Department of Environmental Quality; deg C, degrees Celsius; EPA RC III, U.S. Environmental Protection Agency National Recommended Nutrient Criteria for Ecoregion III; FBC, full-body contact (AZ); fil, filtered; H, high (maximum) standard; L, low (minimum) standard; mg/L, milligrams per liter; N, nitrogen; No., number; NTU, nephelometric turbidity units; P, phosphorus; POR, period of record; R, River; rec, recoverable; TVS, table value standard; TVS 100, table value standard computed at a hardness of $100 \mathrm{mg} / \mathrm{L}$ (provided as a baseline for comparison, site-specific TVS used for exceedance analysis); unfil, unfiltered; unsp, unspeciated; UT, Utah; UTDEQ, Utah Department of Environmental Quality; $\mu \mathrm{S} / \mathrm{cm}$, microsiemens per centimeter; <, less than; --, not available or not computed; 2B, secondary-contact recreation (UT); 3A, aquatic-life cold (UT); 3C, aquatic-life support (UT); 30d, 30-day average; III, chromium III; *, extreme outlier excluded; bold type indicates exceedance during recent POR]

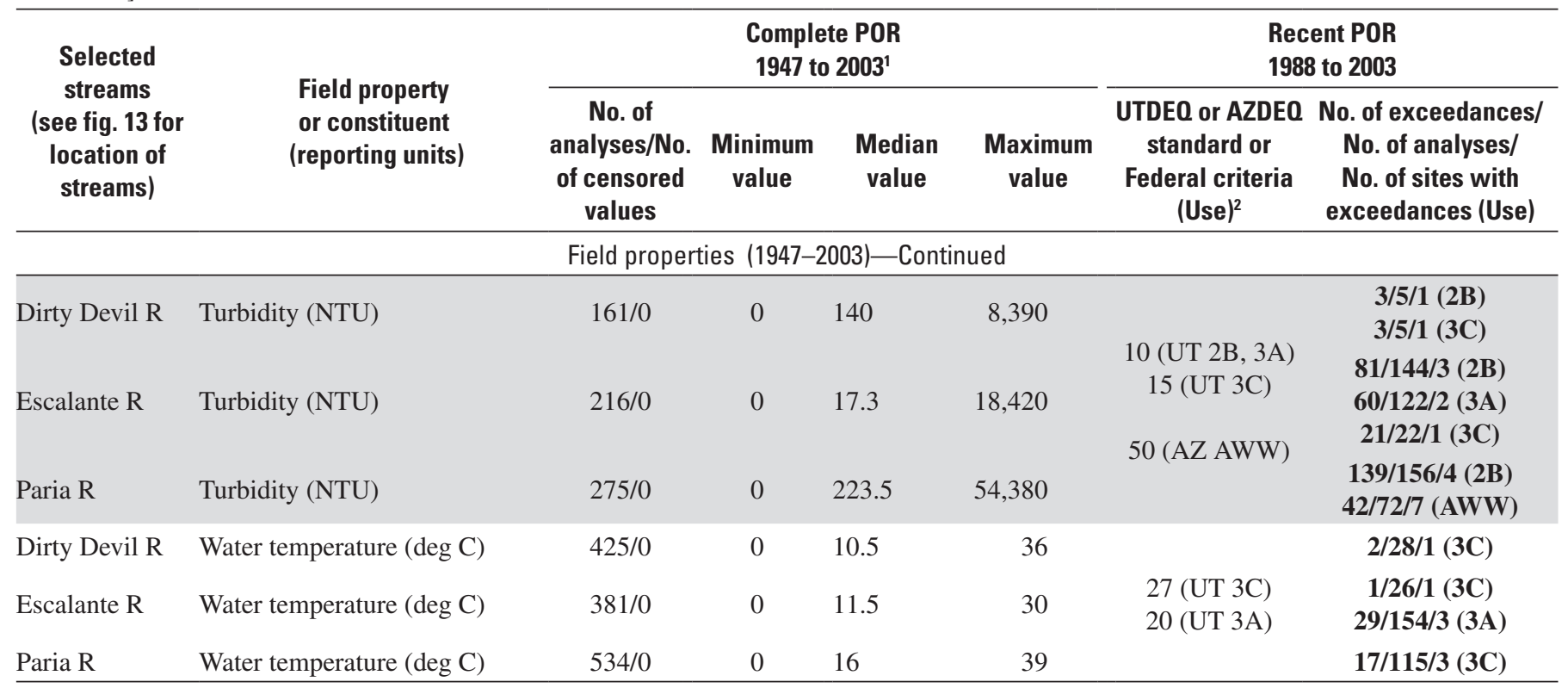

Nutrients (aggregated) ${ }^{3}(1947-2003)$

(Zero values excluded except where able to recensor to censoring level)

\begin{tabular}{|c|c|c|c|c|c|c|c|}
\hline Dirty Devil R & Ammonia, unfil (mg/L as $\mathrm{N})$ & $159 / 64$ & $<.01$ & .082 & 1.40 & \multirow{3}{*}{ UT TVS } & $0 / 132 / 0 /(3 C)$ \\
\hline Escalante R & Ammonia, unfil (mg/L as $\mathrm{N})$ & $137 / 113$ & $<.01$ & .025 & .329 & & 0/118/0 (3A) \\
\hline Paria R & Ammonia, unfil (mg/L as $\mathrm{N})$ & $91 / 60$ & $<.01$ & .028 & .740 & & $0 / 87 / 0(3 \mathrm{C})$ \\
\hline Dirty Devil R & Nitrate $(\mathrm{mg} / \mathrm{L}$ as $\mathrm{N})$ & $99 / 0$ & .011 & .158 & 1.75 & 4 (UT 3A, 3C) & -- \\
\hline Escalante $\mathrm{R}$ & Nitrate $(\mathrm{mg} / \mathrm{L}$ as $\mathrm{N})$ & $130 / 3$ & $<.1$ & .090 & 1.45 & $\begin{array}{c}2,240 \\
(\mathrm{AZ} \mathrm{FBC})\end{array}$ & $0 / 20 / 0(3 \mathrm{~A})$ \\
\hline Dirty Devil R & Nitrogen, unfil (mg/L as N) & $70 / 0$ & .12 & 1.04 & 23 & \multirow{3}{*}{$\begin{array}{c}0.38 \\
\text { EPA RC III }\end{array}$} & -- \\
\hline Escalante R & Nitrogen, unfil (mg/L as $\mathrm{N}$ ) & $57 / 0$ & .002 & .328 & 14.9 & & 5/19/1 (EPA RC III) \\
\hline Paria R & Nitrogen, unfil (mg/L as $\mathrm{N})$ & $43 / 0$ & .218 & 1.26 & 34.3 & & 0/2/0 (EPA RC III) \\
\hline Dirty Devil R & $\begin{array}{l}\text { Orthophosphorus } \\
(\mathrm{mg} / \mathrm{L} \text { as } \mathrm{P})\end{array}$ & $108 / 30$ & $<.01$ & .020 & .94 & -- & -- \\
\hline Dirty Devil R & $\begin{array}{l}\text { Total phosphorus, unfil } \\
(\mathrm{mg} / \mathrm{L} \text { as } \mathrm{P})\end{array}$ & $147 / 5$ & $<.02$ & .500 & 21 & \multirow{3}{*}{$\begin{array}{c}0.05 \\
(\mathrm{UT} 2 \mathrm{~B}, 3 \mathrm{~A})\end{array}$} & $2 / 3 / 2(2 B)$ \\
\hline Escalante R & $\begin{array}{l}\text { Total phosphorus, unfil } \\
(\mathrm{mg} / \mathrm{L} \text { as } \mathrm{P})\end{array}$ & $192 / 20$ & $<.02$ & .050 & 2.81 & & $\begin{array}{l}51 / 125 / 4(2 B) \\
39 / 103 / 3(3 A)\end{array}$ \\
\hline Paria R & $\begin{array}{l}\text { Total phosphorus, unfil } \\
(\mathrm{mg} / \mathrm{L} \text { as } \mathrm{P})\end{array}$ & $203 / 16$ & $<.02$ & .131 & 9.4 & & 97/140/4 (2B) \\
\hline
\end{tabular}


Table 20. Statistical summary of water-quality data and exceedances of water-quality standards for selected stream-sampling sites in the Dirty Devil, Escalante, and Paria Rivers located in and upstream from Glen Canyon National Recreation Area, Arizona and Utah, 1947 to 2003.-Continued

[ac sol, acid soluble; AWW, aquatic and wildlife warm water (AZ); AZ, Arizona; AZDEQ, Arizona Department of Environmental Quality; deg C, degrees Celsius; EPA RC III, U.S. Environmental Protection Agency National Recommended Nutrient Criteria for Ecoregion III; FBC, full-body contact (AZ); fil, filtered; H, high (maximum) standard; L, low (minimum) standard; mg/L, milligrams per liter; N, nitrogen; No., number; NTU, nephelometric turbidity units; P, phosphorus; POR, period of record; R, River; rec, recoverable; TVS, table value standard; TVS 100, table value standard computed at a hardness of $100 \mathrm{mg} / \mathrm{L}$ (provided as a baseline for comparison, site-specific TVS used for exceedance analysis); unfil, unfiltered; unsp, unspeciated; UT, Utah; UTDEQ, Utah Department of Environmental Quality; $\mu \mathrm{S} / \mathrm{cm}$, microsiemens per centimeter; <, less than; --, not available or not computed; 2B, secondary-contact recreation (UT); 3A, aquatic-life cold (UT); 3C, aquatic-life support (UT); 30d, 30-day average; III, chromium III; *, extreme outlier excluded; bold type indicates exceedance during recent POR]

\begin{tabular}{|c|c|c|c|c|c|c|c|}
\hline \multirow{2}{*}{$\begin{array}{l}\text { Selected } \\
\text { streams } \\
\text { (see fig. } 13 \text { for } \\
\text { location of } \\
\text { streams) }\end{array}$} & \multirow[b]{2}{*}{$\begin{array}{l}\text { Field property } \\
\text { or constituent } \\
\text { (reporting units) }\end{array}$} & \multicolumn{4}{|c|}{$\begin{array}{c}\text { Complete POR } \\
1947 \text { to } 2003^{1}\end{array}$} & \multicolumn{2}{|c|}{$\begin{array}{l}\text { Recent POR } \\
1988 \text { to } 2003\end{array}$} \\
\hline & & $\begin{array}{c}\text { No. of } \\
\text { analyses/No. } \\
\text { of censored } \\
\text { values }\end{array}$ & $\begin{array}{l}\text { Minimum } \\
\text { value }\end{array}$ & $\begin{array}{l}\text { Median } \\
\text { value }\end{array}$ & $\begin{array}{l}\text { Maximum } \\
\text { value }\end{array}$ & $\begin{array}{l}\text { UTDEQ or AZDEQ } \\
\text { standard or } \\
\text { Federal criteria } \\
(\text { Use })^{2}\end{array}$ & $\begin{array}{l}\text { No. of exceedances/ } \\
\text { No. of analyses/ } \\
\text { No. of sites with } \\
\text { exceedances (Use) }\end{array}$ \\
\hline
\end{tabular}

Trace elements (1971-2003)

(Results reported in micrograms per liter; zero values excluded except where able to recensor to censoring level)

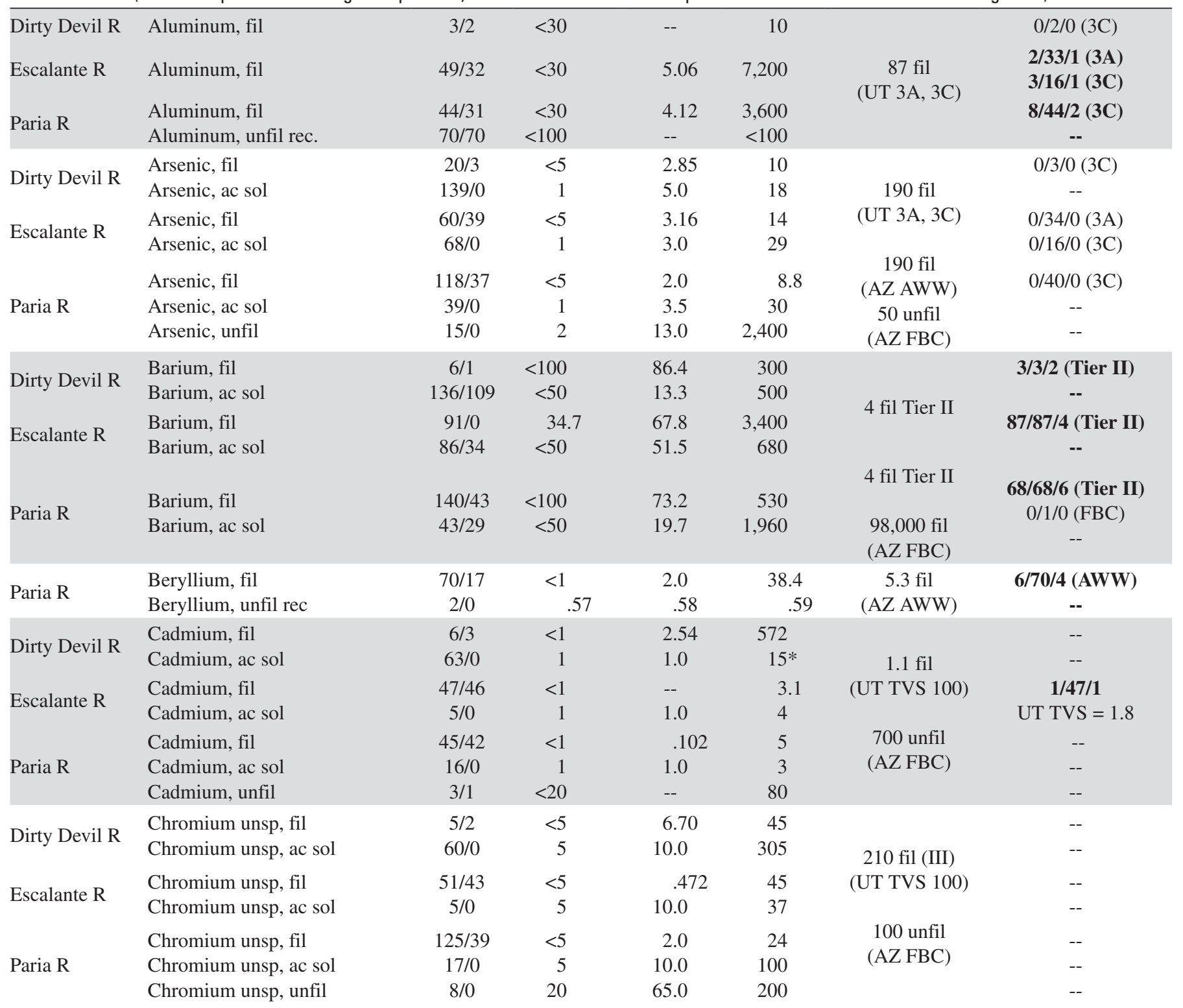


Table 20. Statistical summary of water-quality data and exceedances of water-quality standards for selected stream-sampling sites in the Dirty Devil, Escalante, and Paria Rivers located in and upstream from Glen Canyon National Recreation Area, Arizona and Utah, 1947 to 2003.-Continued

[ac sol, acid soluble; AWW, aquatic and wildlife warm water (AZ); AZ, Arizona; AZDEQ, Arizona Department of Environmental Quality; deg C, degrees Celsius; EPA RC III, U.S. Environmental Protection Agency National Recommended Nutrient Criteria for Ecoregion III; FBC, full-body contact (AZ); fil, filtered; H, high (maximum) standard; L, low (minimum) standard; mg/L, milligrams per liter; N, nitrogen; No., number; NTU, nephelometric turbidity units; P, phosphorus; POR, period of record; R, River; rec, recoverable; TVS, table value standard; TVS 100, table value standard computed at a hardness of $100 \mathrm{mg} / \mathrm{L}$ (provided as a baseline for comparison, site-specific TVS used for exceedance analysis); unfil, unfiltered; unsp, unspeciated; UT, Utah; UTDEQ, Utah Department of Environmental Quality; $\mu \mathrm{S} / \mathrm{cm}$, microsiemens per centimeter; <, less than; --, not available or not computed; 2B, secondary-contact recreation (UT); 3A, aquatic-life cold (UT); 3C, aquatic-life support (UT); 30d, 30-day average; III, chromium III; *, extreme outlier excluded; bold type indicates exceedance during recent POR]

\begin{tabular}{|c|c|c|c|c|c|c|c|}
\hline \multirow{2}{*}{$\begin{array}{l}\text { Selected } \\
\text { streams } \\
\text { (see fig. } 13 \text { for } \\
\text { location of } \\
\text { streams) }\end{array}$} & \multirow[b]{2}{*}{$\begin{array}{l}\text { Field property } \\
\text { or constituent } \\
\text { (reporting units) }\end{array}$} & \multicolumn{4}{|c|}{$\begin{array}{c}\text { Complete POR } \\
1947 \text { to } 2003^{1}\end{array}$} & \multicolumn{2}{|c|}{$\begin{array}{l}\text { Recent POR } \\
1988 \text { to } 2003\end{array}$} \\
\hline & & $\begin{array}{c}\text { No. of } \\
\text { analyses/No. } \\
\text { of censored } \\
\text { values }\end{array}$ & $\begin{array}{l}\text { Minimum } \\
\text { value }\end{array}$ & $\begin{array}{l}\text { Median } \\
\text { value }\end{array}$ & $\begin{array}{l}\text { Maximum } \\
\text { value }\end{array}$ & $\begin{array}{l}\text { UTDEQ or AZDEQ } \\
\text { standard or } \\
\text { Federal criteria } \\
(\text { Use })^{2}\end{array}$ & $\begin{array}{l}\text { No. of exceedances/ } \\
\text { No. of analyses/ } \\
\text { No. of sites with } \\
\text { exceedances (Use) }\end{array}$ \\
\hline
\end{tabular}

Trace elements (1971-2003)—Continued

(Results reported in micrograms per liter; zero values excluded except where able to recensor to censoring level)

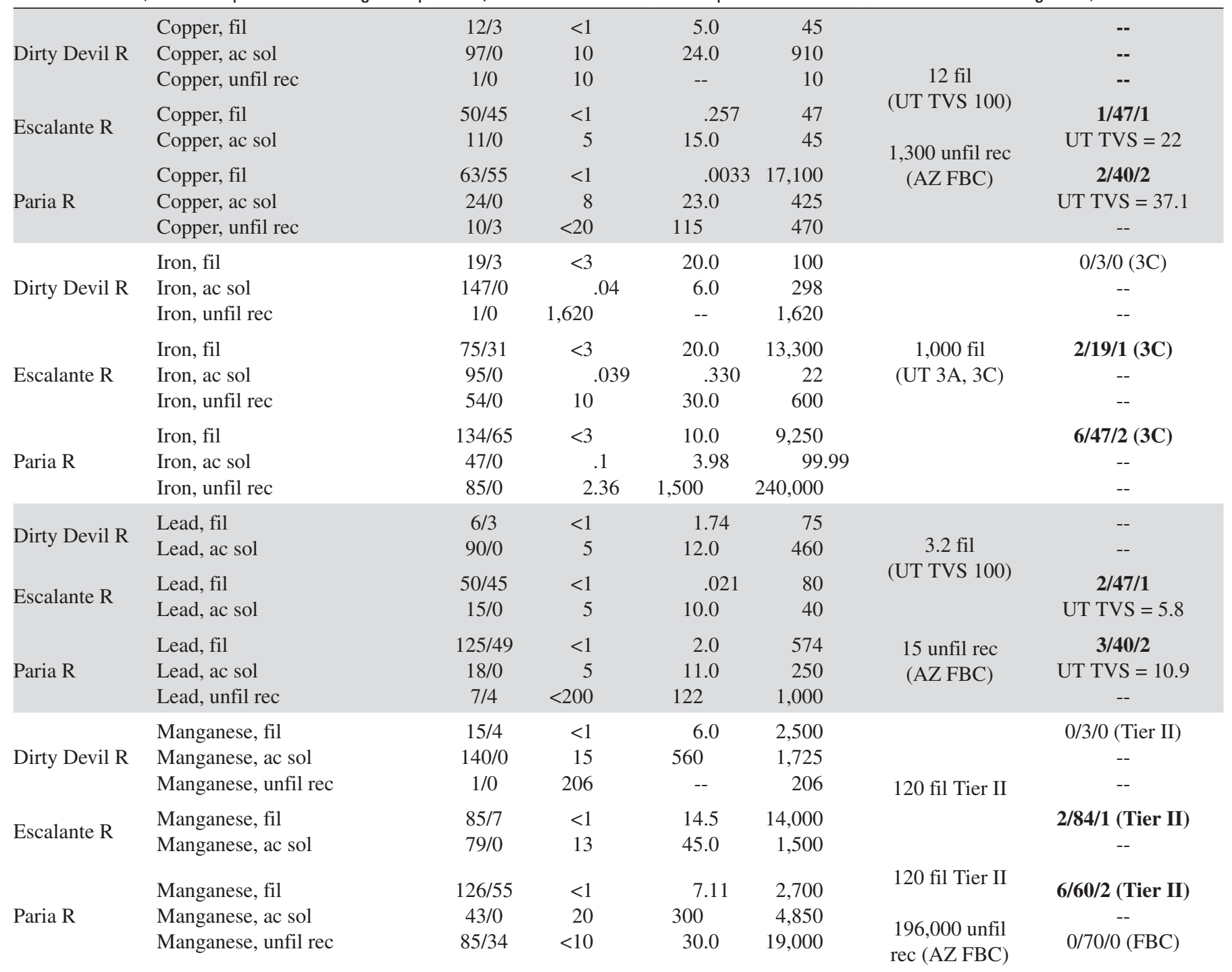


Table 20. Statistical summary of water-quality data and exceedances of water-quality standards for selected stream-sampling sites in the Dirty Devil, Escalante, and Paria Rivers located in and upstream from Glen Canyon National Recreation Area, Arizona and Utah, 1947 to 2003.-Continued

[ac sol, acid soluble; AWW, aquatic and wildlife warm water (AZ); AZ, Arizona; AZDEQ, Arizona Department of Environmental Quality; deg C, degrees Celsius; EPA RC III, U.S. Environmental Protection Agency National Recommended Nutrient Criteria for Ecoregion III; FBC, full-body contact (AZ); fil, filtered; H, high (maximum) standard; L, low (minimum) standard; mg/L, milligrams per liter; N, nitrogen; No., number; NTU, nephelometric turbidity units; P, phosphorus; POR, period of record; R, River; rec, recoverable; TVS, table value standard; TVS 100, table value standard computed at a hardness of $100 \mathrm{mg} / \mathrm{L}$ (provided as a baseline for comparison, site-specific TVS used for exceedance analysis); unfil, unfiltered; unsp, unspeciated; UT, Utah; UTDEQ, Utah Department of Environmental Quality; $\mu \mathrm{S} / \mathrm{cm}$, microsiemens per centimeter; <, less than; --, not available or not computed; 2B, secondary-contact recreation (UT); 3A, aquatic-life cold (UT); 3C, aquatic-life support (UT); 30d, 30-day average; III, chromium III; *, extreme outlier excluded; bold type indicates exceedance during recent POR]

\begin{tabular}{|c|c|c|c|c|c|c|c|}
\hline \multirow{2}{*}{$\begin{array}{l}\text { Selected } \\
\text { streams } \\
\text { (see fig. } 13 \text { for } \\
\text { location of } \\
\text { streams) }\end{array}$} & \multirow[b]{2}{*}{$\begin{array}{l}\text { Field property } \\
\text { or constituent } \\
\text { (reporting units) }\end{array}$} & \multicolumn{4}{|c|}{$\begin{array}{c}\text { Complete POR } \\
1947 \text { to } 2003^{1}\end{array}$} & \multicolumn{2}{|c|}{$\begin{array}{l}\text { Recent POR } \\
1988 \text { to } 2003\end{array}$} \\
\hline & & $\begin{array}{c}\text { No. of } \\
\text { analyses/No. } \\
\text { of censored } \\
\text { values }\end{array}$ & $\begin{array}{l}\text { Minimum } \\
\text { value }\end{array}$ & $\begin{array}{l}\text { Median } \\
\text { value }\end{array}$ & $\begin{array}{l}\text { Maximum } \\
\text { value }\end{array}$ & $\begin{array}{l}\text { UTDEQ or AZDEO } \\
\text { standard or } \\
\text { Federal criteria } \\
(\text { Use })^{2}\end{array}$ & $\begin{array}{l}\text { No. of exceedances/ } \\
\text { No. of analyses/ } \\
\text { No. of sites with } \\
\text { exceedances (Use) }\end{array}$ \\
\hline
\end{tabular}

Trace elements (1971-2003)—Continued

(Results reported in micrograms per liter; zero values excluded except where able to recensor to censoring level)

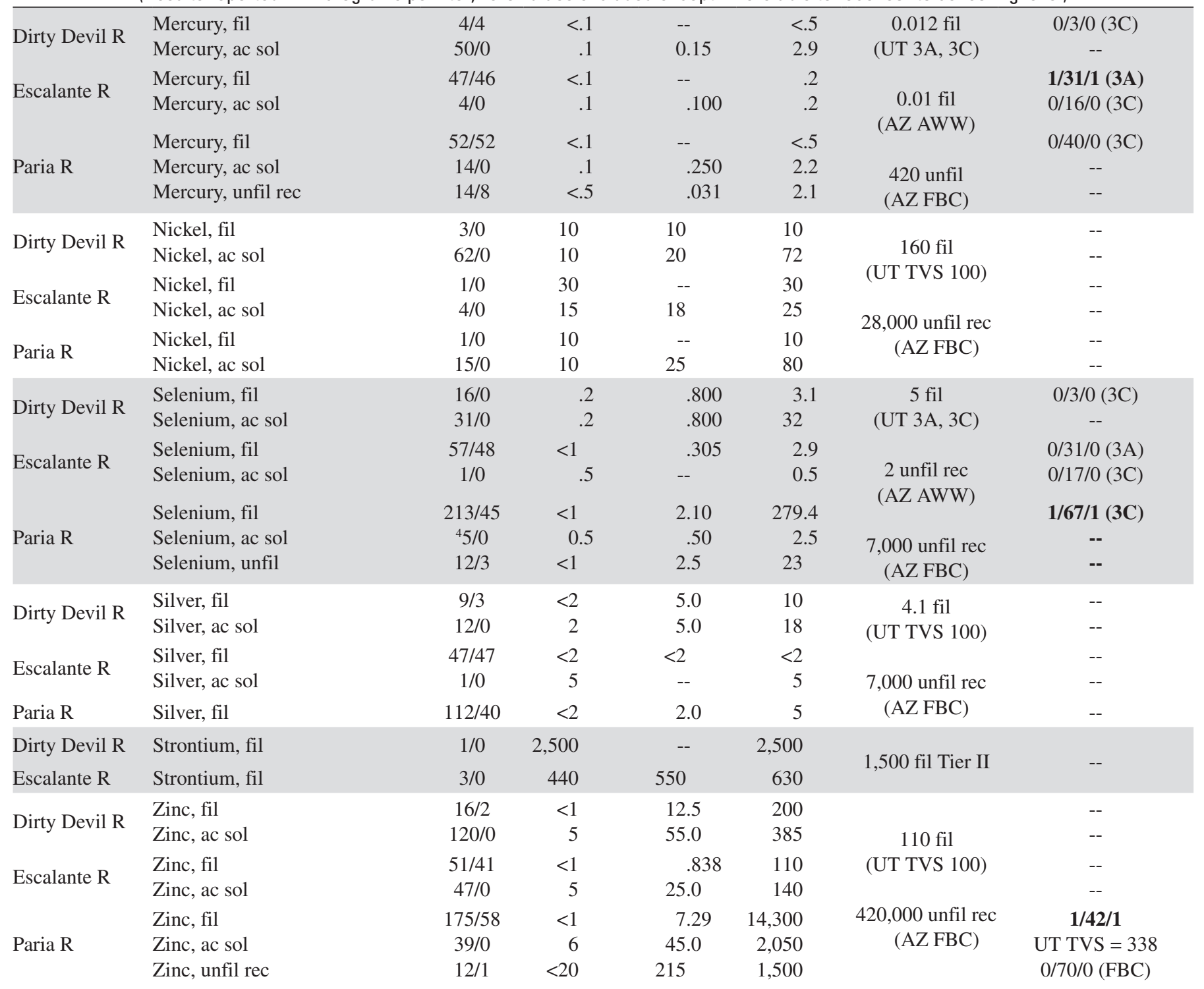


Table 20. Statistical summary of water-quality data and exceedances of water-quality standards for selected stream-sampling sites in the Dirty Devil, Escalante, and Paria Rivers located in and upstream from Glen Canyon National Recreation Area, Arizona and Utah, 1947 to 2003.-Continued

[ac sol, acid soluble; AWW, aquatic and wildlife warm water (AZ); AZ, Arizona; AZDEQ, Arizona Department of Environmental Quality; deg C, degrees Celsius; EPA RC III, U.S. Environmental Protection Agency National Recommended Nutrient Criteria for Ecoregion III; FBC, full-body contact (AZ); fil, filtered; H, high (maximum) standard; L, low (minimum) standard; mg/L, milligrams per liter; N, nitrogen; No., number; NTU, nephelometric turbidity units; P, phosphorus; POR, period of record; R, River; rec, recoverable; TVS, table value standard; TVS 100, table value standard computed at a hardness of $100 \mathrm{mg} / \mathrm{L}$ (provided as a baseline for comparison, site-specific TVS used for exceedance analysis); unfil, unfiltered; unsp, unspeciated; UT, Utah; UTDEQ, Utah Department of Environmental Quality; $\mu \mathrm{S} / \mathrm{cm}$, microsiemens per centimeter; <, less than; --, not available or not computed; 2B, secondary-contact recreation (UT); 3A, aquatic-life cold (UT); 3C, aquatic-life support (UT); 30d, 30-day average; III, chromium III; *, extreme outlier excluded; bold type indicates exceedance during recent POR]

\begin{tabular}{|c|c|c|c|c|c|c|c|}
\hline \multirow{2}{*}{$\begin{array}{l}\text { Selected } \\
\text { streams } \\
\text { (see fig. } 13 \text { for } \\
\text { location of } \\
\text { streams) }\end{array}$} & \multirow[b]{2}{*}{$\begin{array}{l}\text { Field property } \\
\text { or constituent } \\
\text { (reporting units) }\end{array}$} & \multicolumn{4}{|c|}{$\begin{array}{c}\text { Complete POR } \\
1947 \text { to } 2003^{1}\end{array}$} & \multicolumn{2}{|c|}{$\begin{array}{l}\text { Recent POR } \\
1988 \text { to } 2003 \\
\end{array}$} \\
\hline & & $\begin{array}{c}\text { No. of } \\
\text { analyses/No. } \\
\text { of censored } \\
\text { values }\end{array}$ & $\begin{array}{l}\text { Minimum } \\
\text { value }\end{array}$ & $\begin{array}{l}\text { Median } \\
\text { value }\end{array}$ & $\begin{array}{l}\text { Maximum } \\
\text { value }\end{array}$ & $\begin{array}{c}\text { UTDEQ or AZDEQ } \\
\text { standard or } \\
\text { Federal criteria } \\
(\text { Use })^{2}\end{array}$ & $\begin{array}{l}\text { No. of exceedances/ } \\
\text { No. of analyses/ } \\
\text { No. of sites with } \\
\text { exceedances (Use) }\end{array}$ \\
\hline
\end{tabular}

Radiological constituents (1975-1991) (Results reported in picocuries per liter)

\begin{tabular}{llccrcc}
\hline Dirty Devil R & Alpha radioactivity, fil & $5 / 0$ & 4 & 38 & 56 & -- \\
Escalante R & Alpha radioactivity, fil & $6 / 0$ & 2 & 3.0 & 7 & 15 (UT 3A, 3C) \\
Paria R & Alpha radioactivity, fil & $5 / 0$ & 2 & 23.0 & 35 & -- \\
Dirty Devil R & Beta radioactivity, unfil & $20 / 0$ & 0 & 20.5 & 761 & -- \\
Escalante R & Beta radioactivity, unfil & $11 / 0$ & 1 & 11.0 & 30 & 50 (UT 3A, 3C) \\
Paria R & Beta radioactivity, unfil & $7 / 0$ & 0 & 35.0 & 363 & -- \\
Dirty Devil R & Radium-226, unfil & $7 / 0$ & 0 & 2.0 & 770 & -- \\
Escalante R & Radium-226, unfil & $6 / 0$ & 0 & .250 & 2 & -- \\
Paria R & Radium-226, unfil & $6 / 0$ & 0 & 1.25 & 10 & -- \\
Dirty Devil R & Tritium, unfil & $14 / 0$ & 0 & 172.5 & 1,081 & -- \\
Escalante R & Tritium, unfil & $6 / 0$ & 1 & 42.5 & 500 & -- \\
Paria R & Tritium, unfil & $2 / 0$ & 86 & 293 & 500 & -- \\
\hline \multicolumn{1}{c}{ Peion }
\end{tabular}

${ }^{1}$ Period of record reflects full range evaluated for all relevant sites within this time period; some sites or constituents may not have had data available for the entire record. All available data considered; POR varies with constituent and site.

${ }^{2}$ State standards and designated beneficial uses from the State of Utah Department of Environmental Quality (all three rivers) and the Arizona Department of Environmental Quality (Paria River only) (State of Arizona, 2002; Utah Department of Environmental Quality, 2005). No hardness data available for Paria River sites in Arizona; therefore, no AZ TVS standards were evaluated. Selected Federal criteria are used when State standards are not established, including the USEPA National Recommended Nutrient Criteria for Ecoregions II and III (U.S. Environmental Protection Agency, 2002), the National Ambient Water Quality criteria (NAWQ), or the secondary chronic Tier II values (Suter and Tsao, 1996).

${ }^{3}$ Aggregated nutrients based on Mueller and others (1995); where sample fraction not stated, aggregation includes both filtered and unfiltered concentrations. Zero values were excluded unless converted to a value of less than the censoring level.

${ }^{4}$ Additional acid-soluble selenium result values of $0 \mu \mathrm{g} / \mathrm{L}$ were not considered for this summary as no censoring levels could be determined for these data, including 105 (Dirty Devil River), 85 (Escalante River), and 38 (Paria River) results. 
Table 21. Statistical summary of water-quality data and aquatic-life or secondary-contact recreation exceedances for evaluated tributaries that flow into the Escalante River or Lake Powell, Glen Canyon National Recreation Area, Utah, 1979 to 2003.

[min., minimum; chr, chronic; Cr, creek; Cyn, canyon; deg C, degrees Celsius; mg/L, milligrams per liter; P, phosphorus; POR, period of record; SU, standard units; T II, Tier II criteria; TVS, computed table value standard applicable to aquatic-life uses; W, wash; $\mu \mathrm{g} / \mathrm{L}$, micrograms per liter; $2 \mathrm{~B}$, secondary-contact recreation (Utah); 3B, aquatic-life warm (Utah); 3C, aquatic-life support (Utah); 30 dav, 30-day average; bold type indicates exceedance during recent POR; --, no data or not applicable]

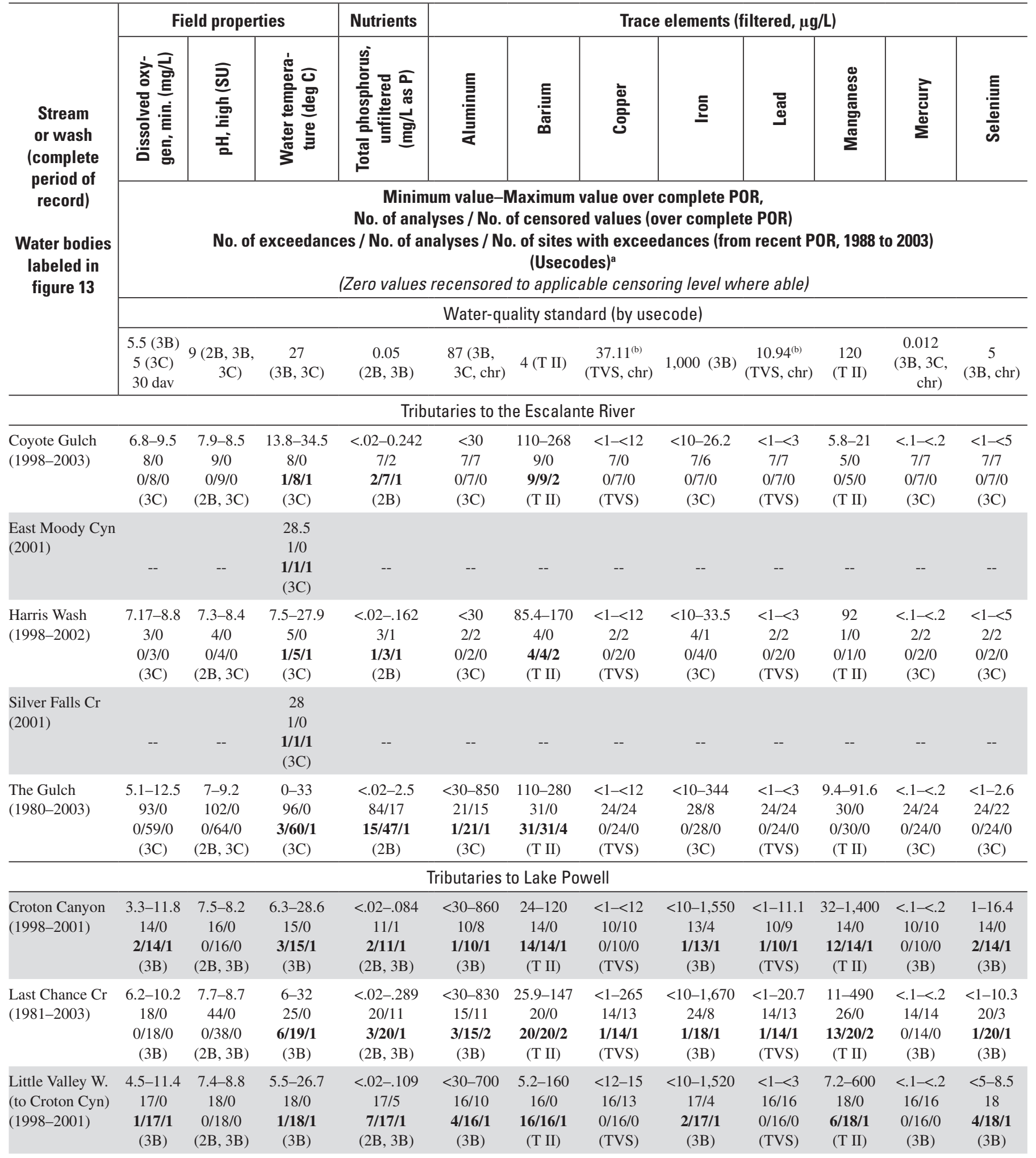


Table 21. Statistical summary of water-quality data and aquatic-life or secondary-contact recreation exceedances for evaluated tributaries that flow into the Escalante River or Lake Powell, Glen Canyon National Recreation Area, Utah, 1979 to 2003.

[min., minimum; chr, chronic; Cr, creek; Cyn, canyon; deg C, degrees Celsius; mg/L, milligrams per liter; P, phosphorus; POR, period of record; SU, standard units; T II, Tier II criteria; TVS, computed table value standard applicable to aquatic-life uses; $\mathrm{W}$, wash; $\mu \mathrm{g} / \mathrm{L}$, micrograms per liter; $2 \mathrm{~B}$, secondary-contact recreation (Utah); 3B, aquatic-life warm (Utah); 3C, aquatic-life support (Utah); 30 dav, 30-day average; bold type indicates exceedance during recent POR; --, no data or not applicable]

\begin{tabular}{|c|c|c|c|c|c|c|c|c|c|c|c|c|}
\hline \multirow{2}{*}{$\begin{array}{c}\text { Stream } \\
\text { or wash } \\
\text { (complete } \\
\text { period of } \\
\text { record) } \\
\text { Water bodies } \\
\text { labeled in } \\
\text { figure } 13\end{array}$} & \multicolumn{3}{|c|}{ Field properties } & 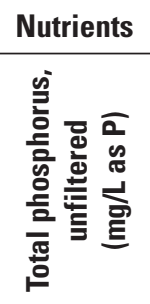 & \multicolumn{8}{|c|}{ Trace elements (filtered, $\mu \mathrm{g} / \mathrm{L}$ ) } \\
\hline & \multicolumn{12}{|c|}{ Water-quality standard (by usecode) } \\
\hline \multicolumn{13}{|c|}{ Tributaries to Lake Powell—Continued } \\
\hline $\begin{array}{l}\text { North Wash } \\
\text { (1997-1998) }\end{array}$ & $\begin{array}{c}7.21-11.4 \\
16 / 0 \\
0 / 16 / 0 \\
(3 B)\end{array}$ & $\begin{array}{c}8.1-8.8 \\
16 / 0 \\
0 / 16 / 0 \\
(2 \mathrm{~B}, 3 \mathrm{~B})\end{array}$ & $\begin{array}{c}3.96-27.7 \\
16 / 0 \\
\mathbf{2 / 1 6 / 1} \\
(3 \mathrm{~B})\end{array}$ & $\begin{array}{c}<0.02-0.02 \\
10 / 8 \\
0 / 10 / 0 \\
(2 \mathrm{~B}, 3 \mathrm{~B})\end{array}$ & $\begin{array}{c}<30 \\
5 / 5 \\
0 / 5 / 0 \\
(3 \mathrm{~B})\end{array}$ & $\begin{array}{c}110-130 \\
5 / 0 \\
\mathbf{5 / 5} / \mathbf{2} \\
(\mathrm{T} \mathrm{II})\end{array}$ & $\begin{array}{c}<1-<10 \\
5 / 5 \\
0 / 5 / 0 \\
\text { (TVS) }\end{array}$ & $\begin{array}{c}<3-<10 \\
5 / 5 \\
0 / 5 / 0 \\
(3 \mathrm{~B})\end{array}$ & $\begin{array}{c}<1 \\
5 / 5 \\
0 / 5 / 0 \\
(\mathrm{TVS})\end{array}$ & $\begin{array}{c}5.6-29 \\
5 / 0 \\
0 / 5 / 0 \\
\text { (T II) }\end{array}$ & $\begin{array}{c}<0.1 \\
5 / 5 \\
0 / 5 / 0 \\
(3 \mathrm{~B})\end{array}$ & $\begin{array}{c}1.2-1.5 \\
5 / 0 \\
0 / 5 / 0 \\
(3 \mathrm{~B})\end{array}$ \\
\hline $\begin{array}{l}\text { Tibbet Canyon } \\
\text { (to Warm Cr) } \\
(1998-2002)\end{array}$ & $\begin{array}{c}1.9-9.1 \\
4 / 0 \\
\mathbf{3 / 4} \mathbf{1} \\
(3 \mathrm{~B})\end{array}$ & $\begin{array}{c}7.2-9.4 \\
5 / 0 \\
\mathbf{1} / \mathbf{5} / \mathbf{1} \\
(2 \mathrm{~B}, 3 \mathrm{~B})\end{array}$ & $\begin{array}{c}27.6-32.2 \\
4 / 0 \\
\mathbf{4 / 4 / 1} \\
(3 \mathrm{~B})\end{array}$ & $\begin{array}{c}.027-.069 \\
4 / 0 \\
\mathbf{2 / 4} / \mathbf{1} \\
(2 \mathrm{~B}, 3 \mathrm{~B})\end{array}$ & $\begin{array}{c}63-1,100 \\
3 / 0 \\
\mathbf{1 / 3} / \mathbf{1} \\
(3 \mathrm{~B})\end{array}$ & $\begin{array}{c}22-55.7 \\
4 / 0 \\
\mathbf{4} / \mathbf{4} / \mathbf{1} \\
\text { (T II) }\end{array}$ & $\begin{array}{c}<1-<12 \\
3 / 3 \\
0 / 3 / 0 \\
(\text { TVS })\end{array}$ & $\begin{array}{c}33.1-1,530 \\
3 / 0 \\
\mathbf{1 / 3} / \mathbf{1} \\
(3 \mathrm{~B})\end{array}$ & $\begin{array}{c}<1-<3 \\
3 / 3 \\
0 / 3 / 0 \\
(\text { TVS })\end{array}$ & $\begin{array}{c}7.6-35.4 \\
3 / 0 \\
0 / 3 / 0 \\
\text { (T II) }\end{array}$ & $\begin{array}{c}<.1-<.2 \\
3 / 3 \\
0 / 3 / 0 \\
(3 \mathrm{~B})\end{array}$ & $\begin{array}{c}<5-1.6 \\
3 / 1 \\
0 / 3 / 0 \\
(3 \mathrm{~B})\end{array}$ \\
\hline $\begin{array}{l}\text { Trachyte Creek } \\
\text { (1987-1998) }\end{array}$ & $\begin{array}{c}6.2-13 \\
17 / 0 \\
0 / 16 / 0 \\
(3 \mathrm{~B})\end{array}$ & $\begin{array}{c}7.8-10 \\
17 / 0 \\
\mathbf{1 / 1 6} \mathbf{1} \\
(2 \mathrm{~B}, 3 \mathrm{~B})\end{array}$ & $\begin{array}{c}4.68-27 \\
17 / 0 \\
0 / 16 / 0 \\
(3 \mathrm{~B})\end{array}$ & $\begin{array}{c}<.02-.78 \\
14 / 3 \\
\mathbf{6} / \mathbf{1 3} / \mathbf{1} \\
(2 \mathrm{~B}, 3 \mathrm{~B})\end{array}$ & $\begin{array}{c}<30-57 \\
3 / 2 \\
0 / 3 / 0 \\
(3 \mathrm{~B})\end{array}$ & $\begin{array}{c}15-66 \\
5 / 0 \\
\mathbf{5 / 5 / 1} \\
(\mathrm{T} \mathrm{II})\end{array}$ & $\begin{array}{c}<1-<10 \\
5 / 5 \\
0 / 5 / 0 \\
(\text { TVS })\end{array}$ & $\begin{array}{c}<3-50 \\
5 / 2 \\
0 / 5 / 0 \\
(3 \mathrm{~B})\end{array}$ & $\begin{array}{c}<1-<10 \\
5 / 5 \\
0 / 5 / 0 \\
(\text { TVS })\end{array}$ & $\begin{array}{c}11-160 \\
3 / 0 \\
\mathbf{1 / 3 / 1} \\
(\mathrm{T} \mathrm{II})\end{array}$ & $\begin{array}{c}<.1 \\
5 / 5 \\
0 / 5 / 0 \\
(3 \mathrm{~B})\end{array}$ & $\begin{array}{c}<1-4.9 \\
5 / 2 \\
0 / 5 / 0 \\
(3 \mathrm{~B})\end{array}$ \\
\hline $\begin{array}{l}\text { White Canyon } \\
\text { Creek } \\
(1979-1997)\end{array}$ & $\begin{array}{c}7.1-9.5 \\
6 / 0 \\
0 / 3 / 0 \\
(3 \mathrm{~B})\end{array}$ & $\begin{array}{c}8-8.7 \\
6 / 0 \\
0 / 3 / 0 \\
(2 \mathrm{~B}, 3 \mathrm{~B})\end{array}$ & $\begin{array}{c}15-24.8 \\
6 / 0 \\
0 / 3 / 0 \\
(3 \mathrm{~B})\end{array}$ & $\begin{array}{c}<.02-.85 \\
3 / 1^{\mathrm{c}} \\
-- \\
(2 \mathrm{~B}, 3 \mathrm{~B})\end{array}$ & $\begin{array}{c}160 \\
1 / 0 \\
\mathbf{1 / 1} / \mathbf{1} \\
(3 \mathrm{~B})\end{array}$ & $\begin{array}{c}120-170 \\
2 / 0 \\
2 / 2 / 2 \\
\text { (T II) }\end{array}$ & $\begin{array}{c}<2-15 \\
3 / 2 \\
0 / 1 / 0 \\
(\text { TVS) }\end{array}$ & $\begin{array}{c}<10-60.4 \\
3 / 2 \\
0 / 1 / 0 \\
(3 \mathrm{~B})\end{array}$ & $\begin{array}{c}<1-<2 \\
3 / 3 \\
0 / 1 / 0 \\
(\text { TVS })\end{array}$ & -- & $\begin{array}{c}<.1 \\
1 / 1 \\
0 / 1 / 0 \\
(3 \mathrm{~B})\end{array}$ & $\begin{array}{c}<1 \\
3 / 3 \\
0 / 1 / 0 \\
(3 \mathrm{~B})\end{array}$ \\
\hline
\end{tabular}

${ }^{a}$ State standards and designated beneficial uses from the State of Utah Department of Environmental Quality (Utah Department of Environmental Quality, 2005). Selected Federal criteria are used when State standards are not established, including the USEPA National Recommended Nutrient Criteria for Ecoregions II and III (U.S. Environmental Protection Agency, 2002), the National Ambient Water Quality criteria (NAWQ), or the secondary chronic Tier II values (Suter and Tsao, 1996).

${ }^{\mathrm{b}}$ TVS values are the same for these sites because measured hardness exceeded $400 \mathrm{mg} / \mathrm{L}$ as $\mathrm{CaCO}_{3}$ for each of these sites. This is the maximum value used for TVS calculations.

c All data collected before 1988. 
not summarized as part of the standards exceedance analysis, exceeded this standard in all three rivers. Two of the evaluated tributaries, Tibbet Canyon and Trachyte Creek, each exceeded the aquatic-life warm and secondary-contact recreation standard of 9 SU for one value out of 21 measurements.

Specific-conductance measurements were high in the Dirty Devil, Escalante, and Paria Rivers (maximum values ranging from 4,350 to $5,270 \mu \mathrm{S} / \mathrm{cm}$ ); however, no standards exist in Utah or Arizona for SC. Generally, SC values were lower in the Escalante River (median value $685 \mu \mathrm{S} / \mathrm{cm}$ ) than in the Dirty Devil or Paria Rivers, which had median values of 1,800 and $1,320 \mu \mathrm{S} / \mathrm{cm}$, respectively.

Turbidity values were high in measurements from all three perennial rivers and exceeded the Utah and Arizona standards, which ranged from 10 to 50 NTU, numerous times. The maximum turbidity values ranged from 8,390 (Dirty Devil River) to 18,420 (Escalante River), to a high of 54,380 NTU (Paria River), though the median values indicate that generally the Escalante River had the lowest turbidity of the three rivers. Elevated turbidity values can result from erosion, stream channel downcutting, and other sources that can increase suspended solids. Higher turbidity levels corresponded to higher discharge for these rivers.

Measurements of water temperature exceeded the Utah standard for aquatic-life support $\left(27^{\circ} \mathrm{C}\right)$ between 1 and 17 times in all three rivers at five sites (sites 3014, 3651, 3816, 3818 , and 3958). The aquatic-life cold-water standard of $20^{\circ} \mathrm{C}$ was exceeded 29 times in the Escalante River at three sites (sites 3653, 3882, and 3901). Upstream from the park, the Escalante River from Boulder Creek confluence to the North Creek confluence was listed in the Utah 2002 303(d) list for exceeding the cold-water fishery temperature criteria; however, the Escalante River Watershed Water-Quality Management Plan suggested that historical water-quality data had not been collected to target the maximum daily water temperature or the critical season and that new data, collected in 2003, was to be used for the TMDL analysis (Millennium Science \& Engineering, Inc., 2005). Maximum water temperature values ranged from 30 to $39^{\circ} \mathrm{C}$ and were generally higher in the Paria River (median temperature of $16^{\circ} \mathrm{C}$ ) than the other two rivers (median temperatures between 10.5 and $11.5^{\circ} \mathrm{C}$ ). Water temperature standards for aquatic-life warm-water or aquatic-life support were exceeded between one and eight times in measurements made in all but three of the evaluated tributaries, and maximum values ranged from 26.7 to $34.5^{\circ} \mathrm{C}$. Water temperature and DO are inversely related; as temperatures rise in these rivers, the DO concentrations fall.

\section{Major lons}

The predominant geologic formation in the area of the Dirty Devil, Escalante, and Paria Rivers is the Glen Canyon Group (including the Navajo Sandstone, Kayenta Formation, and Wingate Sandstone). Within the Glen Canyon Group, mineral content varies and can result in variable water-type characterization. Water samples from the Paria and Dirty Devil Rivers are similar in major ion content and can be described as a calcium and sulfate water type with some magnesium, sodium, and chloride (fig. 16). Water samples from the Escalante River are a calcium, magnesium, and bicarbonate water type with some sulfate and chloride. Anion data from the 14 evaluated tributaries were insufficient to identify the water type.

\section{Nutrients}

Samples analyzed for nutrients, including ammonia (unfiltered and un-ionized), nitrate (unfiltered and filtered), total nitrogen (unfiltered), orthophosphorus, and total phosphorus (unfiltered), were collected between 1 and 203 times from 24 sites in the Dirty Devil, Escalante, and Paria Rivers. No recent data exceeded the chronic aquatic-life standards for unfiltered ammonia in Utah based on available water temperature, $\mathrm{pH}$, and unfiltered ammonia values, though much of the data lacked one or more of these values. No unfiltered ammonia data were available for the Arizona section of the Paria River. Nitrate concentrations did not exceed the applicable Utah or Arizona standards in the recent or historical data. Othophosphorus is not regulated in Utah or Arizona, and values are substantially less than the total phosphorus concentrations. Concentrations of total nitrogen and total phosphorus were elevated.

The USEPA-recommended nutrient criterion of $0.38 \mathrm{mg} / \mathrm{L}$ for total nitrogen in rivers and streams in Ecoregion III, which includes GLCA, was exceeded (since 1988) five times in analyses of samples from site 3882 in the Escalante River (U.S. Environmental Protection Agency, 2002). However, the median total nitrogen values for the Dirty Devil and Paria Rivers also exceeded this criterion based on all 70 and 43 historical analyses of samples, respectively. The highest historical values measured in these three rivers (all over $10 \mathrm{mg} / \mathrm{L}$ ) were in analyses of samples collected in 1977, 1984, and 1985. Of the 14 evaluated tributaries, one value from The Gulch $(0.436 \mathrm{mg} / \mathrm{L}$, site 3868$)$ and one value from Trachyte Creek (0.614 mg/L, site 3903) exceeded the 0.38-mg/L recommended level. Currently (2007), Utah and Arizona have no water-quality standard for total nitrogen.

Utah's secondary-contact recreation stream standard for total phosphorus (unfiltered) of $0.05 \mathrm{mg} / \mathrm{L}$ was exceeded in analyses of samples from all three rivers between 2 and 97 times at nine sites (sites 3888, 3014, 3755, 3882, 3901, 3816, 3817,3818 , and 3958). The Paria River had the most frequent exceedances; 97 out of 140 values (69 percent) exceeded this criterion. Only three analyses of samples (of which two exceeded the standard) collected from the Dirty Devil River since 1988 were available for exceedance analysis. Ten of the 14 evaluated tributaries indicate one or more total phosphorus (unfiltered) exceedances (48 exceedances total) out of 204 analyses of samples (table 21). The Gulch and Wahweap Creek had the largest number of exceedances (15 and 9 


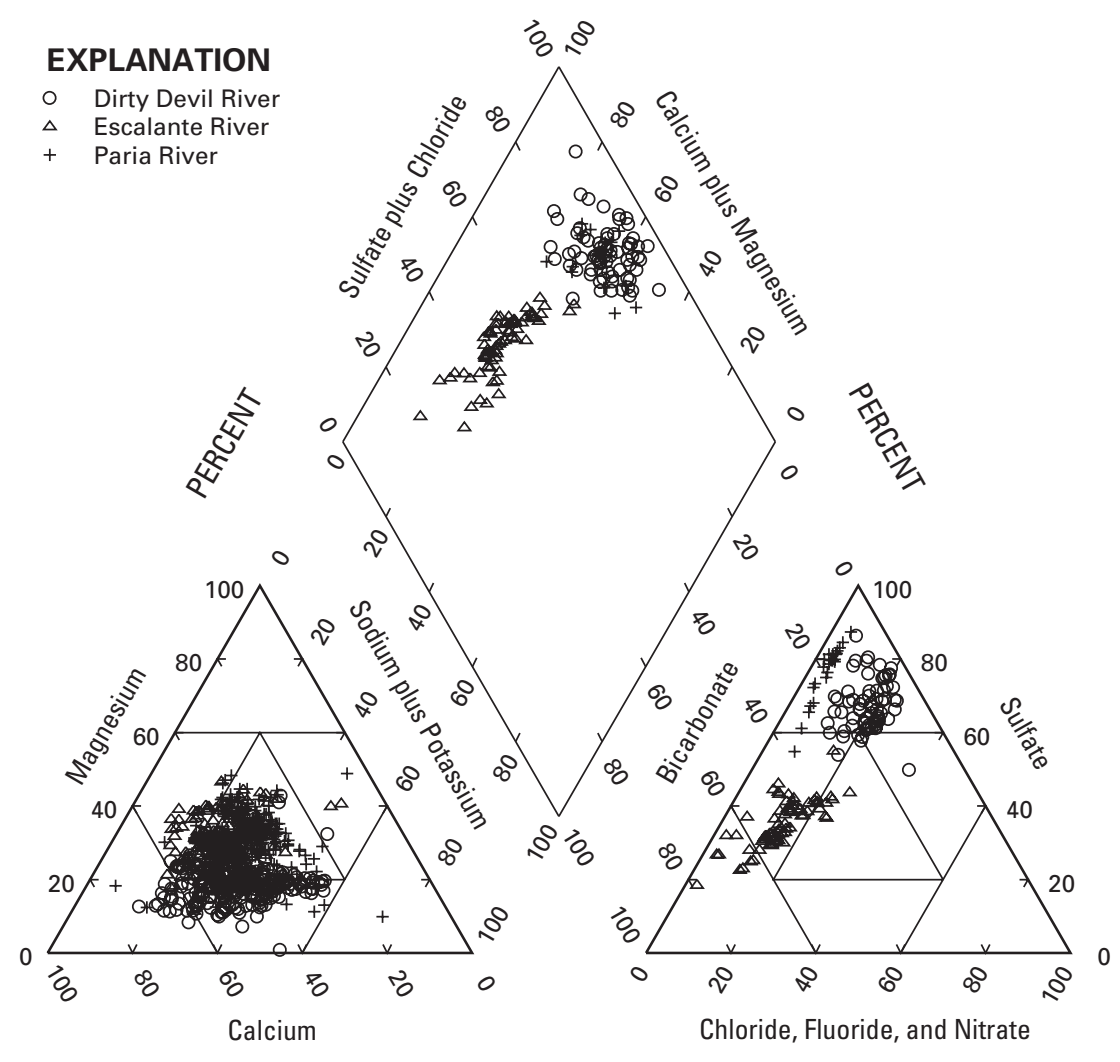

PERCENTAGE OF TOTAL MILLIEQUIVALENTS PER LITER

Figure 16. Water types of the Dirty Devil, Escalante, and Paria Rivers, Glen Canyon National Recreation Area, Arizona and Utah, 1947 to 2003.

exceedances, respectively). Currently (2007), Arizona has no water-quality standard for total phosphorus.

Elevated nutrient concentrations, particularly total nitrogen and phosphorus, could be the result of grazing activities in the riparian areas, atmospheric deposition (nitrogen), agricultural runoff in the upland areas, soil erosion, weathering of nitrogen- or phosphorus-rich bedrock materials, and residential development along riparian areas upstream from the park contributing septic or wastewater to the rivers (Holloway and Dahlgren, 2002; Gardner, 1990; Chapman, 1998; Paerl, 1997). Elevated nutrient levels may lead to eutrophication in the rivers or receiving waters (for example, Lake Powell) resulting in reduced water clarity and dissolved oxygen concentrations, species composition changes, and potentially harmful algal blooms (U.S. Environmental Protection Agency, 2001; Galloway and others, 2003).

\section{Trace Elements}

Current (2007) Utah and Arizona water-quality criteria for (chronic) aquatic life or full-body contact were used to evaluate recent trace-element data for the Dirty Devil, Escalante, and Paria Rivers for 16 trace elements (table 20).
Additionally, results for analyses of barium and manganese in samples collected in Utah were evaluated using the Federal Tier II criteria as no aquatic-life or recreational-contact standards are established for these constituents in Utah.

For the trace element concentrations evaluated using the Utah State standards, one or more exceedances in the Escalante or Paria Rivers were identified for filtered aluminum, cadmium, copper, iron, lead, mercury, selenium, and zinc. No trace-element exceedances of Utah State standards were identified in the Dirty Devil River based on analysis of recent (since 1988) data; however, there were only two sites on the Dirty Devil River with hardness data available for TVS computations, and of these, analyses of only three samples were available for standard exceedance analysis. Of the 14 evaluated tributaries, 7 had one or more exceedance of the Utah State standards for unfiltered aluminum, copper, iron, lead, mercury, or selenium (table 21).

Thirteen (5 on the Escalante River from sites 3014 and 3901, and 8 on the Paria River from sites 3816 and 3958) out of 95 recent analyses of samples for filtered aluminum exceeded the Utah chronic aquatic-life 87- $\mu \mathrm{g} / \mathrm{L}$ standard with elevated concentrations ranging from 160 to $7,200 \mu \mathrm{g} / \mathrm{L}$ 
(table 20). Additionally, two concentrations on the Escalante River, measured at 7,200 and 2,700 $\mu \mathrm{g} / \mathrm{L}$ in September 1999 and February 2000, respectively, and four concentrations on the Paria River ranging from 1,840 to 3,600 $\mu \mathrm{g} / \mathrm{L}$, measured in August or September 1998 or February 2003, exceeded the higher acute standard of $750 \mu \mathrm{g} / \mathrm{L}$. Seven of the 14 evaluated tributaries had between one and four aluminum exceedances and analyses of samples from four of these sites also exceeded the higher acute standard. Exceedances from the evaluated tributaries ranged in concentration from 94 to $1,100 \mu \mathrm{g} / \mathrm{L}$. Aluminum can pass through standard $0.45-\mu \mathrm{m}$ pore filters in colloidal form, which could result in misleadingly high filtered aluminum concentrations (Hem, 1989; Sposito, 1996).

For the trace element data evaluated using the Arizona State standards, analyses of samples from the Paria River exceeded the filtered beryllium aquatic and wildlife warm-water standard of $5.3 \mu \mathrm{g} / \mathrm{L}$ six times (from sites 3725 , 3726,3727 , and 3728 ) out of 70 samples. These six values ranged from 5.8 to $38.4 \mu \mathrm{g} / \mathrm{L}$.

Filtered cadmium exceeded the Utah calculated sitespecific TVS of $1.8 \mu \mathrm{g} / \mathrm{L}$, based on an average hardness value of $217 \mathrm{mg} / \mathrm{L}$ and a maximum concentration of $3.1 \mu \mathrm{g} / \mathrm{L}$, in one analysis from 47 samples collected from site 3014 on the Escalante River. There are many sources of cadmium in the environment, including atmospheric from volatilization of cadmium through fossil fuel combustion and metallurgical processing (Hem, 1989).

The Escalante River had one exceedance (out of 47 analyses of samples) from site 3014 and the Paria River had two exceedances, one exceedance each (out of 40 analyses of samples) from sites 3816 and 3958, of their filtered copper TVS of 22 and $37.1 \mu \mathrm{g} / \mathrm{L}$, respectively. Copper was exceeded twice in analyses of samples from the evaluated tributaries: once in Last Chance Creek with a value of $265 \mu \mathrm{g} / \mathrm{L}$ and a TVS of $37.1 \mu \mathrm{g} / \mathrm{L}$ and once in Wahweap Creek with a value of $508 \mu \mathrm{g} / \mathrm{L}$ and a TVS of $37.1 \mu \mathrm{g} / \mathrm{L}$, based on a hardness of $400 \mathrm{mg} / \mathrm{L}$.

Filtered iron concentrations exceeded the $1,000-\mu \mathrm{g} / \mathrm{L}$ aquatic-life cold-water and aquatic-life support standards twice from site 3014 (out of 19 analyses of samples) in the Escalante River and six times from sites 3816 and 3958 (out of 47 analyses of samples) in the Paria River. These exceedance concentrations ranged from 1,220 to $13,300 \mu \mathrm{g} / \mathrm{L}$; no relation existed between these elevated values and flow. Iron was exceeded once each in samples from 4 of the 14 evaluated tributaries (Croton Canyon, Last Chance Creek, Tibbet Canyon, and Wahweap Creek) and twice in samples from Little Valley Wash (table 21). Exceedance concentrations in the tributaries ranged from 1,010 to $1,670 \mu \mathrm{g} / \mathrm{L}$.

Filtered lead concentrations exceeded the TVS of $5.8 \mu \mathrm{g} / \mathrm{L}$ twice out of 47 analyses of samples from the Escalante River (from site 3014) and the TVS of $10.9 \mu \mathrm{g} / \mathrm{L}$ three times out of 40 analyses of samples collected from the Paria River (from sites 3816 and 3958). Samples from the Paria River exceeded the computed acute TVS of $281 \mu \mathrm{g} / \mathrm{L}$ with one measured value of $574 \mu \mathrm{g} / \mathrm{L}$. For the evaluated tributaries, analyses of samples from Croton Canyon, Last Chance Creek, and Wahweap Creek each had one exceedance of their computed chronic TVS (10.94 $\mu \mathrm{g} / \mathrm{L}$ for all three) for filtered lead.

One exceedance of the filtered mercury standard of $0.012 \mu \mathrm{g} / \mathrm{L}$ in the Escalante River from site 3882 (out of 31 analyses of samples) and one in Wahweap Creek from site 3956 (out of 13 analyses of samples) occurred in the data collected since 1988; these exceedance concentrations were 0.200 and $0.264 \mu \mathrm{g} / \mathrm{L}$, respectively. Filtered mercury was not detected in the Dirty Devil River (out of 4 analyses of samples) or in the Paria River (out of 52 analyses of samples).

One exceedance of the filtered selenium standard occurred from site 3816 in the Paria River (out of 67 recent analyses of samples); the value was $5.1 \mu \mathrm{g} / \mathrm{L}$, which is only slightly higher than the Utah chronic standard of $5 \mu \mathrm{g} / \mathrm{L}$. For the Paria River sites in Arizona, a chronic standard for unfiltered recoverable selenium applies to aquatic warm-water ( $2 \mu \mathrm{g} / \mathrm{L})$, full-body contact $(7,000 \mu \mathrm{g} / \mathrm{L})$, and fish consumption $(9,000 \mu \mathrm{g} / \mathrm{L})$ uses; however, no recent data (since 1998) exist for unfiltered or unfiltered recoverable selenium analyzed in samples collected from these sites. There are no unfiltered recoverable selenium data from the Arizona section of the Paria River. However, 35 filtered selenium values ranging from 6 to $279.4 \mu \mathrm{g} / \mathrm{L}$ (out of 70 samples collected since 1988) from the Arizona section of the Paria River exceeded the $2-\mu \mathrm{g} / \mathrm{L}$ Arizona standard for unfiltered recoverable selenium for an aquatic warm-water fishery indicating elevated selenium concentrations in this section of the Paria River (not shown in table 20). In the 14 evaluated tributaries, eight exceedances in four water bodies that all flow into Lake Powell (Croton Canyon, Last Chance Creek, Little Valley Wash, and Wahweap Creek) were identified with exceedance concentrations ranging from 5.13 to $16.4 \mu \mathrm{g} / \mathrm{L}$. Croton Canyon also had the two highest measured concentrations of unfiltered selenium.

In the Paria River, one value from the analyses of 42 samples collected since 1988 for filtered zinc exceeded the TVS of $338 \mu \mathrm{g} / \mathrm{L}$ from site 3958 with a value of $14,300 \mu \mathrm{g} / \mathrm{L}$; however, the median filtered zinc concentration for the Paria (based on 175 analyses of samples) is $7.29 \mu \mathrm{g} / \mathrm{L}$, which is lower than the calculated standard. None of the 14 tributaries evaluated had zinc exceedances.

For detected trace elements without Utah or Arizona (Paria River only) numeric aquatic-life standards or TVS, the concentrations were compared to the chronic NAWQ criteria or the secondary chronic Tier II values, as presented by Suter and Tsao (1996), as toxicological benchmarks useful for screening constituents for aquatic effects. Concentrations of filtered barium, manganese, and strontium were evaluated using this approach. Recent analyses of samples for barium and manganese had concentrations greater than the applicable Tier II values and were identified as constituents of possible ecological concern (tables 20 and 21). Barium exceeded the Tier II criterion of $4 \mu \mathrm{g} / \mathrm{L}$ in all recent analyses of samples collected from the Dirty Devil, Escalante, and Paria Rivers, in three of the five evaluated tributaries flowing into the 
Escalante River, and in all nine of the evaluated tributaries flowing into Lake Powell. Concentrations of manganese exceeded the Tier II criterion of $120 \mu \mathrm{g} / \mathrm{L}$ between two and six times in analyses of recent samples collected from the Escalante and Paria Rivers and from six of the nine evaluated tributaries that flow into Lake Powell.

\section{Organic, Pesticide, and Wastewater Compounds}

Sampling for analyses of organic and wastewater compounds was limited in the Dirty Devil, Escalante, and Paria Rivers. Before 1980, the surfactant methylene blue active substance was the only wastewater compound analyzed in samples from the Dirty Devil River, and results ranged from nondetect to $0.03 \mu \mathrm{g} / \mathrm{L}$. Two additional water samples were analyzed in 1983 in the Dirty Devil and one in 1979 in the Paria River; both of these were nondetect. Oil and grease in unfiltered water samples were analyzed in 1980, 1983, and 1984 in the Dirty Devil River with results ranging from 0.2 to $4 \mu \mathrm{g} / \mathrm{L}$ and once in 1983 in the Escalante River with a result of $8 \mu \mathrm{g} / \mathrm{L}$.

Eighteen water samples were collected and analyzed for one or more pesticides (more than 100 total pesticide compounds) between 1985 and 1987 from the Dirty Devil and Paria Rivers and from 1985 to 1991 and in 2002 from the Escalante River. Most of these results were nondetect. Three analyses of samples from the Escalante River and two from the Paria River had pesticide concentrations measured above the censoring level for one or more compounds (15 total compounds identified). The compounds with values above censoring levels are listed in table 22. No sediment or fishtissue samples were collected and analyzed concurrently with these water samples.

\section{Radiological Constituents}

Few data for radionuclides are available and were collected from 1975 through 1991 from the Dirty Devil, Escalante, and Paria Rivers. Samples from all three perennial rivers were analyzed for alpha and beta radioactivity, radium-226, and tritium between 2 and 20 times (table 20). No exceedances were identified in the data collected since 1988 for alpha and beta radioactivity, which have standards of 15 and $50 \mathrm{pCi} / \mathrm{L}$, respectively, in Utah; however, historical values measured prior to 1988 in samples from the Dirty Devil and the Paria Rivers exceeded these standards. Radiological constituents were not analyzed in samples from the 14 evaluated tributaries. Historical elevated concentrations could be the result of naturally occurring radionuclides from the area geology or from atmospheric deposition.

\section{Summary of Surface-Water Characterization and Considerations for Monitoring}

Historical and recently collected water-quality data from the Dirty Devil, Escalante, and Paria Rivers flowing in and through GLCA were evaluated and summarized according to data availability and compared to Utah and Arizona (selected sections of the Paria River only) numeric aquatic-life or recreation standards.

Very few data collected before 1973 are available and most of these data are for one site on the Escalante River. A noticeable decline in water-quality data-collection activities occurred from 1983 through 1996, after which time datacollection activities increased. Data for concentrations of radiological constituents and organic compounds are few and dated. Generally, water-quality data are lacking for tributaries to the perennial rivers in GLCA and for ephemeral or intermittent tributaries and washes flowing directly into Lake Powell. Future monitoring plans would benefit from addressing these data gaps.

During the recent period of record for the three rivers, frequent exceedances of water-quality standards or criteria by values of field properties and nutrient concentrations (greater than 25 percent) include low DO in the Arizona section of the Paria River, high turbidity in all three rivers, elevated unfiltered phosphorus in all three rivers, and elevated unfiltered nitrogen in the Escalante River. Low DO also was measured in the Escalante River 5 percent of the time during the recent period of record. Water temperature measurements in the Escalante and Paria Rivers exceeded selected beneficial use criteria 19 and 15 percent of the time, respectively, during the recent period of record. During this time, from measurements made in the 14 evaluated tributaries, DO standards were exceeded between one and three times in Croton Canyon, Little Valley Wash, Tibbet Canyon, Wahweap Creek, and Wesses Canyon; pH standards were exceeded once each in Tibbet Canyon and Trachyte Creek; and water temperature standards were exceeded between one and eight times in all but three of the evaluated tributaries. The standard for unfiltered phosphorus was exceeded between 6 and 15 times in The Gulch, Little Valley Wash, Trachyte Creek, and Wahweap Creek and between 1 and 3 times in Coyote Gulch, Harris Wash, Croton Canyon, Last Chance Creek, Tibbet Canyon, and Wesses Canyon.

During the recent period of record for the three rivers, filtered trace elements with five or more exceedances include aluminum in the Paria River (Utah section), barium in the Escalante and Paria Rivers, beryllium in the Paria River (Arizona section), iron in the Paria River (Utah section), and manganese in the Paria River (Utah section). Historical and recent data for filtered selenium in the Paria River indicate elevated concentrations. During the recent period of record, one to eight filtered trace-element concentrations exceeded their standard in analyses of samples collected from 12 of the 14 evaluated tributaries.

Natural geologic processes and multiple anthropogenic factors may contribute to elevated concentrations of selected constituents in GLCA waters. Erosion can result in high levels of solids and sediment that can lead to elevated turbidity, which can in turn result in increased water temperatures, increased concentrations of phosphorus and selected trace 
Table 22. Pesticide compounds with values above censoring levels from samples collected in 1985, 1986, and 2002 in the Escalante and Paria Rivers, Glen Canyon National Recreation Area, Arizona and Utah.

$[\mu \mathrm{g} / \mathrm{L}$, micrograms per liter; --, no data]

\begin{tabular}{lcc}
\hline \multicolumn{1}{c}{$\begin{array}{c}\text { Detected pesticide compound (common name) } \\
\text { (unfiltered recoverable unless otherwise indicated) }\end{array}$} & \multicolumn{2}{c}{ Range of detections, $\boldsymbol{\mu g} / \mathbf{L}$} \\
\cline { 2 - 3 } Escalante & \multicolumn{1}{c}{$\begin{array}{c}\text { Paria } \\
\text { River }\end{array}$} \\
\hline 2,4-dichlorophenoxyacetic acid (2,4-D) & 1 & 1 \\
alpha-Endosulfan & .014 & .014 \\
Aldrin & .004 & .004 \\
Chlordane, technical & .014 & .014 \\
N,N-diethyl-M-toluamide (DEET), filtered, recoverable & 2.9 & -- \\
Diazinon & .6 & .6 \\
Dieldrin & .002 & .002 \\
Endrin & .006 & .006 \\
Heptachlor epoxide & -- & .083 \\
Heptachlor & .003 & .003 \\
o,p'-DDD (DDT metabolite) & .011 & .011 \\
o,p'-DDE (DDT metabolite) & $.004-.01$ & $.004-.015$ \\
o,p'-DDT (DDT metabolite) & .012 & .012 \\
Silvex & .1 & .1 \\
Toxaphene & .24 & .24 \\
\hline
\end{tabular}

elements, and reduced DO concentrations. Routine monitoring would provide a more complete documentation of the natural background levels of these various water-quality measurements and constituents and would aid the park in focusing water-quality management decisions on the most relevant and controllable issues.

\section{Mesa Verde National Park, Colorado}

Mesa Verde National Park (MEVE) is in southwestern Colorado (fig. 17) and was established in 1906 for the preservation of the archeological and other Anasazi cultural resources. The park encompasses much of a prominent mesa (or cuesta) with a steep, highly eroded escarpment at the northern end of the park. Multiple north-south-trending, gently sloping, flat-topped ridges separated by rugged canyons drop from the escarpment to the Mancos River to form numerous ephemeral drainages.

Precipitation in MEVE typically falls as snow in the winter months and as thundershowers in the summer monsoonal period. Climate station 055531 is approximately $7 \mathrm{mi}$ southeast of the park at an elevation of 7,110 ft (fig. 17). Mean annual precipitation is 17.8 inches (1948-2006). August is the wettest month ( 2 inches) and June is the driest (0.6 inch). Average snowfall is 80 inches and the greatest snowfall is typically in January (20 inches). Average monthly temperatures (1948-2006) ranged from $18.5^{\circ} \mathrm{F}$ in January to $86.3^{\circ} \mathrm{F}$ in July, with an average annual temperature of $49.3^{\circ} \mathrm{F}$, and daily extremes ranging from $-20^{\circ} \mathrm{F}$, on January 13,1963 , to $100^{\circ} \mathrm{F}$, on July 13, 1971 (Western Regional Climate Center, 2006).

\section{Geology}

Bedrock in MEVE is composed of Late Cretaceous sandstones and shales. The oldest unit is the Dakota Sandstone, which is porous and permeable, providing potential as a productive formation for oil and gas exploration (Griffitts, 1990; Baars, 2000). The Dakota is overlain by the Mancos Shale, which crops out along the northern and northeastern boundaries of the park. Water derived from the Mancos Shale typically contains naturally elevated concentrations of salts, selenium, and sulfate (Colorado Department of Public Health and Environment, 2002b; Carroll and others, 1998). Next youngest is the Point Lookout Sandstone, which is one of three formations associated with the Mesaverde Group. The Point Lookout Sandstone forms the sandstone caprock in Morefield Canyon (fig. 17; Griffitts, 1990). The Point Lookout Sandstone is an important natural gas reservoir and producer (Carroll and others, 1998). The second member of the Mesaverde Group, the Menefee Formation, is composed 

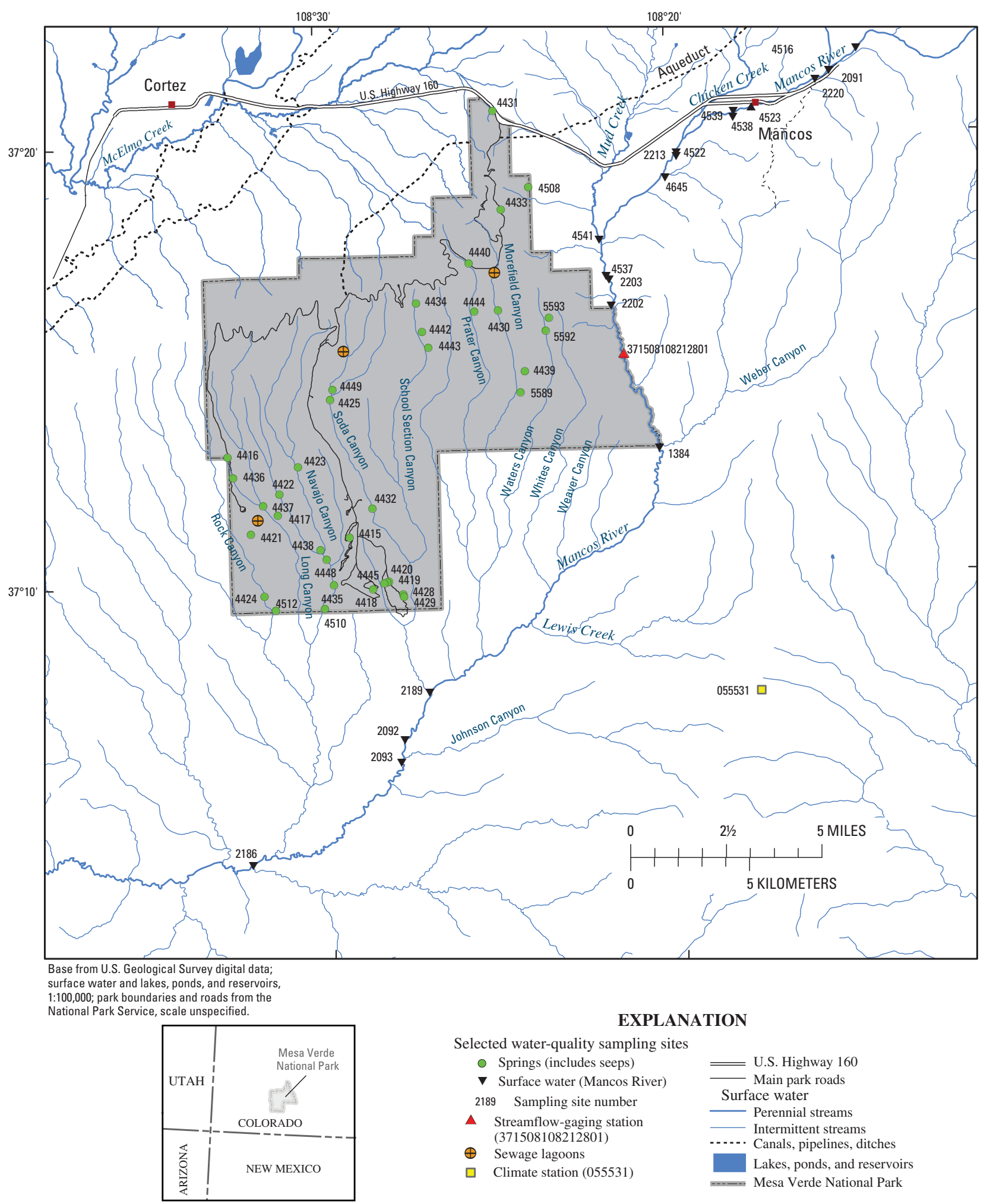

Selected water-quality sampling sites

- Springs (includes seeps)

$\checkmark$ Surface water (Mancos River)

2189 Sampling site number

U.S. Highway 160

- Streamflow-gagingstion

Surface water
Perennial streams

(371508108212801)

$\oplus$ Sewage lagoons

․ Climate station (055531)

- Intermittent streams

-..... Canals, pipelines, ditches

Lakes, ponds, and reservoirs

Location map

Figure 17. Mesa Verde National Park, Colorado, and locations of water-quality sampling sites. 
primarily of easily eroded, gray to brown, carbonaceous shale and sandstone (Baars, 2000). Economically recoverable coal and coal-bed methane resources have been identified in the Menefee Formation (Haines, 2003). The youngest sandstone in the park, the buff-orange Cliff House Formation, caps the mesa in the park (Griffitts, 1990). The Cliff House Sandstone is where the famous Anasazi cliff dwellings are in the park. The porous and permeable sandstones of the Mesaverde Group also are good source rocks for water (Baars, 2000).

\section{Water Resources}

The Mancos River is a perennial stream that originates in the La Plata Mountains north of Mancos, Colorado, and flows for $4.7 \mathrm{mi}$ along the eastern park boundary (fig. 17). A USGS streamflow-gaging station (station 09371000) has been operated on the Mancos River near Towaoc, Colorado, from October 1920 to September 1943 and from February 1951 to 2007. This station is approximately $14 \mathrm{mi}$ downstream from the park. Mean monthly streamflow, for water years 1921 to 2006, was highest in May $\left(171 \mathrm{ft}^{3} / \mathrm{s}\right)$ and lowest in December and January $\left(14 \mathrm{ft}^{3} / \mathrm{s}\right)$. The highest annual mean streamflow was $138 \mathrm{ft}^{3} / \mathrm{s}$ in 1973 and the lowest was $4.28 \mathrm{ft}^{3} / \mathrm{s}$ in 1959 . Average annual runoff, based on 78 years of record, was 1.3 inches in the 526- $\mathrm{mi}^{2}$ drainage basin (U.S. Geological Survey, 2001). Since August 2000, the NPS in cooperation with the USGS has been operating a streamflow-gaging station on the Mancos River in MEVE (station 371508108212801; fig. 17). Typical annual hydrographs for canyons in the Mancos River Basin show flashy responses to summer monsoons and snowmelt-driven peaks in midspring.

The Mancos River supports warm-water aquatic life and primary and secondary-contact recreational use downstream from U.S. Highway 160 along the eastern boundary of the park, to the Colorado-New Mexico border (U.S. Environmental Protection Agency, 2005). The Mancos River in the area of the park supported native fish species (blue head sucker, flannelmouth sucker, speckled dace, and roundtail chub), but these species have disappeared due to drought and associated severe fires in 1996 and 2000 (Thomas and others, 2006).

Water-quality issues for the Mancos River, as identified in the I\&M Phase II Report (Thomas and others, 2006), include nutrient and bacterial contamination from trespass grazing in the Mancos River riparian corridor and from sewage-treatment facilities within and upstream from the park. Insecticide and algicide applications, including aerial mosquito control with Malathion applied directly to lakes and rivers in the area, pesticide applications from surrounding agricultural activities, and herbicide (for example, Tordon) use within the park to control invasive exotic species such as tamarisk and musk thistle, are a water-quality concern. Runoff of silt from neighboring gravel pits, streets, unpaved roads, and construction sites along with runoff from development along the Mancos River corridor upstream from the park is a concern. Metals contamination from mining and ore processing in areas adjacent to and upstream from the park and potential contamination from natural-gas lines crossing the Mancos River upstream from the park are concerns. Fire has been an important factor in and surrounding the park. The most recent fire occurred in 2000, and an accidental drop of fire retardant containing cyanide in the Mancos River resulted in a 7-mi-long fish and invertebrate kill. Sporadic runoff events of water laden with ash and silt have inundated the riverbed within and downstream from the park following the fire (Marilyn Colyer, National Park Service, written commun., February 2005). Drought has been a persistent and intermittently severe environmental condition in this arid region and has, in some years, resulted in sections of the Mancos River entirely drying up. Recent macroinvertebrate sampling in the Mancos River in MEVE shows severely reduced macroinvertebrate and fish populations of limited diversity, but no cause for this condition has been identified (Stephen Monroe, National Park Service, oral commun., October 2006). Additionally, the Mancos River and tributaries, upstream from U.S. Highway 160 and the park, are on the 2004 Colorado 303(d) list of impaired waters for elevated copper concentrations (Colorado Department of Public Health and Environment, 2004).

Numerous springs are found throughout the park, discharging primarily from the exposed sandstone and shale formations of the Mesaverde Group. These springs, although typically very small, compose the critical water resources available to wildlife. Additional water sources in the park include pools, reservoirs, pits, and potholes, many of which are perennial and also serve as important sources of water for wildlife. Water-quality issues for the park's springs, as identified in the I\&M Phase II Report (Thomas and others, 2006) include atmospheric pollutant deposition from coalfired powerplants and oil and gas development in the Four Corners area (Williams and Tonnessen, 2000; Barrows, 2003; San Juan Citizens Alliance, 2002), erosion and water-quality effects from large episodic forest fires (Floyd, Romme, and Hanna, 2000; Floyd and Salamacha, 2001; Gaug, 2001), and discharge from sewage lagoons in Soda, Morefield, and Navajo Canyons.

\section{Available Water-Quality Data}

The data analyzed for MEVE in this report were collected by the USGS, NPS, USFS, CDPHE, and Colorado River Watch. Data are available for 57 sites within the park, including data for 37 springs, 1 stream site, 18 lakes (including reservoirs, ponds, or potholes), 2 diversions or canals, and 3 sewage outfalls. Data for 237 sites were retrieved for the area surrounding the park, including data for 11 springs, 155 stream sites (including sites from the Mancos River, McElmo Creek, and Dolores River), 9 diversions or canals, 46 groundwater sites, 14 lake sites (including reservoirs, ponds, or potholes), and 2 sewage outfalls. The following discussion focuses on selected sites on the Mancos River in the vicinity of the park and selected springs inside the park (fig. 17; table 23). Data from McElmo Creek and the Dolores River 
Table 23. Mancos River and spring sites with water-quality data in, upstream from, and downstream from Mesa Verde National Park, Colorado, 1971 to 2002.

[APW, Ancestral Pueblo; DD, decimal degrees; HS, High School; JHS, Junior High School; no., number; *, sites located within park boundary; site names retained from original source database]

\begin{tabular}{|c|c|c|c|c|c|}
\hline $\begin{array}{l}\text { Site } \\
\text { no. }\end{array}$ & Site name & $\begin{array}{c}\text { Latitude } \\
\text { DD }\end{array}$ & $\begin{array}{c}\text { Longitude } \\
\text { DD }\end{array}$ & $\begin{array}{c}\text { No. of } \\
\text { samples }\end{array}$ & Period of record \\
\hline \multicolumn{6}{|c|}{ Mancos River sites } \\
\hline $1384 *$ & Mancos River above Weber Canyon & 37.2161 & 108.3403 & 1 & 1975 \\
\hline 2091 & Mancos River near Mancos, Co. & 37.3572 & 108.2548 & 3 & $1975-2002$ \\
\hline 2092 & Mancos River near Cortez, Co. & 37.1078 & 108.4640 & 31 & 1976-1979 \\
\hline 2093 & Mancos River below Johnson Canyon near Cortez, Co. & 37.0992 & 108.4662 & 44 & 1979-1982 \\
\hline 2202 & Mancos River above Canyon & 37.2703 & 108.3609 & 1 & 1975 \\
\hline 2203 & Mancos River 1.2 Miles below Mud Creek & 37.2800 & 108.3619 & 4 & 1994 \\
\hline 2213 & Mancos River at H Road, below Chicken Creek & 37.3272 & 108.3289 & 5 & 1975-1994 \\
\hline 2220 & Mancos River below East and West Forks & 37.3536 & 108.2611 & 16 & 1978-1994 \\
\hline 4516 & Mancos River at Mancos & 37.3667 & 108.2667 & 122 & 1971-2001 \\
\hline 4522 & Mancos HS Greer Br Mancos HS & 37.3270 & 108.3290 & 92 & 1994-1998 \\
\hline 4539 & Mancos River below Mancos Sewer Outlet & 37.3445 & 108.3014 & 1 & 1995 \\
\hline 4541 & Mancos River below Confluence with Mud Creek & 37.2950 & 108.3658 & 1 & 1995 \\
\hline 4645 & Mancos River downstream of Mancos & 37.3185 & 108.3336 & 1 & 1989 \\
\hline \multicolumn{6}{|c|}{ Spring sites } \\
\hline $4415 *$ & Spruce Tree House Spring (Cliff Canyon) & 37.1844 & 108.4874 & 15 & $1983-1998$ \\
\hline $4416^{*}$ & Rock Spring & 37.2159 & 108.5452 & 1 & 1984 \\
\hline $4417 *$ & Spring House Spring (Long Canyon) & 37.1934 & 108.5221 & 2 & 1988 \\
\hline $4418 *$ & Fewkes Canyon Spring (Cliff Canyon) & 37.1646 & 108.4779 & 2 & $1983-1984$ \\
\hline $4419 *$ & Spring 155 Yards North of Sunset House (Cliff Canyon) & 37.1674 & 108.4703 & 1 & 1994 \\
\hline $4420 *$ & 150 Yards North of Sunset House (Cliff Canyon) & 37.1672 & 108.4703 & 1 & 1994 \\
\hline $4421 *$ & Long House Spring & 37.1865 & 108.5352 & 12 & $1983-1998$ \\
\hline $4422 *$ & Wickiup Canyon Spring & 37.2014 & 108.5211 & 1 & 1984 \\
\hline $4432 *$ & Soda Canyon Spring at APW Trail & 37.1952 & 108.4772 & 2 & $1987-1992$ \\
\hline $4433 *$ & Big Hill Pipes & 37.3071 & 108.4127 & 3 & 1984-1995 \\
\hline $4434 *$ & School Section Canyon Springs & 37.2725 & 108.4541 & 3 & 1987-1994 \\
\hline $4435^{*}$ & Echo Cliffs Drainage Spring & 37.1664 & 108.4965 & 2 & 1991 \\
\hline $4436 *$ & Rock Springs near Roadcut & 37.2079 & 108.5429 & 2 & 1986-1987 \\
\hline $4437 *$ & Long Canyon Drainage & 37.1972 & 108.5289 & 1 & 1990 \\
\hline $4438 *$ & Wickiup Slump Pothole & 37.1800 & 108.5023 & 1 & 1987 \\
\hline $4439 *$ & Morefield Ridge Road Spring & 37.2458 & 108.4032 & 1 & 1987 \\
\hline $4440 *$ & Prater Canyon Drainage Spring & 37.2871 & 108.4286 & 1 & 1987 \\
\hline $4442 *$ & School Section Canyon Springs & 37.2616 & 108.4517 & 1 & 1993 \\
\hline $4444 *$ & Turkey Spring & 37.2688 & 108.4265 & 1 & 1994 \\
\hline $4445^{*}$ & Cliff Palace Spring (Cliff Canyon) & 37.1668 & 108.4726 & 1 & 1994 \\
\hline $5589 *$ & Morefield Spring & 37.2378 & 108.4056 & 12 & 1977-1998 \\
\hline $5593 *$ & Waters Spring & 37.2656 & 108.3912 & 1 & 1993 \\
\hline
\end{tabular}


(approximately 9 miles north of MEVE) were not included because these streams are outside the park boundary.

The frequency of water-quality sample collection along the Mancos River has varied with few sites offering more than a historical snapshot of water-quality conditions. The relative temporal distribution of water samples from Mancos River sites with available data is illustrated in table 24. Only three sites $(4516,4522$, and 4537$)$ have 5 or more years of record since 1971. From 1971 to 1988, 190 water samples were collected from 10 sites on the Mancos River; most of the samples (31, 44, 12, and 95 samples) were collected from 4 sites (sites 2092, 2093, 2220, and 4516, respectively); all other sites had only one or two samples (fig. 17; tables 23 and 24). From 1988 to 2002, 205 samples were collected from 11 sites on the Mancos River; most of these samples $(92,63,27$, and 13 samples) were collected from four sites (sites 4522, 4523, 4516 , and 4537, respectively), and all other sites had only one or two samples collected during this time. Site 1384 is within the park at the downstream park boundary; however, it was only sampled once in October 1975. Sites 2091 and 4516 are the only two sites sampled since 2000.

The relative temporal distribution of water samples from springs with available data is illustrated in table 25. Waterquality data for springs were collected by the NPS at 36 sites in MEVE. Between 1977 and 1988, 26 samples were collected from 18 sites, and from 1988 to 1998, a total of 76 samples were collected from 27 sites. One-half of the samples were collected from four springs, which included sites 4415, 4421, 4431, and 5589 (fig. 17; tables 23 and 25) with 15, 12, 13, and 12 samples collected, respectively, over the complete period of record.

The SCPN water-quality database contains approximately 390 field properties or constituents for MEVE. A subset of these characteristics were analyzed and presented in this report for selected Mancos River sites and springs, including field properties ( $\mathrm{pH}$ and $\mathrm{SC}$ ), major ions, nutrients, trace elements (aluminum, arsenic, barium, cadmium, chromium, copper, iron, lead, manganese, molybdenum, nickel, selenium, silver, zinc), and fecal and total coliform bacteria. Measurements were made at several stream sites on the Mancos River for instantaneous streamflow, daily discharge, and (or) stream stage. No discharge data were available from the springs inside the park.

\section{Characterization of Water Quality}

\section{Surface-Water Quality}

Surface-water-quality data were collected by the NPS, USGS, USFS, CDPHE, and Colorado River Watch at 18 sites on the Mancos River in the area upstream from, in, and downstream from the park (fig. 17; table 23). The sampling sites in and upstream from the park are primarily within outcrop areas of the Mancos Shale with a few sites in the gravels and alluvium overlying the Mancos Shale (Utah State University, 2004). Upstream from the sampling sites, the headwaters of the Mancos River flow through predominantly siltstone, mudstone, sandstone, and shale (some of which is the Mancos Shale). The sites downstream from MEVE are primarily in the Menefee Formation with a few sites in intrusive rocks of middle Tertiary age.

In order to describe what is known regarding waterquality conditions as the Mancos River enters the park, waterquality data for three Mancos River sampling sites directly upstream from the park and downstream from the Mud Creek tributary (sites 2202, 2203, and 4537) are summarized in table 26 (fig. 17). Two of these sites (2203 and 4537) had samples collected since 1988; however, site 2203 was sampled only twice in March and July 1994. Site 2202 was sampled only once in October 1975. Data from site 1384, the only site sampled within the park, also is summarized in table 26. Data for the remaining Mancos River sites were not included in the summary or this analysis due to the sites' distance from the park; however, when meaningful, references to Mancos River data from sites farther upstream or downstream from the park are made.

Field properties, selected major ions, and one or more trace-element and nutrient constituents were measured or analyzed in samples from each of the four sites (sites 1384, 2202,2203 , and 4537), though the same field properties and constituents were not always measured or analyzed in samples from all sites. Streamflow was measured at three of the sites, but these were each measured only one or two times. Streamflow was not measured at site 4537, which has the longest water-quality sample record (from 1986 to 1998). Total or fecal coliform was measured in samples collected seven times between 1991 and 1998 from site 4537 and once in July 1995 from site 4541 (upstream from site 2203, fig. 17). No other water-quality constituents were measured in samples from site 4541.

\section{Field Properties}

At the four sites on the Mancos River within or directly upstream from the park with data, $14 \mathrm{pH}$ measurements were made between 1975 and 1998; 10 were made during the recent period of record. Of these recent measurements, one $\mathrm{pH}$ value of 6.1 SU (table 26) was measured at site 4537 in September 1991 and was outside the 6.5-9.0 SU range defined by CDPHE for cold- and warm-water aquatic life. All other values ranged between 7.3 to $8.4 \mathrm{SU}$ for these sites.

Specific conductance was measured 14 times at the four sites on the Mancos River within or directly upstream from the park and ranged from 947 to $2,253 \mu \mathrm{S} / \mathrm{cm}$ for the four sites sampled between 1975 and 1998. Corresponding historical streamflow data are insufficient to determine how flow is related to conductivity in this section of the Mancos River. Stream SC measurements did not correlate with spring $\mathrm{SC}$ measurements made on the same date. Generally, lower conductivity values are associated with higher flow conditions 
Table 24. Period of record and sample counts for sites with water-quality data on the Mancos River in and near Mesa Verde National Park, Colorado, 1971 to 2002.

[no., number; --, no samples; numbers in boxes indicate number of water-quality samples collected during the specified year]

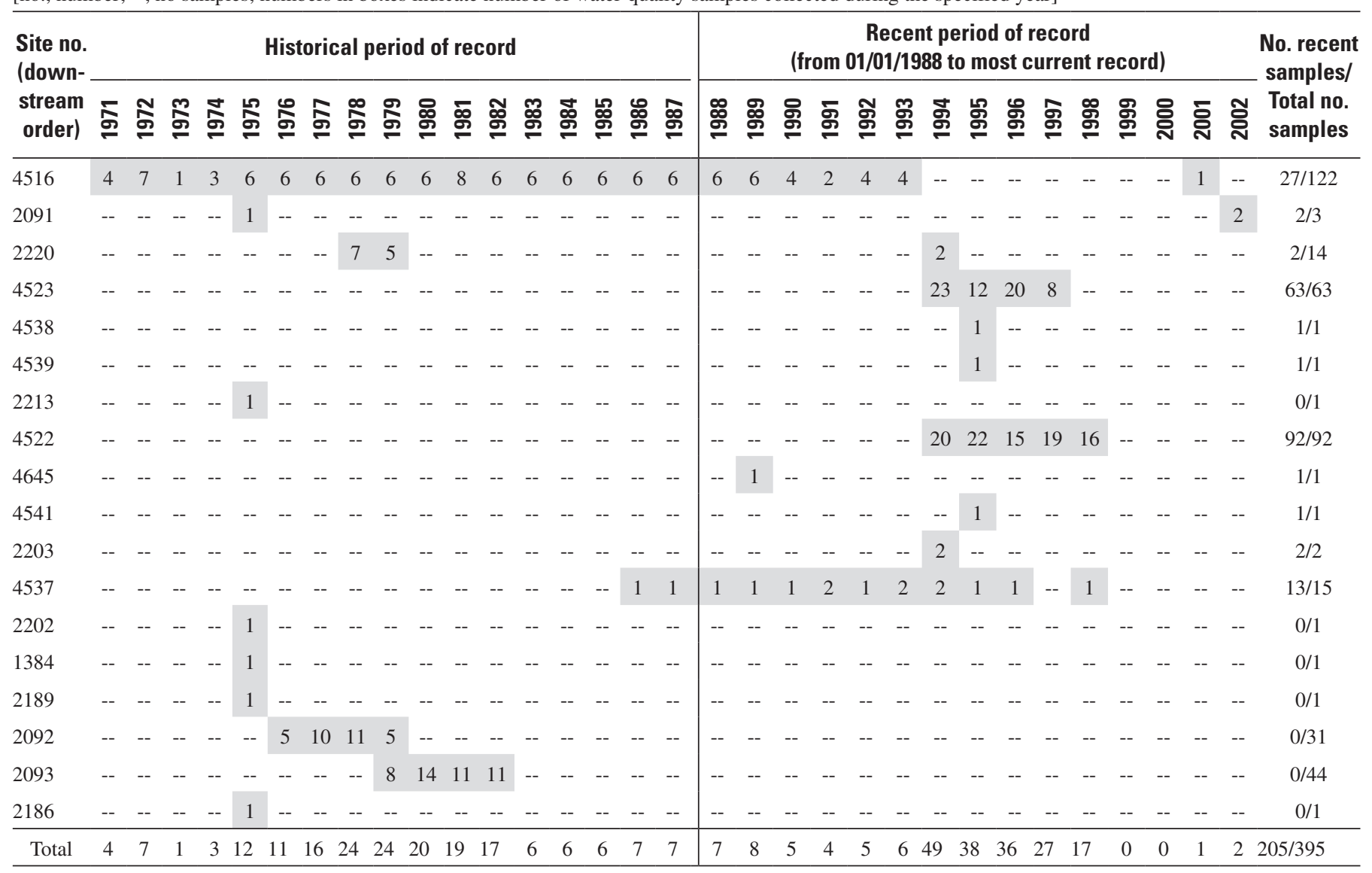


Table 25. Period of record and sample counts for springs in Mesa Verde National Park, Colorado, with water-quality data, 1977 to 1998 .

[no., number; --, no samples; numbers in boxes indicate number of water-quality samples collected during the specified year; sites in bold were sampled 12 or more times]

\begin{tabular}{|c|c|c|c|c|c|c|c|c|c|c|c|c|c|c|c|c|c|c|c|c|c|c|c|}
\hline \multirow{2}{*}{$\begin{array}{l}\text { Site } \\
\text { no. }\end{array}$} & \multicolumn{11}{|c|}{ Historical period of record } & \multicolumn{11}{|c|}{$\begin{array}{l}\text { Recent period of record } \\
\text { (from 01/01/1988 to most current record) }\end{array}$} & \multirow{2}{*}{$\begin{array}{c}\text { No. recen } \\
\text { samples } \\
\text { Total no. } \\
\text { samples }\end{array}$} \\
\hline & 音 & $\stackrel{\infty}{\stackrel{\infty}{\sigma}}$ & $\underset{\sigma}{\stackrel{\sigma}{\sigma}}$ & 品 & চ্口 & ঞ্চ & ஜ্口 & 足 & $\begin{array}{l}\text { 노 } \\
\stackrel{\circ}{\sigma}\end{array}$ & $\begin{array}{l}\mathscr{2} \\
\stackrel{\circ}{\sigma}\end{array}$ & ஜ্ळ & $\stackrel{\text { ஜ̊ }}{\stackrel{\sigma}{\sigma}}$ & $\begin{array}{l}\text { : } \\
\stackrel{\circ}{\sigma}\end{array}$ & 욤 & g. & ฆั & ஜூ & 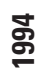 & ㄴㅇㅇ & ஜூ & 욤 & 号 & \\
\hline 4415 & -- & -- & -- & -- & -- & -- & 1 & 1 & -- & -- & 1 & 1 & 1 & 1 & 1 & -- & 1 & 1 & 3 & 1 & 1 & 1 & $12 / 15$ \\
\hline 4416 & -- & -- & -- & -- & -- & -- & -- & 1 & -- & -- & -- & -- & -- & -- & -- & -- & -- & -- & -- & -- & -- & -- & $0 / 1$ \\
\hline 4417 & -- & -- & -- & -- & -- & -- & -- & -- & -- & -- & -- & 1 & -- & -- & -- & -- & -- & -- & -- & -- & -- & 1 & $2 / 2$ \\
\hline 4418 & -- & -- & -- & -- & -- & -- & 1 & 1 & -- & -- & -- & -- & -- & -- & -- & -- & -- & -- & -- & -- & -- & -- & $0 / 2$ \\
\hline 4419 & -- & -- & -- & -- & -- & -- & -- & -- & -- & -- & -- & -- & -- & -- & -- & -- & -- & 1 & -- & -- & -- & -- & $1 / 1$ \\
\hline 4420 & -- & -- & -- & -- & -- & -- & -- & -- & -- & -- & -- & -- & -- & -- & -- & -- & -- & 1 & -- & -- & -- & -- & $1 / 1$ \\
\hline 4421 & -- & -- & -- & -- & -- & -- & 1 & 1 & -- & -- & -- & 1 & 1 & -- & 1 & -- & 1 & 2 & 2 & 1 & -- & 1 & $10 / 12$ \\
\hline 4422 & -- & -- & -- & -- & -- & -- & -- & 1 & -- & -- & -- & -- & -- & -- & -- & -- & -- & -- & -- & -- & -- & -- & $0 / 1$ \\
\hline 4423 & -- & -- & -- & -- & -- & -- & -- & -- & -- & -- & -- & 1 & -- & -- & -- & -- & -- & -- & -- & -- & -- & -- & $1 / 1$ \\
\hline 4424 & -- & -- & -- & -- & -- & -- & -- & -- & -- & -- & -- & -- & 1 & -- & -- & -- & -- & -- & -- & -- & -- & -- & $1 / 1$ \\
\hline 4425 & -- & -- & -- & -- & -- & -- & -- & -- & -- & -- & -- & -- & 1 & -- & -- & 1 & -- & -- & -- & -- & -- & -- & $2 / 2$ \\
\hline 4428 & -- & -- & -- & -- & -- & -- & -- & -- & -- & -- & -- & -- & -- & -- & -- & 1 & -- & -- & 2 & -- & -- & -- & $3 / 3$ \\
\hline 4429 & -- & -- & -- & -- & -- & -- & -- & -- & -- & -- & -- & -- & -- & -- & -- & -- & -- & -- & -- & -- & -- & 1 & $1 / 1$ \\
\hline 4430 & -- & -- & -- & -- & -- & -- & -- & -- & -- & -- & -- & -- & -- & -- & 1 & -- & -- & -- & -- & -- & -- & 1 & $2 / 2$ \\
\hline 4431 & -- & -- & -- & -- & -- & -- & -- & -- & -- & -- & 1 & -- & 1 & 1 & 2 & -- & 2 & 2 & 2 & 1 & -- & 1 & $12 / 13$ \\
\hline 4432 & -- & -- & -- & -- & -- & -- & -- & -- & -- & -- & 1 & -- & -- & -- & -- & 1 & -- & -- & -- & -- & -- & -- & $1 / 2$ \\
\hline 4433 & -- & -- & -- & -- & -- & -- & -- & 1 & -- & -- & 1 & -- & -- & -- & -- & -- & -- & -- & 1 & -- & -- & -- & $1 / 3$ \\
\hline 4434 & -- & -- & -- & -- & -- & -- & -- & -- & -- & -- & 1 & 1 & -- & -- & -- & -- & -- & 1 & -- & -- & -- & -- & $2 / 3$ \\
\hline 4435 & -- & -- & -- & -- & -- & -- & -- & -- & -- & -- & -- & -- & -- & -- & 2 & -- & -- & -- & -- & -- & -- & -- & $2 / 2$ \\
\hline 4436 & -- & -- & -- & -- & -- & -- & -- & -- & -- & 1 & 1 & -- & -- & -- & -- & -- & -- & -- & -- & -- & -- & -- & $0 / 2$ \\
\hline 4437 & -- & -- & -- & -- & -- & -- & -- & -- & -- & -- & -- & -- & -- & 1 & -- & -- & -- & -- & -- & -- & -- & -- & $1 / 1$ \\
\hline 4438 & -- & -- & -- & -- & -- & -- & -- & -- & -- & -- & 1 & -- & -- & -- & -- & -- & -- & -- & -- & -- & -- & -- & $0 / 1$ \\
\hline 4439 & -- & -- & -- & -- & -- & -- & -- & -- & -- & -- & 1 & -- & -- & -- & -- & -- & -- & -- & -- & -- & -- & -- & $0 / 1$ \\
\hline 4440 & -- & -- & -- & -- & -- & -- & -- & -- & -- & -- & 1 & -- & -- & -- & -- & -- & -- & -- & -- & -- & -- & -- & $0 / 1$ \\
\hline 4442 & -- & -- & -- & -- & -- & -- & -- & -- & -- & -- & -- & -- & -- & -- & -- & -- & 1 & -- & -- & -- & -- & -- & $1 / 1$ \\
\hline 4443 & -- & -- & -- & -- & -- & -- & -- & -- & -- & -- & -- & -- & -- & -- & -- & -- & 1 & 1 & -- & -- & -- & -- & $2 / 2$ \\
\hline 4444 & -- & -- & -- & -- & -- & -- & -- & -- & -- & -- & -- & -- & -- & -- & -- & -- & -- & 1 & -- & -- & -- & -- & $1 / 1$ \\
\hline 4445 & -- & -- & -- & -- & -- & -- & -- & -- & -- & -- & -- & -- & -- & -- & -- & -- & -- & 1 & -- & -- & -- & -- & $1 / 1$ \\
\hline 4446 & -- & -- & -- & -- & -- & -- & -- & -- & -- & -- & -- & -- & -- & -- & -- & -- & -- & -- & 1 & -- & -- & -- & $1 / 1$ \\
\hline 4448 & 1 & -- & -- & -- & -- & -- & -- & -- & -- & -- & -- & -- & -- & -- & -- & -- & -- & -- & -- & -- & -- & -- & $0 / 1$ \\
\hline 4449 & 1 & -- & -- & -- & -- & -- & -- & -- & -- & -- & -- & -- & -- & -- & -- & -- & -- & -- & -- & -- & -- & -- & $0 / 1$ \\
\hline 4508 & -- & -- & -- & -- & -- & -- & -- & 1 & -- & -- & -- & 1 & -- & -- & -- & -- & -- & -- & 1 & -- & -- & 1 & $3 / 4$ \\
\hline 4510 & -- & -- & -- & -- & -- & -- & -- & 1 & -- & -- & -- & -- & -- & -- & 1 & -- & -- & -- & -- & -- & -- & -- & $1 / 2$ \\
\hline 5589 & 1 & -- & -- & -- & -- & -- & 1 & 1 & -- & -- & -- & -- & -- & 1 & 1 & -- & 2 & 2 & 1 & 1 & -- & 1 & $9 / 12$ \\
\hline 5592 & -- & -- & -- & -- & -- & -- & -- & -- & -- & -- & -- & -- & -- & 1 & -- & -- & -- & -- & -- & -- & -- & -- & $1 / 1$ \\
\hline 5593 & -- & -- & -- & -- & -- & -- & -- & -- & -- & -- & -- & -- & -- & -- & -- & -- & 1 & -- & -- & -- & -- & -- & $1 / 1$ \\
\hline Total & 3 & 0 & 0 & 0 & 0 & 0 & 4 & 9 & 0 & 1 & 9 & 6 & 5 & 5 & 9 & 3 & 9 & 13 & 13 & 4 & 1 & 8 & $76 / 102$ \\
\hline
\end{tabular}


Table 26. Statistical summary of water-quality data and exceedances of water-quality standards in selected Mancos River sites located directly upstream from or within Mesa Verde National Park, Colorado, 1975 to 1998.

[AL, aquatic life; ALW2, aquatic-life warm-water class 2; CDPHE, Colorado Department of Public Health and Environment; EPA RC III, U.S. Environmental Protection Agency National Recommended Nutrient Criteria for Ecoregion III; fil, filtered; GM, geometric mean; L, low (minimum) standard; mg/L, milligrams per liter; MPN, most probable number; N, nitrogen; NAWQ, National Ambient Water Quality; No., number; P, phosphorus; PCR, primary contact recreation; POR, period of record; TVS, table value standard; unfil, unfiltered; $\mu \mathrm{S} / \mathrm{cm}$, microsiemens per centimeter; <, less than; --, not available; bold type indicates exceedance during recent POR]

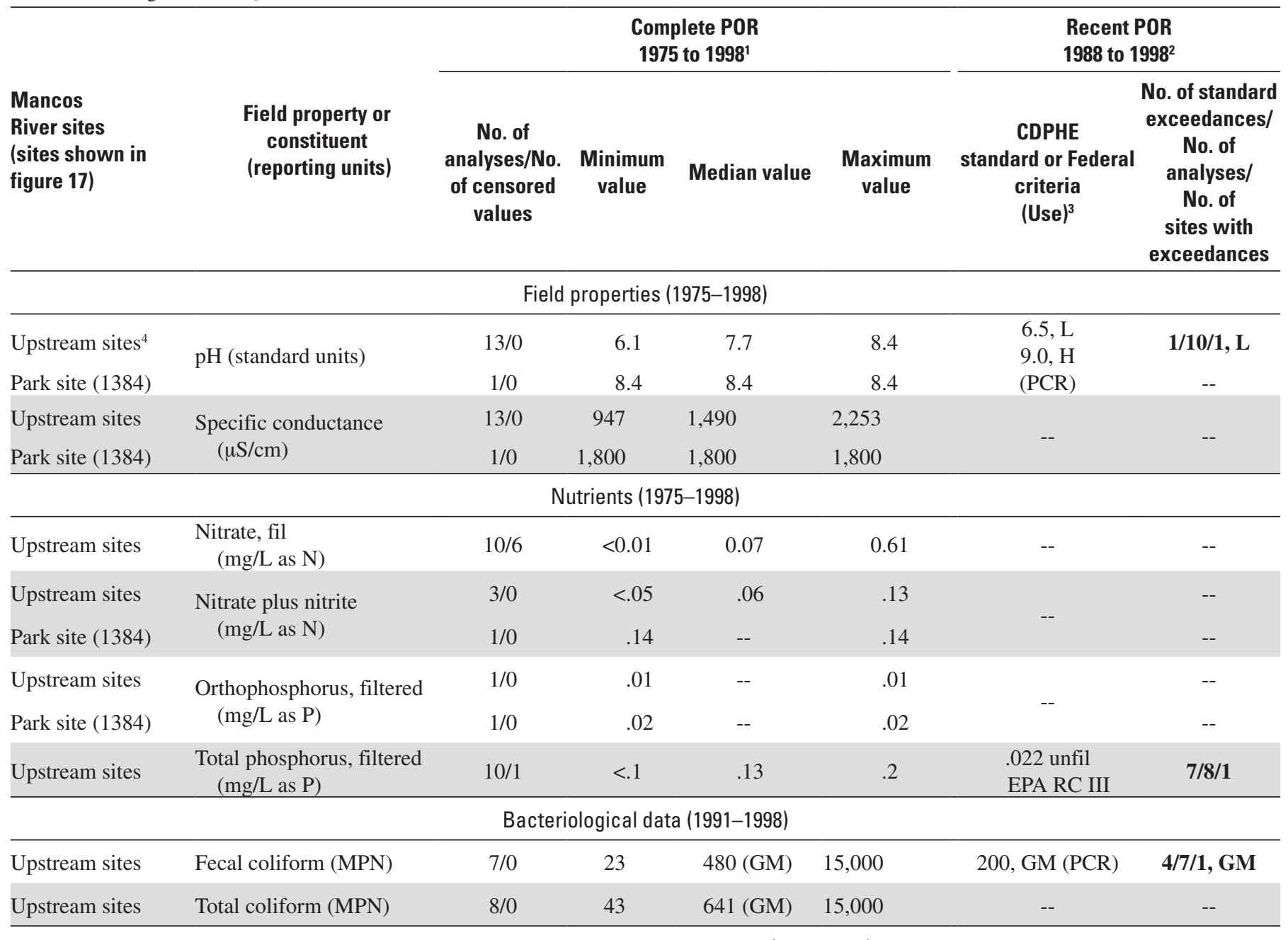

Trace elements, in micrograms per liter (1975-1998)

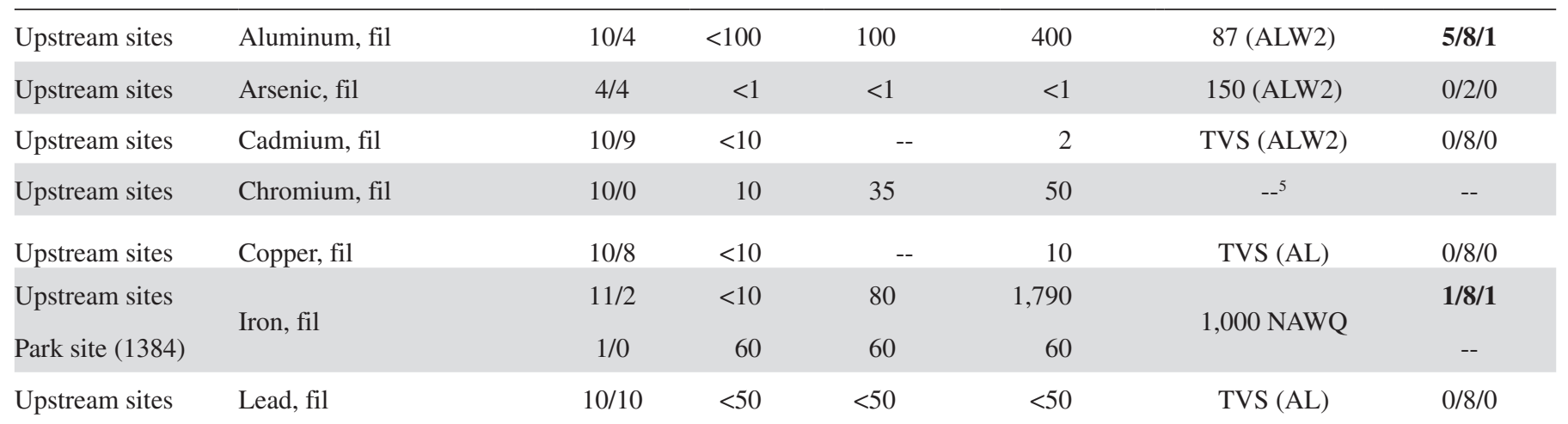


Table 26. Statistical summary of water-quality data and exceedances of water-quality standards in selected Mancos River sites located directly upstream from or within Mesa Verde National Park, Colorado, 1975 to 1998. - Continued

[AL, aquatic life; ALW2, aquatic-life warm-water class 2; CDPHE, Colorado Department of Public Health and Environment; EPA RC III, U.S. Environmental Protection Agency National Recommended Nutrient Criteria for Ecoregion III; fil, filtered; GM, geometric mean; L, low (minimum) standard; mg/L, milligrams per liter; MPN, most probable number; N, nitrogen; NAWQ, National Ambient Water Quality; No., number; P, phosphorus; PCR, primary contact recreation; POR, period of record; TVS, table value standard; unfil, unfiltered; $\mu \mathrm{S} / \mathrm{cm}$, microsiemens per centimeter; <, less than; --, not available; bold type indicates exceedance during recent POR]

\begin{tabular}{|c|c|c|c|c|c|c|c|}
\hline \multirow[b]{2}{*}{$\begin{array}{l}\text { Mancos } \\
\text { River sites } \\
\text { (sites shown in } \\
\text { figure 17) }\end{array}$} & \multirow[b]{2}{*}{$\begin{array}{l}\text { Field property or } \\
\text { constituent } \\
\text { (reporting units) }\end{array}$} & \multicolumn{4}{|c|}{$\begin{array}{c}\text { Complete POR } \\
1975 \text { to } 1998^{1}\end{array}$} & \multicolumn{2}{|c|}{$\begin{array}{l}\text { Recent POR } \\
1988 \text { to } 1998^{2} \\
\end{array}$} \\
\hline & & $\begin{array}{c}\text { No. of } \\
\text { analyses/No. } \\
\text { of censored } \\
\text { values }\end{array}$ & $\begin{array}{l}\text { Minimum } \\
\text { value }\end{array}$ & Median value & $\begin{array}{l}\text { Maximum } \\
\text { value }\end{array}$ & $\begin{array}{l}\text { CDPHE } \\
\text { standard or Federal } \\
\text { criteria } \\
(\text { Use })^{3}\end{array}$ & $\begin{array}{c}\text { No. of standard } \\
\text { exceedances/ } \\
\text { No. of } \\
\text { analyses/ } \\
\text { No. of } \\
\text { sites with } \\
\text { exceedances }\end{array}$ \\
\hline \multicolumn{8}{|c|}{ Trace elements, in micrograms per liter (1975-1998)—Continued } \\
\hline Upstream sites & \multirow{2}{*}{ Manganese, fil } & $11 / 2$ & $<10$ & 20 & 70 & TVS (AL) & $0 / 8 / 0$ \\
\hline Park site (1384) & & $1 / 0$ & 30 & 30 & 30 & -- & -- \\
\hline Upstream sites & Zinc, fil & $10 / 4$ & $<10$ & 10 & 3,100 & TVS (AL) & $1 / 8 / 1$ \\
\hline
\end{tabular}

${ }^{1}$ All available data considered from 1975 to 1998 ; POR reflects range for individual sites within this time period.

${ }^{2}$ Last 15 years of available data considered for standards exceedance analysis (that is, all samples collected on or after January 1, 1988 through December 31 , 2003). At the time of data compilation no data were available from the source databases collected at these selected sites after 1998.

${ }^{3}$ State standards and designated beneficial uses from the Colorado Department of Public Health and Environment (2002a). Selected Federal criteria are used when State standards are not established, including the USEPA National Recommended Nutrient Criteria for Ecoregions II and III (U.S. Environmental Protection Agency, 2002) or the secondary chronic Tier II values (Suter and Tsao, 1996).

${ }^{4}$ Upstream sites include those sites located downstream from Mud Creek, and upstream from Mesa Verde National Park (Sites 2202, 2203, 4537, and 4541 [bacteriological data only]). Sites with data for specified constituents are indicated; not all constituents were sampled at all sites.

${ }^{5}$ Filtered unspeciated chromium is not regulated in Colorado. Chromium III and VI are regulated for aquatic-life toxicity as is total chromium $(50 \mu \mathrm{g} / \mathrm{L}$ for drinking water); however, no speciated chromium data were available for these sites. 
when more dilute snowmelt or rainwater account for most of the streamflow; higher conductivity values are typically associated with lower flow conditions.

\section{Major lons}

Sulfate was the dominant anion in analyses of water samples collected from the Mancos River, and concentrations ranged from 365 to $1,018 \mathrm{mg} / \mathrm{L}$ at the sites within and directly upstream from the park. Concentrations of sulfate and bicarbonate tended to increase with distance downstream, which is likely the result of influence of the Mancos Shale. No aquaticlife or recreational water-quality standards are associated with sulfate; however, the secondary drinking-water standard of $250 \mathrm{mg} / \mathrm{L}$ was exceeded in 69 of 194 analyses (36 percent) in samples collected between 1975 and 1994 from all sites (from the upstream site 4516 to the downstream site 2186).

Few sites had adequate major ion data to characterize water type for the Mancos River; even with few data, however, some patterns were evident between upstream and downstream sites. The water type is a calcium-magnesium sulfate water (fig. 18) in the area within and directly upstream from the park. Farther upstream, Site 2091, near the upstream outcrop extent of the Mancos Shale, is higher in calcium and bicarbonate, while farther downstream, below the East and West Forks of the Mancos River, site 2213 is higher in sulfate. As the Mancos River flows along the park boundary and farther downstream (sites 2202, 1384, 2092, and 2093), sulfate becomes more prevalent, indicating an increasing effect of drainage from Mancos Shale and Menefee Formation terrains.

\section{Nutrients}

Samples were collected for analysis of nitrate (filtered), nitrate plus nitrite (unfiltered and filtered), orthophosphorus (filtered), and total phosphorus (filtered) between 1 and 10 times at the sites on the Mancos River in and directly upstream from the park between 1975 and 1998 (table 26).

Nitrate was analyzed in samples 10 times at one site (4537), just upstream from the park, from 1986 to 1998; concentrations ranged from less than 0.01 to $0.61 \mathrm{mg} / \mathrm{L}$ with a median value of $0.07 \mathrm{mg} / \mathrm{L}$. Nitrate plus nitrite was analyzed in samples four times from three sites (sites 1384, 2202, and 2203), and concentrations ranged from less than 0.05 to $0.14 \mathrm{mg} / \mathrm{L}$.

Orthophosphorus was analyzed once each in samples from two sites (sites 1384 and 2202) with concentrations of 0.02 and $0.01 \mathrm{mg} / \mathrm{L}$, respectively. Total phosphorus was analyzed in 10 samples collected from 1986 to 1998 from site 4537; concentrations ranged from less than 0.1 to $0.2 \mathrm{mg} / \mathrm{L}$ with a median concentration of $0.13 \mathrm{mg} / \mathrm{L}$. Analyses of seven of the eight recent (since 1988) samples collected from this site exceeded the USEPA-recommended criterion of $0.022 \mathrm{mg} / \mathrm{L}$ for total phosphorus. Nutrient data were generally sparse and not consistently sampled between upstream and downstream sites; therefore, potential nutrient effects from the park's sewage lagoons, surrounding agricultural land, or upstream development could not be evaluated from this small historical dataset.

\section{Bacteriological Data}

Mancos River site 4537 was sampled seven times for analyses of fecal coliform, and sites 4537 and 4541 were sampled a total of eight times for analyses of total coliforms (table 26). Analyses of samples from site 4537 exceeded the primary-contact recreation standard for fecal coliform of $200 \mathrm{col} / 100 \mathrm{~mL}$ four times. Site 4541 was sampled only once and the total coliform measurement did not exceed this standard. No surface-water standard exists in Colorado for total coliforms.

\section{Trace Elements}

For the four Mancos River sites within or directly upstream from the park (fig. 17, sites 1384, 2202, 2203, and 4537), one or more filtered trace elements were analyzed from samples, including aluminum, arsenic, cadmium, chromium, copper, iron, lead, manganese, molybdenum, nickel, selenium, and zinc. These four sites were periodically sampled 1 to 13 times between 1975 and 1998 (table 26). Of these four sites, only site 4537 had multiple samples collected and analyzed for trace elements; all of these samples were collected between 1986 and 1998. Samples from site 2203 were analyzed twice for selenium in March and July 1994. Samples from sites 1384 and 2202 collected only once in October 1975 were each analyzed for a few trace elements (iron and manganese for site 1384; and arsenic, iron, manganese, mercury, and selenium for site 2202).

Ten samples from site 4537 were analyzed for various trace elements, including aluminum, cadmium, chromium, copper, iron, lead, manganese, molybdenum, nickel, selenium, and zinc. Of these, values of aluminum, iron and zinc exceeded their State standard or Federal criteria. Aluminum concentrations ranged from less than 100 to $400 \mu \mathrm{g} / \mathrm{L}$ from site 4537; five concentrations, in analyses of samples from 1988 to 1995 , exceeded the chronic aluminum aquatic-life standard of $87 \mu \mathrm{g} / \mathrm{L}$. Iron concentrations ranged from less than 10 to $1,790 \mu \mathrm{g} / \mathrm{L}$ and a median value of $80 \mu \mathrm{g} / \mathrm{L}$. No aquaticlife standard for filtered iron exists for Colorado waters; however, the NAWQ criterion for filtered iron is $1,000 \mu \mathrm{g} / \mathrm{L}$, and one result from a filtered sample collected in September 1994 exceeded this standard. Lead concentrations were all measured as nondetect (less than $50 \mu \mathrm{g} / \mathrm{L}$ ), which was higher than the computed TVS. Analyses of samples collected from site 4537 exceeded the TVS for zinc (computed as $382.4 \mu \mathrm{g} / \mathrm{L}$ ) once in July 1998 with a value of 3,100 $\mu \mathrm{g} / \mathrm{L}$.

The Mancos River and tributaries, upstream from U.S. Highway 160, are listed as impaired due to copper contamination in the 2004 303(d) list (Colorado Department of Public Health and Environment, 2004); however, none of the data for site 4537 exceeded the computed TVS for copper (computed as $29.3 \mu \mathrm{g} / \mathrm{L}$ ). Copper data were not available for the other sites directly upstream from or within the boundaries 


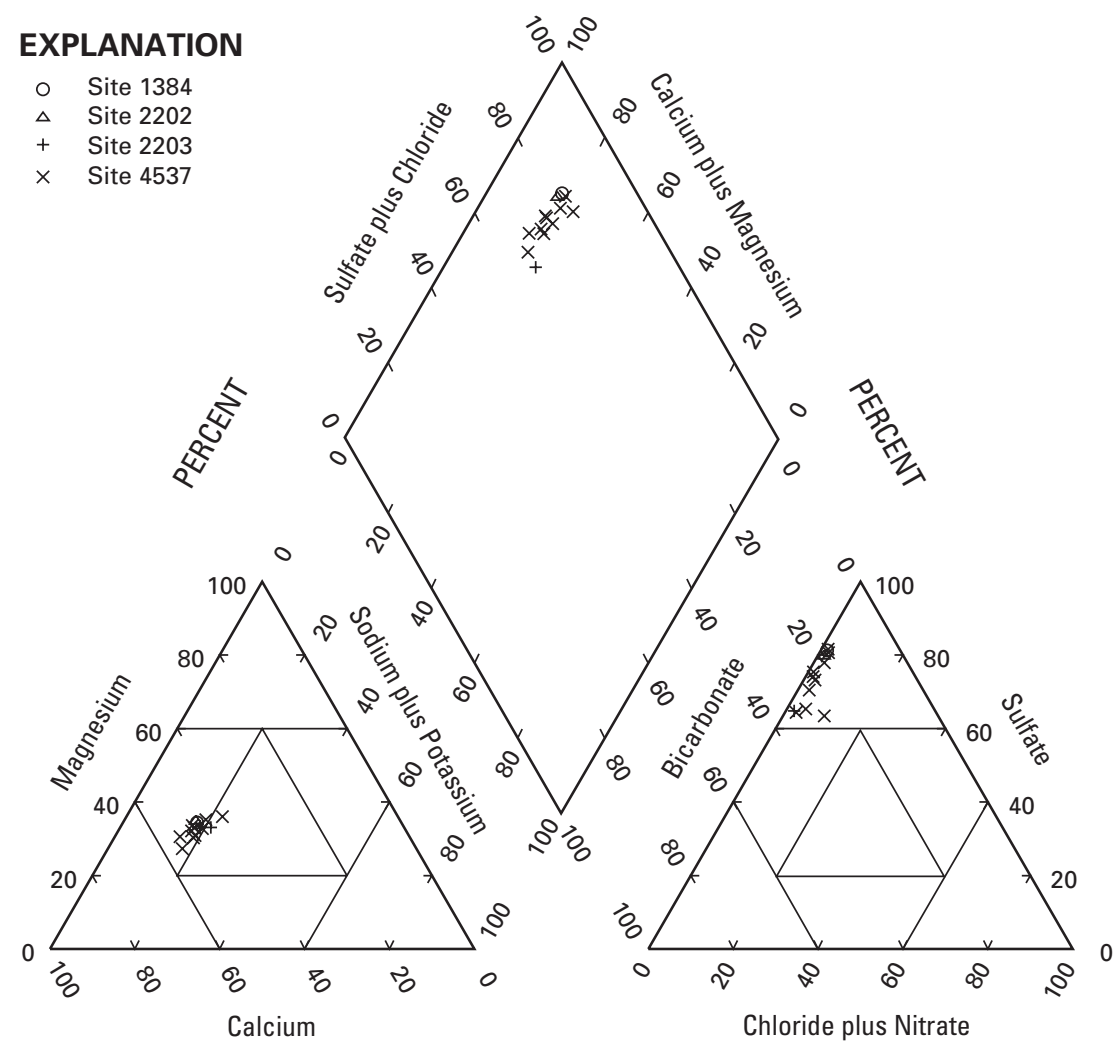

PERCENTAGE OF TOTAL MILLIEQUIVALENTS PER LITER

Figure 18. Water types for selected upstream from and in-park Mancos River sites, Mesa Verde National Park, Colorado, 1975 to 1998.

of the park. Analyses of samples collected six times between 1989 and 1993 from site 4516, which is approximately $10 \mathrm{mi}$ upstream from the park near the town of Mancos, exceeded the TVS for copper (computed as $13.4 \mu \mathrm{g} / \mathrm{L}$ ) with values ranging from 14 to $39 \mu \mathrm{g} / \mathrm{L}$.

Selenium was analyzed 13 times in samples collected between 1975 and 1998 from sites 2202 (1 sample), 2203 (2 samples), and 4537 (10 samples). Selenium concentrations ranged from less than 1 to $15 \mu \mathrm{g} / \mathrm{L}$ with a median value of $4.0 \mu \mathrm{g} / \mathrm{L}$. Three analyses of samples from site 4537 (collected in October 1989, September 1990, and August 1993) with values of 15,5 , and $6 \mu \mathrm{g} / \mathrm{L}$, respectively, and one analysis of a sample from site 2203 with a value of $6 \mu \mathrm{g} / \mathrm{L}$ (collected in July 1994) exceeded the chronic aquatic-life standard for selenium $(4.6 \mu \mathrm{g} / \mathrm{L})$. These two sites are about $0.8 \mathrm{mi}$ upstream from the park's eastern boundary (fig. 17).

Two other Mancos River sites have a trace-element data record of 5 or more years; sites 4522 and 4516, which are approximately 5 and 10 mi upstream from the park boundary, respectively. Trace-metal analyses of samples from these sites indicated periodic exceedances of the aquatic-life standards for filtered copper and silver and total recoverable iron.

Trace elements such as aluminum, copper, iron, zinc, and selenium can enter the water column through natural and anthropogenic sources. In the upper Mancos River watershed, mining and natural gas development activities have the potential to fracture and expose the underlying formations to water and air (for example, dewatering activities resulting in highly mineralized water pumped and combined with surface water), which has the potential to increase trace-element contributions to surface water (Chapman, 1998; Arthur and others, 2003). Coal-bed methane produced water can have elevated concentrations of trace elements such as iron, manganese, and barium (Rawn-Schatzinger and others, 2004). Where anthropogenic influences are absent or minimal, the types and relative concentrations of trace elements in the surface water are related to the geology. Examination of the historical and current mining areas relative to the spatial distribution of elevated traceelement concentrations was beyond the scope of this study. 


\section{Water Quality of Springs}

From 1977 to 1998 , measurements of $\mathrm{pH}$ and SC were made and concentrations of major ions, nutrients (except one site), and trace elements were analyzed in samples from 23 of 26 springs, though the same field properties or constituents were not measured or sampled at all sites (tables 25 and 27; fig. 17). One or more samples for the analyses of inorganic constituents were collected from 22 sites; one or more samples for the analysis of bacteria were collected from 15 sites; and one sample for the analysis of tritium was collected from 1 site. Because of the few water-quality data for springs, this analysis focuses on the four springs with the highest sampling frequency, which includes Spruce Tree House Spring (site 4415), Long House Spring (site 4421), U.S. Highway 160 Spring near park entrance (site 4431), and Morefield Spring (site 5589). For the purpose of this analysis, data were compared to selected stream or ground-water-quality standards, though the State-designated beneficial uses of springs in MEVE were undetermined for this report.

\section{Field Properties}

The $\mathrm{pH}$ values for springs ranged from 4.5 to $8.8 \mathrm{SU}$ and only a few values were outside the 6.5-9.0 SU range defined by CDPHE for cold- and warm-water aquatic life, including four $\mathrm{pH}$ measurements that were lower than the State standard from three springs (table 27). Site 4431, which discharges from the Mancos Shale in the northeastern corner of the park, had two $\mathrm{pH}$ values measured below the State standard. The other two low-pH values were from sites 4421 and 4424.

Specific conductance was measured at all sampled spring sites in the park and ranged from 102 to $19,700 \mu \mathrm{S} / \mathrm{cm}$. The high value of 19,700 $\mu \mathrm{S} / \mathrm{cm}$ was measured in August 1993 at a spring in School Section Canyon (site 4442); all other SC measurements were below $10,000 \mu \mathrm{S} / \mathrm{cm}$. SC was measured only once at this site, so the representativeness of this value for this site cannot be determined, but it was one to two orders of magnitude greater than all other SC measurements made for springs in the park. Higher SC values, ranging from 2,420 to $3,640 \mu \mathrm{S} / \mathrm{cm}$ (site 5589 ) and 6,020 to $8,176 \mu \mathrm{S} / \mathrm{cm}$ (site 4431) are related to the high concentrations of salts, selenium, and sulfate typically found in the Menefee Formation and Mancos Shale, respectively, and lower SC values, ranging from 265 to $420 \mu \mathrm{S} / \mathrm{cm}$ are associated with springs discharging from the Cliff House Sandstone (sites 4415 and 4421).

\section{Major lons}

Variations in water quality and water type reflect the variable geology within the park. Water types were identified for the four sites with more than five samples and are illustrated in figure 19. Spruce Tree House and Long House Springs (sites 4415 and 4421) discharge from the Cliff House Sandstone and are predominantly calcium-bicarbonate type waters. The U.S. Highway 160 Spring (site 4431), which discharges from the Mancos Shale, is predominantly a mixed sodium-sulfate water type with some magnesium. Morefield Spring (site 5589), which discharges from the Menefee Formation, is predominantly a sodium-bicarbonate type water.

\section{Nutrients}

Nitrate (unfiltered) and total phosphorus (filtered) were the only nutrients analyzed in samples collected from the springs in MEVE between 1983 and 1998. Nitrate concentrations from analyses of samples from all springs (excluding site 4433) in MEVE ranged from less than 0.01 to $12 \mathrm{mg} / \mathrm{L}$ with a median concentration of $0.3 \mathrm{mg} / \mathrm{L}$ (table 27). Analyses of eight samples from site 4431, which is near the park entrance and U.S. Highway 160, had the highest median nitrate value of $4.08 \mathrm{mg} / \mathrm{L}$. Site 4438 (Navajo Canyon) also had a high nitrate value of $7.50 \mathrm{mg} / \mathrm{L}$ from one analysis. Analyses of samples from site 4433 (Big Hill Pipes) had three very high nitrate values measured between 1984 and 1995 ranging from 29.9 to $71.4 \mathrm{mg} / \mathrm{L}$ (table 27). These are the only nitrate data available for this site, and they appear anomalously high in comparison to nitrate values from other springs sampled in the park; however, overall ion concentrations from these three samples were high. Without additional nitrate analyses, including quality-control data, it is not possible to determine if these values are representative of unusual conditions at this site or possibly a reporting or laboratory error. These three sites with elevated nitrate concentrations are not near or downstream from the park's three sewage lagoons. No aquatic-life standards exist for nitrate in Colorado; however, when recent data (since 1998) are compared to the Colorado ground-water standard of $10 \mathrm{mg} / \mathrm{L}$, two nitrate values (one each from sites 4431 and 4433) exceeded this standard with values of 12 and $29.9 \mathrm{mg} / \mathrm{L}$, respectively.

Total phosphorus (filtered) concentrations for the same period for all springs ranged from less than 0.10 to $1.6 \mathrm{mg} / \mathrm{L}$ with a median concentration of $0.10 \mathrm{mg} / \mathrm{L}$. No aquatic-life standard exists for total phosphorus in Colorado; however, the USEPA-recommended criterion for the aggregate nutrient Ecoregion III, which includes MEVE, for total phosphorus in rivers and streams, is $0.022 \mathrm{mg} / \mathrm{L}$ (U.S. Environmental Protection Agency, 2002). Of the 49 recent analyses of samples collected from 22 springs in the park, more than one-half (33 analyses) had total phosphorus concentrations greater than this recommended criterion. Analyses of samples from four sites, three in the southwestern part of the park and one in the central area of the park, had total phosphorus concentrations greater than $1.0 \mathrm{mg} / \mathrm{L}$ (sites 4438, 4437, 4442, and 4435); these sites were each analyzed for total phosphorus one time and had concentrations of $1.4,1.6,1.4$, and $1.6 \mathrm{mg} / \mathrm{L}$, respectively. Site 4437 is near the Wetherill Sewage Lagoon in Long Canyon (fig. 17). Elevated phosphorus values may be derived from selected phosphorus-rich minerals such as apatite, from ash and sediment transport following fires, or from sewage lagoons. 
Table 27. Statistical summary of water-quality data and exceedances of water-quality standards for selected springs in Mesa Verde National Park, Colorado, 1977 to 1998.

[CDPHE, Colorado Department of Public Health and Environment; COGW, Colorado ground water (all uses); Cr III, chromium III; DOM, domestic-water system; EPA RC III, U.S. Environmental Protection Agency National Recommended Nutrient Criteria for Ecoregion III; fil, filtered; GM, geometric mean (excludes censored values); H, high; I, instantaneous (grab); L, low (minimum) standard; mg/L, milligrams per liter; MPN, most probable number; N, nitrogen; No., number; P, phosphorus; PCR, primary contact recreation; POR, period of record; unfil, unfiltered; $\mu \mathrm{S} / \mathrm{cm}$, microsiemens per centimeter; <, less than; --, not available; bold type indicates exceedance during recent POR; *, includes data from Big Hill Pipes (site 4433)]

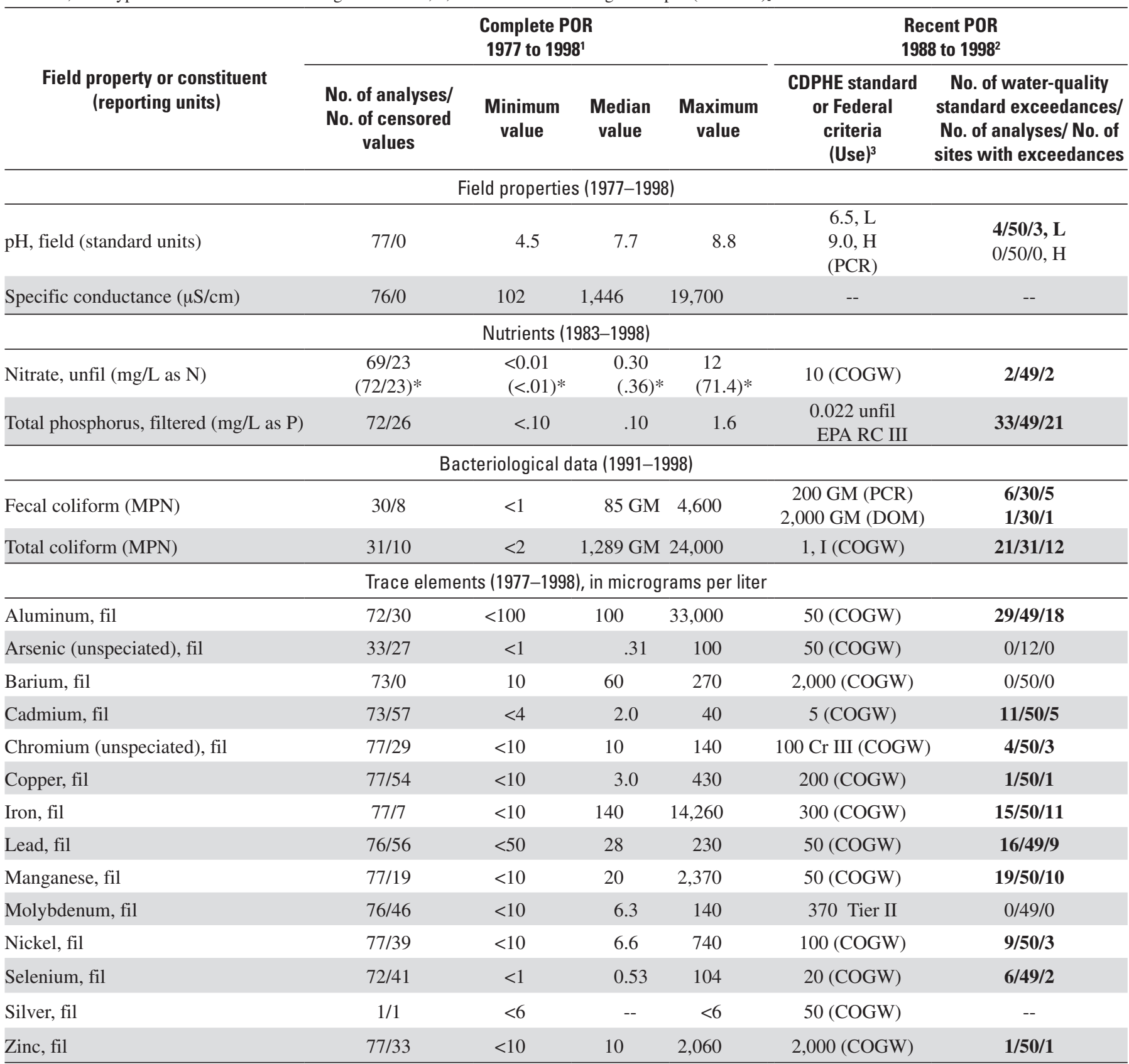

${ }^{1}$ Period of record reflects full range evaluated for all relevant sites within this time period; some sites or constituents may not have had data available for the entire record.

${ }^{2}$ Last 15 years of available data considered for standards exceedance analysis (that is, all samples collected on or after January 1, 1988, through December 31, 2003). At the time of data compilation no data were available from the source databases for the selected sites after 1998.

${ }^{3}$ State standards and designated beneficial uses from Colorado Department of Public Health and Environment (2005). All trace-element standards based on Colorado ground-water standards, where available. Selected Federal criteria are used when State standards are not established, including the USEPA National Recommended Nutrient Criteria for Ecoregions II and III (U.S. Environmental Protection Agency, 2002) or the secondary chronic Tier II values (Suter and Tsao, 1996). 


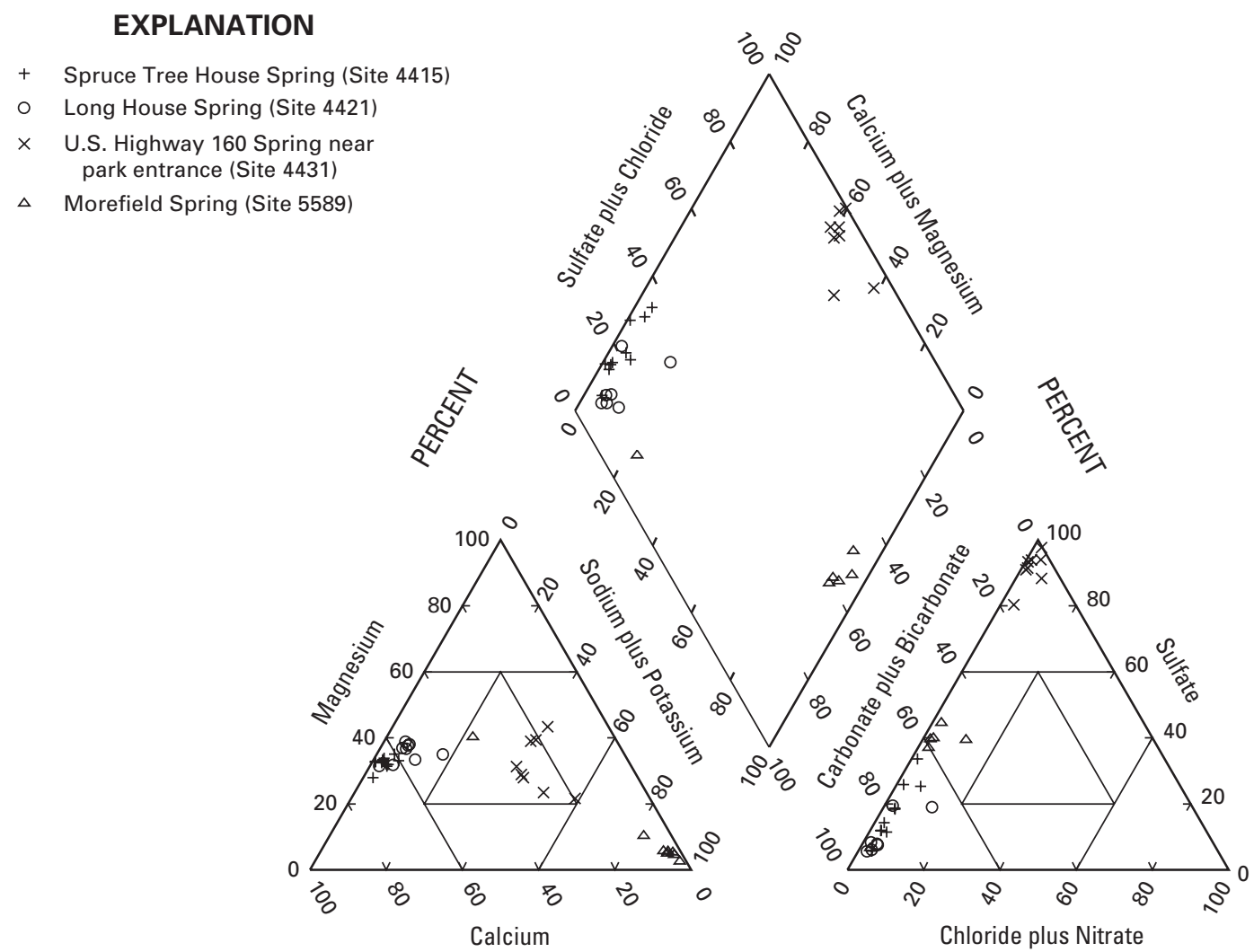

PERCENTAGE OF TOTAL MILLIEQUIVALENTS PER LITER

Figure 19. Water types for the four springs with five or more major ion samples in Mesa Verde National Park, Colorado, 1977 to 1998.

\section{Bacteriological Data}

Between 1991 and 1998, 30 and 31 springs in the park were measured for fecal and total coliform (table 27). Six measurements (from sites 4417, 4430, 4434, 4444, and 5589) exceeded the primary-contact recreation fecal coliform standard of $200 \mathrm{col} / 100 \mathrm{~mL}$ with values ranging from 240 to 4,600 MPN. One value (from site 4434) exceeded the drinking-water supply standard of 2,000 col/100 mL for fecal coliform. More than one-half ( 21 of 31 measurements from 12 sites) of the total coliform values exceeded the Colorado ground-water standard of $1 \mathrm{col} / 100 \mathrm{~mL}$ with values ranging from 21 to 24,000 MPN. The ground-water standard is the only total coliform standard in Colorado. The springs in the vicinity of the sewage lagoons in Soda, Navajo, and Morefield Canyons could be affected by these facilities. Because springs are the principal water source in the park, they are frequented by wildlife, which could be contributing to elevated levels of bacteria in these waters. Visitor access to springs in the park is restricted.
Trace Elements

For the springs, analyses for 12 filtered trace elements (aluminum, barium, cadmium, chromium, copper, iron, lead, manganese, molybdenum, nickel, selenium, and zinc) were completed for 72 to 77 samples collected between 1977 and 1998 from 50 to 57 sites (table 27). Additionally, samples were analyzed for filtered arsenic 33 times (from 20 sites), and once for filtered silver (from site 4446). Since 1988, analyses of samples for selected trace elements from four springs (sites 4415, 4431, 4421, and 5589; fig. 17) were made between six and nine times; the remaining sites were only sampled and analyzed for trace elements once or twice during this same time period. For analyses of samples collected from springs between 1988 and 1998, some trace-element concentrations exceeded the 30-day chronic aquatic warm-water standards and the Colorado ground-water standard. Of the 14 traceelements analyzed, exceedances of all but arsenic, barium, molybdenum, and silver occurred in one or more samples collected since 1988. 
For all springs, the filtered aluminum concentrations ranged from less than 100 to $33,000 \mu \mathrm{g} / \mathrm{L}$ with a median of $100 \mu \mathrm{g} / \mathrm{L}$. Two extreme values were recorded in samples from site $5589(30,900$ and 33,000 $\mu \mathrm{g} / \mathrm{L}$ in 1995 and 1998, respectively) and one from site 4431 (20,800 $\mu \mathrm{g} / \mathrm{L}$ in 1989); all other values were less than $7,700 \mu \mathrm{g} / \mathrm{L}$. No quality-control data were available to verify these high concentrations, and other trace-element analyses of samples collected from these sites showed filtered aluminum concentrations one to two orders of magnitude lower. Analyses of aluminum in samples from three additional sites (sites 4424, 4437, and 4438) had values of 900, 4,400, and 1,400 mg/L, respectively. All other recorded values for aluminum were one to two orders of magnitude smaller. Discharge from three of these sites (sites 4437, 4438, and 5589) comes from the Menefee Formation, discharge from one site (site 4424) comes from the Cliff House Sandstone, and discharge from one site (site 4431) comes from the Mancos Shale near the park entrance and U.S. Highway 160. Twenty-nine exceedances of the State's ground-water standard for aluminum $(50 \mu \mathrm{g} / \mathrm{L})$ were identified at 18 spring sites located throughout various ephemeral drainages in the park. Of these, analyses for aluminum in samples from three sites $(5589,4431$, and 4421) showed repeated exceedances of the State chronic aquatic-life standard. Water with low $\mathrm{pH}$ (below 4.0 SU) can contain elevated aluminum concentrations (Hem, 1989); however, only one of the elevated aluminum values $(30,800 \mathrm{mg} / \mathrm{L}$ measured in a sample from site 4431 in 1989) corresponds to low pH (4.6 SU). The inclusion of aluminum-rich particulate material, which can pass through some filter media, can lead to elevated aluminum values that can be erroneously reported as part of the dissolved phase in the sample (Hem, 1989). Filter size was not available for the historical water-quality data.

The filtered cadmium concentrations ranged from less than 4 to $40 \mu \mathrm{g} / \mathrm{L}$ with a median of $2.0 \mu \mathrm{g} / \mathrm{L}$ in trace-element analyses of samples collected between 1977 and 1998.

Analyses of samples from five sites (5589, 4431, 4433, 4435, and 4442) exceeded the ground-water standard of $5 \mu \mathrm{g} / \mathrm{L}$; analyses of samples from two of these sites (Morefield and U.S. Highway 160 Springs) indicated repeated exceedances of this standard. One or more concentrations measured in three springs (sites 4431, 4435, and 5589) were greater than $10 \mu \mathrm{g} / \mathrm{L}$ in analyses of samples collected from 1987 to 1998. Discharge from each of these sites comes from a different geologic formation.

The filtered "total" (unspeciated) chromium concentrations ranged from less than 10 to $140 \mu \mathrm{g} / \mathrm{L}$ with a median value of $10 \mu \mathrm{g} / \mathrm{L}$ in trace-element analyses of samples collected from 1977 to 1998 . The ground-water standard for trivalent chromium is $100 \mu \mathrm{g} / \mathrm{L}$; analyses of four samples (from sites 4431, 4433, and 4434) exceeded this standard for samples collected since 1987.

Filtered copper concentrations ranged from less than 10 to $430 \mu \mathrm{g} / \mathrm{L}$ with a median of $3.0 \mu \mathrm{g} / \mathrm{L}$ in trace-element analyses of samples collected between 1977 and 1998. Two elevated copper concentrations, 131 and $430 \mu \mathrm{g} / \mathrm{L}$, measured in 1977 and 1991, respectively, were measured in samples from two sites (4449 and 4435, respectively). The 1991 value from site 4435 exceeded the ground-water standard of $200 \mu \mathrm{g} / \mathrm{L}$. All other copper concentrations measured in samples from springs in the park were at or below $24 \mu \mathrm{g} / \mathrm{L}$.

Filtered iron concentrations typically ranged from less than 10 to 2,690 $\mu \mathrm{g} / \mathrm{L}$. Analyses of samples collected from Morefield Spring (site 5589) had two extreme values of 8,360 and 14,260 $\mu \mathrm{g} / \mathrm{L}$ measured in 1995 and 1998, respectively. The Colorado ground-water standard for iron is $300 \mu \mathrm{g} / \mathrm{L}$; analyses of 15 samples (from 11 sites) collected between 1988 and 1998 had concentrations exceeding this standard. Iron, like aluminum, can have colloidal properties pass through a filter and be reported erroneously as "dissolved" (Hem, 1989).

The filtered lead concentrations ranged from less than 50 to $230 \mu \mathrm{g} / \mathrm{L}$ with a median of $28 \mu \mathrm{g} / \mathrm{L}$. Analyses of samples collected from seven sites scattered throughout the ephemeral drainages of the park had one exceedance of the Colorado ground-water standard of $50 \mu \mathrm{g} / \mathrm{L}$; analyses of samples from two sites (sites 4431 and 5589) had seven and two exceedances, respectively. Analyses of samples collected from three of these springs (sites 4431, 4442, and 4433), which discharge from the Mancos Shale and Menefee Formation, had elevated lead values greater than $100 \mu \mathrm{g} / \mathrm{L}$.

Filtered manganese concentrations ranged from less than 10 to $2,370 \mu \mathrm{g} / \mathrm{L}$ with a median value of $20 \mu \mathrm{g} / \mathrm{L}$ in trace-element analyses of samples collected from 1977 to 1998. The Colorado ground-water standard for manganese is $50 \mu \mathrm{g} / \mathrm{L}$. Nineteen analyses of recently collected samples from 10 sites exceeded this standard. Based on analyses of eight samples collected from 1987 to 1998, manganese concentrations measured from site 4431-which discharges from the Mancos Shale-are, on average, the highest in the park with a range of values 490 to $2,370 \mu \mathrm{g} / \mathrm{L}$. Concentrations of manganese and iron can be elevated under low DO conditions typical of springs and ground water.

Filtered nickel concentrations ranged from less than 10 to $740 \mu \mathrm{g} / \mathrm{L}$ with a median of $6.6 \mu \mathrm{g} / \mathrm{L}$ in trace-element analyses of samples collected from 1977 to 1998. Analyses of nine samples from three sites (sites 4431, 4433 and 4442) exceeded the Colorado ground-water standard of $100 \mu \mathrm{g} / \mathrm{L}$. Nickel analyses of samples collected from the U.S. Highway 160 Spring (site 4431) indicated seven exceedances of this standard.

Filtered selenium concentrations ranged from less than 1 to $104 \mu \mathrm{g} / \mathrm{L}$ with a median of $0.53 \mu \mathrm{g} / \mathrm{L}$. Analyses of samples collected from two springs (sites 4431 and 4433) exceeded the State ground-water standard for selenium $(20 \mu \mathrm{g} / \mathrm{L})$ one or more times; analyses of samples from the U.S. Highway 160 Spring (site 4431) exceeded this selenium standard five times, which are likely attributable to natural selenium sources within the Mancos Shale.

Filtered zinc concentrations generally ranged from less than 10 to $840 \mu \mathrm{g} / \mathrm{L}$ with a median of $10 \mu \mathrm{g} / \mathrm{L}$. One elevated zinc value $(2,060 \mu \mathrm{g} / \mathrm{L})$ was recorded in analysis of a sample collected from site 4434 in September 1988, which exceeded the Colorado ground-water standard of 2,000 $\mu \mathrm{g} / \mathrm{L}$. One other 
analysis of zinc, in a sample collected from this site approximately one year earlier (in October 1987), was measured at $50 \mu \mathrm{g} / \mathrm{L}$. No other zinc analyses exceeded this standard.

\section{Summary of Surface-Water and Springs Characterization and Considerations for Monitoring}

The Mancos River data are generally sparse, and the sites within and directly upstream from the park were sampled only once in October 1975 (sites 1384 and 2202) or twice in March and July 1994 (site 2203). One site was sampled multiple times between 1986 and 1998 (site 4357); however, no streamflows were measured. The river increases in dissolved ions, particularly calcium and sulfate, as it flows from the town of Mancos, along the park boundary, and downstream from the park toward Johnson Canyon, indicating an increasing effect of drainage from Mancos Shale and Menefee Formation terrains. Concentrations of aluminum, selenium, and zinc exceeded the State standards one or more times at the sites in or just upstream from the park. These elevated concentrations could be related to upstream geology or to anthropogenic activities such as agricultural or mining activities; however, current water-quality data are needed to determine if these constituents are present at concentrations exceeding State standards or Federal criteria. A focused waterquality study, including nutrients, trace elements, and currently and historically used herbicides and sampled across different aquatic environment media, including sediment and fish tissue, would be useful to determine if these potential constituents are contributing to the degraded macroinvertebrate and reduced fish population in the Mancos River.

The quality of the water discharging from springs in Mesa Verde National Park appears to be controlled primarily by the surrounding geologic formations, resulting in elevated concentrations of nutrients, major ions, and selected trace elements. Concentrations of aluminum, cadmium, chromium, copper, iron, lead, nickel, selenium, and zinc each exceeded their respective water-quality standard one or more times. Aluminum concentrations were particularly high in samples from sites 4431 and 5589 and may warrant a focused study to evaluate the source. Elevated concentrations of nitrogen and phosphorus could be related to surrounding geology (phosphorus), to fire effects, or to activities within or upgradient from the park, including the sewage lagoons in the park. Two springs were identified as having elevated concentrations of multiple constituents, including site 4431 (near the park entrance and U.S. Highway 160) and site 5589 (Morefield Spring in Morefield Canyon). Analyses of samples from site 4433, Big Hill Pipes, indicated elevated concentrations of nutrients and selenium, which could be related to upgradient agricultural activities or geology. Nitrogen levels for this site were anomalously high and may well be a reporting or analytical error. The inconsistency and paucity of the data limit the ability to compare the water quality of these springs to identified management concerns. Measurements of $\mathrm{pH}$ and analyses of samples for nutrients and trace elements are suggested for any future water-quality monitoring of springs. Comparison to ground-water data from this area could help identify if sources of elevated constituent concentrations were related to geology or surrounding land-use activities.

\section{Synthesis of Surface-Water Characterization and Implications for Future Water-Quality Monitoring Activities}

Although each park unit is charged with managing its own natural resources, including water, the SCPN and national NPS offices also have an interest in the regional or national water-quality issues that may be of concern to multiple parks. In order to address this interest, the total number of exceedances (by park) of applicable State standards and uses or Federal criteria are summarized in table 28 for stream sites sampled between 1988 and 2003 in BAND, CACH, CHCU, GLCA, and MEVE.

From this summary it is evident that many field properties and constituents are not measured or sampled regularly enough to determine if exceedance of State standards or Federal criteria is a chronic occurrence in these surface waters. Field properties or constituents with 20 or more measurements or samples per park and an overall exceedance rate of 25 percent or higher indicate recurring exceedances in data collected between 1988 and 2003. These include low dissolved oxygen concentrations in CACH and GLCA (in Arizona); elevated turbidity levels through the Utah and Arizona sections of GLCA; elevated nitrogen (unfiltered) concentrations in $\mathrm{CHCU}$; elevated total phosphorus (unfiltered) concentrations in BAND, CACH, CHCU, and GLCA (both Arizona and Utah); elevated barium (filtered) concentrations in GLCA (both Arizona and Utah); and elevated mercury concentrations in CHCU. These field properties and constituents are suggested candidates for additional water-quality monitoring in the specified parks. Selected constituents exhibited percent exceedances higher than 25 percent; however, the total numbers of analyses are too few to determine if the exceedances are a regular occurrence. These sparse data, including total phosphorus (filtered) in MEVE, Escherichia coli in $\mathrm{CACH}$, fecal coliform in MEVE, suspended solids in $\mathrm{CACH}$, aluminum (filtered) in $\mathrm{CHCU}$ and MEVE, copper (filtered) in CHCU, and selenium (filtered) in MEVE also are potential candidates for more frequent monitoring to determine if they may indicate a water-quality concern. On a network scale and based on the characterization of water-quality data from these five parks, it would be useful for future SCPN water-quality monitoring plans to include measurements of $\mathrm{pH}$ and DO and analyses of samples for nutrients, turbidity (that is, suspended sediment), and selected trace elements including aluminum, copper, selenium, and possibly mercury. Routine monitoring for these field properties or constituents to establish a baseline and track changes in water quality would 
Table 28. Summary of water-quality standard exceedances by park for stream sites for five Southern Colorado Park Network park units, Arizona, Colorado, New Mexico, and Utah, 1988-2003.

[AL, aquatic life; ALW2, aquatic-life warm-water class 2 (CO); AWC, aquatic and wildlife cold water (AZ); AWW, aquatic and wildlife warm water (AZ); AZ, Arizona; BAND, Bandelier National Monument; CACH, Canyon de Chelly National Monument; CHCU, Chaco Culture National Historical Park; CO, Colorado; col/100 mL, colonies per 100 milliliters; deg C, degrees Celsius; EPA RC II/III, U.S. Environmental Protection Agency National Recommended Nutrient Criteria for Ecoregion II/III; FBC, full-body contact (AZ); fil, filtered; GLCA, Glen Canyon National Recreation Area; GM, geometric mean; H, high (maximum) standard; HQCF, high-quality cold-water fishery (NM); L, low (minimum) standard; LW, livestock watering; MEVE, Mesa Verde National Park; mg/L, milligrams per liter; MPN/100 mL, most probable number per 100 milliliters; N, nitrogen; NAWQ, National Ambient Water Quality; NM, New Mexico; No., number; P, phosphorus; PC, primary contact (NM); PCR, primary-contact recreation (CO); SS, suspended sediment; TVS, table value standard; TVS 100, table value standard computed using a hardness of $100 \mathrm{mg} / \mathrm{L} \mathrm{CaCO}$ (provided as a baseline for comparison, site-specific TVS used for exceedance analysis); unfil, unfiltered; UT, Utah; WF, warm-water fishery (NM); 2B, secondary-contact recreation (UT); 3A, aquatic-life cold (UT); 3B, aquatic-life warm (UT); 3C, aquatic-life support (UT); 30 dav, 30-day average; <, less than; --, not available; bold type indicates percent exceedance greater than 25 percent for 20 or more analyses per park; italicized text indicates percent exceedance greater than 25 percent for fewer than 20 analyses per park; data for CHCU are from 1976 to 1983]

\begin{tabular}{llcc}
$\begin{array}{l}\text { Park } \\
\text { (State[s]) }\end{array}$ & $\begin{array}{l}\text { Field property } \\
\text { or constituent } \\
\text { (reporting units) }\end{array}$ & $\begin{array}{c}\text { State standard } \\
\text { or Federal criteria (Use) }\end{array}$ & $\begin{array}{c}\text { No. of exceedances/No. of } \\
\text { analyses/No. of sites with } \\
\text { exceedances (1988-2003) }\end{array}$ \\
\hline
\end{tabular}

Percentage of exceedances per total no. of analyses

\begin{tabular}{ll}
\hline BAND (NM) & Dissolved oxygen $(\mathrm{mg} / \mathrm{L})$ \\
CACH (AZ) & Dissolved oxygen $(\mathrm{mg} / \mathrm{L})$
\end{tabular}

Field measurements

GLCA (AZ, UT) Dissolved oxygen (mg/L)

6 (HQCF)
7 min (AWC)
6.5 (UT 3A, $30 \mathrm{dav})$
5.5 (UT 3B, 30 dav)
6 (AZ AWW)

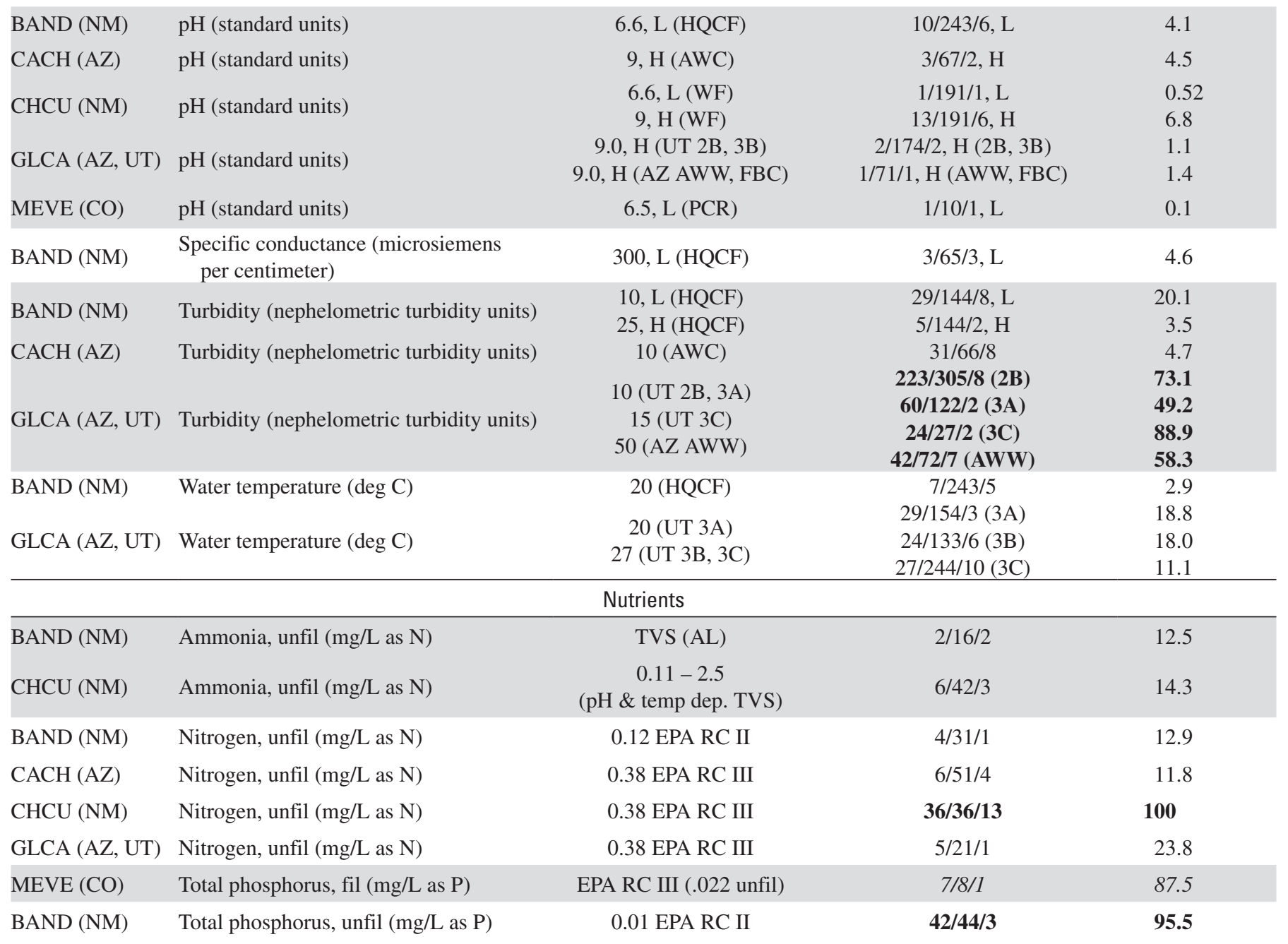


Table 28. Summary of water-quality standard exceedances by park for stream sites for five Southern Colorado Park Network park units, Arizona, Colorado, New Mexico, and Utah, 1988-2003.-Continued

[AL, aquatic life; ALW2, aquatic-life warm-water class 2 (CO); AWC, aquatic and wildlife cold water (AZ); AWW, aquatic and wildlife warm water (AZ); AZ, Arizona; BAND, Bandelier National Monument; CACH, Canyon de Chelly National Monument; CHCU, Chaco Culture National Historical Park; CO, Colorado; col/100 mL, colonies per 100 milliliters; deg C, degrees Celsius; EPA RC II/III, U.S. Environmental Protection Agency National Recommended Nutrient Criteria for Ecoregion II/III; FBC, full-body contact (AZ); fil, filtered; GLCA, Glen Canyon National Recreation Area; GM, geometric mean; H, high (maximum) standard; HQCF, high-quality cold-water fishery (NM); L, low (minimum) standard; LW, livestock watering; MEVE, Mesa Verde National Park; mg/L, milligrams per liter; MPN/100 mL, most probable number per 100 milliliters; N, nitrogen; NAWQ, National Ambient Water Quality; NM, New Mexico; No., number; P, phosphorus; PC, primary contact (NM); PCR, primary-contact recreation (CO); SS, suspended sediment; TVS, table value standard; TVS 100, table value standard computed using a hardness of $100 \mathrm{mg} / \mathrm{L} \mathrm{CaCO}_{3}$ (provided as a baseline for comparison, site-specific TVS used for exceedance analysis); unfil, unfiltered; UT, Utah; WF, warm-water fishery (NM); 2B, secondary-contact recreation (UT); 3A, aquatic-life cold (UT); 3B, aquatic-life warm (UT); 3C, aquatic-life support (UT); 30 dav, 30-day average; <, less than; --, not available; bold type indicates percent exceedance greater than 25 percent for 20 or more analyses per park; italicized text indicates percent exceedance greater than 25 percent for fewer than 20 analyses per park; data for CHCU are from 1976 to 1983]

$\begin{array}{lccc}\text { Park } & \text { Field property } & \text { State standard } & \text { No. of exceedances/No. of } \\ \text { or constituent } & \text { analyses/No. of sites with } \\ \text { (State[s]) } & \text { exceedances (1988-2003) }\end{array}$

Percentage of exceedances per total no. of analyses

\begin{tabular}{|c|c|c|c|c|}
\hline \multicolumn{5}{|c|}{ Nutrients-Continued } \\
\hline CHCU (NM) & Total phosphorus, unfil (mg/L as P) & 0.022 EPA RC III & $43 / 45 / 12$ & 95.6 \\
\hline \multicolumn{5}{|c|}{ Bacteriological data } \\
\hline BAND (NM) & Fecal coliform (col/100 mL) & 200, GM (PC) & 4/33/4, GM & 12.1 \\
\hline MEVE (CO) & Fecal coliform (MPN) & 200, GM (PCR) & $4 / 7 / 1, G M$ & 57.1 \\
\hline \multicolumn{5}{|c|}{ Other constituents } \\
\hline $\mathrm{CACH}(\mathrm{AZ})$ & Chlorine, total residual (mg/L) & .005 (AWC) & $1 / 15 / 1$ & 6.7 \\
\hline CHCU (NM) & Aluminum, fil & 87 fil (AL) & $5 / 12 / 4$ & 41.7 \\
\hline GLCA (AZ, UT) & Aluminum, fil & 87 fil (UT 3A, 3B, 3C) & $\begin{array}{c}2 / 33 / 1(3 \mathrm{~A}) \\
14 / 71 / 7(3 \mathrm{~B}) \\
12 / 92 / 4(3 \mathrm{C})\end{array}$ & $\begin{array}{r}6.1 \\
19.7 \\
13.0\end{array}$ \\
\hline $\operatorname{MEVE}(\mathrm{CO})$ & Aluminum, fil & ALW2 (87) & $5 / 8 / 1$ & 62.5 \\
\hline CHCU (NM) & Barium, fil & 4 fil Tier II & $16 / 70 / 8$ & 22.9 \\
\hline GLCA (AZ, UT) & Barium, fil & 4 fil Tier II & 291/291/32 & 100 \\
\hline CHCU (NM) & Beryllium, fil & 5.3 fil (AL) & $1 / 14 / 1$ & 7.1 \\
\hline GLCA (AZ, UT) & Beryllium, fil & 5.3 fil (AZ AWW) & $6 / 70 / 4$ & 8.6 \\
\hline $\operatorname{MEVE}(\mathrm{CO})$ & Iron, fil & NAWQ $(1,000)$ & $1 / 8 / 1$ & 12.5 \\
\hline GLCA (AZ, UT) & Lead, fil & 3.2 fil (UT TVS 100) & $8 / 190 / 6$ & 4.2 \\
\hline
\end{tabular}


Table 28. Summary of water-quality standard exceedances by park for stream sites for five Southern Colorado Park Network park units, Arizona, Colorado, New Mexico, and Utah, 1988-2003.-Continued

[AL, aquatic life; ALW2, aquatic-life warm-water class 2 (CO); AWC, aquatic and wildlife cold water (AZ); AWW, aquatic and wildlife warm water (AZ); AZ, Arizona; BAND, Bandelier National Monument; CACH, Canyon de Chelly National Monument; CHCU, Chaco Culture National Historical Park; CO, Colorado; col/100 mL, colonies per 100 milliliters; deg C, degrees Celsius; EPA RC II/III, U.S. Environmental Protection Agency National Recommended Nutrient Criteria for Ecoregion II/III; FBC, full-body contact (AZ); fil, filtered; GLCA, Glen Canyon National Recreation Area; GM, geometric mean; H, high (maximum) standard; HQCF, high-quality cold-water fishery (NM); L, low (minimum) standard; LW, livestock watering; MEVE, Mesa Verde National Park; mg/L, milligrams per liter; MPN/100 mL, most probable number per 100 milliliters; N, nitrogen; NAWQ, National Ambient Water Quality; NM, New Mexico; No., number; P, phosphorus; PC, primary contact (NM); PCR, primary-contact recreation (CO); SS, suspended sediment; TVS, table value standard; TVS 100, table value standard computed using a hardness of $100 \mathrm{mg} / \mathrm{L} \mathrm{CaCO}$ (provided as a baseline for comparison, site-specific TVS used for exceedance analysis); unfil, unfiltered; UT, Utah; WF, warm-water fishery (NM); 2B, secondary-contact recreation (UT); 3A, aquatic-life cold (UT); 3B, aquatic-life warm (UT); 3C, aquatic-life support (UT); 30 dav, 30-day average; <, less than; --, not available; bold type indicates percent exceedance greater than 25 percent for 20 or more analyses per park; italicized text indicates percent exceedance greater than 25 percent for fewer than 20 analyses per park; data for CHCU are from 1976 to 1983]

\begin{tabular}{llcc}
\hline $\begin{array}{l}\text { Park } \\
\text { (State[s]) }\end{array}$ & $\begin{array}{l}\text { Field property } \\
\text { or constituent } \\
\text { (reporting units) }\end{array}$ & $\begin{array}{c}\text { State standard } \\
\text { or Federal criteria (Use) }\end{array}$ & $\begin{array}{c}\text { No. of exceedances/No. of } \\
\text { analyses/No. of sites with } \\
\text { exceedances (1988-2003) }\end{array}$ \\
\hline
\end{tabular}

\begin{tabular}{|c|c|c|c|c|}
\hline \multicolumn{5}{|c|}{ Trace elements (Results reported in micrograms per liter)—Continued } \\
\hline $\mathrm{CHCU}(\mathrm{NM})$ & Manganese, fil & 120 fil Tier II & $4 / 79 / 2$ & 5.1 \\
\hline GLCA (AZ, UT) & Manganese, fil & 120 fil Tier II & $52 / 269 / 10$ & 19.3 \\
\hline $\mathrm{CHCU}(\mathrm{NM})$ & Mercury, unfil recoverable & 0.012 unfil (AL) & $45 / 55 / 12$ & 81.8 \\
\hline $\operatorname{MEVE}(\mathrm{CO})$ & Selenium, fil & ALW2 (4.6) & $4 / 10 / 2$ & 40 \\
\hline CHCU (NM) & Selenium, unfil recoverable & 5 unfil rec $(\mathrm{AL})$ & $11 / 67 / 3$ & 16.4 \\
\hline $\mathrm{CACH}(\mathrm{AZ})$ & Silver, fil & TVS (AWC) & $1 / 12 / 1$ & 8.3 \\
\hline $\mathrm{CHCU}(\mathrm{NM})$ & Uranium (natural), fil & 2.6 fil Tier II & $5 / 27 / 5$ & 18.5 \\
\hline
\end{tabular}

Radiological constituents (Results reported in picocuries per liter)

\begin{tabular}{llcl}
\hline $\mathrm{CHCU}(\mathrm{NM})$ & $\begin{array}{l}\text { Gross alpha radioactivity, natural uranium } \\
\text { curve, fil }\end{array}$ & $15(\mathrm{LW})$ & $3 / 14 / 3$ \\
\hline
\end{tabular}

\footnotetext{
${ }^{1}$ Designated beneficial uses and standards from the Colorado Department of Public Health and Environment (2002a), State of Utah Department of Environmental Quality (2005), the Arizona Department of Environmental Quality (State of Arizona, 2002), or the New Mexico Water Quality Control Commission (State of New Mexico, 2002). Selected Federal criteria are used when State standards are not established, including the USEPA National Recommended Nutrient Criteria for Ecoregions II and III (U.S. Environmental Protection Agency, 2002), the National Ambient Water Quality criteria (NAWQ), or the secondary chronic Tier II values (Suter and Tsao, 1996).
} 
help determine if historical elevated values identified in these five parks are a persistent or emerging water-quality concern throughout parks in the network.

It would be helpful to consider the State standard or Federal criteria used to evaluate these data within the context of each park's geology and environmental setting. The incidents of percent exceedances in excess of 80 percent (for example, barium in GLCA) may indicate that the standard or criterion used is too low for the expected background conditions found in these surface waters, or it may indicate a persistent waterquality concern. Regular long-term water-quality monitoring is necessary to determine a baseline condition for these waters without which degradation or improvement over time cannot be determined. Three principal issues identified from the characterization of water-quality data for these parks ought to be considered for future water-quality monitoring: analysis of data at censoring levels below applicable State water-quality standards or Federal criteria, corresponding measurement of streamflow (or spring discharge) with samples, and collection of samples over the entire annual hydrologic cycle rather than just during one season of the calendar or water year.

\section{Summary}

Historical natural-resource monitoring data, including water-quality data, in the National Park Service Southern Colorado Plateau Network have been collected irregularly and commonly have lacked corresponding interpretation, all of which has restricted the use of the data. Increased pressures from surrounding land-use activities coupled with substantial increases in the number of recreational visitors present the parks with numerous resource-management challenges. In 1999, the National Park Service initiated the Inventory and Monitoring Program as part of the 1998 National Parks Omnibus Management Act, which was designed to establish natural-resource inventory and monitoring as standard practices within the National Park Service in order to provide a scientific basis for sound park management. To help address these issues, to inform future water-quality monitoring planning efforts, and to address relevant National Park Service Inventory and Monitoring Program objectives, the U.S. Geological Survey, in cooperation with the National Park Service, compiled, reviewed, and summarized available historical (1925 to 2004) water-quality data for 19 park units in the Southern Colorado Plateau Network in northern Arizona, southwestern Colorado, northwestern New Mexico, and southern Utah. These parks, which were established for their unique and significant cultural and (or) natural resources, include 3 national parks, 13 national monuments, 1 national historic site, 1 national historical park, and 1 national recreation area. The 19 park units range in size from about 34 acres to greater than 1.2 million acres and total almost 2.9 million acres. Water-quality stressors frequently identified as part of the Phase I and II activities of the National Park Service Inventory and Monitoring Program included erosion, extreme weather events, water withdrawals, trespass grazing, urban development, and invasive exotics.

The National Park Service Southern Colorado Plateau Network and the U.S. Geological Survey cooperated in acquisition, organization, management, and synthesis of available water-quality data associated with the waters of the Southern Colorado Plateau Network parks as part of the Inventory and Monitoring Program activities. Electronically available waterquality data were retrieved (as recently collected as January 2004) for sampling sites located within, adjacent to, and upstream from the 19 park areas. Within the boundaries of the 19 park units, water-quality data were retrieved for 602 sites: 160 streams or rivers, 160 springs, 207 ponds, lakes or reservoirs, 70 water wells, 3 outfalls, and 2 diversions. Approximately 2,306 different field properties or constituents were included in the retrieval. The period of record, data collected, and sampling agencies varied among water-quality sites, and many sites had data for only one or a few samples. Sampling methodology, analytical methods, and quality assurance were not available for much of the historical data, which limited data comparability and interpretation.

The water-quality data collected within the boundaries of the 19 park units were described in terms of availability by major water-quality constituent classes, park unit, site type (that is, streams, springs, lakes [including reservoirs, ponds or pools], and ground-water sites), and selected identified water sources. Park units were classified as "data rich" or "data poor" based on the number and type of samples and the period of record to provide a general categorization of available water-quality data for individual parks. Data-poor parks were those with fewer than 10 samples for any given site type and data-rich parks included parks with greater than 100 water-quality samples for any given site type. Data-poor parks for all site types included Aztec Ruins National Monument, Petroglyph National Monument, Rainbow Bridge National Monument, Sunset Crater Volcano National Monument, Walnut Canyon National Monument, and Yucca House National Monument. Park units with between 10 and 100 samples for one or more site types included Canyon de Chelly National Monument, El Malpais National Monument, El Morro National Monument, Hubbell Trading Post National Historic Site, Navajo National Monument, Petrified Forest National Park, Salinas Pueblo Missions National Monument, and Wupatki National Monument. Data-rich parks with more than 100 samples for one or more site types included Bandelier National Monument, Chaco Culture National Historical Park, Glen Canyon National Recreation Area, Grand Canyon National Park, and Mesa Verde National Park. Most of the water-quality data collected fell within five constituent classes: field properties (8,692 samples), major ions (5,627 samples), nutrients $(4,403$ samples), bacteriological data (3,409 samples), and trace elements (3,305 samples) and most of the data were for stream and spring sites. The exception was Glen Canyon National Recreation Area, which had a large amount of lake data for Lake Powell. 
The report also describes the geology, water resources, water-quality issues, data gaps, and water-quality standard exceedances identified in five of the park units determined to be of high priority. The five park units are Bandelier National Monument in New Mexico, Canyon de Chelly National Monument in Arizona, Chaco Culture National Historical Park in New Mexico, Glen Canyon National Recreation Area in Arizona and Utah, and Mesa Verde National Park in Colorado

Statistical summaries of water-quality characteristics were presented and considerations for future water-quality monitoring were provided for these five park units. For these five park units, the field properties analyzed for this report were acid neutralizing capacity, dissolved oxygen, $\mathrm{pH}$, specific conductance, turbidity, and water temperature. Constituent classes analyzed include major ions, nutrients, trace elements, and bacteriological data. Selected additional constituent classes (for example, radiological constituents or synthetic organic compounds) were mentioned where relevant to a particular park's available water-quality data. Streamflow data were summarized, where available. Water-quality data are strongly site-dependent, and results were assessed within this context, especially when a water body was characterized on the basis of a small number of sampling points. For the purpose of identifying the levels of water-quality field properties or constituents that maybe of concern to individual parks and the Southern Colorado Plateau Network, recent (1988 to 2003) water-quality data were evaluated relative to applicable State or Federal water-quality standards or criteria for sites located within or near to park boundaries for water bodies of interest identified by Southern Colorado Plateau Network personnel as high priority. Not all available waterquality data were evaluated (for example, ground water). Chaco Culture National Historical Park did not have any recent data, and historical data (1976 to 1983) were used to characterize the water quality in this park. In most cases, chronic aquatic-life and (or) primary- or secondary-recreation standards were used to evaluate water-quality data collected in evaluated waters due to the importance of ecological integrity and recreation to the National Park Service. Occasionally, livestock watering, domestic water-supply, or drinking-water standards were used for comparing water quality of springs or other water-quality data to State standards when no aquaticlife or recreation standards applied. Additional analyses included the use of trilinear (Piper) diagrams to characterize the chemical composition of selected water bodies and comparison of relative concentrations of selected constituents between sampling sites. A synthesis of the five park units' water-quality characteristics and implications for future waterquality monitoring activities were also presented.

Bandelier National Monument is in north-central New Mexico on the eastern slopes of the Sierra de los Valles and Pajarito Plateau. The monument is composed of two areas: the main section is south and southwest of Los Alamos National Laboratory and the smaller 800-acre Tsankawi section is southeast of Los Alamos National Laboratory. Bandelier National Monument includes the perennial Rito de los Frijoles
(Upper and Lower Frijoles Creek) and five other major northnorthwest- to south-southeast-draining canyons, including the Lummis, Alamo, Capulin, Medio, and Sanchez Canyons. These canyons receive base flow from springs that discharge along the mountain and plateau interface and drain to the Rio Grande and Cochiti Lake. A 5.5-mi reach of the Rio Grande flows along the southwestern border of the monument and captures all of the drainage from the canyons; however, only the west bank and associated riparian area are within Bandelier's boundaries.

The 1977 La Mesa Fire, the 1996 Dome Fire, and the 2000 Cerro Grande Fire have resulted in flow-regime changes with increased number, magnitude, and frequency of peak flows in the Capulin Creek and Rito de los Frijoles drainages. Aquatic biota shifts to disturbance-tolerant invertebrates and reduced taxa density were documented as a result of the postfire flash flooding associated with these large-scale wildfires, and postfire floods in the monument indicated elevated concentrations of selected cations, nutrients (nitrogen and phosphorus), and sediment.

The water-quality sites discussed in this report included 29 stream sites on Alamo Creek (67 samples), Capulin Creek (155 samples), and the Rito de los Frijoles (896 samples), and 4 springs (155 samples), including Apache, Basalt, Frijoles, and Turkey Springs. Most of the data for the evaluated surfacewater and spring sites were values of field properties and concentrations of major ions and nutrients. Various organic, pesticide, and (or) wastewater compounds were analyzed once or twice in samples from the Rito de los Frijoles and from Basalt Spring.

For the surface water in BAND, bacteriological contamination from back-country recreational use was identified as a water-quality concern in Alamo and Capulin Creeks and the Rito de los Frijoles. However, coliform sampling was infrequent, so it was not possible to identify whether the few exceedances identified (two each in Capulin Creek and the Rito de los Frijoles) were isolated occurrences of elevated coliform counts or whether exceedances were a regular occurrence associated with increased visitor numbers or other potential factors. Concerns regarding elevated levels of turbidity may be warranted; however, the cause of these elevated values is not clearly established, and natural runoff events may well be a factor in elevated turbidity, though recent (September 2001) sampling did not indicate elevated turbidity levels. The few trace-element data do not conform to State requirements for filtered fraction samples (for most constituents); therefore, determination of compliance with State standards was not possible. Censoring levels commonly matched or exceeded standard levels, which limited the ability to relate traceelement concentrations to regulatory criteria. Water-quality data were sparse for Apache, Basalt, Frijoles, and Turkey Springs in the monument and most of the available data were collected before 1979. The only spring with recent data is Basalt Spring. The volcanic tuff and (or) basalt underlying most of the monument are the principal drivers controlling the bicarbonate and calcium bicarbonate waters discharging from 
these springs. Elevated concentrations of nitrogen and phosphorus may be a consequence of local runoff, atmospheric deposition, trespass grazing near springs, or from transport through the aquifer from affected recharge areas outside the park. Elevated phosphorus concentrations at Basalt Spring also may be derived from apatite and related volcanic minerals associated with the underlying basalt.

Canyon de Chelly National Monument is in the high plateau area of the Navajo Nation Reservation in northeastern Arizona. The monument includes two main canyons (Canyon del Muerto and Canyon de Chelly) and two smaller canyons (Black Rock Canyon and Monument Canyon) along with multiple side canyons and arroyos. Tsaile Creek perennially feeds Canyon del Muerto, and Wheatfields and Whiskey Creeks (which are perennial in the upper reaches) are the principal streams flowing into Canyon de Chelly. Streams become intermittent or ephemeral in and near the monument. Navajos have used the Canyon de Chelly area for agriculture since A.D. 1700, which has contributed to the current state of range deterioration and poor condition of the riparian areas upstream from and within the monument. The 1996 Navajo Nation Watershed Prioritization Study ranked Canyon de Chelly watershed as the number one priority out of 18 locally identified watersheds for watershed restoration planning and project development.

Water-quality data from 225 samples were evaluated for this report and include data for water flowing into the monument from headwater creeks, including samples from Tsaile, Wheatfields, Whiskey, and Crystal Creeks and Monument Canyon (includes three sites within the park); samples from Tsaile and Wheatfields Lakes upstream from the monument; and samples from Chinle Wash flowing out of the park. Few water-quality data were collected prior to 1995 and few of the data were collected inside the monument boundary. Only four sites had more than 15 samples collected over the period of record. Monument Canyon has only one historical sample collected in 1978 and very little data (four samples) were collected for Chinle Wash, limiting potential interpretation of these waters. Data available from the headwater creeks and lakes in this park indicated reduced dissolved oxygen and elevated $\mathrm{pH}$ and turbidity levels, nutrients (unfiltered nitrogen and phosphorus), bacteriological counts (E. coli), suspended solids, and possibly elevated residual chlorine, though few data were available for this last constituent. Few data were available for Chinle Wash, which limited interpretation of changes in water quality occurring within the monument from natural sources or anthropogenic activities.

Chaco Culture National Historical Park is a semiarid desert steppe in the northwestern corner of New Mexico in the center of the San Juan River Basin on the southeastern part of the Colorado Plateau. The prominent geomorphic feature of the park is Chaco Canyon, which drains the valley from southeast to northwest and is characterized by a steep-walled canyon and gentle, sloping mesas. Chaco Wash becomes Chaco River near the park's northwest boundary and eventually flows into the San Juan River. The main canyon tributaries include Escavada, Fajada, and Gallo Washes and several smaller secondary washes and arroyos. Mining (coal and uranium) activities along with oil and gas exploration, coal-bed methane extraction, power generation, and associated water and residential development in the area surrounding the park are considered potential concerns for surface- and ground-water quantity and quality in this park. Erosion control is among the most critical resource needs of the park to protect its cultural resources.

Water-quality data from 797 surface-water samples were collected by the U.S. Geological Survey between January 1976 and October 1983. To evaluate water quality, the samples were divided into the following three stream groupings: Chaco Wash and Chaco River, which flow through the center of the park; three tributary washes to Chaco Canyon, including Escavada, Fajada, and Gallo Washes; and Kim-me-ni-oli Wash, which flows through the western part of the park. More than 90 percent of the samples were collected from Chaco Wash at Chaco National Monument. A large number (more than 500) of streamflow measurements, water-temperature measurements, and suspended sediment results were available from Chaco Wash; most other field properties and constituents were measured or analyzed much less frequently. Because these historical data (collected between 1976 and 1983) were the only water-quality data available for this area, these data were compared to current water-quality standards even though most of the current (2007) State water-quality standards were not applicable when these samples were collected.

Data from Chaco Wash generally indicated higher concentrations of nutrients and trace elements and more exceedances of New Mexico water-quality standards than were identified in the other evaluated waters in Chaco Culture National Historical Park. These elevated values may be a reflection of natural influences from the Lewis Shale and Menefee Formation, which are predominant in the Chaco Wash drainage area, or of the current land-use activities. Data from Chaco and Kim-me-ni-oli Wash indicated elevated gross alpha radioactivity, which could have resulted from weathering of radioactive minerals from source bedrock or from mining occurring in the contributing area. Concentrations of unfiltered nitrogen and phosphorus were elevated in analyses of samples from all waters evaluated in Chaco Culture National Historical Park and could be related to atmospheric deposition (nitrogen), bedrock weathering (primarily phosphorus), and upland and semiriparian zone grazing activities. Historical concentrations of trace elements were elevated for several constituents in one or more analyses of samples from park waters and exceeded State criteria for aquatic life for filtered aluminum, beryllium, copper, and zinc and for unfiltered mercury and selenium.

Glen Canyon National Recreation Area, which covers more than 1.2 million acres, extends from southeastern Utah more than $180 \mathrm{mi}$ into northeastern Arizona. The main feature of the park, Lake Powell, covers about 13 percent of the park area and terminates at Lees Ferry where the lake outflow becomes the Colorado River again. The remaining part of this park unit is a landscape of highly dissected red rock canyons, 
cliffs, and plateaus. The Colorado River is the main drainage into Lake Powell, and the Paria, Escalante, San Juan, and Dirty Devil Rivers are major tributaries that flow into Glen Canyon National Recreation Area. More than 90 side canyons fed by springs and ephemeral drainages are considered tributaries to the main body of Lake Powell.

Multiple water-resource concerns exist at Glen Canyon National Recreation Area, including grazing, off-road vehicle use, mineral and energy resource extraction and processing, development, and wildfires. Data from 117 surface-water samples collected between October 1947 and June 2003 were evaluated for this report in one of five stream groupings: three primary contributing perennial rivers (the Dirty Devil, Escalante, and Paria Rivers) and a composite of samples from a group of smaller tributaries that flow into the Escalante River or Lake Powell. Water data collected since 1988 from the Dirty Devil, Escalante, and Paria Rivers were assessed according to selected designated uses assigned by the State of Utah, including chronic aquatic-life cold and aquatic-life support exceedances and secondary-contact recreation standards. Additionally, applicable sections of the Paria River were assessed according to designated uses assigned by the State of Arizona, including chronic aquatic and wildlife warmwater exceedances and full-body contact standards. A second data and exceedance summary was compiled for the smaller intermittent or ephemeral tributaries flowing into the Escalante River or Lake Powell with one or more water-quality standard exceedance. These 14 waters, all within the Utah portion of Glen Canyon National Recreation Area, include five tributaries to the Escalante River (Coyote Gulch, East Moody Canyon, Harris Wash, Silver Falls Creek, and The Gulch) and nine tributaries to Lake Powell (Croton Canyon, Last Chance Creek, Little Valley Wash, North Wash, Tibbet Canyon, Trachyte Creek, Wahweap Creek, Wesses Canyon, and White Canyon Creek).

During the recent period of record (since 1988) for the Dirty Devil, Escalante, and Paria Rivers, frequent exceedances of water-quality standards or criteria by values of field properties and nutrient concentrations (greater than 25 percent) included low dissolved oxygen in the Arizona section of the Paria River, high turbidity in all three rivers, elevated unfiltered phosphorus in all three rivers, and elevated unfiltered nitrogen in the Escalante River. Water temperature measurements in the Escalante and Paria Rivers exceeded selected beneficial use criteria 19 and 15 percent of the time, respectively, during this time. Between one and 15 exceedances of dissolved oxygen, $\mathrm{pH}$, water temperature, or unfiltered phosphorus occurred since 1988 in one or more of the evaluated tributaries. During the recent period of record for the three rivers, filtered trace elements with five or more exceedances included aluminum, beryllium, iron, and manganese in the Paria River, and barium in the Escalante and Paria Rivers. Historical and recent data for filtered selenium in the Paria River indicated elevated concentrations. Since 1988, one to eight filtered trace element concentrations exceeded their standard in analyses of samples collected from 12 of the 14 evaluated tributaries. Natural geologic processes and multiple anthropogenic factors may contribute to elevated concentrations of selected constituents in park waters. Erosion can result in high levels of solids and sediment that can lead to elevated turbidity, which can in turn result in increased water temperatures, increased concentrations of phosphorus and selected trace elements, and reduced dissolved oxygen concentrations.

Mesa Verde National Park is in southwestern Colorado and encompasses much of a prominent mesa with a steep, highly eroded escarpment at the northern end of the park. Multiple north-south-trending, gently sloping, flat-topped ridges separated by rugged canyons drop from the escarpment to the Mancos River to form numerous ephemeral drainages. The Mancos River is a perennial stream that originates in the La Plata Mountains north of Mancos, Colorado, and flows for $4.7 \mathrm{mi}$ along the eastern park boundary. Numerous springs are found throughout the park, discharging primarily from the exposed sandstone and shale formations of the Mesaverde Group. These springs, although typically very small, compose the critical water resources available to wildlife.

Water-quality issues for the Mancos River, as identified in the Inventory and Monitoring Phase II Report, include nutrient and bacterial contamination from trespass grazing in the Mancos River riparian corridor and from sewage-treatment facilities within and upstream from the park. Insecticide and algicide applications in and surrounding the park and runoff of silt from neighboring gravel pits, streets, unpaved roads, and development along the Mancos River corridor upstream from the park are also concerns. Metals contamination from mining and ore processing in areas adjacent to and upstream from the park and potential contamination from natural-gas lines crossing the Mancos River upstream from the park are additional concerns. Fire (the most recent occurred in 2000) and drought have been important factors in and surrounding the park. Water-quality issues for the park's springs, as identified during Phase II of the Inventory and Monitoring Program, include atmospheric pollutant deposition from coalfired powerplants and oil and gas development in the Four Corners area; erosion and water-quality effects from large episodic forest fires; and discharge from sewage lagoons in Soda, Morefield, and Navajo Canyons. This report focused on selected sites on the Mancos River in the vicinity of the park and selected springs inside the park. The frequency of waterquality sample collection along the Mancos River has varied with few sites offering more than a historical snapshot of water-quality conditions with only three sites having 5 or more years of record since 1971 (only two sites have been sampled since 2000).

Water-quality data for springs were collected by the National Park Service at 36 sites in Mesa Verde National Park; one-half of the samples were collected from four springs. The Mancos River increases in dissolved ions, particularly calcium and sulfate, as it flows from the town of Mancos, along the park boundary, and downstream from the park toward Johnson Canyon, indicating an increasing effect of 
drainage from Mancos Shale and Menefee Formation terrains. Concentrations of aluminum, selenium, and zinc exceeded the State standards one or more times at the sites in or just upstream from the park. These elevated concentrations could be related to upstream geology or to anthropogenic activities such as agricultural or mining activities. The quality of the water discharging from springs in Mesa Verde National Park appears to be controlled primarily by the surrounding geologic formations, resulting in elevated concentrations of nutrients, major ions, and selected trace elements. Concentrations of aluminum, cadmium, chromium, copper, iron, lead, nickel, selenium, and zinc each exceeded their respective waterquality standard one or more times. Aluminum concentrations were particularly high in samples from two springs and may warrant a focused study to evaluate the source. Elevated concentrations of nitrogen and phosphorus could be related to surrounding geology (phosphorus), to fire effects, or to activities within or upgradient from the park, including the sewage lagoons in the park.

\section{References Cited}

Allen, Craig, Hanson, B., and Mullins, C., eds., 1993, Cochiti Lake reregulation interagency biological report, June 30, 1993: Los Alamos, New Mexico, Bandelier National Monument, $64 \mathrm{p}$.

Anderson, P.B., Chidsey, T.C., Jr., Sprinkel, D.A., and Willis, G.C., 2003, Geology of Glen Canyon National Recreation Area, Utah-Arizona, in Sprinkel, D.A., Chidsey, T.C., Jr., and Anderson, P.B., 2003, Geology of Utah's parks and monuments: Utah Geological Association Publication 28 (2d ed.), p. 301-336.

Arizona Department of Environmental Quality, 2005, Arizona's total maximum daily load program-History and current status as of 12/19/05, accessed September 1, 2006, at URL http://www.azdeq.gov/environ/water/assessment/ status.html

Arthur, Dan, Langhus, B., and Rawn-Schatzinger, V., 2003, Coalbed natural gas resources and produced water management: Houston, Texas, Hart Energy Publishing, LP, GasTIPS v. 9, no. 3, p. 20-24.

Baars, D.L., 2000, The Colorado Plateau-A geologic history: Albuquerque, University of New Mexico Press, 254 p.
Barrows, Kathleen, 2003, A breath of fresh air-How smarter energy choices can protect the health of New Mexicans: Physicians for Social Responsibility, accessed September 2005, at URL at www.psr.org

Bills, D.J., Flynn, M.E., and Monroe, S.A., 2007, Hydrogeology of the Coconino Plateau and adjacent areas, Coconino and Yavapai Counties, Arizona: U.S. Geological Survey Scientific Investigations Report 2005-5222, 99 p., 4 plates.

Bureau of Indian Affairs, 2007, Desert Rock Energy Project: Draft Environmental Impact Statement: U.S. Department of Interior, Bureau of Indian Affairs, Navajo Regional Office, Gallup, New Mexico, DOI DES 07-23, accessed August 1, 2008, at URL http://www.desertrockenergy.com/

Carroll, C.J., Kirkham, R.M., and Wilson, S.C., 1998, Geologic map of the Ludwig Mountain quadrangle, La Plata County, Colorado-Description of map units, economic geology, fracture data, and references: U.S. Geological Survey Open-File Report 98-2, 13 p., accessed May 25, 2005, at URL geosurvey.state.co.us/pubs/gis_data/mapping/ LudMtn_units.pdf

Carter, L.F., 1997, Water-quality assessment of the Rio Grand Valley, Colorado, New Mexico, and Texas-Organic compounds and trace elements in bed sediment and fish tissue, 1992-1993: U.S. Geological Survey Water-Resources Investigations Report 97-4002, 23 p.

Chapman, Deborah, ed., 1998, Water quality assessments-A guide to the use of biota, sediments and water in environmental monitoring ( $2 \mathrm{~d}$ ed.): New York, E \& FN Spon, $626 \mathrm{p}$.

Christensen, P.K., 1980, Base flow sources in the upper reaches of Rito de Los Frijoles, Bandelier National Monument: National Park Service, Water Resources Report no. $80-5,17$ p.

Colorado Department of Public Health and Environment, 2002a, Regulation no. 34 classification and numeric standards for San Juan River and Dolores River basins, accessed March 3, 2005, at URL www.cdphe.state.co.us/ regulations/wqccregs/34_0207ts.pdf

Colorado Department of Public Health and Environment, 2002 b, Status of water quality in Colorado, accessed May 25, 2005, at URL http://www.cdphe.state.co.us/op/wqcc/ waterstatus_305_b/waterstatus2002/305(b)tableofcontents. html 
Colorado Department of Public Health and Environment, 2004, Regulation no. 932004 section 303(d) list waterquality-limited segments requiring TMDLs, accessed November 11, 2004, at URL www.cdphe.state.co.us/ regulations/wqccregs/100293wqlimitedsegtmdls.pdf

Colorado Department of Public Health and Environment, Water Quality Control Commission, 2005, Regulation no. 31 , the basic standards and methodologies for surface water, 5 CCR 1002-31, accessed January 22, 2007, at URL http://www.cdphe.state.co.us/regulations/wqccregs/100231b asicstandards1205and1207.pdf

Durum, W.H., and Haffty, J.H., 1961, Occurrence of minor elements in water: U.S. Geological Survey Circular 445, $11 \mathrm{p}$.

Eckert, Gregory, Greco D., Wagner, J., Martin, M., Benjamin, P., Deuser, C., Hansen, M., and Rees, M., 2003, October 2003 natural resources assessment trip report (Memorandum): Fort Collins, Colorado, National Park Service, Natural Resource Program Center, 19 p.

Eychaner, J.H., 1983, Geohydrology and effects of water use in the Black Mesa Area, Navajo and Hopi Indian Reservations, Arizona: U.S. Geological Survey Water-Supply Paper 2201, 26 p.

Floyd, M.L., Romme, W.H., and Hanna, D.D., 2000, Fire history and vegetation pattern in Mesa Verde National Park, Colorado, USA: Ecological Applications, v. 10, no. 6, p. 1666-1680.

Floyd, M.L., and Salamacha, G., 2001, Post-fire treatment of noxious weeds in Mesa Verde National Park, Colorado, in van Riper III, C., Thomas, K.A., and Stuart, M.A., eds., 2001, Proceedings of the fifth biennial conference of research on the Colorado Plateau: U.S. Geological Survey Forest and Rangeland Ecosystem Science Center Report Series USGSFRESC/COPL/2001/24, p. 1666-1680.

Galloway, J.N., Aber, J.D., Erisman, J.W., Seitzinger, S.P., Howarth, R.W., Cowling, E.B., and Cosby, B.J., 2003, The nitrogen cascade: Bioscience, v. 53, no. 4, p. 341-356.

Gardner, L.R., 1990, The role of rock weathering in the phosphorus budget of terrestrial watersheds: Biogeochemistry, v. 11, no. 2, p. 97-110.

Gaug, Maryann, 2001, After the fires-Mesa Verde National Park: Cyberwest Magazine, no. 20, September 5, 2001, accessed April 21, 2005, at URL http://www.cyberwest.com/ cw20/mesa_verde_fires.html

Gellis, A.C., 2002, Twentieth century arroyo changes in Chaco Culture National Historical Park: U.S. Geological Survey Water-Resources Investigations Report 2001-4251, 42 p.
Goetz, C.L., Abeyta, C.G., and Thomas, E.V., 1987, Application of techniques to identify coal-mine and power-generation effects on surface-water quality, San Juan River Basin, New Mexico and Colorado: U.S. Geological Survey WaterResources Investigations Report 86-4076, 80 p.

Gray, J.R., Glysson, G.D., Turcios, L.M., and Schwarz, G.E., 2000, Comparability of suspended-sediment concentration and total suspended solids data: U.S. Geological Survey Water-Resources Investigations Report 2000-4191, 15 p.

Griffitts, M.O., 1990, Guide to the geology of Mesa Verde National Park: Utah, Lorraine Press, 88 p.

Haines, Leslie, ed., 2003, Coalbed methane-A supplement to oil and gas investor: Chemical Week Associates, Houston, Texas, Hart Publications, accessed May 25, 2005, at URL www.oilandgasinvestor.com/pdf/Coalbed_Methane.pdf

Harshbarger, J.W., and Repenning, C.A., 1954, Water resources of the Chuska Mountains area, Navajo Indian Reservation, Arizona and New Mexico: U.S. Geological Survey Circular 308, 16 p.

Hart, R.J., Ward, J.J., Bills, D.J., and Flynn, M.E., 2002, Generalized hydrogeology and ground-water budget for the C Aquifer, Little Colorado River Basin and parts of the Verde and Salt River Basins, Arizona and New Mexico: U.S. Geological Survey Water-Resources Investigations Report 2002-4026, 45 p.

Hart, R.J., Taylor, H.E., Antweiler, R.C., Fisk, G.G., Anderson, G.M., Roth, D.A., Flynn, M.E., Peart, D.B., Truin, M., and Barber, L.A., 2005a, Physical and chemical characteristics of Knowles, Forgotten, and Moqui Canyons and effects of recreational use on water quality, Lake Powell, Arizona and Utah: U.S. Geological Survey Scientific Investigations Report 2004-5120, 43 p.

Hart, R.J., Taylor, H.E., Antweiler, R.C., Graham, D.D., Fisk, G.G., Riggins, S.G., and Flynn, M.E., 2005b, Sediment chemistry of the Colorado River delta of Lake Powell, Utah, 2001: U.S. Geological Survey Open-File Report 2005-1178, $33 \mathrm{p}$.

Hejl, H.R., Jr., 1982, Hydrologic investigations and data-collection network in strippable coal areas in northwestern New Mexico: U.S. Geological Survey Open-File Report 82-358, $32 \mathrm{p}$.

Helsel, D.R., and Cohn, T.A., 1988, Estimation of descriptive statistics for multiply censored water quality data: Water Resources Research, v. 24, no. 12, p. 1997-2004.

Hem, J.D., 1989, Study and interpretation of the chemical characteristics of natural water ( $3 \mathrm{~d}$ ed.): U.S. Geological Survey Water-Supply Paper 2254, 263 p. 
Holloway, J.M., and Dahlgren, R.A., 2002, Nitrogen in rock-Occurrence and biogeochemical implications: Global Biogeochemical Cycles, v. 16, no. 4, p. 65-1-65-17.

Insightful Corporation, 2007, S-PLUS 6.1 for Windows support page, accessed January 13, 2007, at URL http://www. insightful.com/support/splus61win/

Jagoe, C.H., Matey, V.E., Haines, T.A., and Komov, V.T., 1993, Effect of beryllium on fish in acid waters is analogous to aluminum toxicity: Aquatic Toxicology, v. 24, p. 241-256.

Jeffries, D.S., Wales, D.L., Kels, J.R.M., and Linthurst, R.A., 1986, Regional characteristics of lakes in North AmericaPart I, Eastern Canada: Water, Air, Soil Pollution, v. 31, p. 555-567.

Macy, J.P., and Monroe, S.A., 2006, Water-quality data for selected National Park units within the southern Colorado Plateau network, Arizona, Utah, Colorado, and New Mexico, water years 2005 and 2006: U.S. Geological Survey Open-File Report 2006-1300, 84 p.

Martin, Larry, 2005, A general description of the hydrogeology, water supply wells, groundwater monitoring, and potential threats to groundwater resources of Chaco Culture National Historical Park, New Mexico: Fort Collins, Colorado, National Park Service, Water Resources Division, Technical Report NPS/NRWRD/NRTR-2005/325, 35 p.

McCalpin, J.P., 2005, Late Quaternary activity of the Pajarito fault, Rio Grande rift of northern New Mexico, USA: Tectonophysics, v. 408, no. 1-4, p. 213-236, accessed August 15, 2008, at URL http://www.sciencedirect.com/ (doi:10.1016/j.tecto.2005.05.038)

McGarigle, Bill, 1998, Elk collared in New Mexico: Government Technology Magazine, January 1, 1998, accessed January 23, 2007, at URL http://www.govtech.net/ magazine/story.print.php? id $=94912$

Microbac Laboratories, Inc., 2005, An Overview of Mercury and Methods for Its Analysis, accessed August 1, 2008, at URL http://microbac.com/uploads/200507071106240. Mercury\%20--\%202005.pdf

Millennium Science \& Engineering, Inc., 2005, Escalante River Watershed water quality management plan-Draft, February 3, 2005. 47 p.

Mott, David, 1999, Water resources management plan, Bandelier National Monument, New Mexico: National Park Service, Bandelier National Monument, 145 p.
Mueller, D.K., Hamilton, P.A., Helsel, D.R., Hitt, K.J., and Ruddy, B.C., 1995, Nutrients in ground water and surface water of the United States-An analysis of data through 1992: U.S. Geological Survey Water-Resources Investigations Report 95-4031, p. 7.

National Park Service, [n.d. a], Chaco Culture National Historical Park. The center of Chacoan culture, accessed March 14, 2006, at URL http://www.nps.gov/chcu/chacoan. htm

National Park Service, [n.d. b], Chaco Culture National Historical Park, New Mexico, accessed March 14, 2006, at URL http://www.cr.nps.gov/worldheritage/chaco.htm

National Park Service, 1997, Baseline water quality data inventory and analysis, Bandelier National Monument: National Park Service, Water Resources Division, Fort Collins, Colorado, Technical Report NPS/NRWRD/ NRTR-97/103, 717 p., accessed April 13, 2007, at URL http://www1.nature.nps.gov/water/horizon.cfm

National Park Service, 2004, Chaco Culture National Historical Park_Geology, accessed March 13, 2006, at URL http://www.nps.gov/chcu/geology.htm

National Park Service, 2005a, Cooperative watershed restoration project-Tamarisk and russian olive management at Canyon de Chelly National Monument, Draft Environmental Assessment: U.S. Department of the Interior, National Park Service, Canyon de Chelly National Monument, Arizona, 181 p.

National Park Service, 2005b, Park vital signs monitoringTaking the pulse of the national parks: Fort Collins, Colorado, U.S. Department of the Interior, National Park Service, Natural Resource Program Center, Office of Inventory, Monitoring and Evaluation, $4 \mathrm{p}$.

National Park Service, 2006, Glen Canyon National Recreation Area-Laws and policies: National Park Service, accessed August 31, 2006, at URL http://www.nps.gov/glca/ parkmgmt/lawsandpolicies.htm

National Park Service, Land Resources Division, 2006, National Park Service listing of acreage as of 12/31/2006: National Park Service, Public Use Statistics Office, accessed January 23, 2007, at URL http://www2.nature.nps. gov/stats/

National Park Service, Public Use Statistics Office, 2006, Park by year 1904-2005: National Park Service, Public Use Statistics Office, accessed January 23, 2007, at URL http:// www2.nature.nps.gov/stats/ 
Nations, Dale, and Stump, E., 1981, Geology of Arizona: Dubuque, Iowa, Kendall / Hunt Publishing Company, 221 p.

Natural Resources Conservation Service, 1999, 2d draft natural resource plan for Canyon del Muerto/Tsaile Creek Watershed, Apache County, Arizona and San Juan County, New Mexico: U.S. Department of Agriculture, Natural Resources Conservation Service, Water Resources Planning, 43 p. plus appendixes.

Paerl, H.W., 1997, Coastal eutrophication and harmful algal blooms-Importance of atmospheric deposition and groundwater as "new" nitrogen and other nutrient sources: Limnology and Oceanography, v. 42, no. 5, p. 1154-1165.

Pesticide Action Network North America, 2002, Pesticide action network pesticide database, water quality standards, criteria and guidelines: Pesticide Action Network North America, accessed February 2, 2006, at URL http://www. pesticideinfo.org/Docs/ref_waterair2.html\#RfD

Purtymun, W.D., and Adams, H., 1980, Geohydrology of Bandelier National Monument, New Mexico: Los Alamos, New Mexico, Los Alamos Science Laboratory, 25 p.

Rawn-Schatzinger, Viola, Arthur, Dan, and Langhus, B., 2004, Coalbed natural gas resources-Beneficial use alternatives: Houston, Texas, Hart Energy Publishing, LP, GasTIPS, v. 10 , no. 1 , p. $9-14$.

Robson, S.G., and Banta, E.R., 1995, Ground water atlas of the United States, segment 2, Arizona, Colorado, New Mexico, Utah: U.S. Geological Survey Hydrologic Investigations Atlas 730-C, p. C7.

Rothman, Hal, 1988, Bandelier National Monument-An administrative history: National Park Service Professional Papers no. 14, Santa Fe, New Mexico, Southwest Cultural Resources Center, Division of History, accessed June 16, 2005, at URL http://www.nps.gov/band/adhi/adhi.htm

San Juan Citizens Alliance, 2002, San Juan Citizens Alliance 2002 annual report-Responsible oil and gas development: Durango, Colorado, accessed August 8, 2007, at http://www. sanjuancitizens.org/otherpages/publications.shtml

Scott, G.R., O’Sullivan, R.B., and Weide, D.L., 1984, Geologic map of the Chaco Culture National Historical Park, northwestern New Mexico: U.S. Geological Survey Miscellaneous Investigations Series Map, I-1571, 1 sheet, scale 1:50,000.
Scurlock, Dan, 1998, From the Rio to the Sierra-An environmental history of the middle Rio Grande Basin: U.S. Department of Agriculture, Rocky Mountain Research Station, General Technical Report RMRS-GTR-5, 454 p.

Sposito, Garrison, ed., 1996, The environmental chemistry of aluminum ( $2 \mathrm{~d}$ ed.): Boca Raton, Florida, CRC Press, Inc., $464 \mathrm{p}$.

State of Arizona, 2002, Arizona administrative code, title 18. Environmental quality, chapter 11: Department of Environmental Quality Water Quality Standards, accessed December 31, 2002, at URL http://www.azsos.gov/public_ services/Title_18/18-11.htm

State of New Mexico, 2002, Standards for interstate and intrastate surface waters 20.6.4 NMAC, accessed November 14, 2003, at URL http://www.nmenv.state.nm.us/NMED_ regs/swqb/20_6_4_nmac.html

State of New Mexico, 2004, 2004-2006 State of New Mexico integrated Clean Water Act $\$ 303(\mathrm{~d}) / \S 305$ (b) report, accessed June 22, 2005, at URL http://www.nmenv.state. nm.us/wqcc/303d-305b/2004/AppendixB/index.html

Suter, G.W. II, and Tsao, C.L., 1996, Toxicological benchmarks for screening potential contaminants of concern for effects on aquatic biota-1996 revision: Oak Ridge, Tennessee, Lockheed Martin Energy Systems, Inc., Risk Assessment Program, Health Sciences Research Division, ES/ER/TM-96/R2, $151 \mathrm{p}$.

Thomas, L.P., Hendrie, M.N., editor, Lauver, C.L., Monroe, S.A., Tancreto, N.J., Garman, S.L., and Miller, M.E., 2006, Vital signs monitoring plan for the Southern Colorado Plateau Network: Natural Resources Report NPS/SCPN/ NRR-2006/002, National Park Service, Fort Collins, Colorado, accessed April 9, 2007, at URL http://science. nature.nps.gov/im/monitor/MonitoringPlans.cfm

Thomas, L.P., Lauver, C.L., Hendrie, M.N., Tancreto, N.J., Whittier, J., Atkins, J., Miller, M.E., and Cully, A., 2004, Vital signs monitoring plan for the Southern Colorado Plateau Network-Phase II Report: Flagstaff, Arizona, National Park Service, Southern Colorado Plateau Network, 163 p. plus appendixes.

Thomas, L.P., Whittier, J., Tancreto, N.J., Atkins, J., Miller, M.E., and Cully, A., 2003, Vital signs monitoring plan for the Southern Colorado Plateau Network-Phase I Report: Flagstaff, Arizona, National Park Service, Southern Colorado Plateau Network, 89 p. plus appendixes. 
U.S. Congress, 1960, Public Law 86-645, 74 Statute 480: U.S. Congress, 86th, 24 p.

U.S. Congress, 1964, Public Law 88-293, 78 Statute 171: U.S. Congress, 88th, 2d session, $615 \mathrm{p}$.

U.S. Environmental Protection Agency, 2001, Frequently asked questions about atmospheric deposition-A handbook for watershed managers: Washington, D.C., U.S. Environmental Protection Agency Office of Wetlands, Oceans, and Watersheds, EPA-453/R-01-009, accessed March 30, 2006, at URL http://www.epa.gov/owow/ airdeposition/

U.S. Environmental Protection Agency, 2002, Ecoregional criteria, accessed November 10, 2008, at URL http://www. epa.gov/waterscience/criteria/nutrient/ecoregions/

U.S. Environmental Protection Agency, 2005, Water quality standards database, accessed May 23, 2005, at URL http:// www.epa.gov/wqsdatabasel

U.S. Environmental Protection Agency, 2006a, Overview of current total maximum daily load-TMDL_program and regulations: U.S. Environmental Protection Agency Office of Wetlands, Oceans and Watersheds, accessed January 23, 2007, at URL http://www.epa.gov/owow/tmdl/overviewfs. html

U.S. Environmental Protection Agency, 2006b, Technical factsheet on: di (2-ethylhexyl) phthalate (DEHP): U.S. Environmental Protection Agency Office of Ground Water and Drinking Water, accessed February 2, 2006, at URL http://www.epa.gov/safewater/dwh/t-soc/dehp.html

U.S. Environmental Protection Agency, 2006c, Current national recommended water quality criteria: U.S. Environmental Protection Agency Office of Water, accessed January 23, 2007, at URL http://www.epa.gov/waterscience/criteria/ wqcriteria.html

U.S. Environmental Protection Agency Office of Water, 1985, Ambient water quality criteria for chlorine-1984: U.S. Environmental Protection Agency Office of Water EPA 440/5-84-030, 57 p.

U.S. Environmental Protection Agency Office of Water, 1999, Combined sewer overflow technology fact sheet-Chlorine disinfection: U.S. Environmental Protection Agency Office of Water Fact Sheet EPA 832-F-99-034, 10 p.

U.S. Geological Survey, 1991, Contamination of dissolved trace-element data-Present understanding, ramifications, and issues that require resolution: Office of Water Quality Technical Memorandum 91.10, accessed April 23, 2007, at URL http://water.usgs.gov/admin/memo/QW/qw91.10.html
U.S. Geological Survey, 2001, National Water Information System (NWISWeb) data available on the World Wide Web, accessed August 31, 2006, at URL http://www.water.usgs. gov/.

U.S. Geological Survey, 2006, User's manual for the National Water Information System of the U.S. Geological SurveyWater-quality system: U.S. Geological Survey Open-File Report Version 4.6, accessed January 23, 2007, at URL http://wwwnwis.er.usgs.gov/nwisdocs4_6/qw/QW.user.book. html

Utah Department of Environmental Quality, 2005, Standards of quality for waters of the state, R317-2, Utah Administrative Code, accessed January 22, 2007, at URL http://www.rules.utah.gov/publicat/code/r317/r317-002. htm\#E15

Utah State University, 2004, 1:500,000 scale geology for the southwestern U.S. (version 1.0): RS/GIS Laboratory, College of Natural Resoources, Utah State University, accessed May 18, 2005, at URL http://ftp.nr.usu.edu/swgap/ geology.html

Veenhuis, J.E, 2002, Effects of wildfire on the hydrology of Capulin and Rito de Los Frijoles Canyons, Bandelier National Monument, New Mexico: U.S. Geological Survey Water-Resources Investigations Report 2002-4152, 44 p.

Vieira, N.K., Clements, W.H., Guevara, L.S., and Jacobs, B.F., 2004, Resistence and resilience of stream insect communities to repeated hydrologic disturbances after a wildfire: Freshwater Biology, v. 49, p. 1243-1259.

Western Regional Climate Center, 2006, Western U.S. climate historical summaries, accessed April 25, 2007, at http:// www.wrcc.dri.edu/climsum.html

Wilberg, D.E., and Stolp, B.J., 2005, Seepage investigation and selected hydrologic data for the Escalante River drainage basin, Garfield and Kane Counties, Utah, 1909-2002: U.S. Geological Survey Scientific Investigations Report 2004-5233, 39 p.

Williams, M.W., and Tonnessen, K.A., 2000, Critical loads for inorganic nitrogen deposition in the Colorado Front Range, USA: Ecological Applications, v. 10, no. 6, p. 1648-1665.

Wing, K.A., 1957, Bandelier National Monument, New Mexico: National Park Service Historical Handbook Series no. 23, accessed June 16, 2005, at http://www.cr.nps.gov/ history/online_books/hh/23/index.htm 


\section{Appendix. Overview of Water-Quality Properties of Interest to Southern Colorado Plateau Network Park Units}

\begin{abstract}
National Park Service (NPS) natural resource managers without a background in water-quality analysis may find some background information on the water-quality properties discussed within this report helpful. An overview of the relevance of particular field measurements or constituent values is provided herein along with definitions of selected properties. Known aquatic effects and interrelations between properties and constituents also are described, where applicable.
\end{abstract}

\section{Field Properties}

Commonly measured field properties used for assessing water quality include dissolved oxygen concentrations, $\mathrm{pH}$, specific conductance, and water temperature; these, along with streamflow, are the four core field properties required by the NPS for the water-quality monitoring component of the Vital Signs Program (Freshwater Workgroup Subcommittee, 2002). Additional useful field properties for evaluating water quality include acid neutralizing capacity and turbidity.

Dissolved oxygen (DO) concentrations vary with water temperature, salinity, turbidity, photosynthetic activity of algae and plants, and atmospheric pressure, with oxygen solubility decreasing as temperatures and salinity increase. Dissolved oxygen concentrations can vary seasonally and diurnally (that is, over a 24-hour period) relative to biological photosynthetic and respiratory activities and water temperature. Because oxygen is involved in or influences nearly all chemical and biological processes in water, it is a fundamental part of waterquality assessment. One-day average standards for DO vary among States for SCPN park areas and range from $6.0 \mathrm{mg} / \mathrm{L}$ to $7.0 \mathrm{mg} / \mathrm{L}$ for cold-water fisheries and from $5.0 \mathrm{mg} / \mathrm{L}$ to $6.0 \mathrm{mg} / \mathrm{L}$ for warm-water fisheries, depending on the life stage of the fishery being evaluated (table 2). Chronically low DO values can result in stressed or reduced fish and macroinvertebrate populations (Chapman, 1998; Giller and Malmqvist, 1998).

$\mathrm{pH}$ is an important variable in water quality because it influences many chemical reactions and biological processes within a water body. The $\mathrm{pH}$ indicates the acidic or basic character of a water body at a given temperature and varies as a function of temperature (Chapman, 1998). The chronic cold and warm aquatic-life and recreation $\mathrm{pH}$ standards for Arizona, Colorado, New Mexico, and Utah range between 6.5 and 6.6 standard units (SU) for the minimum standard and between 8.8 and 9.0 SU for the maximum standard (table 2). High $\mathrm{pH}$ levels (greater than 9.0 SU) can harm fish by denaturing cellular membranes, resulting in reduced biological activity Murphy, 2005). Eutrophic (nutrient-enriched) waters can elevate $\mathrm{pH}$ and reduce carbon dioxide. Fish also are strongly affected by low $\mathrm{pH}$, especially in waters with elevated concentrations of aluminum (Giller and Malmqvist, 1998).

Specific conductance (SC) is the measure of the capacity of water to conduct an electric current and is proportional to the relative concentrations of dissolved solids and major ions (Chapman, 1998). Specific conductivity values reflect the concentration of major dissolved ions (for example, common anions - bicarbonate, chloride, and sulfate; common cationssodium, magnesium, calcium, and potassium) and can influence aquatic biota sensitive to high salinity levels or high concentrations of selected ions. No water-quality standards exist for specific conductance in the SCPN area, except in New Mexico, where low $(300 \mu \mathrm{S} / \mathrm{cm})$ and high standards $(1,500 \mu \mathrm{S} / \mathrm{cm})$ have been established for high-quality coldwater fisheries. Specific conductance is influenced by flow and generally decreases with increasing streamflow.

As with DO, water temperatures vary seasonally and diurnally. Altitude, latitude, season, time of day, air circulation, cloud cover, flow, and depth of water all influence water temperature, and temperature affects physical, chemical, and biological processes in the water column (Chapman, 1998). Instantaneous water temperature standards for coldand warm-water fisheries range from 20 to $25^{\circ} \mathrm{C}$ and 27 to $32.2^{\circ} \mathrm{C}$, respectively, depending on the fishery classification and State regulations (table 2). Water temperature influences biota by affecting metabolic rates and oxygen concentrations in the water, while most life history aspects of insects are affected by water temperature (Giller and Malmqvist, 1998). The rate of chemical reactions and biological functions (for example, aquatic organism metabolic rate) increase with increasing water temperatures, which can in turn increase oxygen consumption, the decomposition of organic matter, and the solubility of some constituents and all gases in water (Chapman, 1998).

Acid neutralizing capacity (ANC) is a measure of the ability of water to resist or neutralize changes in $\mathrm{pH}$ (buffering capacity) and has been more specifically defined as the difference between the sum of base cations $(\mathrm{Ca}+\mathrm{Mg}+\mathrm{Na}+\mathrm{K})$ and strong acid anions $\left(\mathrm{SO}_{4}+\mathrm{NO}_{3}+\mathrm{Cl}\right)$. The closely related term alkalinity refers to filtered samples (dissolved into solution), whereas ANC refers to unfiltered samples that include the dissolve solutes plus the solid and suspended materials (Rounds, July 2006). An "ANC sensitivity scale" for defining the relative buffering capacity of lakes was developed by Jeffries and others (1986). The condition of a lake or stream improves as the ANC levels increase. ANC levels at or below zero are considered "chronically acidic" indicating acidic conditions where the water has lost its capacity to buffer acidity; streams with ANC levels below 25 microequivalents per liter are considered "transiently acidic" indicating variably acidic conditions where the water may retain some limited ability to buffer acidity (Lazorchak and others, 2000).

Turbidity is a physical characteristic of water. It can be defined as "an expression of the optical property that causes light to be scattered and absorbed by particles and molecules rather than transmitted in straight lines through a water 
sample" (U.S. Environmental Protection Agency, 1999, p. 7-1). Turbidity can vary seasonally due to changes in biological activity in the water and the amount of surface runoff. Heavy rainfall events can result in short-term large increases in turbidity. Normal turbidity values range from 1 to 1,000 nephelometric turbidity units (NTU), but measurements can be affected by instrument type and calibration, storage of samples prior to measurement, settling (during storage), and changes in $\mathrm{pH}$. Natural or anthropogenic organic matter such as sewage effluent or high suspended-sediment concentrations can lead to increased levels of turbidity (Chapman, 1998).

High turbidity levels may be harmful to fish and their larvae because sunlight increases the water temperatures resulting in reduced DO concentrations. Additionally, photosynthesis can be reduced because of limiting light to aquatic plants (Giller and Malmqvist, 1998).

\section{Major Ions}

Commonly evaluated major ions include bicarbonate, calcium, chloride, fluoride, magnesium, potassium, silica, sodium, and sulfate. These selected cations and anions are commonly dissolved in most natural water as a result of surface- and ground-water interactions, geology, soil, aquifer composition, and human activities. Collectively, major ions are used to characterize water types (for example, calcium carbonate water) of various water bodies using techniques such as mathematical ratios, ion-concentration diagrams, and trilinear (Piper) diagrams (Hem, 1989).

\section{Nutrients}

Nutrients (ammonia, nitrate, nitrite, total nitrogen, orthophosphate, and phosphorus) in water can originate from various sources, including natural sources (erosion of rocks and soil containing phosphorus minerals, organic matter decomposition, and atmospheric deposition) and anthropogenic sources (fossil fuel combustion, fertilizers, phosphate detergents, and discharges from sewage-treatment facilities, septic systems, and animal feedlots).

Ammonia in water can result from multiple sources, including the breakdown of nitrogenous organic and inorganic materials in water and soil, human and animal wastes, atmospheric gas exchange, selected industrial processes, and the reduction of nitrogen gas in water by microorganisms (Chapman, 1998). At certain pH levels, elevated concentrations of [un-ionized] ammonia $\left(\mathrm{NH}_{3}\right)$ are toxic to aquatic life. State water-quality standards for un-ionized ammonia are computed as site-specific table-value standard dependent on temperature and $\mathrm{pH}$ (table 2). High concentrations of ammonia in water (for example, 2 to $3 \mathrm{mg} / \mathrm{L}$ or higher) are a useful indicator of organic pollution from sources such as domestic sewage, fertilizer runoff, or industrial waste (Chapman, 1998). Unfiltered ammonia is the sum of un-ionized ammonia and the concentration of the ammonium ion $\left(\mathrm{NH}_{4}^{+}\right)$in water.

Nitrate $\left(\mathrm{NO}_{3}^{-}\right)$and nitrite $\left(\mathrm{NO}_{2}^{-}\right)$are present in natural waters. Nitrate is the common form of nitrogen in water, but it can be biochemically reduced to nitrite through denitrification. Typically, nitrite is rapidly oxidized to nitrate and generally is not detected or is detected only in very small concentrations in surface water. While nitrate and nitrite can occur in ground water from soil leaching, elevated concentrations of these constituents in ground water are typically an indication of anthropogenic effects. Industrial and municipal wastes and inorganic nitrogen fertilizers can contribute to elevated nitrate concentrations. Weathering of igneous rocks, plant and animal decomposition, and runoff are additional natural sources of nitrate to surface waters (Chapman, 1998). Total nitrogen (unfiltered or filtered) includes concentrations of nitrate, nitrite, ammonia, and organic nitrogen. There are currently (2007) no waterquality standards for total nitrogen in Arizona, Colorado, New Mexico, or Utah; therefore, total nitrogen values from surfacewater samples collected in all four States were evaluated using the USEPA-recommended ecoregional nutrient criteria for rivers and streams (U.S. Environmental Protection Agency, 2002).

Phosphorus, which occurs in water in dissolved and particulate form, is an essential nutrient for living organisms and is generally the limiting nutrient for algal growth and primary productivity in a water body (Chapman, 1998). Natural sources of phosphorus include the weathering of phosphorusrich rocks and decomposed organic matter. Anthropogenic sources of phosphorus include wastewater (primarily from detergents), fertilizer runoff, and industrial effluent. There are currently (2007) no water-quality standards for phosphorus in Arizona, Colorado, or New Mexico; the USEPA ecoregional nutrient criteria for rivers and streams were used to evaluate the filtered or unfiltered total phosphorus data from the waters in these three States (U.S. Environmental Protection Agency, 2002). Total phosphorus from an unfiltered sample measures all forms of phosphorus in a sample, including dissolved and suspended orthophosphate, condensed phosphate, and organic phosphate; whereas, total phosphorus measured from a filtered sample measures the fraction of the total phosphorus which is in solution and not attached to suspended particles (U.S. Environmental Protection Agency, 2006).

\section{Trace Elements}

The term "trace" is a commonly used term for substances that regularly occur in concentrations less than $1 \mathrm{mg} / \mathrm{L}$ and typically include metals as well as radioactive elements and organic compounds. Within the context of this report, "trace elements" refers to metals and includes iron and manganese, though these constituents are often considered major elements. Many trace elements (for example, cobalt, copper, iron, manganese, molybdenum, selenium, and zinc) are essential elements required, in small quantities, for plant and animal 
metabolism (Hem, 1989). However, most trace elements in large concentrations can be harmful to plants and animals and even humans. Both natural (erosion and dissolution of elements from source rocks) and anthropogenic sources (fossil fuel combustion, industrial and municipal wastewater releases, urban and agricultural runoff, solid waste landfills, atmospheric deposition, and mining) contribute trace elements to the water.

Aluminum toxicity to aquatic organisms varies depending on its speciation and the life stage of the exposed organisms, and it is considered most toxic in its unstable monomeric form, which occurs in acidic streams with low $\mathrm{pH}$ (Giller and Malmqvist, 1998; Baker, 1982). Aluminum can bioaccumulate in fish, and effects of high doses of aluminum can affect metabolism, cell growth, and respiration (Moiseenko and others, 2005). Chronic toxicity information on beryllium is generally lacking in comparison to other metals toxicity data; however, a study by Hsieh and others (2003) using a Microtox chronic toxicity test showed beryllium as the most toxic out of 13 high-priority pollutant metals. Toxicity in this test indicated lowest observable effects concentration (LOEC) ranging from 0.742 to $1.49 \mu \mathrm{g} / \mathrm{L}$ for the Vibrio fisheri test species. In contrast, USEPA's acute toxicity value for beryllium, based on a $24-96$ hour test, was $2,500 \mu \mathrm{g} / \mathrm{L}$. Another study suggested that toxicity of beryllium on fish in acidic waters is comparable to aluminum and that beryllium may be an important unrecognized contaminant in acidified waters (Jagoe and others, 1993). High concentrations of cadmium can be toxic and can bioaccumulate in fish depending on the calcium carbonate concentration in the water (Moiseenko and others, 2005). Cadmium toxicity varies on the basis of the amount of free cadmium ions available, the concentrations of other metals and ions, and the fish species present (Hem, 1989; Sunda and others, 1978). Though copper also is one of several essential elements required by aquatic organisms to support various life processes, high copper concentrations are toxic to fish; toxicity varies on the basis of concentrations of other metals and major ions in the water, the amount of free copper ions, and the fish species (Moiseenko and others, 2005; Hem, 1989; Sunda and others, 1978). Iron, along with other essential microelements, while functionally critical to live organisms, can be toxic to aquatic organisms in high environmental concentrations (Moiseenko and others, 2005). Iron's chemical behavior is strongly influenced by the $\mathrm{pH}$ and the oxidation capacity of the water and microbial processes. Similar to aluminum, iron particulates are small enough to pass through a standard $0.45-\mu \mathrm{m}$ pore filter resulting in elevated "dissolved" concentrations that are actually partially composed of colloidal materials (Hem, 1989). Lead is toxic to aquatic life and humans and is known to accumulate in fish kidneys, liver, and muscles. Mercury is toxic and can bioaccumulate in aquatic organisms and humans (Moiseenko and others, 2005). Though industrial and commercial uses of mercury have been reduced since the 1970s, the volatility of mercury and its continued release through the burning of coal and other industrial processes has resulted in its being widely dispersed throughout the environment (Hem, 1989). Selenium, which can be released to water through irrigation return flow and coal-fired powerplants as well as from seleniferous shales and soils, has been shown to be acutely and chronically toxic to aquatic organisms, and controversy remains as to appropriate protective numeric criteria (Canton and Van Derveer, 1997). Selenium can affect fish populations by reducing reproductive success and can bioaccumulate and become toxic to adult fish, macroinvertebrates, and other aquatic life over time (Lemly, 1999). Excessive concentrations of strontium, which often accompanies calcium in the natural environment, has a high bioaccumulation capacity and can disturb bone tissue and disrupt metabolic processes involving the liver and blood (Moiseenko and others, 2005). Strontium, along with barium, is sometimes a marker for water produced from oil drilling (Mineral Information Institute, 2004). Zinc is an important mineral for plant and animal metabolism; however, in large concentrations it can be toxic to fish, and it is characterized by a synergistic effect resulting in increased toxicity when combined with copper (Moiseenko and others, 2005). Because of its relative abundance (about the same as copper or nickel) and its wide use in metallurgical processing of bronze and brass, for galvanizing steel, and in paints and rubber, zinc is widely dispersed in the environment $(\mathrm{Hem}$, 1989). Harmful effects on aquatic organisms from excess trace elements are variable and somewhat unpredictable, but at normal redox and $\mathrm{pH}$ conditions, most trace elements are adsorbed onto particulate matter, resulting in low dissolvedelement concentrations (Chapman, 1998).

\section{Solids (Suspended and Dissolved)}

Suspended solids are generally defined as the fraction that will not pass through a $0.45-\mu \mathrm{m}$ pore diameter filter; whereas, dissolved solids are defined as the fraction able to pass through a filter of that size. Turbidity and transparency in water are controlled by the type and concentrations of suspended materials, which can consist of variously sized silt, clay, microorganisms (for example, plankton), and inorganic and organic matter. Concentration of suspended solids can vary substantially with discharge. Dissolved solids and suspended solids correspond to filterable and nonfilterable residue, respectively. "Residue" applies to the weight of material (that is, solids) remaining following evaporation and oven drying of a water sample at a given temperature and is approximately equal to the total dissolved and suspended materials in water, recognizing that about one-half of the bicarbonate in the sample is transformed and volatilized as carbon dioxide (Chapman, 1998).

The results of these measurements are highly dependent upon the specific methods and drying temperature used due to variable volatility of organic and inorganic materials dissolved or suspended in water. Hem (1989, p. 156) indicates that the different drying temperatures, which typically are in the $103^{\circ} \mathrm{C}$ to $105^{\circ} \mathrm{C}$ or $180^{\circ} \mathrm{C}$ range, "do not produce 
significantly different results for most of the more dilute natural waters compared with other factors that may influence this determination." Dissolved solids also can be approximated by the sum of the dissolved concentrations of the major ions but is dependent on several assumptions and can result in a significantly different result than results obtained by residue left by evaporation methods; likewise, specific conductance also can provide an indication of the content of dissolved solids in water (Hem, 1989). Historical dissolved- and suspended-solids data without corresponding methodological information (unfortunately typical of these types of data) are of limited analytical utility and were only considered approximate when comparing sites and samples in this report.

Elevated suspended-solids concentrations can affect natural food production at concentrations of $250 \mathrm{mg} / \mathrm{L}$ and can interfere with reproduction of some fish at $500 \mathrm{mg} / \mathrm{L}$ (Johnson, 1985). Concentrations of dissolved solids greater than 2,000 $\mathrm{mg} / \mathrm{L}$ are known to adversely affect some sensitive fish species and younger stages of some fish species (Johnson, 1985; U.S. Environmental Protection Agency Office Of Water, 2004).

\section{Bacteriological Organisms}

While water quality is highly dependent on the purifying processes of many natural bacterial communities, some types of microorganisms are associated with human and animal waste and have been linked to human health problems; therefore, the risk of infection is increased to those who use contaminated water for drinking, food preparation, personal hygiene, and recreation. The survival of bacteria in water is dependent on the overall quality of the receiving water, including turbidity, oxygen concentrations, temperature, and nutrients. Once introduced into the water, some bacteria can adsorb onto clay, sand, and sediment, which can result in accumulation of bacteria in lakes and rivers. Bacterial counts and microbial source tracking for microorganisms of fecal origin (for example, Escherichia coli, the normal mammalian intestinal bacteria often used as an indicator organism, and other fecal coliforms such as fecal streptococci) are common practices to establish safe levels for various types of water use such as drinking or recreation and to evaluate and potentially reduce potential human and animal sources for the contamination. Natural surface waters, even in remote areas, may contain up to 100 organisms per $100 \mathrm{~mL}$, but ground water does not contain any fecal bacteria unless it is contaminated (Chapman, 1998). Additional microscopic particles of potential concern are viruses (for example, hepatitis) and other pathogens (for example, Salmonella); however, it is not common practice to test for these in waterquality monitoring programs, and no data for these other types of constituents were compiled as part of the data compilation effort for this report. Microbial testing for fecal bacteria is a sensitive technique subject to sample contamination and holding times, and enumeration of specific types of colonies is dependent on methodology. Positive results are an indicator of recent contamination, but the absence of organisms in a particular sample does not assure the absence of contamination (Chapman, 1998).

\section{Organic Compounds}

All natural waters contain some organic compounds; much of it is derived from living material undergoing natural processes (for example, plant photosynthesis and terrestrial organic matter transported to a water body), but some of it can derive from human sources such as wastewater. The amount of organic matter in water is typically small in comparison to dissolved inorganic constituent concentrations; however, even small amounts of organic materials can have significant effects on water's chemical behavior such as metals solubility, redox reactions, and microbiological behavior in the aquatic environment (Chapman, 1998). Organic compounds can be considered in terms of naturally occurring organic materials and synthetic organic compounds that are released through the waste streams into our environment, including wastewater-treatment effluent, industrial discharges, atmospheric deposition, agricultural and urban runoff, and septic systems. Concentrations of total organic compounds are typically approximated in terms of dissolved (DOC) and total organic carbon (TOC), though related field properties such as chemical oxygen demand (COD) or biological oxygen demand (BOD) also can be used as indicators of organic contamination above "natural" background levels (Chapman, 1998). Measuring DOC and (or) TOC is not frequent in most monitoring programs, and few water-quality monitoring programs analyze for synthetic organic compounds due to the difficulty of obtaining an uncontaminated sample and the expense of the analytical determinations.

\section{Radiological Constituents}

Naturally occurring and manmade radioactive constituents or radionuclides can be found in surface and ground waters and are derived from rocks and soil or from nuclear reactions that can release radioactivity into the environment. Radionuclides common in ground water include radon-222, radium-226, uranium-238, uranium-234 (from the uranium-238 decay series), and radium-228 (thorium-232 decay series). The occurrence and distribution of radionuclides in ground water is principally controlled by the surrounding geology, hydrogeology, and geochemical environment (Zapecza and Szabo, 1986). The effects of radiation on aquatic organisms, including increased mortality, genetic mutation, and reproductive loss, have been studied by many; radionuclides can accumulate in bottom sediments and remain dissolved in the water, both of which can be sources for bioaccumulation in aquatic organisms (Blaylock and others, 1993).

Measurements of radionuclides can be expressed in terms of specific nuclides as a rate of radioactive disintegration (for example, picocuries per liter, $\mathrm{pCi} / \mathrm{L}$ ) or in chemical units (micrograms or milligrams per liter). Alternatively they can be 
measured in more general terms such as total gross alpha or beta activity. Regardless of the type of measurement and units used for radionuclides, careful consideration of the censoring levels is warranted as results are commonly reported as nondetect and therefore do not provide adequate information to determine actual background levels (Hem, 1989), thus limiting the utility of these data.

Hem (1989) reported uranium measured in concentrations between 0.1 and $10 \mu \mathrm{g} / \mathrm{L}$ in natural waters (with concentrations greater than $10 \mathrm{mg} / \mathrm{L}$ in water associated with uraniumore deposits); uranium-238 is the predominant isotope of natural uranium and is considered weakly radioactive. Radium isotopes are strongly radioactive and detectable at trace concentrations; of these, radium-226 (disintegration product of thorium-238) and radium-228 (one of the disintegration products of thorium-232) are generally evaluated as a sum of the two in terms of water-quality standards. Typical concentrations of radium in most natural waters are less than uranium and generally less than $1.0 \mathrm{pCi} / \mathrm{L}$, though higher concentrations associated with deep aquifers or in areas affected by uranium and phosphate mining can occur. The effectiveness of the analytical procedures used to determine the amount of different radium isotopes present in water has historically favored measuring alpha-emitting particles such as radium-226 instead of beta-emitting particles such as radium-228 and did not always distinguish between radium isotopes and radon (Hem, 1989), which are considerations when evaluating historical data lacking specifics on analytical methodology.

\section{References Cited}

Baker, J.P., 1982, Aluminum toxicity to fish in acidic waters: Water, Air, and Soil Pollution, v. 18, no. 1-3, p. 289-309.

Blaylock, B.G., Frank, M.L., and O’Neal, B.R., 1993, Methodology for estimating radiation dose rates to freshwater biota exposed to radionuclides in the environment: U.S. Department of Energy, Office of Environmental Management, ES/ER/TM-78, 31 p.

Canton, S.P., and Van Derveer, W.D., 1997, Selenium toxicity to aquatic life-An argument for sediment-based water quality criteria: Environmental Toxicology and Chemistry, v. 16 , no. 6 , p. 1255-1259.

Chapman, Deborah, ed., 1998, Water quality assessments-A guide to the use of biota, sediments and water in environmental monitoring ( $2 \mathrm{~d}$ ed.): New York, E \& FN Spon, $626 \mathrm{p}$.
Freshwater Workgroup Subcommittee, 2002, Recommendations for core water-quality monitoring parameters and other key elements of the NPS Vital Signs Program water-quality monitoring component: National Park Service, Fort Collins, Colorado, 19 p., accessed April 10, 2007, at URL www.nature.nps.gov/water/Vital_Signs_ Guidance/Guidance_Documents/COREparamFINwSIGpg. $p d f$

Giller, P.S., and Malmqvist, B., 1998, The biology of streams and rivers: New York, Oxford University Press, 296 p.

Hem, J.D., 1989, Study and interpretation of the chemical characteristics of natural water ( $3 \mathrm{~d}$ ed.): U.S. Geological Survey Water-Supply Paper 2254, 263 p.

Hsieh, Chi-Ying, Tsai, M., Ryan, D.K., and Pancorbo, O.C., 2003, Toxicity of the 13 priority pollutant metals to Vibrio fisheri in the Microtox ${ }^{\circledR}$ chronic toxicity test: The Science of the Total Environment, v. 320, p. 37-50.

Jagoe, C.H., Matey, V.E., Haines, T.A., and Komov, V.T., 1993, Effect of beryllium on fish in acid water is analogous to aluminum toxicity: Aquatic Toxicology, v. 24, no. 3-4, p. 241-256.

Jeffries, D.S., Wales, D.L., Kelso, J.R.M., and Linthurst, R.A., 1986, Regional chemical characteristics of lakes in North America: Part I-Eastern Canada: Water, Air, and Soil Pollution, v. 31, no. 3-4, p. 555-567.

Johnson, S.K., 1985, Understanding water analysis reportsWater from freshwater fish ponds and their water supplies: Proceedings of the 1985 Texas Fish Farming Conference, College Station, Texas, January 23-24, 1985.

Lazorchak, J.M., Herlihy, A.T., Rosenbaum, B., Haggerty, P., Klemm, D.J., and Green, J.H., 2000, Assessing stream vulnerability to mine drainage and acid deposition in the midatlantic by mapping probability sample data from EMAP and the National Stream Survey, in Scientist to Scientist Meeting, meeting handouts, National Exposure Research Laboratory, Las Vegas, Nevada, June 14-15, 2000, accessed August 18, 2008, at URL http://www.epa.gov/ hardrockmining/scitosci/scietoscie.htm

Lemly, D.A., 1999, Selenium impacts on fish-An insidious time bomb: Human and Ecological Risk Assessment, v. 5, no. 6, p. 1139-1151.

Mineral Information Institute, 2004, Barite: Mineral Information Institute, Golden, Colorado, accessed March 17, 2006, at URL http://www.mii.org/Minerals/photobarium.html

Moiseenko, T.I., Kudryavtseva, L.P., and Gashkina, N.A., 2005, Assessment of the geochemical background and anthropogenic load by bioaccumulation of microelements in fish: Water Resources, v. 32, no. 6, p. 640-652. 
Murphy, Sheila, 2005, General information on pH: Boulder Area Sustainability Information Network, accessed on March 17, 2006, at URL http://bcn.boulder.co.us/basin/ data/BACT/info/pH.html

Rounds, S.A., July 2006, Alkalinity and acid neutralizing capacity (version 3.0): U.S. Geological Survey Techniques of Water-Resources Investigations, book 9, chap. A6, section 6.6, accessed April 10, 2007, from http://pubs.water. usgs.gov/twri9A6/

Sunda, W.G., Engel, D.W., and Thuotte, R.M., 1978, Effect of chemical speciation of cadmium to grass shrimp, Palaemonetes pugio-Importance of free cadmium ion: Environmental Science and Technology, v. 12, no. 4, p. 409-413.

U.S. Environmental Protection Agency, 1999, EPA guidance manual, turbidity provisions, accessed January 13, 2006, at URL http://www.epa.gov/safewater/mdbp/mdbptg. html\#turbidity

U.S. Environmental Protection Agency, 2002, Ecoregional criteria, accessed November 10, 2008, at URL http://www. epa.gov/waterscience/criteria/nutrient/ecoregions/

U.S. Environmental Protection Agency, 2006, Volunteer stream monitoring-A methods manual, chapter 5, 5.6 Phosphorus: U.S. Environmental Protection Agency Office of Wetlands, Oceans, and Watersheds, Monitoring and Assessing Water Quality, accessed April 27, 2007, at URL http://www.epa.gov/volunteer/stream/vms56.html

U.S. Environmental Protection Agency Office of Water, 2004, 2004 Edition of the drinking-water standards and health advisories: U.S. Environmental Protection Agency Office of Water EPA 822-R-04-005, 12 p.

Zapecza, O.S., and Szabo, Z., 1986, Natural radioactivity in ground water-A review, in National water summary 1986 - Ground-water quality: U.S. Geological Survey WaterSupply Paper 2325, p. 50-57. 
Publishing support provided by:

Denver Publishing Service Center

For more information concerning this publication, contact: Director, USGS Colorado Water Science Center

Box 25046, Mail Stop 415

Denver, CO 80225

(303) 236-4882

Approved on July 18, 2008

Or visit the Colorado Water Science Center Web site at: http://co.water.usgs.gov/ 
